

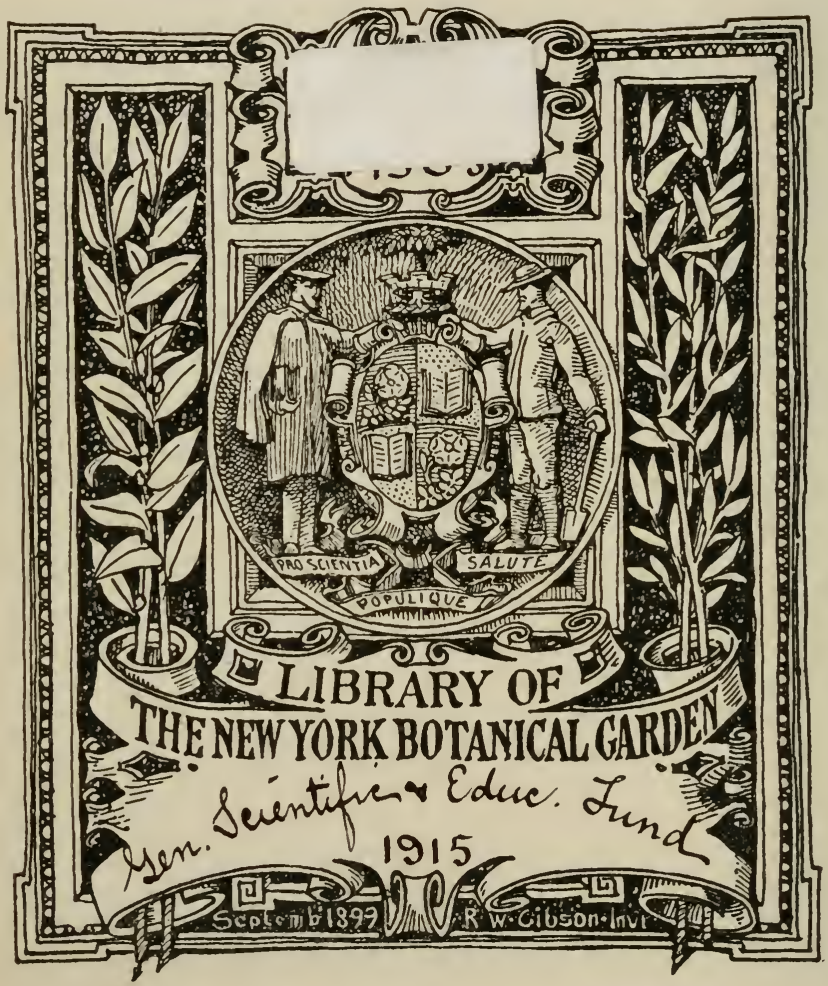






\title{
THE
}

\section{NATURAL PRODUCTIONS OF BURMAH,}

\author{
ok
}

\section{NOTES}

ON THE

\section{FAUNA, FLORA, AND MINERALS}

OF

\section{THE TENASSERIM PROVINCES,}

\author{
A.ND
}

THE BURMAN EMPIRE.

BY

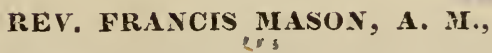

COKKESPONDING MEMBER OF THE BOSTON SOCIETY OF NATURAL HIETORY, AND OF THE LYCEUM OF NATURAL HISTORY, NEW YORK.

\section{A U L M A I N :}

A MERICAN MISSION PRESS.

THOZ. S. RANNEY.

1850. 



\section{P R E F A C E.}

This work owes its origin to the wants experienced by a translator of the Bible.

Ever since the day that man was sent to dress the garden of Eden, and to give " names to all cattle, and to the fowl of the air, and to every beast of the field," he has in every age, and in every clime, been a lover of nature. It has been remarked of the Hebrews especially, - that "they make such frequent recurrence for metaphorical expressions to natural objects, and particularly to plants and trees, that their poetry may almost be termed the botanical poetry." The Hebrew and Greek 'Testaments contain between seven and eight hundred names of natural productions, found in the countries where the books were written; and Michaelis says "there are upwards of two hundred and fifty botanical terms." These names, and terms enter into many thousands of verses, THE PROPER RENDERING OF WHICH DETENDS UPON A CORRECT, KNOWLEDGe OF THE THINGS DESignatf. And how much thore lucid and interesting will appear the Book of God, if these terms be rightly translated!

'Throughout the inspired writings of the Ancient Scriptures, and in all the teachings of the Apostles, we find constant allusion to the works of nature. And our Saviour in his parables and similitudes continually draws fron the natural scenes of earth which his almighty hand had fashioned, that "the invisible things of Him from the creation of the world might be clearly seen, being Inderstood by the things that are made." But had his hearers been unacquainted with the partiLn cular names and properties of the plants or animals to which he referred, they could never liave felt as they did, the overwhelming power of his arguments and illustrations. And yet, by some translaturs, a very considerable propor- 
tion of the botanical, and zoological names that occur in the Bible are unnecessarily transferred! "Not being a zoologist, botanist, or mineralogist," wrote a distinguished translator, "I have not unfrequently, in disposing of technical terms whose meaning I could not satisfactorily settle, gone the whole animal, plant, or mineral, as the case might be, and transferred it."

In this way many words are transferred for which there are good veruacular names, and a native has in his Bible a barbarous word that conveys no idea, while it may be the original designates a flower, that is wafting its fragrance within the lattice where he sits reading. This is no fancy sketch. The camphire of the English Bible, the exquisitely fragrant Lawsonia inermis, or henna, is rendered in one Indian version by camphor, and in another the name is transferred, while the shrub itself is growing by the doors of myriads of native houses in both Indias, and for which there are established vernacular names in every Indian language to which I can refer.

Such transfers always cast a deep shadow over the sig. nification of the passage in which they occur, and sometimes wrap it in impenetrable darkness. For instance; Christ says to the Scribes and Pharisees : "Ye pay tithe of mint and anise and cummin, and have omitted the weightier matters of the law, judgment, mercy and faith." Here the antithesis can only be seen by a knowledge of the trifling character of mint, anise, and cummin; yet in two Indian versions every one of these names is transferred, which renders the clause, without a paraphrase, as unintelligible as the English Bible would be with as many Choctaw words in their place. Still, nothing could be more unnecessary, for the readers of the versions are nearly as familiar with mint, anise, and cummin, as the people of Europe, and have as well established names for them in their language.

In two versions, made several thousand miles apart, the translators, transferred the original word for wocd-aloes, although the people for whom they wrote were well acquainted with it, and there were good terms in the languages in which they were translating by which to render 
the word, but of both facts the translators were manifestly ignorant.

These examples, which might be easily multiplied, illustrate the advantages which a translator with some knowledge of the natural sciences, possesses in dealing with the Word of God. But the reader asks, "why need he enter scientifically into these studies? Why does he not take the lexicons, and other helps prepared for him ?"

Many are the admirers of nature, but let it not be supposed that all are her observing students. The pages of learned men in Europe and America, who have incidentally written upon natural history, prove that they are not.

Rosenmuller is the author of the best work extant on the botany of the Bible, yet his unskillful treatment of the subject sufficiently attests his slight knowledge of the science. His descriptions are usually ill written, and bring before the eye of the reader no definite picture. They are often moreover very defective, giving popular names, as beans and lentils, which are indefinite and applicable to different species and even to different genera, without the systematic names, which alone are determinate and enable a translator to render accurately. Occasionally his statements are erroneous. Of agallochum or wood-aloes he says:" T'here is a species of this tree that grows in the Moluccas, called garo, Linnæus has described it as Exocaria agallocha." It would perhaps be difficult to find two trees in the whole regetable kingdom with more opposite properties, than these two species. The Burmese are well aquanted with both. Mr. O'Riley observed correctly that, "Akyau is a very fragrant, and a very scarce wood of high value with the natives." This is agallochum or wood-aloes." 'The other is a tree that the Burmese call $t a-y a u,+$ abundant near the sea, the juice of which is said to produce the most intense pain, and often blindness if it enters the eye. From its power to produce blindness the Karens call it the "blind tree;" and the natives are all of them so 
much afraid of it, that $I$ have sometimes found it difficuls to induce my boatmen to pull up beneath its shade.

In Carpenter's Natural History of the Bible, a popular English work, reprinted by Abbott in America, a description of the gecko is given worthy of the days of King Arthur. "It is thus described," says the author, "by Cepede: 'Of all the oviparous quadrupeds whose history we are publishing, this is the first that contains a deadly poison. This deadly lizard, which deserves all our attention by his dangerous properties, has some resemblance to the chameleon. The name gecko, imitates the cry of this animal, which is heard especially before rain. It is found in Egypt, India, Amboyna, \&ce. It iuhabits by choice the crannies of half rotton trees, as well as humid places. It is sometimes met with in houses, where it occasions great alarm, and where every exertion is used to destroy it speedily. Bontius states, that its bite is so venomous, that if the part bitten be not cut away or burned, death ensues in a few hours."

It is well known in India that the gecko is as harmless as the cricket. I have had them drop from the ceiling upon my naked hand, and hang suspended by the feet from my fingers without the slightest pain or inflammation ensuing.

Stuart on Rev. 21: 18, says: "The bottom row of foundation stones was jaspcr-which is of a green transparent colour, streaked with red reins." Such a definition of jasper I have never been able to find in any work on mineralogy; and Webster, following Dana defines it: "An opake impure variety of quartz, of red, yellow, and also of some dull colours." T'he distinctive character of jasper from other minerals that resemble it, is "its opacity." The Greek word as used by the Apostle, undoubtedly designated the stone now called heliotrope or blood-stone-a mineral of a remarkably deep, rich, green; and translucent, but spotted with opake red spots, supposed to be red jasper. There is in it something peculiarly agreeable to the eye above all other precious stones I ever saw, or that probably exist; and were heliotrope inserted in the version; the imagination of ev- 
ery reader would picture to himself a foundation for the Ileavenly Jerusalem of the pleasantest stone for the cye to gaze upon, that earth can produce.

Murray, in his Encyclopedia of Geograpliy, the first work of its class, says: "To the fig tribe belongs the famous banyan of Inciia, commonly called peepul tree, and constantly planted about Hindoo temples ( Ficus retigiosa. h" But the famous banyan is not commonly called peepul, but bir; and the peepul is not the banyan, and the tree which is usually planted about Hindu temples is not the banyan, but the peepul, and the banyan is not Ficus religiosa, but Ficus indicus. Again, he remarks : "Far superior to this [the cocoa] in the magnitude of its leaves, of which a single one will shelter twelve men, is the palmyra palm (Borassus flabelliformis,) which sometimes attains to one hundred feet, while its trunk yields abundantly toddy or palm wine."

It is true the palmyra produces toddy, not however from the trunk, but from the spathes that bear the flowers and fruit, but the leaf of the palmyra is not much larger than a large cabbage leaf, and the reference to the leaf should have been to the great fan palm of CeyIon, Corypha umbraculifera, a palm not of the same genus with the palmyra.

In a little work published by the American 'Tract Society, it is written: "In some hot countries where water is scarce, travellers obtain a supply from the palm tree;" and the statement is illustrated by a very good representation of the common plantain tree, with a fine stream of water gushing from an incision that has been made in the trunk!

The writer had probably some confused ideas of the palm producing toddy, or the traveller's tree, handsome urania, which produces water when a leaf is broken off; or of the water-vine, pliytocrene, an immense creeper that grows on our thirsty mountain sides, which when dissevered discharges a large quantity of water, that is a most grateful beverage in a hot day, when far above the streams of the vallies. 
In one of the elaborate volumes of the United States Exploring Expedition it is said: "In its wild state the peacock is peculiar to Hindustan ;" while they are roving wild all over these Provinces, Arracan, and the Burman Empire. Webster, defines dammer as "a resinous substance, obtained from a species of agathis or dammara, a tree allied to the pines," while here it is obtained from the wood.oil tree family; ${ }^{*}$ and a considerable proportion of what Europeans often call dammer, is a hard kind of bees' wax, produced by a bee that builds in hollow trees.t

With teachers like these Europeans and Americans come to India, and find themselves in the midst of a fauna and flora with which they are utterly uracquainted. In sections where there are lexicons that define correctly the vernacular names, the difficulty is scarcely felt. In Wilson's Sanscrit Dictionary, for instance, the systematic name of nearly every plant and animal known to the language, can be found at once; but if, as in Farther India, the lexicographers are as much in the dark as the inquirer who consults them, he has no alternative but to remain in darkness, or sit down to the patient study of the objects themselves. And to this toil the translator of the Scriptures must address himself, for it is not optional with him, but is a part of his professional duty to render, if possible, every word of the original by its corresponding word in the vernacular, and he is so far wanting in the trust committed to him by the churches or societies whose ambassador he is, if he shrinks from any study requisite to qualify him for the accurate performance of his work.

In ordinary circumstances, the professional duties of most men preclude them from testowing the time and attention to the natural sciences, necessary to enable them to determine accurately the character of the objects of nature with which they are unacquainted. It is not remarkable then that our Chin-Indian literature abounds in errors. Throughout India, wherever there is European society, there is found a numerous class of English names incorrectly applied to Indian productions, which almost unavoid-

$$
\text { * अर्ठे" }
$$


ably lead the translator, or author astray, when unable to make a scientific examination for himself: On this Coast, for instance, it has passed from conversation to books, published within the last ten years, that turmeric is saffron; the flower of the thorn-apple, the trumpet flower; the tamarind tree, the tamarisk, and its timber, iron wood; the ebony tree is the cabbage tree of one author, and the fig tree of another; while ebony not being supposed to exist, though abundant throughout the Provinces, is defined " a kind of a tree." The fennel flower is " a kind of rice ;" nettles, " a kind of thorn;" sweet flag, sugar cane; and the date tree is the palmyra palm. Mica is talc ; serpentine, jasper ; the carnelian, a garnet or ruby ; gambore, realgar the red sulphuret of arsenic; natron, the carbonate of soda, is saltpetre the nitrate of potash; and antimony is bismuth, according to one authority, and James' powder, according to another. The porcupine is a hedge-hog; the hedge-hog, a pangolin: the shrew-mouse a musk-rat; the sand-badger or arctonix, a hyena; barking deer, porcine deer; the monitor, a guana; and the blood-sucker, a chameleon. The adjutant is a gull; the eagle, a swan; the hornbill, a crane; the sun-bird, a skylark; and the grey heron, a water-hen.

In a work translated from the Burmese into English, and printed at the expense of Government, the Burmese name of the common wild ox, Bos sondaicus, is translated bison; the sambur, or rusa deer, is elk; barking deer, spotted deer; the eagle is an adjutant; cranes are called cyrusses; sun-birds, hnan-sok; a coluber is translated a leng snake; a crocodile, an alligator ; the toad, " a rough frog ;" tin in one place is lead; and pewter, or a mixed metal resembling it, is translated " white copper ;" the Bengal quince is rendered okshect; one species of millet, sap; another species of millet, barley; barley is translated mayau, in one place, and mace in another; arum is "ping (root)," a species of yam, thade; and the corypha palm, the palmyra palm.

This last error may be supposed to be of little consequence, and yet through it, the whole paragraph in which it occurs becomes false; and illustrates a precisely opposite 
argument from that for which it is brought. The author is made to say: "As regards the inheritance like a palmyra tree; it is the nature of this tree not to grow from cuttings or shoots; having lived its time, it flowers and bears fruit; when the fruit has fallen off, the parent tree dies; after its death, each fruit becomes a tree and continues the family. Whilst the tree was alive, no other tree could be produced; so only on the death of their parents do children inherit." The palmyra tree produces its fruit annually, as regularly as the apple tree, and young trees may be raised from it as easily as from apple seeds, while the parent tree is still living; so if the comparison prove any thing, it proves that children may inherit before the death of the parent, just the converse of that for which the comparison was made. Let; however, the original word be correctly translated, and no simile can be more striking, and appropriate. A corypha palm after it has borne fruit, lifts its blackened leafless head above all the other trees of the forest, like the dead father of the woods struck by lightning.

Where two or more systematic names are attached to an article in this work, they are, unless the contrary be indicated, the different names by which the same object is designated by different writers. In zuology these synonymes have been selected principally from articles published in the Journal of the $\Lambda$ siatic Society, by Dr. Cantor and Mr. Blyth. In botany the first name is the one under which the article will be found in Voigt's Catalogue, if in that work, and in other moderi writers; while the second is the Limnaan name, or the one by which it was described by Roxburgh and by other anthors of the old school.

The utility of these synonymes will be best understood by an example. Gesenius, Rosenmuller, Harris, and other Biblical writers, tell their readers that copher designates Lavsonia inermis; and $\mathrm{Dr}$. Wight in his Illustrations of Indian Botany, gives a handsome coloured figure of Lawsonia alba. To a person not read in botany these wil! be regarded as different species, but on turning to my 
article, the reader will learn at a glance, that they are different names given by different writers to the same plant. 'Thus it will be seen that our common barking deer lies scattered over the pages of natural history under twelve different names, and without the synonymes it might be taken for twelve different species. In like manner, when objects have several native names, as they often have, I give all that I have beard.

Still the investigator will not always obtain at once the object he seeks from the native name; and this is a difficulty which no author can obviate, as it exists in the language. Different objects sometimes have the same name, as for instance, the goat-sucker and the snipe. 'The Burmese call both mye-vote, ${ }^{*}$ from their habit of dwelling on the earth. Sometimes a slight distinction is supposed to exist between different things, which is not always observed. The Amherstia and the Jonesia are both athauka trees, but the Amherstia is regarded as the female, and the Jonesia as the male tree, which is therefore denominated athauka-pho.t So the male of the fagræa, is the gordonia, or anan-pho.t The same object is often known by different names. Our knowledge of the existence of platina in Burmah was first furnished by Mr. Lane, who said the Burmese called it sheen-than, but in his Dictionary he defines it shwe-phu, or white gold. Some persons make distinctions which others neglect. 'The water-lily and the nelumbium are both call kya; the kya is restricted to the water-lilies, and the nelumbium called pa-dung-ma. Add to which, for many obscure species in every department of the natural kingdom, the natives have no definite names, on which they can agree among themselves.

$$
\text { * 6दु० of" † † }
$$

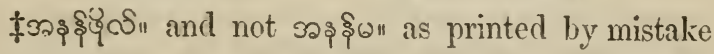
on page 70 .

ईहुำ

||mip"

पाu९g०" 
The local names used in Tavoy and Arracan are given where known; the latter on the authority of Capt. Phayre; from whom also were first derived some of the Burmese names for birds, and the smaller mammalia. It is only within the last two years that the proper Burman name for eagle has found its way into books, though it was communicated first by Capt. Phayre, some eight or ten years ago.

The present work does not explain mere technicalities for the naturalist, but brings to light in the department in which it enters, a host of common English words that have hitherto been left, in this country, like uselesss lumber in the shade. To illustrate this position, take a single example from the ichthyology, in which for the first time the correct native names are furnished of the following fish known to English readers: River perch, cockup, band fish, umber or sea perch, Inäian whiting, mullet,* mango-fish, climbing perch, snake-head, ophidian, longsnout, doree, pomphret, ribband-fish, goby, carp, barbel, gudgeon, bream, white fish, loach, flat-bellied herring, thryssa-anchovy, bristle-finned sprat, freslı-water herring, flying-fish, gar-fish, half-billed gar-fish, plagusia-sole, brachirus-turbot, adipose cat-fish, short-headed cat-fish, eight barbuled cat-fish, long-finned cat-fish, two barbuled cat-fish, fork-tailed cat-fish, barbuleless cat-fish, plotosus cat-fish, clarias cat-fish, long-headed cat-fish, hammerheaded shark, saw-fish, scate or ray, sea-porcupine, or square fish, fishing frog, common eel, serpent-hearted eel, and conger eel.

Still no pretensions are made in this work to completeness. It is not a book composed in the luxury of literary leisure, but a collection of notes which I have been making during the twenty years of my residence in this country, in the corners of my time that would otherwise have been wasted. Often to forget my weariness when travelling, where it has been necessary to bivouac in the jungles; while the Karens have been seeking fuel for their night fires, or angling for their suppers in the streams, I have occu-

-There are three species of mullet with three distinct native names, one of which has been correctly defined before. 
pied myself with analyzing the flowers that were blooming around my couch, or examining the fish that were caught; or an occasional reptile, insect, or bird that attracted my attention. Such occupations have brightened many a solitary hour ; and often has the most unpromising situation, proved most fruitful in interest; for "the barren heath, with its mosses, lichens, and insects, its stunted shrubs and pale flowers, becomes a paradise under the eye of observation; and to the genuine thinker, the sandy beach and the arid wild are fuil of wonders."

Without books and without means to convey away specimens, my plan was to note down just such characteristics in the objects that I observed, as secured most of $\mathrm{my}$ attention; but when I came to compare my notes with descriptions in books, they would often be found to contain insufficient data to determine the species, and sometimes even the genus, but perhaps enough for the tribe or family. In botany this was necessarily not unusual, because I frequently met with a plant in flower without the fruit, or in fruit without the flower; where both flower and fruit were necessary to determine the genus. Often again, never contemplating publication, when I had no use for the article in translation, and no object in being precise, I was content, as with fish for instance, to satisfy myself that it was a cat-fish, a member of the carp family, or an eel as the case might be, without making observations which would enable me to distinguish the species.

These notes would probably have remained in manuscript, as they have done for many years, had it not been for the liberal patronage of our Commissioner Major Bogle, and a few other kind friends who interested themselves in their publication; the former subscribing for fifty copies, and the latter for proportionately large numbers.

Future investigation will supply many deficiences, and correct many errors that are inseparable from a first attempt like the present, which involves the observation of so many objects, in so many different departments of natural science, and their names in so many languages. Still, it is confidently believed, that no one can longer say of Farther India, as does Murray in his Encyclopedia 
of Geography : "There are no materials on which we can attempt a botanical, or geological delineation of this territory. 'The zoology also of these immense and luxuriant regions is scarcely known."

It will therefore be seen that a work of this kind was demanded, and I trust it will commend itself not only to the Biblical student, but to authors in the vernacular languages, especially to such as shall hereafter prepare native works on natural history. It will also be serviceable to those who translate from the Burmese or Karen into English, and to all natives who read English, and particularly to every one who desires to write on these Provinces either in India, England, or America.

Such is my reply to those "machines for eating and drinking, digging and working, hoarding and spending," who ask: "WIAT's THE USE OF 1T? 'They cannot well see the use of studying the stars, observing the stratification of rocks, or being curious about shells, minerals, and plants, birds, beasts and insects." 


\section{INTRODUCTION.}

\section{NATURALSCENERY.}

- Fern, flowers, and grasses creep.

Fentastically tangled : the green paths

Are clothed with early blossoms, through the gras

The quick eyed lizard rustles, and the bills

Of summer birds sing welcome as ye pass;

Flowers fresh in hue, and many in their class,

Implore the pausing step, and with their dyes,

Dance in the soft breeze in a fairy mass;

At every door the odorons jasmines rise.

Kissed by the breath of heaven, seeve fragrant from the skies." - Byrar.

"It is a beautiful country," wrote one of our Bengal visitors : " here, there are views and patches of scenery, green fields and green lanes that lead back the mind to one's own loved land." No contrast can be more striking than the scenery of the Salwen, and that of the Hoogly, the last often that the eye rests upon before reaching this coast. The interminable level plains of Bengal, without the semblance of a hill for hundreds of miles, are changed for mountains and valleys, cloud-capped crags, and frowning precipices; and green fields with immense grotesque masses of mural limestone starting up in their midst, like the gigantic spectres of an antediluvian world.-The dullest of all landscapes is exchanged for the most sublime and picturesque.

"It is a beautiful land" when seen on the coast, but it is still more beautiful when seen amid its mountain streams; streams that cannot be surpassed in romantic beauty, even in the annals of poetry itself. In some places they are seen leaping in cascades over precipices from fifty to one hundred feet high; in others, spreading out into deep, quiet lakes. In some places, they run purling over pebbles of milk-white quartz, or grass-green prase, or yellow jasper, or sky-blue slate, or variegated porphyry ; in others, they glide like arrows over rounded masses of granite, or smooth angular pieces of green stone. In some places, nought can be heard but the stunning sounds of "deep calling unto deep ;" in others, the mind is led to musing by the quiet murmur of the brook, that falls upon 
the ear, like distant music. The traveller's path often Ieads up the middle of one of these streams, and every turn, like a turn in the kaleidescope, reveals something new and pleasing to the eye. Here, a daisy-like flower nods over the margin, as if to look at her modest face in the reflecting waters; there, the lotus-leafed wild arum stands knee deep in water, shaking around with the motion of the stream, the dew drops on its peltate bosom, like drops of glittering quicksilver. Here, the bare fantastic rocts of a willow, sprinkled with its woolly capsules, come down to the water's edge, or it may be an eugenia tree, with its fragranc white corymbs, or a water dillenia, with its brick-red scaly trunk, and green, apple-like fruit, occupies its place; there, the long drooping red tassels of the barringtonia hang far over the bank, dropping its blossoms on the water, food for numerous members of the Carp family congregated below. On the islets are seen a dwarf species of wild fig, and the bare rocks on which vegetation has not yet squatted are often the watch-tower of the king-fisher, with her wings of blue, and breast of red. Now we come on a little patch of impenetrable reeds, a Mississippian cane brake in miniature; and anon the pink corymbs of a shrubby species of Ixora looks down upon us from a steep bank. In place of the reed, we have sometimes a thicket of the curious half-anthered Phrynium, and instead of the Ixora, we have often large clusters of a fragrant clerodendron, of which our forests produce three or four different species. Often the waters breathe the odor of the lily from the water Crinums that float their large blossoms on the surface, while on the margin, the glowing red flowers of the amonum peep up from the base of their green stems ; or a creeping species of acacia entwines its globular scentless flowers with the fragrant one sided spikes of the Hopea, high in the lofty tree tops. Here an ebony tree droops beneath the weight of its persimmon-like fruit, and there a gamboge tree lifts its graceful head, with its delicate little mangosteens in miniature; or the large creeping oleastor swings from the forest tree to which it clings its rich bunches of sour scarlet plums.

Some pages in our natural scenery are quite unique. Take one for illustration, that is constantly open before the face of Maulmain. 


\section{THE NATURAL FORTRESS OF DODNGYANG.}

On looking abroad from the pagodahills of Maulmain, an unbroken range of primitive mountains, four or five thousand feet high, are seen on the margin of the eastern horizon, sweeping around to the north west like an amphitheatre, where they are lost in the misty distance. From Martaban Point another range extends directly north, parallel with the west bank of the Salwen. In the space between these mountains, bounded by the Salwen river on the west, and the Gyaing on the south and east, is an immense alluvial plain, resembling the prairielands of Illinois and Missouri. In the midst of this plain, twenty miles north of Maulmain, and six or eight east of the Salwen, the attention of the spectator is arrested by a pile of the most picturesque mountain limestone that ever adorned a landscape. Rising abruptly, in the most fantastic shapes, from the level of tide-water to nodding precipices two thousand feet high at a single leap, they seem to shake their hoary-lichen faces and fern-fringed foreheads at the passing traveller, and threaten him with instarit destruction. The whole range is not more than eight miles long, and at twenty miles distance its numerous grotesque peaks give it no very dissimilar resem. blance to a Gothic cathedral ; and the illusion is made the more real by the spire of a small white pagoda being distinguished with some difficulty in the distance, on the very top. most summit of the highest point of the range, and on the margin of an abrupt precipice.

On a near approach the range loses the continuous appear. ance which it possesses in the distance, and assumes an undulating aspect, like the waves of an angry ocean. A precipice, near two thousand feet high on the north westextremity, sinks to the south east to within a short distance from the ground, then rises abruptly again to nearly its former height, presenting an unbroken precipitous front for three or four miles. In one place the precipice is not more than five or six hundred feet high, and at this spot a cool crystal stream, several yards wide, and two or three feet deep, gushes out of a purple grot at the base A writer in the Maulmain Chronicle, describing this stream several years ago, remarked, "It was in the hottest part of the year that I went to the spot, accompanied by several Karens 
The heat at the time was truly oppressive until we came within thirty or forty rods of the mountain, when the temperature very sensibly changed, and a delightfully cool current of air was felt setting from the mountain. As we advanced, we saw quite a large stream of water issuing from a cavity in the perpendicular rocks which rose above us to a great height. 'This stream was clear as crystal and cold as ice water. The temperature of the air here forcibly reminded me of a cool October day at home. On examination, I found the cold air proceeded from a variety of air holes on the side of the mountain. It was a luxury to see so clear a stream of water after having for a long time seen only the muddy waters of the river. It was a luxury to taste water which so exactly resembled the cold wells at home. It was also a luxury to find a little spot in the hottest season and the hottest part of the day, which defied the scorching rays of a vertical sun, and made one fancy that he had been transported to his own climate and was breathing his own pure air.'

This writer's emotions would have chastened had he known that that stream, "clear as crystal and cold as ice water," had been the theatre of more agonizing sceues than the muddiest and hottest stream in the Provinces; scenes that had won for it the name of "TeErang" - the Brook of Weeping.

With some difficulty a man may enter the cave and follow up the stream a few yards, but the only path is the bed of the brook, and the glittering stalactites hang so low from the roof that a passage is not easy. A more in eresting scene awaits the lover of nature without. Immediately above the mouth of this cave and stream the rocks rise as abruptly as in any other locality, but the limestone has been worn by the waters of ages nuequally, and many masses of rock have been detaclied from its face and fallen to the base, leaving numerous jutting prominences, some of which are loosely held by the arms of the parasitical Ficus, whose roots find a passage into every crevice, and often bind together the broken fragments. With a steady head, and with fingers and toes accustomed to climbing, a person, by pursuing a zigzag course, may reach the summit at this point. 'The fallen rocks piled up from the base, afford a very practicable flight of steps above the lighest tops of the gorgeous red-flowered Coral trees, that throw their shadow 
over the mouth of the cave, and crowd the banks of the brook. Above, the precipice has a slight declination, and a rough, uneven surface, so that naked feet and hands with care may ascend it to a narrow ledge, and this ledge, though in some places less than the width of a man's foot, serves as a path to a natural parapet, in which one armed man might conceal himself and defend the ascent against an army. By a path with like various alternations the margin of the summit is reached, where a full view of the region below is spread out before the eye of the spectator. At the base of the western mountains the Salwen is seen plunging down its mighty waters to Martaban and Maulmain, where they are joined by the Gyaing, that bounds the prospect on the south and east; while little islands of forest trees, each concealing beneath its sharle a quiet hamlet, dimple the whole plain; and babbling brooks thread their wandering ways like veins of silver, or mark the courses of their hidden waters by the emerald hue of their banks.

Turning from the prospect below, and climbing upward on men's shoulders, a gap in the rocks above is reached; then descending a few yards, the spectator is astonished to fincl himself on the edge of a large basin, like the crater of an extinct volcano. Around, and beyond, on the opposite side of the gulph, for miles in extent, dark precipitous crays, of every imaginable and unimaginable form, fling down their tall shadows a thousand feet about the place of entrance, enclosing an area of several square miles.

"It was a tranquil spot, that seemed to smil?

Even in the lap of horror ; ficus clasped

The fissured stones with its entwining feet,

And did embower with leaves for ever green,

And berries dark the smooth and cup-like space

Of its inviolated floor-'tis the haunt

Of every gentle wind whose breath can teach

The wilds to love tranquility."

Down a steep descent of one or two hundred feet, an uneven plain is reached, covered with a luxuriant forest. This impregnable natural fortress has been a place of refuge for the Karens during many generations. While the Burmans, the Siamese, and Talaings, were contending in the plains below, the Karens, in this eyrie home, peeped out on the belligerents from behind their battlements in perfect security; 
for besides the place where I ascended, there is only one other possible place of ascent, and that still more difficult, so that half a dozen men could always defend it from any force that could be brought against it. The Karen guide said that none but Karens had ever before ascended the precipice, or entered within its precincts. Indeed, that there was here one of the largest, strongest, and most remarkable castles that nature ever built, had never been imagined. Its chief weakness is the lack of water, yet it is far from being wholly destitute of that. A bout a mile from the entrance, a gradual ascent of an hundred feet leads to the summit of a precipitous glen, and on des. cending it about two hundred feet by natural steps in the craggy rocks, a small stream of water is seen gushing from the face of a precipice, which the guide said he thuught resembled the rock struck by Moses in the Arabian desert. This affords a never failing supply of several quarts, and sometimes gallons of pure water, every hour in the year; but as this is the only spring as yet discovered, the place does not afford a sufficient supply for a large body of people. The arts of civilization could, however, overcome this difficulty by sinking a shaft to the subterranean brook that flows out beneath.

In the days of the Burman emperor Alompra, before his successes in these provinces, a large number of Karens were besieged here by the Siamese, and tradition says that nearly the whole perished for the want of food and water. From the sufferings of that period, or a previous one, the place has ac. quired the naine of "Dōngyans" - the Weeping City.

The whole range is named "Zwa-kabin,"-the Mooring of the Ship, from a tradition, which says that in ancient times the whole world was covered with water, and the only survivors of the human race were in a ship which floated hither, where the highest point of the range, being above water, the ship was moored to it.

Since the reign of Alompra, the Karens seem to have made special efforts to plant fruit trees in this their last refuge from an invading army. Jack, and mango trees abound, arid pine apples are numerous. 'The opposite-leafed mango which bears a fruit like a plum, the Heritiera, whose agreeable sub-acid fruit is borne in bunches like large grapes, and the edible Zalaccâ, with its bunches of red echinated fruit, are also com- 
mon, and a few trees are seen of the Indian Sandoricum, which bears a fruit valued by the natives, as large as an apple, but internally more like a mangosteen, and is ofteu called by Europeaus the wild mangosteen. The Karens have also been mindful to make provision for their betel, an article regarded by them almost as essential as food. There are two species of areca-nuts, and the piper betel-vine is scattered every where.

They have also provided materials for mats, having planted in large quantities a species of Pandanus, screw-pine, the leaves of which are used to make mats throughout the Provinces. Nor is the place destitute of large timber trees, apparently indigenous. There are one or two species of acacia, Boodh's cocoanut, and two species of Wood-oil trees, one of which produces the oil from which torches are manufactured. $R$ atans are indigenous and abundant, and there are lumerous little forests of the gigantic bamboo, the largest species known, and peculiar to this country. Here too is game for the sportsman, and meat for the hunter. In short, Dōngyang is the most delightful place for an anchorite that ever was formed, and one can scarcely visit it without wishing himself a dervise or a monk.

During the rains the whole plain is under water, excepting a small sprinkling of islands on which the villages are located; and boats can sail from Maulmain to the very foot of the precipice ; and as if formed by some genii-architect for the purpose of seclusion and defence, this castellated pile, though forming to the eye in the distance a part of a continuous range, is really for all purposes of access quite isolated. On the north, as adverted to above, it is connected by a low ledge to the north-west portion of the range, and on the south and east a long narrow ravine is interposed between it and the southern section, through which a path is trodden by the Karens to the villages beyond the mountains.

Its form appears to the eye nearly like that of an equilateral triangle, with its sides about two miles long; and on a chart that was made by Lieut. Nalloth, of the Childers, that surveyed this part of the country seven or eight years ago, the base of this site is represented as of a triangular shape, with sides of from two to three miles long, but the whole space inclosed, is there depicted as a vast succession of limestone peaks. 
SIAM HILL.

There is some magnificent scenery in the Southern Provinces.

Taroy stands in an alluvial bottom, and is hidden in the distance by the tall palms, and glossy-green jacks, and yellowflowered cassias, and twenty other flowering trees unknown to song, which overshadow its humble dwellings; but Siam Hill is a conspicuous knoll, a hundred feet high, six miles long by half a mile wide, in the paddy fields half a mile east of 'Taroy.

Here, after emerging from the shrubbery that obstructs the view, there suddenly opens out before the spectator a prospect of indescribable beauty, "like a sleeping child too blessed to wake." At his feet lie spread out the level paddy fields, divided into numerous one-acre lots by little mounds raised around them to retain tlie water, so as to suggest a gigantic chess board. On the south a silver stream, fringed with the dark foliage of wild fig trees, and the thick straggling bushes of a species of Hibiscus, covered with large yellow: and red flowers, is seen pursuing its tortuous course beneath the shadows of Mount Burney, which rises twelve hundred feet above its southern bank. On the east, "hills peep o'er hills," like the seats of a vast amphitheatre, bounded by Ox's Hump, rising in a most picturesque outline four thousand feet above the plains. Yonder, at the distunce of fourteen miles, is seen a foaming cascade making a fearful leap from a gorge half way up the highest mountains. Green forests are diversified with white lichen-covered precipices, while here and there a whitened pagoda lifts its conical head above the summit of an isolated hill, or the smoke of a solitary hamlet is seen curling up in the midst of Wood-oil tree forests or Liquid meber groves.

"The Palm-tree waveth high,

And fair the Betel springs;

And, to the Indian maid:

The Bulbul sweetly sing

But I dinna see the broom

Wi' its tassels on the lea,

Nor hear the Lintie's sang,

$\mathrm{O}^{\prime} \mathrm{my}$ ain countrie !" 


\section{G TOIOG $\mathrm{Y}$.}

Crawford collected, and Buckland examined, a series of geological specimens of every rock seen from the delta of the Ir. rawaddy to the mountains north of Sagaing; from which it appears that the T'ertiary formation rests upon the transition, or mountain limestone, and the intervening conl measures of Europe are wanting. So far as the geology of these provinces is known, there is an exact correspondence on this point. We have Alluvium, Diluvium, T'ertiary, transition or mountain limestone, the Grauwacke formation, and Primitive, as in Burmah; and to complete the correspondence, we have a calcarious sandstone, which appears to be of the same age with a sandstone, that Prof. Buckland referred with doubt to the New Red Sandstone formation.

\section{UNSTRATIFIED ROCKS.}

GRANITE.

We step on shore at Amherst on granite, we meet with it on Double Island, Callagouk, and the islands opposite Yay, and from the mouth of Yay river to Tavoy Point the coast is one unbroken chain of granite. Beyond the Point this rock again appears, but is lost on the main land below the mouth of Pai xiver. 'There is also granite on King's Island, and prebably on some of the islands north of it. This granite wherever I have observed it, is composed of quartz, mica, and felspar, the latter usually white ; and sumetimes in crystals an inch long, constituting porphyritic granite.

On traversing the provinces in the latitude of Tavoy, another granite range is se€n about fifteen miles east of Tavoy river, which rises in some places two or three thousand feet high, and which $\mathbf{I}$ have traced in a S. S. E. direction to the vicinity of Mergui, and to the $N . N, W$. beyond the Burman villages, where granite appears crossing the river. This, however, is rarely, if ever, porphyritic, but the crystals of mica are often of considerable size, and the felspar frequently soft, 
and decrying. It is in this range that the tin of 'Tavoy province is chief found.

The dangerous reef called the 'Cows,' near where Tavoy river disembogues itself, is formed of porphyritic granite, containing large crystals of flesh-colored felspar. This variety has acquired the local name of

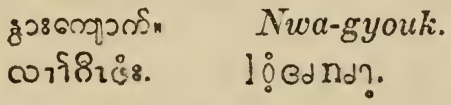

It is probably so called from its resemblance to the color of a red cow ; but tradition says that these rocks were originally a drove of cows which opposed Boodhism, and attempted to cross the river to beat down the pagoda opposite, on Tavoy Point, but the divinity looking out from the pagoda exclaimed, "Those are not cows, they are rocks ;" when they were all inmediately changed to stone.

It is a curious fact that while these ledges, which are constantly exposed to the water and the weather, are remarkable for their hardness, rocks of the same composition, at a locality not a mile distant on the shore, are in a complete state of disintegration, so that the crystals composing them may be picked out by the fingers. 'This fact tends to show that the disintegration of granite, is attributable to other causes than exposure to the weather.

Passing still farther east and down the Tenasserim, in about lattitude $13^{\circ} 40^{\prime}$, the river runs over a broad belt of granite, which has the same general features as the preceding. This is the most eastern granite that $I$ have met with in the province.

On proceeding up the river from Amherst to the headwaters of the Dahgyaing, no indication of granite occurs from Amherst Point to the base of the eastern mountains, where granite boulders appear in the brooks. This granite contains numerous crystals, of schorl but is apparently destitute of tin ; for it is not known that tin has ever been worked in Amherst province.

Mr. Lonsdale, the editor of the Maulmain Chronicle, says, " Granite is to be seen in abundance on the crest of that high range of mountains which runs nearly parallel with the Thoung-yin river, on the Shan or right bank. In the creeks, 
which take their rise in those mountains, and feed the 'Thoung• yinn, it is to be found in a highly decomposed state."

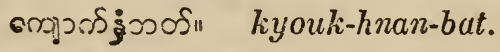

\section{GRANITE VEINS.}

In a sandstone hill near Mergui is a vein of granite, three feet thick, as described by Captain 'Tremenheere, which is a great repository of tin. Granite veins are seen in granite near Tavoy point; and there is a narrow vein of granite on the summit of the mountain range, that bounds the valley of $\mathrm{Ta}$ voy river on its east side. At Amherst, granite veins are numerous, mixed with greenstone dykes.

\section{SYENTTE.}

Referring to the mountainous range in the north-east part of Amherst Province, Dr. Helfer says, "In some parts occurs syenite, and only in one place granite." I have seen no syenite in the provinces, yet it may possibly exist in those mountains, though not probable. Granite boulders with schorl, that 1 collected at the base of those mountains, have been sometimes erroneously termed syenite.

\section{GREENTONE.}

At Amherst point the rocks are principally greenstone, with veins of granite and quartz. It has never been analyzed, but its nineral contents are manifestly different from the common greenstone of Europe and America. It has no indications of felspar, but contains considerable silex. It probably consists of hornblende, and quartz. Mr. Crawford enumerates all the other rocks at Amherst correctly, but does not mention greenstone. He has quartz rock in his list, in which he may have included the greenstone.

\section{GREENSTONE SLATE.}

Greenstone slate, or diorite slate, forms large dykes in all the three belts of granite in the southern Provinces. Baron des Granges, to whom I submitted specimens, said that the greenstone slate in the granite range nearest the sea was composed of "flint (silicum) and hornblende." The quantity of horublende must however be small, for it has the appear. ance of a silicious rock. It is rery hard, but has often a trap. 
pous structure, falling into angular pieces. 'To this rock we are indebted for nearly all our cascades. It often forms precipices, over which the mountain streams leap, and foam with great beauty. Katay river descends several hundred feet over a succession of these p:ecipices; and on the east side of the mountains, nearly in the latitude of 'Tavoy, is the finest fall I have seen in the provinces. At this place Hidu river falls into a cliasm some seventy feet deep, with banks for several hundred yards, as high and precipitous as the wall over which the stream plunges.

\section{IGNEOUS DYIKES.}

Igneous dykes are not uncommon, but they bear very litthe reseinblance in their mineral contents to the ordinary trap rocks of Europe and America. Some resemble quartz rock, others appear like altererl rocks, and many look like sandstone, which has been subjected to the action of fire. T'hat they have been ejected in a soft state is clear from their sides, which in some places abound with hemispherical cavities, into which the soft shales have been pressed, and their pressure probably produced the cavities. 'The shales are sometimes seen pressed upwards many degrees on the upper side of the dyke.

A remarkable dyke is seen in the upper part of the Tenasserim river. It runs like a wall nearly half way across the stream, and is called by the natives the "Giant's dam." It is about twenty feet high above the water, five or six feet thick, with perfect parallel sides, and is inclined some ten or fifteen degrees from a perpendicular. It is a silicious rock, with no traces of hornblende in its composition.

Some of these igneous rocks appear in hand-specimens to resemble grauwacke; and they have been confidently pro nounced to be grawacke, but when viewed in connection with other rocks in situ, their igneous origin is quite apparent.

\section{CLAYSTONE PORPHYRY.}

Among the sla'es and sandstones of 'Tavoy, claystone porphyry is nften seen, but I have never met with it at Maulmain, nor any where in Province Amherst. Excepting the mural masses of limestone, that province is an immense flat east- 
ward from Maulmain up to the base of the granite monntains, from which the Gyaing descends, except a low range or two of sandstone and clay slate ridges.

Tavoy, on the contrary, from Siam hil! on its eastern subburb, has precisely the opposite feature of being a continuous succession of hills and valleys up to the granite mountains. It is an interesting fact that this great difference in the natural scenery of the two provinces is almost wholly owing to the presence or absence of claystone porphyry. At Tavny, most of the picturesque little hills are formed of claystone porphyry, and were those hills melted down again into the bowels of the earth, whence they probably came in a melted stare, Tavoy would offer nearly the same natural features to the eye that Maulnain now does, excepting that one of the clay slate ridges is a little higher than those at Maulmain.

'There is a conglonerate on the islands opposite to Palaw, and in several places on the banks of the Tenasserim, which seems like slaystone porphyry studder! with fiagments of other rocks. It is sometimes a breccia, the fragments being angular bits of slate apparently of the beds below. This is most usually the character of the rock on the Tenasserim; but on the islands opposite Palaw, rounded pebbles are most numerous. In both localities the paste in which the fraginents are imbedded, forms the largest proportion of the rocks.

\section{STRATIFIED ROCKS.}

It is worthy of remark that, beginning at Mergui, the line of stratification gradually turns to the west on proceeding north, like the line of the coast. At Mergui the strike of the strata is about two points east of north and west of south; at Tavoy it is two or three points west of north and east of south ; at Maulmain three or four, and up the Dahgyaing five or six.

GNEISS.

I have seen no well marked gneiss in the provinces, but the granite is in some places gneissoid.

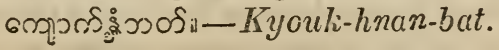

QUARTZ ROCK.

Specimens of what most geologists have characterized as greenstone, or greenstone slate, Dr. McClelland called "grey 
quartz rock ;" and where it appears in strata passing into ino durated clayslate, it is nearly all silex.

\section{Clay slate.}

Clay slate is usually the first stratified rock that rests on the granite. In the province of 'Tavoy it is indurated in some places so as to loose its slaty structure, and is a fine compact rock, resembling blue limestone.

MICA SLATE.

Mica slate is seen at $A$ mherst resting on the clay slate; and at Palaw, where the beds are much contorted, characteristic of this rock, no clay slate was observed between it and the granite; but the point of contact was not seell. East of 'Tavoy, thin beds of clay slate and mica slate alternate near the granite.

\section{PUDDINGSTONE.}

On the banks of the Tenasserim, near the eastern base of the mountains, in about latitude $13^{\circ} 50^{\prime}$ are inmense masses of puddingstone, consisting of water-worn boulders from a few inches to a foot in diameter, firmly united together ; and form. ing what is often called transition puddingstone.

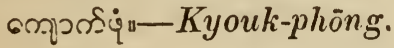

SANDSTONE.

Sandstone most frequently appears next above the primitive slates, and then alternates with clayslate several times before the limestone appears. In one place, however, a few miles south of Toung-byouk river, red sandstone is seen resting on the granite, no slate being present.

When the stone contains red ochre, as on Siam hill near T'aroy, the Burmese call it

เฉฐ"Kue-nee.

\section{LATERITE,}

Laterite is seen lying above the slate at Amherst, and is spread over the sea-coast nearly down to $\mathrm{Y}$ ay, when the granite appears again, and so far as my observation extends, it is seen no more on the sea-board. In the interior of the southern provinces some portion of the sandstone beds partake of the laterite character; but it is not developed there as in Ar. 
herst province. After leaving Amherst point, laterite appears at Maulmain alternating with sandstone, and it is seen distinctly stratified at the base of the eastern mountains, at the head of the Dahgyaing.

This rock seems to be peculiarly Indian. Its name even is not found in European and American works on geology. When not exposed to the weather it has the appearance of a porous iron clay, somtimes including fragments of other rocks; and from its quality of hardening when exposed to the atmosphere, it has been used extensively for bricks for pagodas and other purposes, and has hence been named Laterite, from Later-a brick.

Geologists are much divided in opinion whether to regard it as a trap rock, or as a stratified one. In these provinces, it appears to be more of a conglomerate than any thing else. In some localities, as at Maulmain, it includes large fragments of sandstone, several inches in diameter. The geological position of the laterite at Amherst and Maulmain, is precisely that of decided beds of conglomerate near T'avoy, which lies immediately above the slate strata that rests on the granite.

The Tavoy conglomerate consists mainly of quartz pebbles, or angular fragments of quartz united by oxide of iron, which soils the fingers. Some parts of the strata are so fine that Dr. $M^{c}$ Clelland pronounced specimens that were sent him to be "sandstone, old." Other parts are coarse, with pebbles half an inch in diameter, and in some parts the rock is slightly amygdaloidal, approaching laterite; while on the other hand, there are portions of the laterite at Amherst and Maulmain which are considerably compact, with quartz fragments; and specimens might be selected with ease which could not be distinguished from the Tavoy conglomerate.

I never met with any rock even resembling laterite in the valley of the Tenasserim; and prof. Buckland does not appear to have had any in Mr. Crawsord's specimens from the valley of the Irrawaddy. .

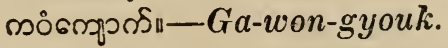

LIMESTONE.

The limestone of the provinces wherever it has been traced, is found resting on a thick succession of slate and sandstone 
strata, between it and the granite. On the Salwen it contains Jead ore, like the metalliferous limestone of England and America, and it is not wholly destitute of fossils, although they are very rare. Captain Tremenheere found a species of Terebratula in the Tavoy limestone, which is characteristic of the English mountain limestone; and it may therefore be regarded as identical with the carbonife:ous limestone of the coal formiation.

\section{MILLSTONE GRIT.}

Beds of conglomerate or breccia appear above the limestone in 'Tavoy province, where they occupy the place of the millstone grit in Eugland. 'They appear, lowever, to belong to a more recent formation abore the coal measures.

T ERTIARY.

'Tle Tertiary formation is fully developerl in the valley of the Tenasserint. There are found beds of pebbles and sand partialy consolidated; plastic clay containing lignite; soft shales with impressions of recent plants; and in some places, calcareous grit and gypsum, with congtomerates composed of enormous masses from the adjoining rocks.

Whether some of these belong to the tertiary or the new red sandstone formation may admit of doubt. Such products are found in both, and until they are ascertained to contain organic remains decisive of the latter, to separate them from the former is to make an arbitrary and unnecessary division.

- A red sandstone from the neighbourhood of Pagan is imported into the provinces, for the use of Burmese women, to grind up their odoriferous woods upon, of which Dr. Buckland says: "It may with more probability be referred to the new red sandstone than to any other formation." The stone umbrella of the image at Amberst point affords a specimen of this rock.

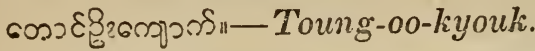

\section{DILUVIUM.}

The richest tin locality in the province of Taroy is at the base of the eastern mountains, where the vallies are covered with a thick bed of diluvial pebbles and boulders, eight or ten feet thick, below which no tin is found. 


\section{CROSS SECTIONG.}

FROM MONMAGON TO THE TEAASGERII.

Were a person to land at Monmagon, opposite the middle Moscos, and proceed across the province of 'Tavoy to the Tenasserim, and down that river to the highest point where Dr. Helfer found coal, he would see on the way nearly every rock that has been discovered in the Provinces. At Monmagon granite rocks appear below high water mark, and thence to the base of the range of hills tliat separates the valley of Tavoy river from the sea, is a sandy plain a mile across, which seems to have been originally covered by the ocean. The hills from the base to the summit are granite, rising at thes right of the road to fourteen hundred feet ligh, as measured by Capt. Glover.

On the eastern declivity greenstone slate shows itself, and thirty miles further south, there are granite and greenstone down to the bank of the river. On descending the hill however from Monmagon, a well has been dug at its base, and from the bottom of the well a soft friable white stone brought up, which Baron des Granges said was "green sandstone, much decomposed-cretaceous group." The accuracy of this statement may be well doubted from the Geological position of the rock, but it is quite a peculiar sandstone, and I have not seen any thing exactly like it in any other place in the provinces. It bears some resemblance to very fine granular quartz.

Clayslate next appears, and continues to the banks of Tavoy river. In some places a kind of iron stone is seen, and a short distance nol th of the road there is a hill composed almost entirely of magnetic iron ore, while the bottom of a well in the vicinity, is floored with 'I'remenheerite.

After crossing Tavoy river there is an. alluvial plain, one or two miles broad to Siam Hill, where a red conglomerate appears, bearing a strong resemblance to the laterite of $\Lambda$ mberst. province, and on its eastern margin is an igneous or altered rock, abounding in amygdaloidal cavities and pyrites $\Lambda$ precisely similar rock, but with less iron prites, is seen in the laterite at Monpoon This is succecded by an alluyial plain, but 
the banks of Pagaya river which crosses it, show clayslate cropping out below the alluvium which is remarkable for containing a large quantity of small iron pyrites. Specimens of this slate after being in the cabinet one rains, were covered with a thick efflerescense of sulphate of iron, or copperas, from the decomposition of the pyrites. 'The hill at the village of Salung* which bounds this plain, is formed of claystone porphyry, soft, and of a bluish color, where not exposed to the weather. The little knoll a mile further east, on which the village of Ta-laing-doungt stands, appears to be formed of claystone. Soon after this white sandstone appears, and half a mile beyond, Nga-than-kyoung $\ddagger$ is seen running over a ledge of white sandstone rocks. The same rock appears at intervals for two miles farther to a little distance east of the village of Pyee-doung,, where an igneous dyke crops out of the bank of the river that has been called, but it is believed erroneously, grauwacke.

The hill east of Pyee-doung is formed of claystone porphyry of a reddish color, and more indurated than that at Salung. A small hill beyond has slate clay, and furnishes all that is seen in Tavoy bazar; and a hill east of this, shows claystone porphyry again near the mouth of Bya-hung-khyoung.|l Beyond this, a micaceous-slaty sandstone is seen cropping up across the road, and a few hundred yards farther east, common white sandstone is seen in the banks of Pagaya river. These sandstones appear near the base of a range of hills from five to eight hundred feet high, that reach Pagaya river at its forks §bout nine miles from Tavoy. 'This range seems to be wholly composed of thin lamina of slate, principally clayslate, in some places much contorted. Dr. M'Clelland designated one specimen that was sent him as "chlorite slate." The strata make an angle with the horizon of about $30^{\circ}$. East of this range, claystone porphyry appears again, and beyond this in the bed of a little stream, limestone apparently stratified shows itself, the beds making an angle of from $20^{\circ}$ to $30^{\circ}$ with the horizon.

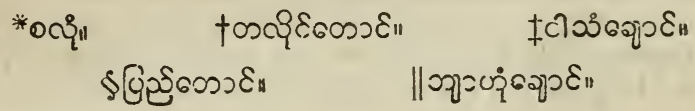


This is the locality from which Captain T'remenheere obtained specimens containing casts of a species of terebratula, which identifies it with the English mountain limestone.

In a small brook descending from a hill east of the limestone, are seen numerous beds of breccia, containing angular pieces of sandstone and quartz pebbles. They make an angle of $30^{\circ}$ or $40^{\circ}$ with the horizon dipping to the east, and leaning towards the granite west of Tavoy river as an anticlinal axis; as do all the other stratified rock that have been passed over, but this is the uppermost in the series; for the next that are reached a mile farther east are found dipping to the west, and leaning to the eastern belt of granite. The strike of the strata in all these rocks where observed, was from two to three points west of north and east of south.

The highest beds in the next series of rocks, appear in a range of hills back of the Karen village of Thalu or Lung-lung." They consist of clay slate with sandstone alternating, some of them might be denominated colored shales. The strata are much contorted, and though in some places they make a small angle with the horizon, in others they appear to be nearly standing on their edges. Old red sandstone much indurated next appears, and beyond this in Khat brookt what Dr. M'Clelland called, " a finely laminated mica slate" coarsely!laminated with layers of clayslate." The strata are nearly perpendicular.

'T'his is succeeded by $M$ 'Clelland's grey quartz rock, the greenstone slate of others; and hard clayslate with imperfect crystals of andalusite macle or chiastolite follows. Where the clayslate shows itself five miles north of this locality, it is filled with crystals of macle that are perfect. The next beds appear like graphic slate.- "Dark blue, uniformly mottled on the cleavage with dull specks of mica-soil and write ;" says a correspondent. The "dull specks of mica," it is believed, are disintegrated, or imperfectly formed crystals of mackle. It is certain that perfect crystals of this mineral are found among them. Clay slate with layers of mica slate follow, and in learing this rock near the mouth of Nyoungf breck; and ascending

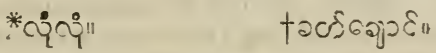

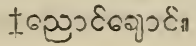


the mountairs, claystone porphyry in a very indurated state, is found more than a thousand feet above the valley below. This is succeeded by clay state, and grey quartz rock, or greenstone slate, and thien granite is again seen at perhaps two thousand feet above the sea.

After leaving the granite on the northern route by Lokekhyen, the first rocks that appear are different varieties of indurated or silicious slate. On the summit of the ridge which divides the waters that fall into the sea from those that pour into the Tenasserim, greenstone slate appears again, weathered on the outside for nearly an inch deep into a rock resembling red sandstone, or some varieties of lateritc. On the summit of this ridge, which has a little table land, a narrow vein of granite obtrudes in a fine grained porphyritic rock. The vein is not more than half an inch wide and consists principally, if not altogether of mica and quartz, the former in the greatest abundance; and the rock which the rein pierces, seems to consist of the same minerals but contains numerous crystals of mica diffused throughout, that appear to have been formed there when the rein was ejected, for they are most numerous nearest the rein.

On descending the mountains into the valley of the 'Tenasscrim, indurated clay slate, and quartz rock are repeatelly seen, and on these rests a white sandstone. At the foot of the mountains for a space of about six or eight miles long by three or four miles wide, is a diluvial deposit six or eight feet deep, rich in tin, and containing a little gold.

When the banks of the Tenasserim are reached a few miles enst of the diluvium, a succession of beds of conglomerate or pudding stone are seen, consisting principally of rounded pebbles cemented by the hydrate of irons. They are inclined at a small angle with the horizon, and dipping towards the west and north, lean towards an anticlinal axis east and south. $\mathrm{A}$ few miles north of this locality, and lying above the conglomerate are beds of clay containing lignite.

Descending the river to the high bauks at the forks of the 'T'enasserim, beds of indurated sand are seen cropping ont beneath the conglomerate, which abound in impressions of leaves of dicotyledonous plants resembling the leares of existing species, and below these, down to the water's edge are beds of sliale 
containing the carbonized stems of plants, and casts of small shells, some of which bear a strong resemblance to shells of the genus onchus. In the river and on the banks below, a breccia appears, which in some parts is a hard rock with numerous crystals of lime inclosing angular bits of shate; in others, it is a loose conglomerate with rounded pebbles of quartz, angular bits of white quartz, grains of mica, bits of decomposing felspar, large pieces of shale that seem to have been united with the mase in the form of clay, and numerous small rounded pebbles of chlorite, a rock which I have no where seen in situ in the Provinces. Below this conglomerate are the thick beds of shale, which have furnished the conglomerate with its fragments.

T'he river after leaving these shales, passes out of the open country, in which it has been rushing, into a hilly region, and the character of the rocks is immediately changed. Greenstone slate appears, and that is followed by a rock which some geologists have called an altered rock, but which corresponds almost precisely to a variety of claystone porphyry from Hungary, which I saw in the museum of the Asiatic Society. A few yards from the bank of the river, just below these rocks, are sulphureous hot springs.

For several miles further down, there is a succession of olay slate and sandstone strata, and they are followed by a conglomerate or breccia or grauwacke or claystone prophyry, for it admits of all these names. It is formed of a paste of claystone porphyry, imbedding more or less fragments of the clay slate on which it lies, and the fragments are usually angular. On the islands opposite Palau, a similar rock is found with rounded quartz pebbles. Resting on this rock in one place near the bank of the river, is a large mass of white limestone with veins of red oxide of iron running through it, that give it a fantastic appearance; and the Karens call it the "Giant's scull." It lies at the base of a high hill, from the summit c $f$ which it appears to have fallen, and where the limestone is doubtless in situ. 'This conglomerate continues for' several miles, farther down, when clay slate re-appears, and ifter in few miles, it is followed by a basin covered with tertiary beds similar to those seen above.

Just above the mouth of Moung khyoung, from one to (wn 
hundred feet of the beds are seen on the side of a precipice, the lowest of which is one of indurated slate clay, and above that, a very thick bed of conglomerate composed of angular fragments, as I judged, of the slate formation next below. Some of the fragments of slate are several feet, not to say yards, in cubic contents with their angles as sharp as if just broken from the rock to which they originally belonged. It should be observed however, that while some of the fragments appeared to be hard blue slate, many others were soft colored shales, apparently of the same age as the formation itself. It contains no boulders or fraginents, so far as I could discover, older than the slate.

At the mouth of Noung khyoung there appears to be a fault. A few hundred yards above the mouth of the stream, a hill some two hundred feet high suddenly appears on the alluvial bank of the river, with precipitous sides to the north and west, in which the strata are seen dipping down to the south. On reaching the mouth of the stream the river is very deep, broad, and still, and forms a small lake, and the strata again appear in the side of a precipitions hill below the mouth of the stream, dipping in precisely the opposite direction from that above, and at a considerably higher angle, while a short distance below, the hill disappears, and the strata are seen in the deep bank dipping in the same direction, but in a much smaller angle, and in the same direction, that all the strata below dip until reaching the granite. A fault at the mouth of the stream might produce these irregularities, by throwirg down the ends of the strata on both sides of it, but most on the northern side. Slate clay coktaining alum, and granular gypsum are both found in this neighborhood.

On passing out of this basin, the claystone porphyry conglomerate is again observable for several miles; then clay slate, and that is succeeded for several miles by tertiary conglomerate, like indurated gravel, until granite is reached again in about latitude $13^{\circ} 40^{\prime}$. Clay slate is seen resting on the granite on the south side, and that is followed by a succession of precisely similar rocks to those, that have been passed between the forks at Mata and the granite.

In about Latitude $13^{\circ} 20^{\circ}$, are some curious piles of limestoné resting on the claystone pirphyry conglomerate, beneath which 
clayslate crops out several hundred yards in thickness, and dipping at an angle of about $45^{\circ}$. 'T'he limestone appears in two or three isolated masses more than it thousand feet high with perpendicular sides, and apparently quite inaccessible. They resemble the limestone cliffs of Maulmain, but differ from them in being distinctly stratified in beds of a few feet in thickness. Though in sight of the river they are several miles from its banks, and only a very short distance above the highest point where Dr Helfer found coal. The coal lies above the limestone, and that is the place to look for true bituminous coal, but this is unquestionably wood coal or lignite, which shows that the coal measures are wanting in this place.

'The geology of the valley of the Tenasserim below this point to Mergui, is only a repetition of what has been seen above.

FROM AMHERST TO THE TIOUNGYEEN.

A trip across the Province of Amherst is of far less interest to the geologist, the rocks being seen in much less variety. At Amherst, granite and greenstone are succeeded by clay slate, mica slate, and laterite. At Moopoon, the laterite is seen again, and at Maulmain, sandstone, laterite, shales, and slate clay constitute the rocks, so far as they appear. At the mouth of the river Gyaing, where the white Pagoda stands, is sandstone; and from that point to the old city of Gyaing, the only rock seen is limestone.

The hills back of Gyaing are composed of sandstone and shale; the strike of the strata being north north-west and south south-east, with a dip of about $45^{\circ}$ to the east, leaning like the strata at Maulmain towards the granite at Amherst as an anticlinal axis, which shows that the limestone on the plain lies above the strata at Maulmain, and below that at Gyaing. On proceeding up the Dahgyaing, tertiary beds of a soft conglomerate resembling indurated gravel, are seen; and the lignite, which Mr. O'Riley says has been found on this river, probably exists in this formation.

In one or two places the river runs over banks of shale, dipping like the preceeding strata to the east ; the highest being within eight miles of the head of boat navigation, and this is the last rock seen dipping to the east.

When within eight miles of the eastern mountains, strata 
appear dipping to the west and leaning towards the granite in those mountains. Laterite, clayslate, mica slate, and granite are found on rising the mountain, and thence to the banks of the 'Thoungyeen, the boundary of the' Province, a gentleman, who collected specimens for me, found nothing but limestone. Capt. Latter mentions sandstone as being abundant in the valley of the Thoungyeen, and Mr. Lonsciale says that the valley is bounded on the eastern side by granite mountains.

\section{THE R M A S P R I N G.}

The Provinces are well supplied with hot springs; and some of them are probably not inferior in their medicinal qualities to the fashionable Spas of Europe and America. 'Though their waters have never been subjected to any minute analysis, yet we know there is a great variety in the properties of different springs. 'They may be arranged in three different classes,-carbonated, sulphureous, and saline.

\section{CARBONATED TIIERMAL SPRINGS.}

The hot springs on the Ataran, according to Dr. Ilelfer's description, belong to the carbonated class. 'They are situated within two miles of the old town of Ataran, and Dr. Helfer writes: "There are ten hot springs or rather hot water ponds, of which 1 could only examine the nearest, as the access to the others was through deep water at $130^{\circ} \mathrm{F}^{\prime}$ areuheit. 'This one was a semicircular pond about fifty feet in circumferance. In one place it was thirty five feet deep. 'T'he quantity of carbonic acid which the springs evolrc, seems to render the neighborhood peculiary adapted to support vegetable life.-'The ground around the spring is strongly impregnated with iron, and the water which runs over the ochre mud has a strong styptic taste. "The springs on the Ataran approach in their composition nearest to the celetrated waters of 'I'cplitz."

" 'Their medical properties would render them excellent remedies in a number of diseases, liver complaints would find a powerful remedy in them. If Amherst should be selected as a resort for invalids, the hot springs on the Ataran could easily be turned to advantage. In a direct line, they would be only four or five hours distant, and a road could be cut 
through the country without difficulty, so that patients could be removed there and bathe in loco."

Dr. Morton found on analysis, that the waters contain a considerable quantity of calcareous matter, and that the tufa which it deposits on the border of the springs, is a carbonate of lime. They appear to arise from the mountain linestone, and thus to hold a geological position similar to that of the hot springs of Great Britain, most of which rise fron strata below the coal, and hence from, $n{ }^{\circ}$ through the limestone.

\section{SULPIUREOUS THERMAL SPRINGS.}

A bout four miles below Matah at the forks of the Te. nasserim, and a few miles north of the latitude of Tavoy, there are hot springs highly charged with sulphuretted hydrogen gas, so readily recognized by its smell which is precisely that of the washings of a gun barrel; the odo: in both instances being produced by this same gas. All the stones in the springs are of a bright brass color, produced apparently by the deposition of the sulphur; and although the virtues of these waters are hidden from man, they appear to be well known to the beasts of the forest. To judge from the tracks around in the morning, the most incongruous parties are held here every night. The delicate little tread of the cherrotain and barking deer, are seen side by side with the massive steps of the elephant and rhinoceros; and the tiger, and the leopard seem to lay as!de their fiereness, and peaceably walk away satis. fied with a draught of the much coveted beverage.

Dr. Ife!fer said these springs belonged to "the class of su!phureous mineral waters, tinged slightly with chalybeate, like the water of Brighton." Their heat above the a: nosphere is not great. Mr. Benneft at a recent visit, found the thermometer to rise in the hottest spring to only 119 . They rise from the slate rocks, like the warm aprings of a considerable part of Germany.

\section{SALINE THERMAL SPRINGS.}

On the margin of the granite range east of Tavoy, either ncat the junction of the slate and granite, or in the 
granite itself, is a series of the hottest springs in the Prov. inces. I have visited four or five in a line of fifty or sixty miles, and found them uniformly of a saline character. Around one nearly east of Tavoy, the stones are covered with an efflorescence resembling epsom or glauber salt. Mr. Bennett found the Thermometer in this spring, to rise to $144^{\circ}$. Major McLeod visited one of the series at Palouk, and writes: "There are two spots where the springs show themselves. One immediately in the right bank of the river, and another two or three minutes walk to the northeast inland. - There must be 30 or 40 bubbling up along a line of about 50 feet by 20 . - The hottest was $196^{\circ}$ another $194^{\circ}$. No disagreeable smell or taste."

The hottest springs are at Pai, ten or fifteen miles north of those visited by Najor McLeod, and according to Phillips they are hotter than any on record out of volcanic regions, with the questionable exception of three springs in China, which, "probably exceeded the temperature of the air from 70 to 120 degrees." The principal spring at Pai,-for there are several, is in a little sandy basin in the midst of granite rocks on the margin of a cold-water stream, where it bubbles up from three or four vents, and on immersing the thermometer into one, the mercury rises to $198^{\circ}$, within fourteen degrees of boiling water. Its location is rather peculiar, not being in a valley like the others $I$ have seen, bat on the side of a hill more than a thousand feet above the level of the sea, and surrounded by large masses of coarse grained granite rocks, which seem to have been detached from the summit above. 


\section{IVIMERALOGY.}

Our knowledge of the mineralogy of the Provinces has been increasing with each successive year, and will probably contiue to do so for many years to come. Lead rich in silver, copper, manganese, Tremenheerite a new mineral, chiastolite, chalcedony, carnelian, and agate have all been discovered within the last ten years; and we have every reason to beliere, that the next $t \in n$ will not be less fruitful in discovery.

\section{EARTHY MINERALS.}

COMMON QUARTZ.

Common quartz is one of the most abundant minerals in the Proxinces.

$$
\text { ธก์วิ: }
$$

\section{CRYSTALLIZED QUARTZ.}

Small crystals of quartz are common in the Provinces, and large specimens of rock crystal are sometimes brought from the Siamese frontier. Some of the "Ceylon diamonds" which the Ceylonese offer for sale, are made of rock crystal; and many of the "rubies," and other precious stones, that the Shans bring with them in their annual caravan from the north of Burmah, are made of rock crystal colored artificially. They are heated and plunged into colored solutions. A gentleman of my acquaintance being about to wisit Calcutta a few years ago, purchased a few of these " jewels," a great bargain, of a Shan who was anxious to return home, and therefore sold for fifteen rupees what, he said, was worth a hundred. On being subjected to the examination of a jeweler in Calcutta, they were found to be all either colored quartz, or paste, and not worth fifteen pice!

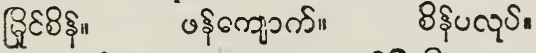

$$
\begin{aligned}
& \text { 100日!จ? }
\end{aligned}
$$


GREF QUARTZ.

Green quartz, or prase, is sometimes found in the form? of pebbles in our mountain streams, but it is not fery abundant.

MILKY QUARTZ.

Milky quartz is occasionally found in the Mergui alsd Taroy provinces.

AHETHYST.

Pebbles of amethyst, or violet quartz, are brought from the rivers in Burmah, where they are regarded as a variety of the sapphire; the Burmese name signifying "Eggplant sapphire," or, as they are sometimes called, "Eggplant flower stone," from the blue flower of the egrg-plant.

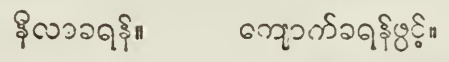

TELLOW QUARTZ.

I have met with dull specimens of yellow quartz, or citrine, on the Tenasserim; but it is not common.

GRANULAR QEARTZ.

The laterite often incloses fragments of a granular quartz rock, which crumbles to pieces in the fingers into a fine quartz sand.

\section{CAT'S EYE.}

'The cat's eye, a gem, which gives out a pearly reflection resembling the eye of a cat, is often seen set in rings, and is brought from Burmah. Comstock says: "It is in great request as a gern, and bears a high price;" but those seen in Maulmain market are not much valued. A small one may be purchased for two rupees, and one of ordinary size for five; while ten rupees is the highest price given for the best.

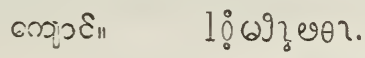

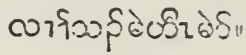

FLINT.

Flint does not appear to be found either in the Prorin. 
ces, or Burmah; all the flints that are used being imported from Bengal.

$$
\text { Bsจ }
$$

\section{COMHON CHALCEDONY.}

Chalcedony, both white and yellow, has been discovered at Moopoon near Maulmain, and is very abundant in Burmah. "Chalcedony passes insensibly into agate, and carnelian, and perhaps into hornstone."

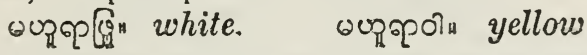

CACHOLONG.

Streaks of cacholong, or milk white chalcedony, are seen on some of the agates.

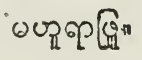

SARD.

"This is of a deep rich, reddish brown color, probably a variety of caruelian," but by some regarded as a variety of chalcedony, and is seen oceasionally as constituting a part of some of the agates offered for sale.

$$
\text { Quฺฺ? }
$$

ONYX.

Mineralogists are not agreed in the definition of onyx. According to Comstock, it is a variety of chalcedony, " consisting of alternate layers of opake milk-white chalcedony, or cacholong, and of the bluish translucent chalcedony," - the chalcedonyx of Jameson. Such are found at Moopoon.

$$
\text { טup }
$$

Aiken says: "Two or more plates of any of the varieties of the chalcedony form the onyx." "Such are found in Burmah, if not in the Provinces.

$$
\text { Qunต }
$$

\section{SARDONYX.}

According to Cornstock, sardonyx consists of stripes of 
"onyx and sard," or sard and chalcedony; and such stones are occasionally seen in the hands of the natives

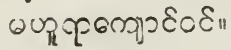

\section{CIRNELIAN.}

Carnelian is rery cominon in Burmah, and has ween found at Moopoon and Mlergui. "Its principal color. says Jameson, "is blood red, of all degrees of intensity. One of its Burman names is, "Fowl's blocd."

$$
\text { लु. }
$$

"It also occurs sometimes milk-white, and "m som? specimens it is difficult to decide whether it belongs in chalcedony, agàte, jasper, or carnelian." Some parestic are yellow.

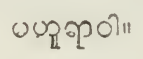

BLOODSTONE OY HELIOTROPE.

The green stone with red or yellowish dots caite. bloodstone, or heliotrope, is not rare; but whether found in Burmah or not, is uncertain. The natives call $2 \mathrm{t}$ by tic same name that they do grcen jusper.

$$
\begin{aligned}
& \text { รेกी:०ें } \\
& \text { AGATE. }
\end{aligned}
$$

Arrate is found at Hoopoon near Maumain, and the 1$]$ :Ti. is say at Mergui also.

$$
\begin{aligned}
& \text { wusต }
\end{aligned}
$$

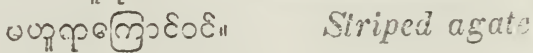

It the siripes are chalcedony and cacholong, then the stonc thus designated will be the onyx Chalectonit c...riclian, agate, and ony $x$, are all

$$
\begin{aligned}
& \text { wus?" } \\
& \text { YELLOT JASPER. }
\end{aligned}
$$

I hare met with yellow jasper on the T'enasserin, i? is not? common occurrence.

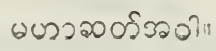




\section{GREEN SASPER.}

A soft green jasper of which $I$ have specimens, said to be found in the Provinces, the Burmese call,

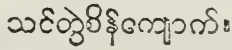

Precious green jasper, including strined jasper, is called by the Burmese,

$$
\text { के กी:श्ठे" }
$$

FRECIOÜS GARNET, OT ALHANDINE.

Precious garnets in the form of pebbles, are often seen for sale among the Burmese; but it is not certain that any are found in the Provinces. Mineralogists say, the inost beautiful come from Sirian the capital of Pegu. It is the carbuncle of the ancients.

"In a creek on the Siamese side" of the Tenasserim valley, Dr. Ilelfer says "rubies are found. They are however of a very inferior description"--probably garnets. crgyว

uई口] a variety with a violet tinge.

\&仑ำin inferior varietics.

COMMON GARNET,

The common garnet is occasionally seen in the sands of our rivers, but it is not abundant.

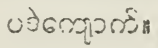

\section{PIROPE.}

A rarieiy of the garnet, either ideritical of nearly resem. bling the pyrope garnet, is brought from Burnah. It is characterized by giving to transmitted light a jellow tinge, or as the natiress sav, the the color of the ox's gall; and hence the Burmese name, which in Pali signifes ox-gall.

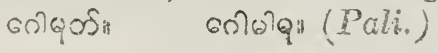

\section{CLAYSLATE}

Chayslate is a very abundant mineral throughout the provinces, and is found in numerous varietics, soft shales, 
and hard indurated slate abounding in silex; roof-slate, and a variety that soils and writes like graphic slate.

RDOF SLATE.

In some localities, especially in one near the head waters of a branch of Toung-byouk river, the clayslate cleaves into large thin plates that would serve fir rouf zlates, or for slates to write upon.

\section{SHALE.}

Shale characterized as in "layers often uneven, protuberant, or knobby-often disintegrates and falls to pieces," is abundant in the neigliborhood of Maulmain, and near the forks of the 'Tenasserim.

\section{BITUMNOUS SHALE.}

Shale containing regetable impressions, and carbonized stems of plants, is found at the forks of the T'enasserim, and perhaps belongs to the class of bituminnus shales, though it does not appear to contain much bitumen.

\section{GRAPHIG SLATE.}

A slate that "soils and writes," as Dr. M'Clelland described it, is found east of Tavoy, and another and softer variety is found in Maulmain near Tremenherite. They may be justly regarded as varieties of graphic slate.

\section{SILICIOUS SLATE.}

Silicious slate is found near the granite mountains esst of Taroy. By some it is denominated indurated slate.

\section{CLAYSTONE.}

There is a thick bed of reddish claystone, a few miles east of Taroy, that cannot be distinguished in hand specimens from Scotch claystone.

$$
\text { IRON CLAY. }
$$

Iron clay is very abundant in the laterite, which is often wholly compesed of iron clay. 


\section{PORCELAIN CLAY.}

The clays have not been analyzed, but there are clays at the bases of some of the granite mountains, where the felspar has decomposed so much, that the paths are thick with a conrse quartzose sand, and a few grains of mica that remain. As porcelain clay is produced by the decomposition of felspar, such is probably the clay in the localities to which reference has been made.

\section{POTTEIR'S CLAY.}

The clay in which the petified trees are found has the appearance of fine potter's clay; and clays from the banks of the Ataran and Gyaing rivers were found, Mr. O'Riley says, "after several trials at the Calcutta mint, to possess every good property of the best English fire clays."

\section{LOAM, Or BRICK EARTH.}

The alluvial beds within the reach of tide waters, contain numerous strata from which bricks are made.

\section{REDDLE.}

Reddle, or red chalk is seen in the bazar, but it is imported, though it probably exists in the provinces.

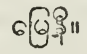

\section{AUGITE.}

On the banks of the rivers near Maulmain and Tavoy, masses of dolerite are found which contain augite. They are not however found in situ in the Provinces, and have probably been brought from the Isle of France.

\section{HORNULENDE.}

I have met with hornblende as a constituent of greenstone; but never in the Provinces in any other connection,

\section{LABRADOR HORNBLENDE, OF HYPERSTHENE.}

Baron des Granges, to whom was sent specimens of the greenstone east of 'Tavoy, said that the hornblende it contained was Labrador hornblende. 


\section{BLUE SAPPHIRE.}

Blue sapphires are brought from Burmah, and Dr. Helfer writing from Mergui says: "A Karen informed me, there are precious blue stones to be had, which the Shans collect and carry to Bangkok. He described the place as eight days distant, and did not know whether it was British or Siamese."

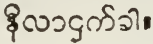

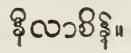

RED SAPPHIRE, OT ORIENTAL RUBY.

The red sapphire, or ruby, is brought from Burmah, where it is found with the common blue sapphire, probably in the valley of the Salwen. The Burmese call it by the same name that they do the precious garnet, and do not appear to be always able to distinguish them.

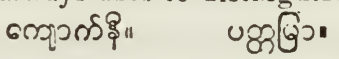

VIOLET SAPPIIRE.

The violet sapphire, or Oriental amethyst ; is found in the same localities as the common sapphire.

$$
\text { ริงาวด์ }
$$

YELLOT SAPPHIRE.

The most valuable topaz in Burmah, is the yellow sapphire, or Oriental topaz.

$$
\text { ElW0งฺ̨" }
$$

GREEN SAPPHIRE, Or ORIENTAL EMERALD.

A green gem is often seen for sale among the Burmese, brought from Burmah, which Europeans usually call emerald; but it is probably a blue sapphire. 'The true emerald may however be among them.

Q3n

\section{CORLNDUM.}

Corundum pebbles are found in " the gem-sand of Ava river;" and they probably exist in the sands of some of 
the rivers in these provinces. The common emery is a variety of this species.

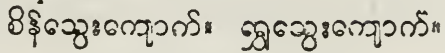

\section{SPINELLE RUBY.}

By far the larger proportion of the rubies offered for sale, are, it is believed, spinelle rubies. I have a small specimen which every native, who has seen it, regards as one of the best kind of rubies, or red sapphire, but its natural crystalline form is easily recognised, as a regular octahedron; while that of the oriental ruby is a six sided figure, or some of its modifications. 'They are seen of all shades. Blood red, the proper spinelle ruby; rose red, the balas ruby, orange red, or rubicelle; and violet colored or almandine ruby. It is no easy task to distinguish, accurately, the true character of the different stones offered for sale as rubies. Both Europeans and natives often make great mistakes. An English officer bought a "ruby" in Mlaulmain a few years ago for fifteen rupees, his friend bought one for five rupees; and the rubies were thought to be of nearly equal value; but on walking into a jeweler's shop in Calcutta, a year or two afterwards, the jeweler offered four hundred and fifty rupees for the one, but refused to give two rupees for the other, characterizing it as " a worthless garnet."

$$
\text { rrophis" u\& Go" }
$$

8 Eิ|n:" the inferior varieties.

CEYLANITE.

The dark blue, or blackish varieties of spinelle, called Ceylanite or pleonaste, are often offered for sale by the Shang under the same name as the sapphire.

$$
\text { \$coso }
$$

\section{$\Lambda V A$ GEM-SAND.}

Gem sand from the neighborhood of Ava, is sometimes one of the Shan articles of merchandize. It consists of small fragments of nearly all the precious stones found in the country, but garnet, beryl, and spinelle are its principal constituents, more especially the last, which seems to 
constitute more than three fourths of the whole mass. A single handful will contain specimens of every shade, black, blue, violet, scarlet, rose, orange, amber yellow, wine yellow, brown, and white. Many retain their original crystaline forms, some have the fundamental form of the species, a perfect octahedron ; but many others have some of the secondary forms, among which it is not uncommon to see twin crystals with three re-entering angles, formed by two segments of the tetrahedron truncated on the angles, and joined together by their bases.

\section{COMMON SERPENTINE.}

Dr. Helfer found serpentine on the islands of the Mergui Archipelago, and Dr. Morton picked up a boulder near Amherst, containing a small vein of common serpentine; which indicate its existence in the Provinces, although no defuite locality where it exists, is known.

\section{PRECIOUS SERPENTINE.}

Precious serpentine exists int he Ilookhoong ralley, north. west of $A$ ya, whence it is exported to China, and brought into the southern parts of the empire, but it has not yet been discorered in these provinces.

$$
\text { cipjo }
$$

ZIRCON.

Some of the best of the Ceylon jewels are probably zircon, the pale variety of which supplies the diamonds used in the jeweling of watches; and Jameson says, it is often sold as an inferior kind of diamond.

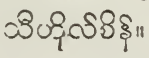

BERYL.

Beryls are found in the sands of the Irrawaddy; and may probably be found in some of the rivers, that descend from the granite mountains in these provinces.

$$
8 \oint_{1}
$$




\section{ACIDIFEROUS EARTHY MINERALS.}

CARBONATE OF LIME.

This is a very abundant mineral in the Provinces and embraces several varieties.

\section{STALACTICAL CARBONATE OF LIIIE.}

All the limestone caves have stalactites hanging from their roofs; and stalagmites raised on their floors. The Siamese Karens often bring over bits of limestone of the shape of a shell, and when broken, a shell usually of the genus melania appears, that has been encrusted with carbonate of lime. Nuch of the alabaster of which ornaments are made is stalagmite; but all the alabaster images of this coast are made of marble; and not of compact gypsum, which they much resemble.

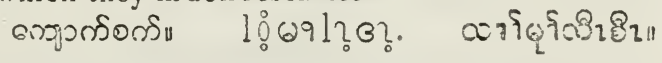

GRANULAR LIMESTONE.

This is the marble of which the images of Gaudama a:e formed, which are usually called alabaster images It is a primitive limestone which has not hitherto been found in the provinces; but is abundant near Ava

$$
\text { añongasu }
$$

\section{COMMION LMESTONE.}

All the limestone of the provinces that $I$ have met with, belongs to the older secondary formation; which prow duces what is usually denominated common limestone.

Of the specimens sent to Dr. Ure by Mr. Blundell, he said: "The limestone from Tavoy has a specific gravity of $\mathbf{3 . 7}$, and is a perfectly pure, semi-crystaline carbonate of lime, akin to statuary marble. It is well adapted to act as a flux in the melting of iron. The limestone of Mergui has a specific gravity of $\mathbf{2 . 7}$; it is a pure calcareous carbonate."

$$
\text { कำ }
$$


CALCÁREOUS GRIT.

There is a calcareous grit apparently of the tertiary formation, found on the Tenasserim in about latitude $14^{\circ}$ $20^{\prime}$. It is composed of grains of sand united by a calcareous cement. It is of a uniform grey color, and makes the best whetstones that are found in the provinces.

\section{CHALK.}

Chalk is seen in the bazars, but it does not appear to be a production of this country, being imported from Bengal.

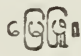

$$
\text { กงวัง ริ. }
$$

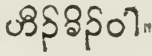

MAIL.

The soil may be characterised as marly in the neigh. borhood of some of the limestone ranges, but no bets of marl have yet been discovered.

\section{CALCAREOUS TEFA.}

Several varieties of calcareous tufa are found in the vicinity of the limestone rocks, formed by the deposition of the waters that run over them. They often contain shells belonging to existing species; especialiy Hclix. anguina, and Cyclostoma tuba.

\section{ARRAGONITE.}

Some of the cares on the Salwen furnish a species of double refractive spar, which I judge to be Arragonite.

DOLOMITE, OR MAGNESIAN CARBONATE OF LIME.

A few of the limestones in the east part of Amherst Province, Mr. O'Riley found to be magnesian carbonates; and Prof. Mitchell in his analysis of the lead ore from the Salwer-limestone found $m \nRightarrow$ gnesia among its constituents.

A limestone in Arracan, Mr.Stilson has used as a lithographic stone in a small way; but it does not do well.

$$
\infty \text { sog }
$$




\section{FLUOR SPAR.}

I have a small specimen of bluish crystals of fluor spar, which the Burman, who brought it, said was found in the northern part of Province $A$ mherst. As the mineral is often found in connection with lead, it is probable they will be found together in these Provinces.

Fluate of lime.

\section{SELENITE.}

A fine transparent crystal of selenite in the shape of a parallelopipid was brought me by a Burman, who said at was found in Amherst Province.

Crystallized sulphate of lime.

Foliated

"लिएक

\section{FIBROUS GYPSTM.}

A fine variety of fibrous gypsum is seen in some of the China shops; but it is brought, the Chinese say, from China. They use it in medicine, and say "it is very cooling"!

Sulpliatc of lime.

Sha-koung.

(Chinesc.)

GRANULAR GYPSUM.

Gypsum is found near the banks of the Tenasserim in about latitude $13^{\circ} 40^{\prime} \mathrm{N}$. It is granular and friable, and dees not correspond in appearance to ordinary specimens: but Dr Morton who analyzed it, pronounced it a decided sulphate of lime. 


\section{ACIDIFEROUS ALFALINE MINERALS.}

SALTIETRE.

Saitpetre is found in some of the carcs and is imported from Rangoon.

Nitre.

Nitrate of potash.

Prismatic nitre.

ดईะชई8n

ติง

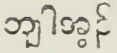

NATROS.

Natron is abundant in the ricinity of Ava, where it is used by the Burmese instead of soap, and they call it "earth soap.'

Carbonate of soda.

66) 20 S?्दि"

BORAX.

Borax is seen in the bazar but it is importec.

Borate of soda.

Tincal, (unpurified.)

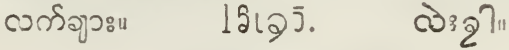

FOOCK SALT.

Rook salt is also seen among the drugs, being used by the natives in medicine.

Chloride of sodium.

Muriate of soda.

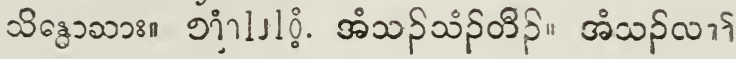

SAL AMIONIAC.

Sal ammoniac is not a product of the Provinces, but it is sold by the druggists.

Muriate of anmonia.

o.గ⿰丨丨コ

O०ईगง.

อ อิะอి 


\section{SCIDUEBOUS ALEATINO-EARTEY MIUERAIS.}

\section{ALUM.}

Alum is found in a reddish slate clay, or soft clayslate in the valley of the Tenasserim, about forty miles below Matah at the forks; this, with an indurated sand from a neighboring locality that also contains it, is the only alum that has been yet met with in the Provinces.

Sulphate of alumine and potash.

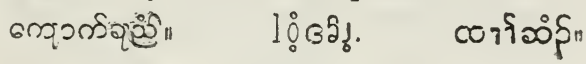

\section{ALKALINO-EARTHY MINERALS.}

\section{MICA.}

Mica is found in the mica slate and granite, but has not been met with in large plates on this coast, though such are sometimes seen for sale in the bazar. It is usually white, but black mica occurs in the granite of Double Island. It is often by a misnomer called talc.

coşि:

\section{FELSPAR.}

Crystals of felspar abound in the granite, and where it is porphyritic as on Double Island, and on the islands opposite Yay, they are sometimes quite large. It is usually white, but the granite at the mouth of Tavoy river, on the east side, is studded with beantiful crystals of flesh. colored felspar.

\section{MOON-STONE.}

Some of the "cat's eyes" that are brought for sale by the Ceylonese, are made of adularia or moon-stone, a variety of felspar found in Ceylon resembling opal. In Europe it is often sold for opal.

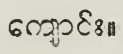




\section{SOAPSTONE.}

Soapstone, potstone, or steatite, is constantly for sale in the stalls, being used by the Burmese to write with on their blackboards, as Europeans use chalk. It is not however a production of the Provinces but is imported from Burmah, where it is abundant.

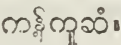
งซวำ. งซำ?
טחి"

\section{CHLORITE.}

Grains, or lamina of chlorite ore found in connection. with tin; and portions of the beds of clayslate east of Tavoy, contain chlorite slate.

$$
\text { anjorरucon }
$$

SCIIORL.

Schorl, or black tourmaline, is found in quartz near the mouth of Tavoy river on the east side, and also at the foot of the eastern mountains, near the head waters of the Dahgyaine, north east of Maulmain. These are the only localities where I have met with this mineral. In both, the crystals are numerous, and in Taroy they are large, but not so handsome as seen in foreign specimens.

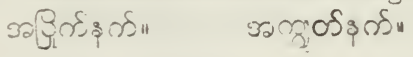

GREEN TOURMALINE.

A green jewel that cannot be distinguished by the eye from beryl, is brought with the Ceylon diamonds; it is however, grcen tourmaline; as may be ascertained by a very simple test, for beryl scratches quartz, but tourmaline is scratched by quartz.

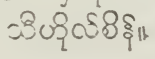

C'EYLON DIAHONDS.

White jewels of an inferior quady are often offered for sale in Naulmain under the name of Ceylon diamonds, but they are usually made from green tourmaline. White tourmaline, is a rare mineral, but the green variety being common, the jewelers by exposing it to heat expel ita color and it becomes white.

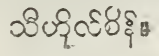


YELLOW TOURMALINE.

Among the Ceylon diamonds that are seen for sale in Maulmain, is a yellow jewel resembling a topaz; but which I find on examination to be yellow tourmaline.

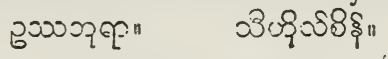

WHITE TOURMALINE.

An occasional crystal of white tourmaline is seen ainong the crystals of the black variety in specimens from the Shan states; but I have never met with it in the Prosinces.

Indicolite, white variety.
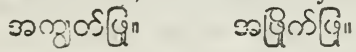

RED TOURMALINE.

Red tourmaline is found in Burmah, though it is not seen here. Jameson says the king of Ava gave a specimen to Symes which was valued at five hundred poundo in England.

\section{Rubelite. \\ Tourmaline rubelite, $8 \S \xi$}

MACLL.

In the slate strata near the granite east of Tavoy, arc numerous crystals of what Hitcheock calls andalusite macle; because with many other mineralogists he thinks andalusite, and chiastolite or macle, one species. The crystals are very small, but exceedingly numerous. Occasionally their rectangular ends are marked with the Greek Chi, or English X, from which they are called chiastolite; but more frequently the $\mathrm{X}$ is wanting. It is much softer than either andalusite, or chiostalite, as described in works on mineralogy, but it is quite as hard ay are specimens which $I$ have received from America.

It must be a very rare mineral in India ; for the Curator of Mineralogy and Geology, of the Asiatic Society's Museum did not recognize it as any mineral with which he ras acquainted; and other Indian geolngists, and miner. 
alogists have been equally puzzled with it. 'There can be no mistake however, in the identification, for I have spe. cimens before me, labelled by one of the first mineralogists in America, differing in no important respect from the Tavoy mineral.

\section{METALIFEROUS MINERALS.}

\section{PLATINA.}

Dr. Royle says that platina is found in Burmah; but on what authority? Captain Glorer had a specimen which he obtained from a priest in Tayoy, that he thought resembled platina more than any cther metal; and I had a specimen of a Tavoy mineral with the general aspect of platina, which occasioned me no little perplexity, until I found that it was a mixed metal formed of silver, bis muth, zinc, and some other things to aid the alchemists in their search for " the philosopher's stone."

\section{GOLD.}

Though not quite so abundant as in California, yet there is perluaps, no mineral except iron, more uriversally diffused over the Provinces, than gold. It is found in the lead near their northern boundary, it is washed from the sands of the Tenasserim on the south, and the streams, that tumble from the high granite mountains between Yay and Monmagon, are coustantly 'rolling down their golden sands' into the valleys around. It has been collected, in small quantities in the tin deposits east of Tavoy, Mr. O'Riley found gold in the tin from Henzai, half a degree south of Yai, and "almost all the creeks," says Dr. Helfer, "coming from the eastern or Siamese side of the Tenasserim river, contain gold. The greatest quantity is obtained close to the old town of Tenasserim where people wash it, and obtain sometimes one anna's weight each, during the rainy season."

The richest deposit of gold in the Provinces, is howerer, at the head waters of Tavoy river, where it is found in an alluvial or diluvial formation of red earth and pebbles, very 
similar to that in which gold is found in North Carolina. On the east side of the mountains at the base of which this deposit rests, "the Siamese Gorernment," says Dr Morton, "have several hurdred men permanently occupi. el, each of whom it is said, is expected to deliver one ticka! (about one rupee and a quarter) weight of gold dust per annum. - The Burmese authorities in former times also employed people in this work at the streams on our side of the boundary, but though the quantity then procured was greater than at present, this does not appear to have ever been considerable. The method adopted is that of digging a longitudinal excavation in the sand, and washing from time to time the deposit found therein."

Three or four years ago, the head native officer in Tavoy made an experiment at "the diggings" on Tavoy river, and by the washings of nine days, obtained gold to the value of about ten rupees. This gold appears to contain a considerable proportion of silver. Mr O'Riley says that the Assay Master at the Mint in Calcutta reported it

$\begin{array}{lr}\text { Gold. } & 8 \% .895 \\ \text { Silver. } & 9.211 \\ \text { Base metal. } & 2.864\end{array}$

$100 \cdot 000$

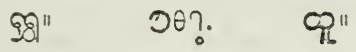

MERCURY.

Quicksilver, or native mercury, is imported from Burmah; and it is said to be brought to Ava from China.
Q3०१:11
บวา.
nosf" טी९๐"
(Pali.)

CINNABAli.

Manufactured cinnabar is found in all the bazars, but it is imported. The native doctors use considerable to salivate their patients, which they do most effectually by causing them to inhale its fumes. The Burman name appears to be derived from the Sanscrit.

Vermilion.

Sulpliuret of mercury.

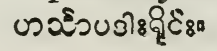
ஸวพับอา" 


\section{SIIVER.}

In the lead ore of the Salwen valley, which Dr. Morton sent Professor Mitchell for analysis, "the quantity of silver appeared to be considerable ": and in the mines north of the provinces, silver is said to be found mixed with lead. Mr. O'Riley had a specimen of an ore of silver, antimony, copper, and sulphur brought him, which produced thirtyfive per cent of silver; and the Tavoy gold, it would appear, contains nearly ten per cent of the same metal.

$$
\begin{aligned}
& \text { 68" 0า. อ. } \\
& \text { ธəs: pure silver. }
\end{aligned}
$$

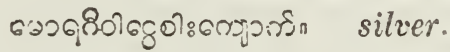

COPPER.

Dr. Helfer says: "The existence of copper on the Lampei Islands, the very first I suppose in this part of India as yet traced, is worthy of attention, and may lead to farther discovery of extensive veins of this ore."

Mr.O'Riley states, "that specimens of copper ore have been brought from several islands of the Mergui Archipelago, and all obtained appears to be of the same character, viz the grey copper ore, containing from forty to fifty parts of the metal in combination with antimony, iron, and sulphur." He has also " traced the existence of the su!phuret of copper" on the Ataran; and I had a fine specimen of the green carbonate, or malachite, brought me by a Burman who said he received it from a Karen, who represented that it was found near the head waters of the Ataran; and other natives have assured me, that the same mineral exists up the Salwen.

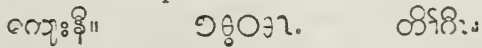

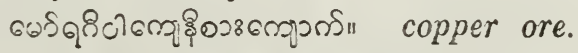

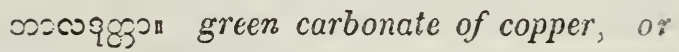

$$
\begin{aligned}
& \text { malachite. }
\end{aligned}
$$

BLUF, CARBONATE OF COPPER.

The blue carbonate of copper is seen in the same 
specimen united with the green carbonate. The natires say it is found in Province Amherst, but I have seen it only in specimens from Cheduba near the coast of Arra. can.

$$
\cos 23850
$$

BLUE VITRIOL, OT BLUKSTONE.

Blue vitriol is imported from Burmah, and seen in all the bazars, but is not a production of the Provinces.

Sulphate of copper.

१८३ว"

LEAD.

The limestone of the Provinces probably contains large quantities of lead. In the valley of the Salwen, there is a rich vein of argentiferous galena, which is reported to appear on the surface. A specimen that Dr. Morton sent to England for analysis, was said to be a very valuable mineral, and destined to make a fortune for some one. Professor Mitchell in the certificate that he furnished Dr. Morton of the analysis, says: "It contains

Lead,

Sulphur,

silver,

Grold, (traces,)

Lime, Magnesia,

Carbonic acid,

Iron,

Silica.

It is a sulphuret of lead or galena. The quantity of lead and silver appears to be considerable, but there was not sufficient of the mineral to estiniate either." The ore is seen in the limstone, precisely as galena is found in the limestone of the Nississipi, one of the richest known depo. sits of lead in the world.

Mr.O'Riley states that the carbonate of lead exists near the head waters of the Houngdarau.

$$
\begin{aligned}
& \text { ¿Q्र॥ }
\end{aligned}
$$

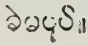

$$
\begin{aligned}
& \text { SL Od? } \\
& \text { ตริวิ" }
\end{aligned}
$$




\section{MINICM.}

Manufactured minium is seen in the bazars, but it is not znade in the Provinces.

$$
\begin{aligned}
& \text { Red oxide of lead. } \\
& \text { œईsu }
\end{aligned}
$$

\section{BISMUTH,}

Mr.Piddington the Mineralogical Curator of the Asiatic Society's Museum, mentions in his reports, that he found bismuth in one of the ores sent him from "the antimony mines" near Maulmain; and it is found in connection with silver in Burmah.

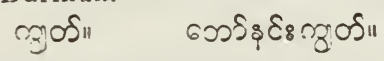

IRON.

There is a large variety of ores of iron in the Provinces, some of which are uncommonly rich in metal.

\section{COMMON BTRITES.}

Iron pyrites are very abundant in the Provinces. In some places they contain arsenic, and constitute arsenical sulphuret of iron. 'The Burmese names though usually cpplied to iron, are generic, and might be applied to any pyrites.

Sulphuret of iror.

u

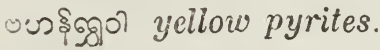

orvon_(3) globular masses containing pyrites in the centre.

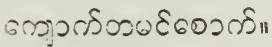

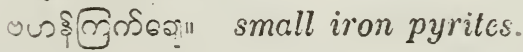

\section{IOADSTONE.}

A bout three miles north west of 'Tavoy, is a hill upwards of a humdred feet high which appears to consist almost wholly of magnetic oxicie of iron. A large rock near it" 
summit is highly magnetic, and constitutes a magnificent loadstone.

Dr. Ure to whom Mr. Blundell sent specimens of this ore reported:

"1st Compact magnetic iron ore.-Tavoy, No. 1.

"Colour iron black with a metallic glimmer, fracture fine grained, possesses magnetic polarity, specific gravity 3.511 , compared to water $=1,000$.

"It yields in analysis the following constituents :

Peroxide of iron $\ldots . . . \quad \ldots \quad 86.5$ equivalent to 60.55 metal.

Silica with a trace of phosphate

of lime, $\quad \ldots \quad \ldots \quad \ldots, \quad \ldots, \quad 3.5$

Water, $\ldots \quad \ldots \quad \ldots-\ldots 10.0$

$100 \cdot 0$

It contains no manganese or titanium.

" $\approx$ d Compact magnetic iron ore.-Taroy, No. 4.

External and Magnetic characters as abore.

Specific gravity, $3 \cdot 462$.

It yields in analysis:

Peroxide of iron ... ... ... 86.0 equal to 60.2 metal.

Silica with a trace of

phosphate of lime,

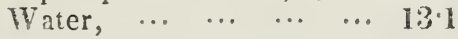

$100 \cdot 0$

It contains neither manganese nor titanium.

"3d Tavoy ore, No. 2.-External characters as above.

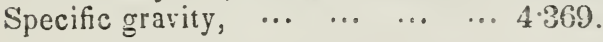

"4th Tavoy ore, No. 3.-Characters as above, as to aspect and magnetism.

Specific gravity, $\ldots, \ldots, \quad \ldots \quad \ldots \quad 4 \cdot 100$.

"The two latter samples are even richer than the former, as is evinced by the specific gravity, but they are all quite rich enough and pure enough for making the best quality of bar-iron and steel.

"I instituted two elaborate sets of experiments in search of titanium, which when present in any notable quantity 
in iron ores, renders the iron made from them red-short, but I found none in the above ores."

Octahedral iron ore.

Magnetic oxide of iron.

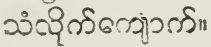

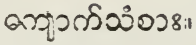

SPECLLAR OXIDE OF IRON.

- There is a very rich ore of this species on one of the braraches of Palouk river. 'The natives think it an ore of silver, and call it "the silver stone."

$$
\text { egrmprsa }
$$

BROWN OXIDE OF IRON.

Iron ore is very abundant near Nlergui, and according to Dr. Ure is brown hernatite. Of the specimens that Mr. Blundell sent him, he wrote :

"The three samples of iron ores from Mergui, are brown hematites, and from their density, will afford good iron in the smelting furnace.

Mercui iron stone No. 1 specific gravity
Ditto.
Ditto.
2
Ditto.
Ditto.
Ditto.
3
Ditto.
3.18
33.32."

$3.3 \%$

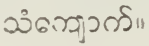

RED OCHRE.

There is a fine bank of red ochre near Kallioung on Tavoy river. It might perhaps, be turned to account in a commercial speculation. Comstock says : "It is sometimes employed as a pigment, under the name of Indian red; but more commonly, it is beliered, under that of Spanish brown."

$$
\begin{aligned}
& \text { Ochery real oxide of iron. } \\
& \text { 6ढ़ร" } \\
& \text { ก } 20010 \text { ธา. }
\end{aligned}
$$

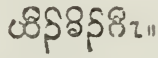

CLAY IRON STONE.

Several varieties of clay iron stone are seen in the Proyinces, among which, the nodular variety is common. Argillaceous oxide of iron. 20.rponsu 
BOG IRON ORE.

Bog iron ore is very abundant in the provinces, and in many places is quite rich in metal. It occasionally contains vegetable petrefactions, some of which have the form of branches of trees, but are wholly composed of iron ore, and which the Burmese call

बĞว

COPPERAS.

Copperas, or sulphate of iron, is often formed from the decomposition of pyrites or sulphuret of iron, forming an effiorescence on the rock that contains them.

sulphate of iron.

ว่) 0 388

TIN.

I'in is abundant in the Provinces, commencing from the mountains in which T'avoy and Henzai rivers have their rse, the northern limit of tin in the Provinces, to the southern boundary of Mlergui, Palschan river. 'The richest locality in the province of ' $\mathrm{Tavoy}$, is nearly opposite the city of Tavoy on the eastern side of the mountains.

That large quantities of tin must have been found in Tavoy three hundred years ago, we bave cridence in an incidental remarls from Mr. Ralph Fitch; who, says Mr. Hough in the Maulmain Chronicle, "trarelled in this part of the world in about the year 1586 , or $158 \%$." He says: "I went from Pegu to Malicea passing many of the sea ports of Pegu as Martaban, the Island of 'Tari whence all India is supplied with tin, 'Tenasserim, the island of Junkselon, and many others."

Captain Tremenheere found the richest deposit of $\mathrm{kn}$ in the Provinces, at Kahan on Mergui Island, about eleven miles above the town, and near the Tenasserim river. "Kahan itself," he writes, "is the highest portion of a low ridge of hills, not more than 200 feet above the level of the river: it is composed of a soft friable white sandstone rock, the upper portions of which are decomposed and irregular. 'The surface gravel does not eontain tin. It is found in the crystallized form inter- 
spersed in decomposed granite, furming a rein about three fee wide, which is enclosed by the white sandstorie rock, and dips down at a high angle with the horizon.

"Large scales of chlorite occur with it, which, as they are cenerally found where the tin is most abundant, is called by the ratives 'the mother of tin.' The face of the hill is m one spot scattered over with these, which appear t.) have been brought down from the rein with other matter from rhich the tin has been separated by the usual 1.odi of wasling. It will be noticed, that the gramte is umpletely decomposed, and that the crystals would be faily separated by washing. No in has been raised sere since the country carre into our possession, but the incality las been known. It was worked during the Bura)ese rule, and valued as supplying the richest ore of thi. 1 Burrese residing near the spot, pointed out the plnce where his operations had ceased. He had followed the Atrection of the rein alluded to, as weil as he was able, and had driven a gallery under ground in an inclined diAfctivil uprards, till the bank above fell in, when the 3.111 v was abandined. He stated that he had procured consideruble puntities of tin daily, and that he often foum it in large masses nixed with yellow ground. ATriring at the spot where his work had terminated, I sot ficple to cxcarate and find, if possible, the rein which hart been described. It was reached after about two hours? $1 \lg$ rug , at the depth of five feet from the surface of the cut in the hiil in which we stood. In about a quarter cf an hour, a fow baskets of the decomposed granite were remored down the hill, from which an amount of the crystallized peroxide of tin, equal to 63.176 grains of pure $t i n$, were collected.

"The crystallized form in which the ore is here found renders its separation extremely easy, and the whole processes of stamping and dressing, which in England are tedious and expensive operations, can thus be dispensed with. No arsenic or sulphur being mixed with the ore, it need not be roasted before it is placed in the furnace."

This ore he adds, as quoted by Mr. O'Riley, "contains specinens of macled crystals, which in weight and size 
surpass any thing I have ever seen in Cornwall, or in cab. inet specimens. Specimens have been extracted of great weight and richness, consisting of large macled crystals of tin on quartz, and contain more tin in proportion to the bulk than any specimens 1 have before seen. The largest, which measured about fourteen inches square by twelve deep, was so heavy, as to require some exertion to hold it steadily in both hands."

In another report, Captain Tremenhere writes: "With the view of ascertaining its value in the home market, I transmitted, a box of average samples of the ore, to a smelting establishment in Cornwall, (Messrs. Bolitho \& Co.) having extensive connection with the tin mines of that country. In April 1843, Mr. 'Thomas Bolitho informed me that-' The samples of once-washed ore produce about 70 per cent. of tin, and the twice-washed yields nearly 75 per cent. The metal is very good, being almost free from alloy; some of the samples which have been sent to me from the Malayan peninsula contain titanium. The ore appears to separate from the matrix very easily.

'The consumption of tin throughout the world increases so slowly, and the supply at present being more than equal to the demand, there is little inducement to speculate in tin mines.

'The produce of Cornwall is 6,000 tons per annum, and we calculate that the quantity produced at Java together with what is raised in the Malayan peninsula, will rather exceed the produce of Cornwall. The arerage price of tin in Cornwall has been about $7 \% s$. per cwt., but it is now as low as $56 \mathrm{~s}$, which is the present price of the best Straits tin, and tin mines are suffering greatly from the depreciation in the value of their metal.

"It may serve for your guidance to know, that at this moment tin ore of the description of the sample twicewashed, would fetch in England about $£ 46$ per ton.'

" The following calculations of the probable result of a shipment of tin ore, and of the metal, have been obligingly made for me by two mercantile gentlemen of Maulmain. They are based on the lowest prices which, according to 
Mir. Bolitho, were obtainable in the market in April 1845, and show a probable profit on tin ore of $7 s$. 8d. per civt. ; but a loss on shipment of the metal of $12 \mathrm{~s}$. $4 d$. per cwt. in one case, and $4 s .9 d$. per cwt. in the other.

"July 1S43. Tin ore from Maulınain purchased at 45 rupees per hundred viss, equal to 365 lbs.

$45 \mathrm{Rs}$. per $\%$ viss=per cwt. 14 rupees, or 0 25 0 Charges. E. s. d.

Duty, $0 \quad 30$

Stout boxes and shipping charges in Naulmain,

Freight home $£ 2$ per ton, $\cdots \quad \ldots$ Insurance $2 \frac{1}{2} \%$ on $40 s$.

010

Commission and London charges

$5 \frac{1}{2} \% \quad \ldots \quad \ldots \quad \ldots \quad \ldots . . .$.

Interest commission $5 \%$ on pur-?

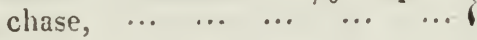

020

010

022

$\begin{array}{llllll}0 & 1 & 2 & 0 & 10 & 4\end{array}$

0334 .

Sale price per Mr. Bolitho,

0460

Leaves a profit per cwt.

$7 \div 8$

July 1843. Tin from Maulmain purchased at $7 \%$ rupees. per hundred riss.

77 Rs. per \% viss. $=23$ Rs. 14

annas or per cwt. ... ...

Charges. $\quad$ E. s. d.

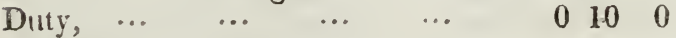

\&. s, d.

In Maulmain shipping, \&c. per $\} \quad \begin{array}{llll}0 & 0 & 6\end{array}$

Insurance $2 \frac{1}{2} \%$ or $6 \% \quad \ldots \quad 001 \%$

London charges, viz. commis- $\}$ ef

sion $2 \frac{1}{2} \%$ Ware-house and $1 \frac{c}{\circ}\left\{\begin{array}{lll}0 & 3 & 3\end{array}\right.$

Dock dues $1 \frac{1}{2} \%$ other inci-
dental expences $1 \frac{1}{2} \%$

$047 \quad 9:$ 
Interest on Purchase.

Six months @ 5 per cent.

Freight@£ 3 per ton, ... ...

Sale price per Mr. Bolitho, ...

Leaves a loss of per cwt.
$£$ s. d. $£$ s. $d$.

$\begin{array}{lll}0 & 2 & 4\end{array}$

$\begin{array}{llllll}0 & 3 & 0 & 0 & 20 & 7\end{array}$

$068 \quad 4$

$\begin{array}{lll}0 & 56 & 0\end{array}$

$0 \quad 12 \quad 4$

Another calculation of November 1814.

R. A. P.

Usual cost of tin in Maulmain, Rs.

$77-8$ per 365 lbs., or Rs.

Freight to England @ $£ 1-10$ per

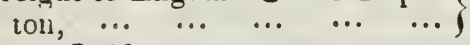

Duty, @ 10s. ... ... $\ldots \ldots$

Shipping charges here and in Lon-

don, $\ldots$...

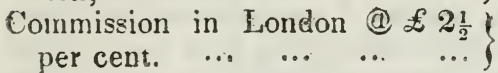

2352 per cwt.

$\begin{array}{lll}0 & 120\end{array}$

$5 \quad 000$

$\begin{array}{lll}0 & 8 & 0\end{array}$

0130

$30 \quad 6 \quad 2$

\&.s. d.

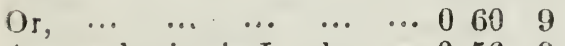

Assumed price in London, $\cdots \quad 0 \quad 56 \quad 0$

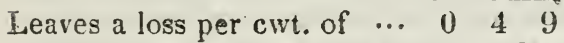

"The assumed rate for the ore at Maulmain, 45 rupees per $365 \mathrm{lbs}$., would be I thirk subject to a reduction; but that for the metal, is probably the lowest average. It will be observed also, that the London price of $56 \mathrm{~s}$. per cwt. is taken at a period of great depression in the value of the article which had averaged $72 s$. per cwt.; but it would nevertheless appear, that to send it to England in the state if clean ore would be by far the safest investment."

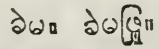
SL. Jljs. $\varphi^{\delta} \mathrm{n}$
- भु०
-as tin and zinc.
20ํ. tinned iron plates. 
ZINC.

In a broken boulder that a native brought me at Tavoy, was a large vein of some ore, that $I$ judged to be black blende, or black sulphuret of zinc. I was never able however to ascertain the locality whence it was brought. Dr. Helfer reported the existance of ores of zinc on the Mergui Islands. He says: "The other ores discovered are of less importance. They are arsenic and zinc. The latter may contain some silver."

$$
\text { iुs: }
$$

MANGANESE.

Captain Tremenheere has given a full report on the manganese of Mergui, on the 'Tenasserim; and I have seen specimens of manganese mixed with iron from one of the islands south of Mergui.

Captain Tremenheere wrote : "During my stay at the Tenasserim coal basin, a piece of manganese ore, (black wad), of good quality, was brought to me by a Karen, who stated, that it had been found accidentally in the bank of a stream called the Thuggoo, which enters the Great 'Tenasserim, seventeen miles below the coal site. Subsequently, several other pieces of the same ore were brought to $\mathrm{MIr}$. T. A Corbin, Assistant to the Commissioner from the Therabuen river, five miles above the Thuggoo, and from an intermediate spot, the locality of which had been previously known, and had been, I beliere, originally pointed out by Lieutenant Glover of the Madras Army.

"In proceeding down the river, I visited these spots, and found at each, that a valuable bed of manganese ore existed close to the surface of the country. It had been apparently cut through by the action of the stream and river before mentioned, leaving a section of the bed of ore in their banks, covered only by the debris of the banks themselves. Large quantities night have been carried away, but a few hand specimens only were taken, which sufficiently shew the nature of the deposit, and are fair samples of what might be easily collected.

"Of the extent of these manganese beds it is difficult to pronounce. The face of the country in which they are 
situated is flat, thickly orerspread with soil, and with the densest jungle. It is not, as far I could perceire, intersected by many streams which would afford the means of tracing the mineral deposit. The Great Tenasserim ri. ver has passed through the manganese bed in cue spot, $2 \frac{2}{2}$ miles removed from two other points at which it occurs to the north and south, at both of which it is likewise discorered near the surface by the action of the streams 'Thuggoo and Therabuen. 'The probability therefore, is, that it is an horizontal deposit corering rualy square miles. But without indulging in conjecture. there is sufficient at the lecalities referred to, to indicate large quantities of manganese ore which coutd be collect. ed by penetrating through the soil lying above it, and immediately near the spots in which it is now exposed to the day.

"It occurs in the form of the blact oxide, and is the manganese of commerce. It is largely consumed in Europe in the preparation of bleaching compounds, and when pure, is valuable to the manufacturer of glass.

The soft black ore, No.1, is a hydrate of the peroxide cf manganese, lnown under the mame of wad. It con. tams of water two equivalenis, or 29 per cent.

Iron, $1.96 \mathrm{grains}$ by analysis; its specific gravity is 1.47 . The specific gravity of the grey peroxide, No. 4 , is 1.46

\section{MOLYEDENA.}

Br. Pidaington, in analyzing the ores of antimony iclud " in ore instance a trace of molybdena."

\section{ANTIMONY.}

The sulphuret of antinony, appears to be a rery abun. dant mineral in Province Amherst. It is reported as being often met with on the mountains, that bound the valley of the 'Thoungyeen, Mr. O'Riley found it at the sources of the Ataran, and large quantities of the ore have been dug up in the neighborhood of Maulmain ; but there was no demand for it in Calcutta whither it was sent, and cperations have been suspended.

Mr. Piddington made the following report on specimens of the ore that were sent hial "We receired 
some time ago from Messrs. Fowle and Lonsuale of Maulmain, a box containing upwards of thirty specimens of Ores from the Antimony Mines near that place, with a request that they might be examined, their desire being of course to ascertain carefully and certainly, it they contained any, and what, proportion of the precions metals. One of the Ores sent up was indeed a "supposed antimonial silser.'

"Now, in complicated ores of this description, this sort of examination requires great care, time, and of ten repeated analysis, before a negative can safely be pronouncer from a small specinen, to assure the miner or smelter who works on a large scale that nothing of value exists 11 his ores, and these references have thus occupied a rery considerable portion of time and labor, and as is often the case in such inrestigations, have proved wholly unfruitful. Antimony, iron, arsenic, and sulphur with bismuth, and in one instance a trace of molybdena being all which can be discorered in them. The results have been sent to Messrs. Brightman, but are not worth detailing or printing. "I have suggested however, to these gentlemen that they may find it well worth their while to sink a shaft "for a change of ores.' As I now understand their operations, they seem to be occupied with what one might call mere surface-digging rather than mining, and the pronouncing, as we must now do, that these ores contain nothing of ralue, is not to be understood as saying that the locality contains nothing, but merely that the ores at the surfuct have not been found valuable; which in Cornwall, and I think in Germany, is often thought to be a favorable indication."

$$
000006 \text { Gु० }
$$

ARSENIC.

Dr Helfer reported the existance of ores of arsenic on the Mergui Islands, Mr. Piddington found it in the antimony ores, and Professor Mitchell also found arsenic in the lead ore that he analyzed. 
OXIDE OF ARSENIC.

This is the common arsenic of the shops, and is importo ed from Bengal.

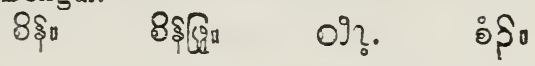

RED ORPIMENT.

Red orpiment, or realger, is found in great quantites in Burmah, and is constantly seen in the bazars.

Red sulphuret of arsenic.

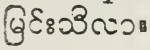

YELLOW ORPIMENT.

This is also a production imported from Burmah, which has not been found in the Provinces.

Yellow sulphuret of arsenic.

$60083 \$ 80 \quad 60083 \$ 36$ g0ी

TUNGSTEN.

'The cungstate of iron, or wolfram sand, much resembles in, and it is found in most neighborhoods where that ore is obtained, and for which it is often mistaken. One of the Assistant Commissioners at Mergui a few years ago, reported several valuable deposits of tin, not before known, and he raised furnaces on the ground to smelt the ore; but although he tried hard, and increased the heat to the highest point he was capable of doing ; still the ore remained refractory, and would not furn into tin. He attributed the fault to his furnaces, and came away with large specimens of his tin ore, which proved on examination to be tungsten, or wolfram sand. A magnet will distinsuish the two ores at once, for the iron in the tungstate of iron is attracted by the magnet, while the tin is not.

ेेंख्य०॥ 


\section{CONBUSTIBLE MINERALS.}

SLIPHCR.

Sulphur exists in the ores that are found in the forms of sulphurets; as the sulphuret of iron, the sulphuret of antimony, the sulphuret of lead, and the sulphuret of copper; but natire sulphur has not been found in the Provinces.

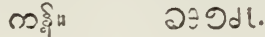

$$
\begin{aligned}
& \text { लิรควารั }
\end{aligned}
$$

\section{DIAMOND.}

Although the diamond is not found in Burmah yet it forms one of the nine gems, which worn together in a ring, are supposed to protect the wearer from evil. They are

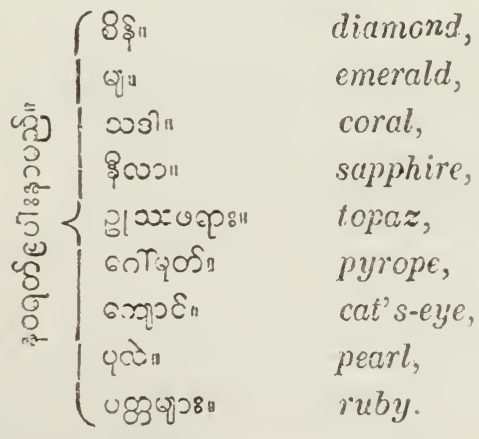

TREISENIEERITE

According to the analysis of Mr. Piddington, Curator of the Museum of Economic Geology in Calcutta, these Provinces contain a new carbonaceous mineral, which he has named Tremenheerite. In his report, he writes:

"This substance was sent to the Museum from Tenasserim by Captain Tremenheere, as black wad, but is contains no trace of manganese. 
"It is, when fresh, in masses of a scaly structure and of a deep black colour, with a highly metallic lustre, much resembling coarsely foliated graphite; after a few months it partly falls to powder, or rather into scaly flakes, evidently from the decomposition of pyrites, of which it contains three per cent. It powders easily, but the powder is always scaly, soiling, greasy, and glittering, like graphite. If the pulverised part be washed and ground, the tougher metallic looking scales remain as a black micaceous residuum, and it is only after long rubbing and washing that they also are pulverised, showing great toughness in the compacter and larger scales of the mineral. It soils much, but is too soft to mark with, nor can any very determined streak be made; what is so, is of a deep black. When heated a little sulphur sublimes; the mass burns but very slowly indeed, reddening only at first and for a long time like some varieties of graphite, and requiring a good supply of air to the crucible and constant stirring to effect its combustion.

"With patient attention the whole is burnt, with the exception of a small residum of a very light, and bright fawn-coloured powder, which is a mixture of oxide of iron and silex.

Its composition is found to be in 100 parts.

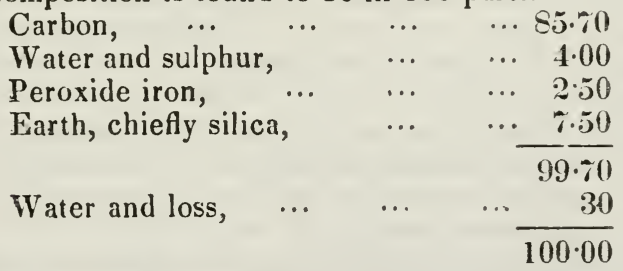

'This mineral then, differs from the anthracites in its high lustre, scaly structure, and ready pulverisation, by which it approaches the graphites; as well as by its iron and very slow combustion; but then from these it differs by its streak, and high combustibility with nitre; for, like coal and the anthracites, when projected upon melted nitre it deflagrates, heating the crucible instantly to redness, while the graphites not only boil but heat the crucible also, and 
seem but partly and very slowly to part with their carbon till a much higher heat is given.

"This distinction I have not yet found noticed in any chemical or mineralogical work, but it seems to me to be no bad test by which to separate the graphites from the anthracites; namely, that with nitre, at a heat a little above its melting poirt only, the former melt and are consumed, while the latter, defiagrate and almost explode. My trials were made with graphite, from Borrowdale from Cochin, and from the Himalaya, all of which, as above stated, diffused themselves oter the nitre and were consumed gradually, while Newcastle coal, American anthracite, and our present mineral deflagrate smartly.

"It is usually taken, on the authority of Berzelius, founded on Karsten's researches, that the iron in graphite is a mere fortuitous mixture; but Beudant acutely says, alluding to this, that ' when the iron is wanting we have no graphite, and when this substance is found in our furnaces, the proportions are sensibly the same,' i. e. about $\mathrm{S}$ per cent. which he seems to think may be the true proportion. I do not advert to Kirwan's experiments, which were merely relating to coal, and not to coal and graphite in comparison with each other.

"In Professor Vanuxem's experiments (Phil. Mag. for September 1845) the quantity of manganese and iron in anthracites is stated to be from $0 \cdot 2$ to $7 \cdot 10$ per cent. and the water from 1.90 to 6.70 . In the graphites he found from 1.40 to 3.60 per cent. of oxide of iron and manganese in the pure, and $\mathbf{2 0 . 0 0}$ per cent. in the impure kinds; and of water from 0.60 to 1.23 in the pure, and 5.33 per cent in the impure kinds.

"It may then be a mooted point to which of these two classes of the anthracince our mineral belongs, but as I have found nothing of the kind described before, I have given it a distinguishing name to be adopted or rejected, as better authorities shall determine."

It appears to be an abundant mineral in the Provinces, there being several localities where it is found in the vicin. ity of both 'Tavoy and Maulmain. 'The Burmese ofter mistake it for coal. 


\section{ANTIIRACITE.}

No indications of bituminous coal have been found in Maulmain Province, but there is reason to believe that anthracite exists under the town of Maulmain itself. In digging a well on one of the Baptist Mission compounds, beneath several alternating beds of sandstone and slate, or shale, more than twenty feet below the surface, beds of carbonaceous matter were reached. One thin bed contained Tremenheerite, which, from Mr. Piddington's analysis is nearly allied to anthracite.

Another thin stratum consisted principally of sand and carbonaceous matter, and similar beds are said to accorn. pany the anthracite of America. Below this, is a stratum of shale and carbon containing fossil plants. One was decidedly an impression of a part of a leaf belonging to the palm tribe; and others unquestionably fern leaves such as indicate the anthracite coal formation in America. One of the ferns, and apparently the most numerous one, cannot be distinguished from specimens of Neuropteris Scheuchzeri from the anthracite coal mines of Rhode Island, and Massachussetts in my possession; and others bare a strong resemblance to Neuropteris and Odontopteris of the American anthracite coal fields that have been figured, but not described.

These are the only impressions of ferns that have ever been discovered in the Provinces; but from the bottom of a well deepened last dry season on the margin of the north west corner of Mr. Paterson's compound, an abundance of Tremenheerite was brought up, and it is very probable that the fossiliferous strata are below it; though not the same as those on my compound, the inclination of the strata showing that they are above them.

I have also noticed indications of Tremenheerite in the old piles of rocks brought up from a well within Mr. Paterson's grounds at the same corner; and from Mr. Hough's description it would seem that he came to similar strata at the bottom of his well. 
MINERAL COAL.

'The Mergui coal is regarded by the Coal Committee as true mineral coal, but of inferior quality. A similar coal is found on the banks of the Tenasserim north of the latitude of Tavoy; but Capt. Tremenheere regards both as superior varieties of lignite, and it is believed correctly.

"Lignite or brown coal," says Hitchcock, " appears to be peat which has long been buried in the earth, and has undergone certain chemical changes, whereby bitumen has been produced. Bituminous coal is probably the same substance, which has been longer buried in the earth, and has undergone still further changes." The coal of the great Tenasserim valley appears to have been so long buried in the earth, that the best parts of it are better than ordinary lignite and equal to the inferior portions of bituminous coal, which is true of beds of lignite in other parts of the world.

On the banks of the Little Tenasserim, coal of a superior quality is said to exist, and in that direction further examination ought to be made. Of that section of country I have no knowledge from personal observation, but the Coal Committee say : "Eighty miles from Mergui inexhaustible beds of coal of an uniformly good quality occur on the Thian Khan, one of the main branches of the Little 'Tenasserim. T'he various beds appear to be what is called cannel coal, remarkable for consisting of upwards of 50 per cent of bitumen, which, to use the words of Mr. James Princep, shews it to be a superior blazing material, which is the main point in getting up steam."

Coal has also been found on the banks of the Lenhea river, south of Mergui; but of this nothing is known. It is a field $\mathrm{fcr}$ examination.

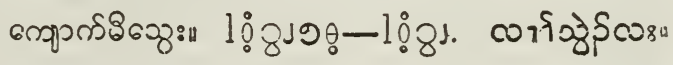

LIGNITE.

Lignite, or brown coal, has been found in sereral localities. On the banks of a small tributary of the Tenasserim, in about ten miles of latitude north of Tavoy, trunks of trees changed to lignite may be seen in the stiff clay, 
and near them the trunks of other trees completely silici. fied, and turried to stone.

There is a great variety in this wood coal, both in its appearance and chemical arlalysis. Dr. Goodall, to whom I subjected specimens for analysis, wrote: " 100 parts contain,

$$
\begin{aligned}
& 59 \text { carbon, } \\
& 29 \text { bitumen, } \\
& 19 \text { ashes. }
\end{aligned}
$$

\section{0}

The specimen was not good. Is it wood coal ?" When Mr. Blundell saw several baskets of the coal that he had liad brought in, he said it looked exactly like the first that was brought him from the Mergui coal field. This must be the coal referred to by the Coal Committee in their report for 1841, in which they say: "More recently, excellent specimens of coal have been presented to the Committee by Mr. Blundell, the Commissioner of these Provinces, as found somewhere on Tavoy river." No coal has been found on Tavoy river, and as this was the time when Mr. Blundell obtained the specimens of this lignite from the 'Tenasserim, there is doubtless an error in the reference to the locality. The Committee call it "Cannel coal," which only proves that lignite is sometimes "a perfect mineral coal;" for that this coal is lignite, no one will question who has risited the locality.

The Committee also reported on a specimen of coal from Maulmain as "Cannel coal," but Mr. O'Riley who visited the locality whence it was said to have been brought, says that if found in that neighbourhood, it must be lignite.

Dr. Morton recently furnished me with specimens of lignite collected by the commander of the surveying ressel on the coast, below Amherst. As the shore there for many miles is covered with laterite, it is probably found in that rock. Lignite occurs in laterite on the other coast.

Mr. O'Riley found lignite near the head waters of the Ataran. He says: "Approaching the head waters of the Ataran Rirer where the strata are considerably elevated, 
with the dip at an angle of $38^{\circ}$ two separate lines of lignite occur in a coarse sandstone conglomerate with shale and a semi-indurated blue clay containing limestone pebbles. This lignite is highly pyritous, its decomposition affording a copious deposit of sulphate of iron which covers the exposed surface with a dirty-colored efflorescence. Some of the pieces taken from the deposit retain their original characteristics, do not fracture, and may be sawn through in sections across the grain, the same as wood imperfectly carbonized. Other deposits of wood less charged than the foregoing are found in the banks of the rivers Dahgyaine and Gyaine, some 20 to 30 miles to the north east of Maulmain, covered with the same blue clay as thät already noticed, but none possess any useful quality as a combustible material."

PETROLEUM.

Petroleum is always for sale in the bazars, it is not howerer a production of the Provinces, but is imported from Burmah. At one locality near the banks of the Irrawaddy there are said to be more than five hundred productive wells.

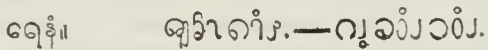

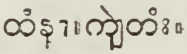

A MBER.

Amber, though unirersally used for ear knobs, is not found in the Provinces, but Dr. Bayfield described the amber mines that he visited north of $A v a$ as being in a lig. nite formation. The amber, he said, was always found amorig the lignite; and, as there are numerous localities of lignite in these Provinces, some of them, if explored, might be found as rich in amber as they are in Burmah.

Succin.

Succinum.

טดุर्षः 


\section{BOTANY.}

Half a century ago, Dr. Buchanan, who accompanied Symes in his embassy to Ava, made a large collection of plants from the banks of the Irrawaddy. $\boldsymbol{A}$ dozen years afterwards, Felix Carey, an English missionary, collected many curious and new plants indigenous in Burmah, and sent them up to Roxburgh at the Botanical Garden near Calcutta, who described them in his "Flora Indica." After the Burmese war, Dr. Wallich risited this Coast and went with Crawfurd in his embassy to Ava; and his catalogue of plants collected on this visit contains 1650 species. Eight or ten years subsequent to Dr. Wallich's visit, Dr. Griffith came to the Coast, and during a residence of fourteen months collected specimens of 1700 species of plants, growing in these Provinces.

It is not probable then, that many conspicuous plants hare escaped the notice of these indefatigable botanists; and yet, nothing was known of the pire until it was described in the Journal of the Asiatic Society, less than two years ago; and no work to which I can refer, mentions that very elegant flowering slrub, the nodding clerodendron in our indigenous flora, nor the large pink-flowered knotty cassia, nor the splendid orange-flowered buteas, nor the white-flowered drooping barringtonia with its spikes a yard long, nor the fragrant reeurved tabernæmontana, nor the curious gloriosa, nor the large blue-flowered thunbergia.

Our plants however, are better known than their pro. perties. Wallich collected specimens of a species of blumia from ' $T$ aroy, and De Candolle described the specieg as $\boldsymbol{B}$. grandis, but neither of them were aware that the weed produced an abundance of camphor, not inferior te the best camphor of the shops. Dr. Wight described 
Pterocarpus Wallichii; but did not suspect that the exudation of the tree was good gum kino; and Dr. Griffith collected specimens of Garcinia elliptica with his own hand in the province of Mergui ; and yet remained ignorant that the tree produced gamboge, which cannot be distinguished from the best gamboge of commerce.

When more attention has been paid to the geographical distribution of plants, the Tenasserim flora will probably show, that the climate of the plains on this Coast corres ponds to one on the hills several thousand feet high on the other Coast.

Roxburgh says that a species of oak, Quercus fenestra, is a native of the mountains in the vicinity of Silhet; on this Coast the same species grows indigenous not fifty feet above the level of the sea. A gamboge tree, Garcinia pictoria, grows, he says, " on the highest parts of Wyn. aad," but the same tree grows at the foot of the hills in 'Tavoy, which border on tide waters. A species of willow, he describes as "a native of banks of rirulets and moist places among the Circar mountains," but we have a spe. cies of willow on this Coast which is met on every stream before the influences of the tide ceases to be felt. The chestnut, Castanea indica, he writes, "is a native of the hilly frontier of Bengal ; "but the chestnut of this coun. try, Castanea martabanica, grows nearly down to the sea shore. Spealking of the wood=oil trees, Dr. Wight res marks: "In this neighbourhood, Madras, several species are found, but all natives of hilly tracts forming the Bala. ghaut. In Pegu, where they abound, they occupy the plains." He refers all the species of Vatica to the mountains, but we have one that drops its curious winged fruit from cliffs that overhang the sea.

Ardesia humilis is a common shrub at Taroy growing down to the plains; but its habitat on the other coast is "the eastern slopes of the Neilgheries in subalpine jungle."

Wrightca Wallichii, Wight states, is found on "the slope of the Neilgheries from about the middle of the ascent to the elevation of between 4000 and 5000 feet ;" but "the original specimens of this species were collected in the Tenasserim Provinces." 
Of the rose tribe, which includes the apples, cherries, and plums, Wight says there is not a single indigenous species on the plains of India, and that the species are "peculiarly extra tropical, a very few only being found within the tropics, and these at considerable elevations;" but on this Coast we have one indigenous species of rubus or bramble, another of cerasus or cherry, observed by Griffith; another of pyrus or pear, found by Wallich on the Irrawaddy, and if I am not mistıken I have seen a species of pygeum on a branch of the Tenasserim within a short distance of tide waters.

Many more similar facts could he easily put on record, but enough has been written, to prove that a sanatarium on Ox's Hump, a mountain four thousand feet high, fifteen miles east of Tavoy, would enjoy a climate corresponding to one six or seven thousand feet high on the other Coast. The path to its base is overshadowed by some of the most ornamental trees in the Provinces, and strown with many of our prettiest annuals, whose flowers baptize the breezes with their fragrance.

\section{SELECT ORNAMENTAL TREES AND SHRUBS.}

Perhaps no region in the world, of the same size contains a greater variety of ornamental trees and shrubs than the Tenasserim Provinces. The following selection of one hundred with a dozen palms is perhaps sufficiently numerous, yet it might be easily enlarged.

AMHERSTIA.

This is the finest indigenous tree in Chin India. It is of low stature, with slender pendulous branches clustered under its tufted summit of lively green, and draperied with large pea blossom shaped flowers of brilliant red and yellow, which hang down from its graceful arches in tassels more then a yard long.

It was discovered by Dr. Wallich on the Salwen near Trockla, and named by him after the Governor General's Lady - the Noble Amherstia. It has been introduced into England where every tree is said to be worth fifty pounds. 
When one flowers, it produces quite a sensation from the Thames to the Tweed. Since the above was in type a botanical correspondent in the North of England writes : "I dont hear whether the Amherstia which flowered near London last year is going to do so again this, but doubtless it will, and we shall soon hear of it."

"Ho, Trockla! thy tide

Hath a beautiful bride,

The child of an iris-wreathed shower;

With vails flowing down

From her emerald crown,

Whose fringes unfold

In scarlet and goid,

A glorious sight,

Ever graceful and bright-

The Queen of proud Ava's wild bower.

Tall sweet-blossomed trees

Are wooing the breeze

$\mathrm{O}^{\prime} \mathrm{cr}$ highland, and dingle, and glade,

But though they allure

With their fragrance so pure,

The Anherstia is fairest,

The noblest, the rarest;

Nor all the rich flowers

Of Albion's bowers

Can rie with its purpling shade." .

Amherstia nobilis.

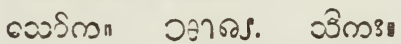

MESUA.

The mesua, which in Ceylon is called "iron wood tree," though not large, has an erect symetrical figure, whose deep evergreen foliage, flowing downward from its coneshaped crest quite conceals its bowering branches, so that when covered with its rich blossoms, with ivory-white petals, and deep yellow stamens, it looks like the royal umbrella bespangled with gold ; and the Burmese say that their next Buduha, Aree-ma-taya, will enter the divine life while musing beneath its hallowed shades, hence it is a favorite tree with the priests who plant it around their monasteries. In Sanscrit it is called nagakeshura, and Sir William Jones remarks of it : "This tree is one of the most delightful on earth; and the delicious odor of its blossoms justly gives them a place in the quiver of Camadeva, the Hindoo god of love." 


\section{To this Moore alludes in the following stanza.}

"Then rapidly with foot as light

As the young musk roe's, out she flew

To cull each shining leaf that grew,

Beneath the moonlight's hallowing beams

For this enchanted wreath of dreams;

Anemones, and seas of gold,

And new.blown lilies of the river,

And those sweet flowrets that unfold

Their buds on Camadeva's quiver."

There are at least two different species in the Provinces, H. pedunculata and $\boldsymbol{M}$. ferrea. Much confusion exists in our standand works on botany in relation to this last species. The Mesua ferrea of Roxburgh is the M. Roxbur. ghii of Wight's Illustrations; the mesua tree of Calcutta, Serampore, and neighborhood.-The $N$. ferrea of Wight's Prodromus is the $\boldsymbol{M}$. coromandeliria of Wight's Icones, and Illustrations-The $\boldsymbol{M}$. ferrea, of Wight's Illustrations, is the 11. ragaha of Gardener, the mesua tree of Ceylon; while the $\boldsymbol{M}$. ferrea originally described by Linneus is probably the species found on this coast; but for the lack of books which contain the description of Linnæus, it cannot be affirmed with certainty.

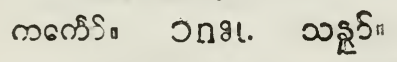

\section{NODDING CLERODENDRON.}

The Karen mountain glens of Tavoy and Mergui are embellished with one of the most elegant flowering shrubs that ever beautified a landscape-it is the nodding clerodendron. The flowers are tinged with rose, but nearly white, growing in long panicles at the extremities of the branches from which they make a graceful curve, and hang down perpendicularly from ten to fifteen inches, like an inverted cone, so that the soft greening foliage seems canopied with rosy-white vails. The flowerets are few, the divisions of the panicle being remote, and each bearing only three or five flowers. The divisions and subdivisions being all rectangular, and each blussom hanging from its pedicel like an ear drop, order and beauty are inseparable associations with this rare plant. It deserves a place in every conservatory, yet from Loudon's Enclyclopedia of plants before me, it had not reached Fingland when that 
was printed; and it is not in Wright and Eaton's Botany of North American plants, indigenous and cultivated. The shrub blooms in the dry season, and rarely exceeds in its native soil, more then ten feet in height.

Clerodendron nu!ans.

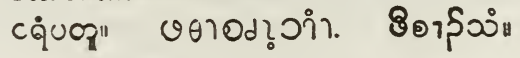

CHAMPAC.

The streets of our towns and villages are often shaded with the lofty distinguished champac, one of our few trees embalmed in song, of which the poet sings :

"The maid of India blest agairs to hold

In her full lap the Champac's leaves of gold,

'Thinks of the time when by the Ganges' flood

Her little playmates scattered many a bud

Upon her long dark hair."'

The tree is in flower or fruit a great part of the year, and its rich orange blossoms, which are exquisitely fragant, are also used by Burmese maidens to adorn their "long black hair."

It is the only representative we have on the Coast of that "Glory of America" - the magnolia tribe.

Michelia champaca.

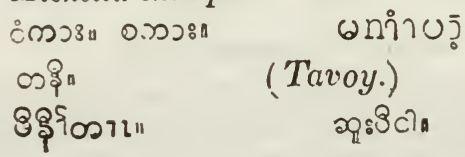

JONESIA.

When Dr. Wallich found the Amherstia, it was grow. ing beside a Jonesia, and though it be but little diffused over our garden plots, yet its symetry, and numerous bunches of red and orange flowers certainly entitle it to companionship with that celebrated tree. Roxburgh says : "When this tree is in full blossom, I do not think the whole vegetable kingdom, affords a more beautiful object."

Gaudama, it is said, was born under this tree; and within the fall of its shadow, he delivered his first harangue. "At the instant of his birth," say the Barman sacred books, "he walked seven steps, and with a voice like the roaring of the king of lions he exclaimed. "I am the 
most excellent of men. I ain the most famous of men. I am the most victorious of men."

Jonesia asoca.

KNOTTED CASSIA.

This species of cassia is remarkable for its large pinkcolored flowers, and is seen tinting the Tavoy forests almost as beautifully as the calico tree does the steeps of the Apalachian Mountains. It is highly esteemed in Bengal, but I have seen no one cultivate it in these Provinces except Major Macfarquhar, and he.told me his plants were sent him from the Botanical Garden near Calcutta !

Cathartocarpus nodosus.

Cassia nodosa.

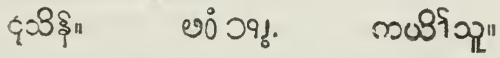

SWEET-FRUITED CASSIA.

"This tree," says Roxburgh, "is uncommonly beautifu! when in flower, few surpassing it in the elegance of its numerous, long, pendulous racemes of large, bright yellow flowers, intermixed with the young lively green foliage." It bears a striking resemblance to the laburnum.
Cathartocarpus Fistula.
Cassia Fistula.

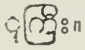
๒ว ริ.
mบ8รา1"

\section{FLOWERY CASSIA.}

Though not so handsome as either of the preceding species, the flowery cassia is extensirely multiplied on this Coast. It is a slender, graceful tree, "every branch terminating in a lorge panicle of deep yellow blossoms;" and when several are clustered together, waving their radiant glories in the floods of a noon-tide sun, they look tike illumined hills on the eve of a Burman Carnival.

\section{Cassia florida.}
วองิ"
(Bur.)

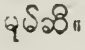
(Tavoy.) งกำ. 


\section{MIIUSOPS.}

A species of mimusops, a rare ornamental tree, is much valued by Burmese ladies for its small delicate sweet-scented blossoms, which they string in chaplets for the head.

$$
\begin{aligned}
& \text { Mimusops Elengi, }
\end{aligned}
$$

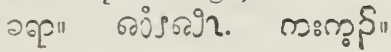

\section{BUTEA.}

There is a species of butea rery abundant in Province Amherst which is a most magnificent tree. Whe Pwo Karens plant it in their sacred groves, where the deep rich orange blossoms seen under a tropic sun in the dry season enieloping their almost leatless trunks and branches, give the copse the appearance of a burning jungle. 'I'he Burman books describe the Himalaya forest, as shining with the Howers of the butea "like a flame of fire."

$$
\begin{aligned}
& \text { Butea fiondosa, }
\end{aligned}
$$

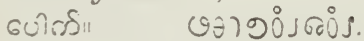

$$
\begin{aligned}
& \text { 8c8रीक: }
\end{aligned}
$$

CTEEPING BLTEA.

I"is is an immense creeper with flowers resemblung the preceding species, and is not uncommon in the pro. vinces of 'Taroy and Nergui.

Butea superba.

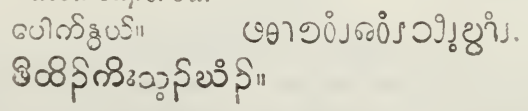

GUI KINO TREE.

The gum kino tree is a majestic evergreen, whose yellow papilionaceous flowers clustering amid the bright drooping foliage, scent the air, like the large magnolias, for several hundred yards around. It is propagated by simply planting large branches in the ground at the commence. ment of the rains. 'There are, however, two species, the rod, and the white, as distinguished by Burmese-the red 
-producing the finest timber, but the white padouls is by far the finest ornamental tree.

Plcrocarpus inticus.
ugsosn Gi:"

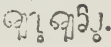

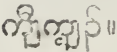

WHITE B.IUIIITA.

'This is a handsome shrub, with large blue-white flow ers. It grows rapidly from seeds, and flowers in the second or third year.

Bankinia acuminata.

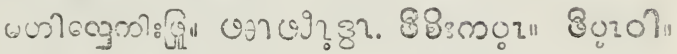

PLTPLE BAUHINIA.

When in blossom this is a very handsome tree, bearing large purple flowers.

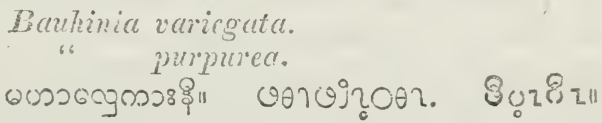

\section{IELLOW BAUIINIA.}

This shrub bears a large sulphur-coloured fiorer, and the upper petal has usually a deep purple spot on the inside.

Bauninia ímcitosa.

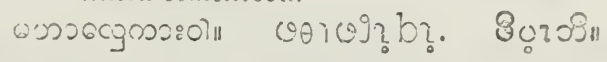

\section{CREEPING BALIINIA.}

There is a scaudent species of bauhinia that creeps up to the tops of the highest trees which has very large leares, and whose flowers have the fragrance of mignonette. It approaches Vahl's bauhinia in size and habit, but its petals are red and yellow, while in that they are said to be white. It is probably one of the species named by Wallich of which I have no description.

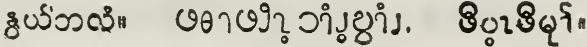




\section{ESCULAPIAN-ROD BAUHINIA.}

I have never seen the flowers of this species but they are mentioned as small. The tree is remarkable for its contorted stem, and "it is said to hare been," remarks Louden, "the origin of Esculapius' snaken rod which he brought from India."

Bauhinia scandens.

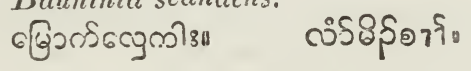

CHINA CHAMPAC.

'This is a small South American tree, called by the Burmese, china champac, whose straggling, and often leafless branches shoot out from their extremities delicate orange-colored blossoms, tinged with red, and of sweetest fragrance.

Plumiera acuminata.

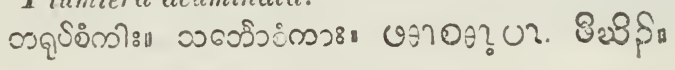

GUM ARABIC TREE.

The pretty, tall shrub sometimes called gum arabic tree in Calcutta, though not the true gum arabic plant, is a farorite with the natives on this Coast, and it grows rapidly from seeds. The flowers are deep yellow, small, in globular heads, like the mimosa, and powerfully fragrant.

Vachellia Farnesiana.

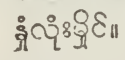

QUEEN LAGERTTREMIA.

When cultirated in England the queen lagerstrœmia is a small shrub, but here in its native soil it is a large timber tree, and when in flower is one of the most conspicuous trees in the Provinces. A tree in full blossom looks in the morning as if mantled with roses, but the flowers change through the day to a beautiful purple, making it appear at evening, if seen from a short distance, like a bower of English lilacs.

Lagerstrcemia regina.

पुर्टे"

8?

$$
\text { ว602हญ् }
$$

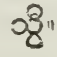


SMALL LAGERSTREMIA.

The Tavoy forests are adorred with a smaller species of lagerstrœmia than the preceding, but the flowers are equally elegant and quite as large.

Lagerstramia.

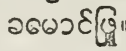
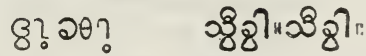

INDIAN LAGERSTREMIA.

This is a small pretty shrub, common in gardens in Maulmain, and of easy cultivation.

Lagerstramia inciica.

HENNA TREE.

This is the camphire of the English Bille, and the cypress,shrub of the Greeks and Romans. "The cypress plant," says Rosenmuller, "is held in particularly high esteem by the Greeks, the Arabs, and the Turks; and they think that they make an agreeable present when they offer a person a posy of its flowers. In reality, this plant is, as Somnini observes, one of those which are particularly agree able to the eye and the olfactory organs. The flowers, of which the coloring is so soft, spread the most delightful fragrance to a great distance, and fill with balsamic odour the gardens and rooms which they adorn." It is extensively cultivated by the Burmese, and hedges formed of it are common in Bengal.

The fresh leaves beat up with catechu,

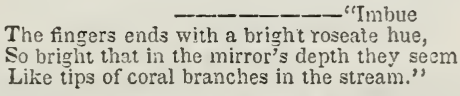

This use of the leaves is as old as the Egyptian mummies, and is still practiced by Burman females.

Lawsonia alba.

" inermis.
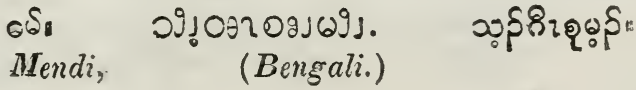


\section{SWEET SCENTED UVARIA.}

Native cottages on the Coast are often overshadowed by the sweet uvaria, whose yellow-green petals almost blend their colouring with that of the leaves.

Uvaria odorata.

usScईn

GORDONIA.

A species of gordonia is a conspicuous tree in Maulmain. It belongs to the same family as the tea plant, and the camelias of which the japonicas are such farorites, and is a member of the same genus as the American loblclly bay, and Franklinia, to which the flower bears a strong resemblance. Wallich has named our tree the abundant flowering gordonia, but there is some differcnce between the 'Tavoy and Maulmain trees; whether cnough however to constitute different species, is doubtful. The $M$ lialmain tree las leares precisely like $G$. obtusa "with shallow serratures; " but the leares of the Tavoy tree are quite entire. The Burmese have different names for them.

Gordonia fioribunda.

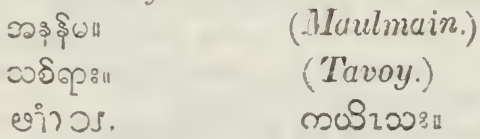

ORNAMENTAL DILLENIA.

When a stranger debarks at Maulmain in February, his attention is arrested by a tree without a leaf, but covered with large gaudy yellow flowers, it is the ornamental dillenia. Several other species of the genus are indigenons in the Provinces.

Dillenia ornata.

๑) Eुई:

$2 \theta$.

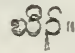




\section{WHITE FLOWERED BARRINGTONIA.}

There is a species of barringtonia in the T'avoy and Mergui jungles with drooping spikes of white flowers three or four feet long; and which would be much ad. mired if introduced into the cities. The leaves are very large and lyre-shaped, and both flowers and foliage would contrast well with the other trees around it. The species is not described in any of the books to which I can refer.

Barringtonia.

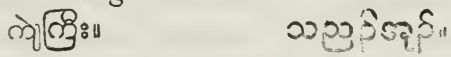

SCARLET FLUWERE B.RRINGTORZA.

This tree bears long fendulong bun hes ui scarlet flow ers, and is rery abundarie in the forests to which it is a great ornament.

Barringtonia acutangula.

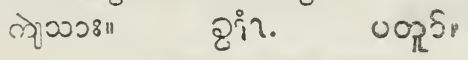

ARABIAN JASHINE.

'This jasmine is probably more universally cultirated than any other flower. 'The comm double variety is more generally seen, but the single flowered, with a twi. ning habit is not infrequent.

Jasminum Sambac.

ouvicos"

\section{Great Dovble arabian J.ISMTE}

'The rich robed branches of this variety are studded all over like the snow-drop tree with lovely white flowers, the size of small roses, and delightfully fragrant.

Jasminum Sambac, plenum. 0035000811

CATALONIAN, OR SPANISH JASMINE.

This is the most exquisitely fragrant species of the genus, and is very generally cultivated by both Burmans and Europeans.

Jasminum grcindiflorim.

Goर60\% 


\section{WILD JASMINE.}

There is a wild climbing jasmine seen throughout the Provinces festooning the forests, and arching the pathways with its delicate flowers, like a wreath of snow flakes flung over the arms of a Canada spruce.

\section{Jasminum syring afolium. ऽह8ี}

TREE OF MCERRING

The tree of mourning, sometimes called nit-blooming flower, is as great a favorite in india as in the Southern States of America. Its delicate orange and white blossoms pour the most delicious fragrance on the evening air, and then fall in showers, bedewing the earth's cold bosom with sweetness

\section{Nyctanthes Arbor tristis.

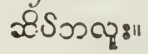

PERIWINCLE TREE.

This is a handsome shrub almost constantly corered with blossoms, that can scarcely be distinguished from the flowers of the rosy-periwincle, though of a different genus. It was first discovered in Burmah, and Roxburgh, who introduced it into the Botanical Garden, said in his description: "The flower is like those of Vinca rosea, but larger and faintly fragrant; it is in fact one of the most ornamental shrubs in the garden."

Calpicarpum Roxburghii.

Cerbera fructicosa. ocos $\mathfrak{n}$

\section{ROSA.}

The rose is quite naturalized on the Coast, and is one of the abundant flowers in the European gardens. It is cultivated by the natives also to a small extent, and the flowers sold in bazar.

Rosa.

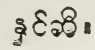


SWEET BRIAR.

Our English residences are often filled with sweet odours from the grateful eglantine, or sweet briar, but the plant is kept alive with difficulty when exposed to the southwest monsoon.

Rosa rubiginosa.

\section{PERSIAN LILAC}

This beautiful tree whose lilac clusters perfume alike the mansion of the American Planter, the saloon of the Frenchman, and the palace of the Syro-muhammedan is here also occasionally found shedding its sweetness around our Indian bungalows, and embellishing their environs. It is called in England the bead-tree, and in the United States the pride of China, or pride of India.

Melia azedarach.

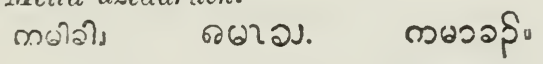

\section{INDIAN TRUMPET FLOWER.}

The large terminal erect racemes of a species of bignonia or trumpet flower, are often seen near the dwellings of the natives; and its seeds are frequently noticed on account of the large membraneous wing with which they are surrounded.

Calosanthes indica.

Bignonia

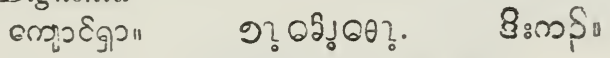

STIPULED TRUMPET FLOWER TREE.

A common flowering tree throughout the Provinces is a species of bignonia that bears a long twisted pod. It is common at Maulmain; and the flowers are often seen in bazar where they are sold for food. The tree enters the native materia medica as affording a cure for psora.

Bignonia stipulata.

Spathodea stipulata.

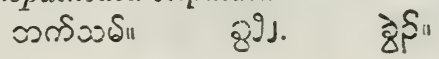


Near the Burman monasteries, a fragrant flowered species of calophyllum is occasionally seen in cultivation, and is a remarkably handscme tree. The beauty of the leaves has given name both to the genus and species-calophylum, handsome leaf, and Inophyllum, fibre leaf,: "because the middle nerve of the leaf seems to ramify into a multitude of fibres; "while the flowcrs are in elegant white bunches, and very sweet scented.

Calophyllum Inophyllum.

iृent:

IOYAL POINCIANA.

This gorgeous shrub which has been introduced from Madagascar into India, bears a most magnificent, and graceful flower; and as it flourishes well in these Prorinces, if it were generally planted in our gardens, it would add much to their beauty.

Poinciana regia.

FLOWER FEXCE.

'T'his is a gaudy ever-flowering shrub planted in Barbadocs for hedges; it is much cultirated by the Burmese, and the variety with yellow blossoms is occasionally seen in their gardens. It bclongs to the same genus as the preceding, and is sometimes called peacocli's pride, and Spanish carnation.

Poinciana pulcherrima.

$$
\text { colEq } \mathcal{S}_{u} \text { ocusoscoon (Tavo\%.) }
$$

DARK-PLRHLE PONGAMIA.

This tree is very common about Maulmain and though vastly inferior to a multitude of others, Wallich thought it of sufficient beauty, to give it a place among his splendid engravings of rare Indian plants.

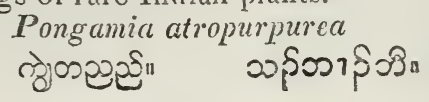




\section{CLITORIA.}

The clitoria, with its deep blue flowers, is seen tangled with other climbers wandering over trees, and arbors, in all parts of the country.

\section{Clitoria ternatea}

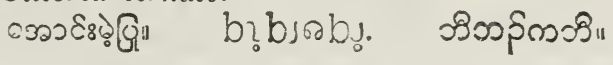

GARLAND TABERAEIONTANA.

The foliage of this tree very beautifully contrasts with its large blue-white double flowers; which are often inproperly called on this Coast, "wax flowers." The wax Hower of Bengal is a trailing creeper, Hoya camosa, which has been recently introduced into European gardens.

The single flowered variety is seen cocasionally but not often.

Tabernamontana coronaria, flora plena.

RECERVED TADERNACMONTANI.

'This is a low shrub indigenous about Manmain, remarkable for its recurved peduncles and fragrant flowers. Tabernamontana recurza.

$\cos 2000 S_{11}$

\section{ALLAMANDA.}

This is a climbing slurub, a native of South America, which produces a great profusion of yellow bell flowers. It differs in some respects from Voigt's description, and by some would perhaps be referred to a different species, but it accords very well with Lindley's in his Flora Medica.

Allamanda cathartica.

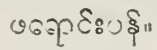

\section{SCARLET CLERODENDRON.}

'i'he Burmese compounds are ornamented with this species of clerodendron, which bears a large cone of superb scarlet flowers, and, although said to be originally from China, it appears to be naturalized on this Coast.

Clerodendron squamatum.

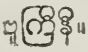

लनา8? Пगे.

ชุำตรา. 


\section{FRAGRANT CLERODENDRON.}

In the most arid parts of the forests, during the hottest months of the dry season, the path of the traveller is perfumed by the fragrant flowers of a large leaved species of clerodendron. Major $\mathbf{M}$ acfarquhar sent specimens to the Agricultural and Horticultural Society of Calcutta a few years ago, but they were unable to determine the species satisfactorily.

Clerodendron.

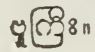
งวาฉใดวั.
ชกุุุดิ

DOUBLE FLOWERED CLERODENDRON.

The Burmese cultivate a fragrant double clerodenilron, which appears to be a variety of the last species.

Clerodendron.

รु)

งจาชใงรจัง.

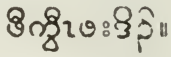

CIIANGABLE LANTANA.

This straggling shrub appears to be quite naturalized in the neighborhood of Maulmain; though rarely seen in other parts of the Provinces. The flowers are yellow when they first open out, but afterwards change to a rose color.

Lantana nivca, mutabilis.

कø दुल्र:

CHASTE TREE.

This is a shrub much cultivated by the Burmans that bears a handsome little blue flower. Both leaves and flowers are "rather agreeably heavy scented."

Vitex trifolia.

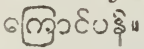

STROPHANTHUS.

There is a shrub about Amherst that bears a flower resembling the nerium, but with very long linear filaments to the end of each segment of the corolla. It is a specieo if strophanthus and well deserving of cultivation.

Strophanthus, 
PICTURE PLANT.

The justicia, one variety of which has variegated leaves, and the other deep purple, is multiplied throughout the Provinces.

Graptophyllum horterise.

Justicia picta.

'guई" variegated leaf.

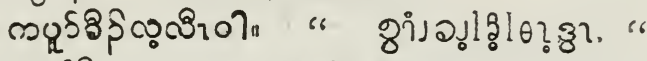

ocss\$r blood-red leaf.

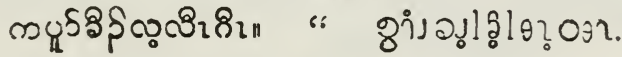

CAPE JASUINE.

Most Tenasserim gardens, as well as many European, and American, are graced with this tasteful shrub, which does not belong to the jasmine tribe, but is a species of gardenia. Its pure snowy blossoms, strongly fragrant, Loudon says, smell "like the narcissus;" and they contrast delightfully with the thick deep green foliage in which they are set.

Gardenia florida.

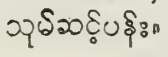

$$
\begin{aligned}
& \text { งวารง จำ. }
\end{aligned}
$$

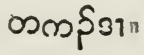

GARLAND GARDENIA.

This is an indigenous tree, which produces a profusion of flowers that are white in the morning, when they first open out, but which, on exposure to the sun, become quite yellow.

Gardenia coronaria.

बहरे०॥"

(co)ชos 29 .

$\cos \hat{6} 211$

MUSS.TNA .

A species of mussænda with corymbs of orange-colored flowers, and a single sepal expanded into a large white leaf, is not the least interesting shrub to the eye of the curious. In Calcutta an allied species is cultivated in the gardens, but its abundance in our forests prevents its introduction into European gardens on this Coast.

Mussanda Wallichii. 


\section{PSYCHOTRIA.}

The genus psychotria furnishes a handsome shrub, whose small white flowers throw a delightful fragrance on she path during a morning walk.

\section{Psychotria.}

गेวิ:

\section{(Sgau.)}

\section{CRIMSON IXORA.}

This species of ixora is very common in front plots, and is sometimes called by the European residents, "the eountry geranium."

\section{Ixora coccinect.}

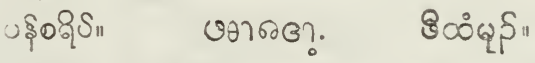

WILD IXORA.

An indigenous species of ixora is frequently met with in mountains and plains whose flowers are of a much paler hue than the preceding species.

Ixora pallcns?

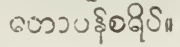
เองารงใ.
800

WHITE IXORA.

A white-flowered ixora is another of our wild thwere that ought to be brought into cultivation.

Jxora alisa.

P.IYTTA.

An indigenous species of paveita, with flowers resenbling a white ixora is found at 'Taroy.

Pavetta tomentosa.

युร

NACCLEA.

A fragrant orange-flowered species of naticlea is somefimes cultivated by the natives. Its large glossy leaves afford a thick and beantiful shade; and, in Indian Mytho$\log y$, it is one of the four shadow-giving trees that grow on mount meru-the eugenia, the nauclea cadamba, the banyan, and the peepul.

Nanslea Cadamba.
$\omega 32:$
Qj!ฺ.
బญิః॥ 
HEDYOTIS.

An attractife purple-flowered shrub, a species of hedyotis is multiplied in some sections of the country.

IIedyotis.

SAMADERA.

The low grounds near the sea coast are ornamented with a handsome shrub which is a species of samadera, and bears a rather curious flower. Like the quassia of the same tribe, its leaves are most intensely bitter, and may perhaps possess the virtues of quassia. Wight says it is cultivated in the gardens about Bataria; but I have never seen it out of its native jungles on this Coast.

S'amadera lucida.

coin

ल)ेद्ध

\section{THREE-LEATED CAPER.}

The three-leaved caper tree produces large handsome terminal heads of flowers with numerous purple stamene and white clawed petals that change to cream color.

Cratava Roxburghii.

C'apparis trifoliata.

moses" moos.n

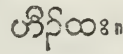

SHOE FLOWER.

This bold, flaming flower is extensively cultivated, and is a very good substitute for "Day and Martin's blacking."

Hibiscus Rosa sincnsis.
62? हดे

CHANGABLE IIBISCUS.

The double rose hibiscus whose white flowers deepen into red, are sometimes seen in the front plots of European residences.

Hibiscus mutabilis.

yoplat hibISCCS.

A yellow-flowered species has been introduced from the Madras Coast, which is quite an ornamental tree. 
Linnœus very appropriately named it the poplar hibiscus, for it has the leaves of the poplar with the flower of the hibiscus.

\section{Thespesia populnea. \\ Hibiscus populneus.}

\section{TORTUOU'S HIBISCU.}

The banks of our tide-water streams are often damasked with the changable red and yellow flowers of this large luxuriant bush, whose crooked wandering branches, crossed and locked with each other, spread along the ground heaping the earth with its evergreen foliage.

Paritium tiliaccum.

Hibiscus tiliaceus.

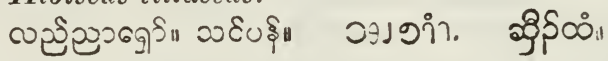

FRAGRANT SCREWPINE.

The male flowers of the fragrant pandanus or screwpine, are exceedingly fragrant, and great favourites with the Burmese. 'The palm-like shrub that bears them, dropping roots from its branches, like the banyan, is a very curious plant, and not iuelegant.

Pandanus odoratissimus.

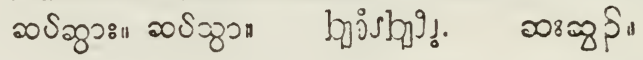

SWEET-SCENTED OLEANDER.

This well known fragrant flower adorns a few of the gardens in Maulmain, but it has not yet come into general cultivation.

Nerium odorum.

\section{SCARLET NERICM.}

European compounds are occasionally scented with this useful shrub, whose orange-red flowers have the grateful fragrance of the pine apple.

Wrightia coccinea.

Ncrium.

LAUREL-LEAVED PASSION FLOWER.

Numerous species of passion flower are seen wandering over the arbors and trellises of our sunny greens, but none 
exceed in beauty, and fragrance the laurel-leaved passion flower, called in the West Indies, water lemon vine, which appears to have been the first of the tribe introduced into Burmah.

$$
\begin{aligned}
& \text { Passiflora laurifolia. } \\
& \text { รววอว०0\%: }
\end{aligned}
$$

FETID PASSION FLOWER.

A species of passion flower with foetid flowers, but ve. ry elegant moss-like involucres, though rarely noticed in gardens, may be often seen creeping over the hedges in Maulmain like an indigenous plant.

Passiflora fatida.

\section{MUSK PLANT.}

One of the most gaudy flowering shrubs in the country is the musk plant, whose large yellow blossoms with blood colored eyes are sometimes seen bedecking Euro. pean grounds, and whose seeds have been said to be an antidote to snake bites.

Abelmoschus moschatus.

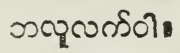

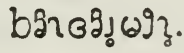

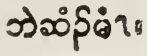

\section{ELEOCARPUS.}

At Maulmain there is seen a small tree whose hand. some summit is whitened over with a profusion of white flowers, it is a species of elœocarpus, the genus which furnishes by its tuberculed seeds, beads for the Hindoo $\mathrm{Fa}$. keers.

$$
\begin{aligned}
& \text { Elceocarpus longifolius. } \\
& \text { วามิบई: }
\end{aligned}
$$

\section{NONOCERA.}

In the southern provinces there is a species of mono: cera which bears flowers similar to the elœocarpus.

Monocera Griffithii.

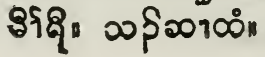




\section{ARDISIA.}

There are two or more indigenous species of ardisia that are handsome flowering shrubs. One, A. humilis, I saw in Dr. Carey's garden at Serampore, and another I have seen in European grounds on the Coast.

Ardisia humilis.

"Amherstiane

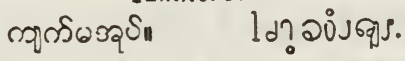

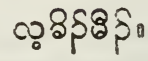

\section{ROUREA.}

The rourea abounds in the environs of Taroy, where the air is often filled with fragrance from its thick snowwhite flowers.

Rourea Sookurthoontee.

Cncstis monadelpha. cosol"

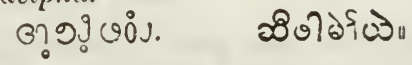

\section{MEMECYLON.}

A small blue-flowered species of memecylon bearing its flowers in compound corymbs, which contrast favourably with its shining green leaves, is interesting to the forist in this country, where blue flowers are so rare.

\section{Memecylon tinctorium.}

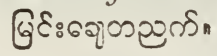

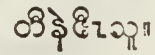

GREWIA.

Perhaps there is no tree more generally diffused throughout the Provinces than a species of grewia, whose terminal bunches of flowers may be seen on almost every knoll in the country.

\section{Grewia.}

GoSwo:

थิj

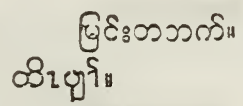

COMBRETUM.

(Taroy.)

A fragrant flowered species of combretum is common on the hills near Maulmain.-A straggling shrub, with winged fruit.

Combretum Wightiana. 
CONGEA.

In the neighborhood of Maulmain and Amherst, but rarely in the southern provinces, the forest scenery is often ornamented with the numerous large purple bracts surrounding the small inconspicuous flowers of a species of congea. In the distance it bears a strong resemblance to the dogwood tree of the Ohio valley when in flower. There are three difierent species in the Provinces, but they are all called by the same native names.

$$
\begin{aligned}
& \text { Congea azurca. } \\
& \text { " tomentosa. } \\
& \text { "scus: voluti:a. }
\end{aligned}
$$

\section{CFYLONESE NARAVELIA.}

In the southern provinces a handsome flowered climbing plant of the genus naravelia, belonging to the ranunculus tribe, is occasionly seen.

Naravelia zeylanica.

\section{VIRGIN'S BOWER.}

Griffith says there is one species of this northern genus in the Provinces "with simple fleshy leaves."

Clematis.

\section{PRICKLY PEAR,}

The hedge prickly pear is often seen in gardens, and its large yellow flowers are quite ornamental. 'The natives regard it as a species of euphorbia.

Opuntia Dillenii.

Cactus indicus.

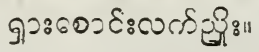

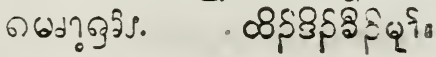

WEEPING SONNERATIA.

There is a species of sonneratia in the low wet lands near the mouths of some of the rivers, well deserving of a place in our cities. It bears a strong resemblance to the 
weeping willow and is one of the most graceful trees in the country. 'The casuarina has been removed from the coast to our compounds, and the sonneratia is quite as deserving.

Sonneratia apetala.

nosoco:

DRAGON TREE.

Two or more species of the dragon tree, resembling small areca palms are seen in Burmese compounds, bui the most common is the one with dark purple leaves.

Dracena atropurpurea.

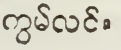

os

mర2:

\section{FRAGRANT MORINDA.}

'The most agreeably fragrant flowered shrub with which I ever met in the Karen forests, is a species of morinda, that has not yet found its way into cultivation. The fowers are small, in dense heads, like other members of the genus, azure purple externally, but white within: and have only four anthers, like a species described by Jack which he found on the Malay Islands.

Morinda.

\section{FRAGRANT I.IMOXIA.}

On all the lands near the mouths of the rivers that are occasionally overflowed by tide waters, a very handsome shrub of the orange family, with a fragrant white fower, and a small fruit like a lemon in miniature, is quite com. mon; and ought to have a place in our garden plots

\section{Limonia.}

TARIEGATED CROTON.

This shrub with handsome variegated leares is some times seen in gardens.

Codlaum chrysosticton.

Croton variegatum. 
CORAL PLANT.

Though a native of America, the coral plant, with its brilliant carmine corymbs is considerably diffused in Maulmain grounds.

Jatropha multifida.

BOJER'S EUPHOREIA.

This large scarlet-flowered species of euphorbia from Madagascar is rery common in gardens.

Euphorbia Bojerii.

POINSETTIA.

This plant has been recently introduced into the gardens in Maulmain; and its large vermillion-colored foral leaves render it, when in flower, a very ornamental plant. Puinsettia pulcherrima.

\section{RANGOON CREEPER.}

This elegant scandent shrub is seen trailing its long arms around our bowers and verandahs, buried in thick lively foliage, and gracefully flinging out its thousands of sweet-scented flowers which change their tint from white to ruse, and with the clouds at sunset, deepen into richest crimson.

\section{Quisqualis indica Qว80U์ ऊूहล}

\section{FRAGRANT PERGULARIA.}

In the gardens in Maulmain, this fragrant flowered creeper is often cultivated.

Pergularia odoratissima.

MALPIGHIA.

A handsome shrub of the genus malpighia, with leaves like the holly, and nearly related to the Barbadoes cherry, is occasionally cultivated in European gardens.

Malpighia heteranthera.

EGICERAS.

This large shrub when in bloom is covered with small white flowers, which seem to have great attractions for the 
fire-flies. In moving up the streams near the sea-board on a dark night, these trees are often seen illumined with myriads of waving brightening wings :

"Retreating, chasing, sinking, soaring,

The darkness of the copse exploring,"

And making them look in the deep gloom, like superb candelabra hung with living lamps.

$$
\begin{aligned}
& \text { Aigiceras fragrans? } \\
& \text { ฬ⿻ ถุर }
\end{aligned}
$$

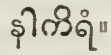

IIANDSOME CRANIA.

'The yard of a Burmese merchant in 'I'aroy, is often visited by Europeans to look at what is deemed the most curious tree in the Provinces. It is frequently amusing to listen to the observations of the spectators that may not unfrequently be seen gathered around it on a fine $\epsilon$ rening. "It is a kind of a palm," says one, "do you not see that its trunk is precisely that of a palm?"' This settles the question so long as the eyes are kept on the trunk; but another looks up and cries out, "No such thing! Look at its leaves. 'They cannot be distinguished from the leares of a plantain tree." It belongs to the natural family of the plantain, but it has the trunk of a palm, and the leaves are not arranged around the stem like those of the plantain, but in two opposite rows, so that the whole head has the form of a gigantic fan. It is the only tree of the species that I have seen on the Coast, and it was brought up by its owner from Perıang. It is well worthy of cultivation for a curiosity.

Ravenala madagascariensis.

Urania spcciosa.

\section{CASUARINA.}

The casuarinas, called beef-woods, form imposing bowers, and are the very pictures of drooping beauty. 'There is but one species indigenous to this Coast, which is the one that has been diffused over Bengal, but the species introduced into England is the one common to the Indian Archipelago, and the South Sea Islands, called in the latter place ironwood. The wood is very hard and durable, and the Tahitians in their war-days chose it for the 
manufacture of their formidable, ingeniously carved war. clubs, hence they term it the club-wood. They also fash. ioned raluable fishing hooks from its roots. The casuarina of our Provinces is found inhabiting only the loose, sandy soil of the sea-board, and never inland. In general outline it resembles the pine, but it is of a more slender figure, and more elegant in appearance. It is a remarkable tree, growing eighty feet high, and spreading out without a leaf of covering; but its numerous fine knotted branchlets, mantled with brilliant green, and hanging in drooping bunches, or floating out lightly upon the breeze like long skeins of green silk, adorn it with the most graceful drapery; rnd make it one of the most desirable trees for embellishing a T'enasserim park.

Casuarina muricata.

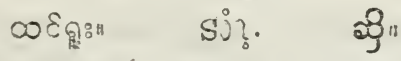

TENAESERIM BANYAN.

Eew persons are aware that we have a species of ficus in the Provinces which has the habit of drupping roots from its branches that root in the ground, and become trunks as large as the parent tree, to an extent nearly equal to the famous banyan. It escapes notice because it developess itself in the greatest perfection near the mangrove swamps, and some who see it call it a mangrove ; and it nerer grows spontaneously except on the banks of tide water streams. it is not found however, in the mangrove lands which are under water every tide, but abore that belt where heritiera trees, and their associates show themselves, on land that is inundated by the spring tides only. Specimens are seen farther toward the interior, as on the banks of the Gyaine, but on the low banks near the sea between Tavy and Mergui, the trees often form labyrinths from which I have more than once found it difficult to extricate myself. It is rather remarkable that the tree has never been introduced into our towns, where it would be quite an ornament to the sides of our public walks. In a few instances I have seen the tree planted on high ground, one at a village near the sea-coast west of 'Tavoy, where it appears to grow very well. A very nearly allied species Wight says, is " much used as 
an svenue tree" in southern India. Perliaps our tree will be referred to the same species, $\boldsymbol{F}$. Benjamina; but though much resembling it, there is still a difference that appears to be constant, and therefore specific. The Benjamina has the fruit smooth on short stems, while the 'Tenasserim tree has rough fruit and stemless. There is a difference too in the leaves, but it is only slight, and not alone sufficient to establish a species. Wight, in uniting $\boldsymbol{F}$. nitida with $F$. Benjamina, characterizes the united species thus :

"Ficus Benjamina, Leaves oval and obovate, obtuse, polished : fruit axilliary, paired, smooth."

The Tenasserim tree may be thus characterized:

Ficus $\boldsymbol{B}$ enjaminoides. Leaves oval, suddenly acuminate, smooth, polished above; fruit axilliary, paired, sessile, rough.

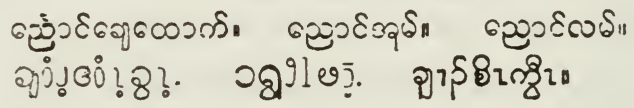

ASPEN-LEAVED PEEPUL。

The peepul is quite an ornamental tree but very scarce in these Provinces, though usually supposed to be one of the most abundant. The peepul of the residents, but not of the Burmese who recognize the distinction, is an allied but different species of ficus. It is the most sacred of trees with the Buddhists, for it was under this tree that Gaudama slept, and dreamed that his bed was the vast earth, and the Himalaya mountains his pillow, while his left arm reached to the edstern ocean, his right to the western ocean, and his feet to the great south sea. This dream he interpreted to mean that he would soon become a Buddha; and it was while seated beneath the same tree, that his dream was verified.-He vanquished the forces of Mara, ${ }^{*}$ the Indian Cupid, and became divine.

Ficus religiosa.

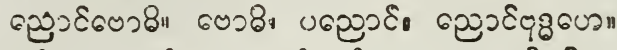

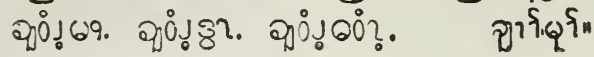

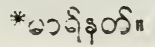




\section{HEART-LEAVED FIG,}

This is the tree which usually supplies the place of the peepul in the public places, and in the neighborhood of religious edifices. "It approaches," says Roxburgh, "neorest to $\boldsymbol{F}$. religiosa, of any species I know, yet it is easily distinguished from it by the lenves being narrower in proportion to the length, with much shorter points, and instead of the lobes forming a sinus at the base there is a small degrce of projection at the insertion of the petiole. Ind in the second place by the fruit being perfectly round and not, as in religiosa, vertically compressed."

Ficus rordifolia.

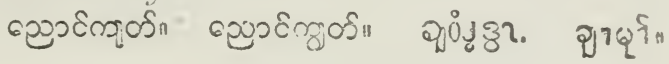

\section{CYCAS.}

There is a very ornamental species of cycas in the $\mathrm{Ka}$. ren forests resembling a low palm, but which has never yet been introduced around our European seats.

Cycas circinalis.?

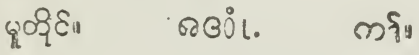

PALIYYA PALM.

The palms undoubtedly constitute the noblest tribe of plants in the whole regetable kingdom; and there is a large number of species indigenous, and cultivated in the Provinees. Excepting the areca and cocoanut, the palmyra palm, is more generally diffused than any other.

Borassus fubelliformis.

Cofis 2. 0839

\section{WILD PALMYl:A.}

'The Provinces yield an indigenous palm which the na. tives call the wild palmura. It has the fiuit of the palo nyrra, but the leaf differs from it sufficiently to constitute it another species.

Borassus.

$\cos 200 \delta 11$

0269?.

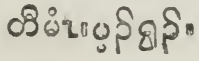




\section{TALIPAT OR LARGE FAN-PALM.}

Griffith met with trees in flower at Mergui, which he thought belonged to this species, but "not having access to a complete copy of Martius' Palms," he could not speak with certanty. For the same reason, other trees that 1 way in Taroy, must be stated as probaluly talipat palms.

C'uryizuce unbra ulifora.

$$
\text { Qul G.L. chil }
$$

BOOK FALM.

Spevimens of the palm, the leares of which are comrasily used to write on instead of paper, are not infrequent in the neighthorhood of religious edifices. I think there are :wo species in tic Provinces.

$$
\begin{aligned}
& \text { Coryzha Talicra } \\
& \text { cul clata. }
\end{aligned}
$$

DATE SARM.

1 have scen young date trees raised from the seeds of the drical dates that are imported, and there is no apparent reason why the tree might not be cultirated.

Pleconix dactylifin.

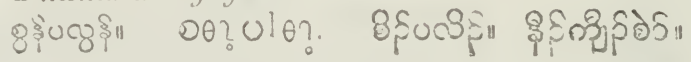

WILD D.ITE PALII.

Car). Phayre infoined me that he saw a wild date lial in wear one of the kyoungs in $A$ mherst province; but the ugh so abundant on the Hoogly, this is the only one I ever heard of in the Provinces.

Phanix sylucstris.

\section{THE MARSII-DATE PALM.}

On the low islands in the rivers, and on the shores which are inundated with the highest tides, the marshdate palm abounds, a snall tree about twenty feet high, no thicker than a walking cane; whose fruit looks preeisely like a bunch of dates, but it is not edible. 
Griffith says: "It is well worth cultivating on account of its elegance, and its being adapted for bank scenery." Phænix paluclosa.

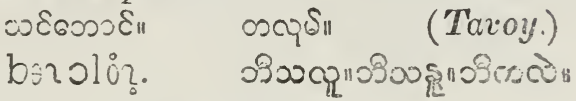

WILD PALM.

There is a large stately palm rery abundant in the Karen jungles, the leares of which the Karens use fur thatch.
Livistona.

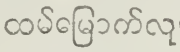
lio.s.
c8.?."

KAREN CAIBAGE PAIM.

A wild palm is found in many parts of the l'ronces, which the Karens often cut down for the uncxpanded bunches of young leares found in its summit, and which his the taste of cabbage. T'he tree does not lioverer, bcbong to the same genus as the cabbage tree of $A$ merica, but fiom the imporfect specinens of its fructification thit 1 hase seen, appears nearly related to Griflith's genin,

Iilacroclachus.

$$
\text { อุอjह"ว }
$$

WALING-CANE PALT.

The islands of the Mergui Archipelago yield a small palm, the stems of which are used for walking-stichs, litio "Penang Lawyers"; and is probably a siecies of the same genus that produces those famous canes.

Licuala.?

\section{STEMLESS LICUALA.}

This is a nearly stemless palm described by Grifith as remarkable for its dark green foliage. He met with it in the forests south of Mergui.

Licuala longipes. 
TREE RATAN.

An arboreas species of ratan common in the jungles, Griffith justly terms: " a very elegant palm."

Calamus arboresccns.

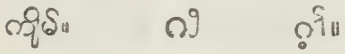

IATAN SAGO PALM.

The sago palm has not been discovered in these Provinces, but Griffith describes a palm from the Mergui Islands, which he named the ratan sago palm. "It appears," he says, "to be osculant, between calamus, sagus, and zalacca, haring the habit of the former, the inflorescence of the second, and in some measure the seed of the last genus ;" so that while it resembles a ratan, it has flowers like the sago palm.

Calamosagus lacinious.

\section{BETEL PALMS.}

The palm which produces the betelnut is extensively cultivated by the Burmese, and to a small extent by the karens. It thrives lusuriantly on our Coast, and a grove of botel palms, with their slender, cylindrical stems peering fifty or sixty feet upward, waving their green plumes, and fragrant flowers, presents a scene of sylvan beauty sarely to be excelled under our tropic sky.

"Thus winds our pih through many a bower

Of fragiant tree and giant fower-

While o'er the brake so wild and fair

Tre betel wares his crest in air ;

Yet who in Indian bowers has stood

But thought on England's ' good greenwood ;'

And bl:s sel beacath hor palmy sla $\iota$ de

The hazel and her hawthorn glate ;

And breathed a prayer, (how oft is wain !)

To gaze upon hei oaks again."

Areca Caicchir.

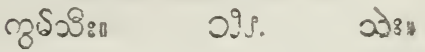




\section{SELECT ORAMENTAL HERBACEOUS PLANTS.}

The number of annuals and herbaceous flowering plants in the Provinces, though considerable, is not prow portionate to the number of trees and shrubs. For the accompanying notices, I have selected fifty of those pos. sessing most interest to the fiorist.

ELEGANT LEMPFERA.

Under every shady tree in Maulmain may be seen during the rains, a pretty little pink flower resting on broad green leaves, which Wallich appropriately named "the tlegant kœmpfera." 'Though so abundant at Maulmain, it is scarcely seen in the southern provinces.

$$
\begin{aligned}
& \text { Monolophus elcgans. } \\
& \text { Krompferä clegans. }
\end{aligned}
$$

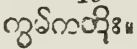

WHITE KOMPFERA.

During the dry season, a white-flowered species of kœmpfera with a yellowish limb, is often seen lifting its crocus-like flowers without a single leaf, on the most arid spots in the jungles.

$$
\begin{aligned}
& \text { Kampfora candida. } \\
& \text { uईะอใด }
\end{aligned}
$$

FRAGRANT KOEPFERA.

'This is the finest species of the genus, and is cultivated by amateurs for its beautiful sweet-scented blossomes. A nearly related species is indigenous in the Karen jungles. Kampfera rotunda.

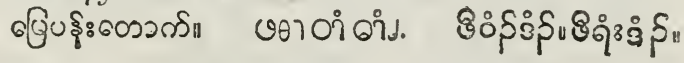

MELASTOMA.

A species of melastoma with large gaudy purple petals, and long yellow stamens, is a common weed. Its calyx opens like a lid, and bears a fruit which in taste and flavour strongly resembles the blackberry of temperate 
regions. In Bengal the same plant is cultivated as a gar:s den flower, but it does not compere with our wild plant. Melastoma malabathricum.

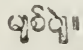
วง วักตรา.

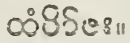

OSBECKIA.

A pretty species of osbeckia having the general appearance of the above, except that the stamens are al! of equal length, is in flower on the Maulmain hills in August.

Osbeckia.

SONERILA.

Perliaps the prettiest little annual in the neighborhood of 'Tavoy is a specics of sonerila. Its bright purple blossoms peeping up in the grass attract the attention of the most casual observer.

Soncrila.

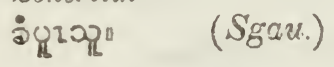

CAREY'S GLOBBA.

On shady banks in these Provinces where riolets are seen in England, the pretty orange-flowered globba is not uncornmon.

\section{Globba Carcyana.}

\section{GLorios.}

One of the most curious flowers in the country is the gloriosa. "Gloriosa," says Louden, " on account of the glorious colours of its flowers, and the elegance of their form. This is a splendid and curious genus." 'I'he flower, as large as a lily, hangs down, and the petals stamens and style all turn and grow up like a flower turned inside out. Then to complete the oddity, the leares prolong their extremitics into tendrils, and the plant walks on its toes.

Gloriosa superba.

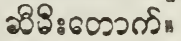




\section{TUBROSE.}

"The tuberose with her silvery light," a plant of the lily tribe, which has been introduced into India from Mexico or South America, is cultivaied rery extensively by the Burmans and in many English gardens. The fower has a delightel frugrance, and throws out its odours strongest at evening.

$$
\begin{aligned}
& \text { Policnitics tulercse. }
\end{aligned}
$$

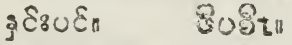

\section{GARLAND FLOWER.}

The garland flower, a species of hedychium, but regard ed by Europeans as alliy, is much cultivated by both natives and foreigners. The yellow and white varieties are both common. "This to me," says Poxburgh, "is the most charming of all the plants of this natural order that I have met with, the great length of time it contizues to throw nut a profusion of large, beautiful, fragrant blossoms, makes it particularly desirable."

$$
\begin{aligned}
& \text { Iled;chium coronarium. }
\end{aligned}
$$

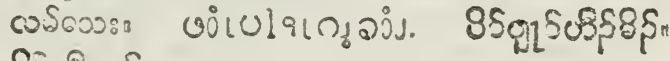

$$
\begin{aligned}
& 83 \cos 20
\end{aligned}
$$

NARROT PETALLED GAREAND FLUTER.

A very framrant species of hedychium with long narrow petals, and an epiphytic habit is often seen in Tavoy. The species is not described in any books to which I have access.

Hedychium.

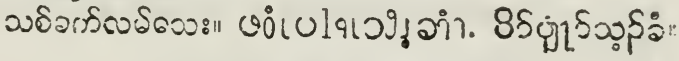

\section{WATER LILY.}

Griffith says, there are two different species of water lily in the Provinces.

\section{$N_{y_{m p h r a s}}$}

กาว

פक्ति?

- 


\section{SACRED BEAN PLANT.}

'The flower of this plant being much like a water lily, it is usually regarded as one, but the fruit is so different that botanists have placed them in different natural fanilies. Nelumbium speciosum. तु० बढ्वर. कारे"

$$
\text { ORNAMENTAL CRINUM. }
$$

We have no lilies in the country, but they are well re. presented by the crinums, which Europeans usually denominate lilies. A very large petalled species, of which there are two varieties is much cultivated in gardens, and is quite an interesting plant.

Crinum ornatum.
טद्ध६॥"
ษวาอง.

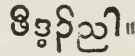

LARGE FRUITED CRINUM.

'There are two gigantic species of crinum indigenous in the low grounds near the sea coast, one of which is the large fruited crinum, and the other, which is nearly related to it, bears a large bunch of fragrant flowers and has been recently introduced into our gardens.

Crimum macrocarpon.

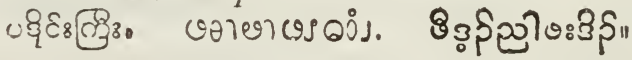

WATER CRINUU.

Many of the clear mountain streams, where they rest their waters in little crystal lakes, are covered with a fragrant and beautiful species of crinum with long narrow leares.

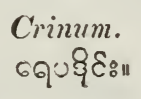

$$
\text { งชายารวำ. }
$$

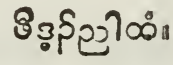

TIGER LILY.

A showy yeilow and orange flower, whose petals are spotted like a leopard's skin, and belonging to the iris 
tribe, is rery commonly cultirated by the Burmese as well as by Europeans.

Parilanthus chinensis.

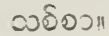

\section{EURYCLES.}

A fragrant white flowering bulb of the amaryilis tribe, and of the genus curycles, is not uncommon in native gardens.

$$
\begin{aligned}
& \text { Euryeles amboincnsis. }
\end{aligned}
$$

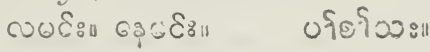

ZTPUYRANTIES.

One or two species of zeplayranthes of the amarylis tribe which I introduced fiom Dr. Carey's garden at Serampore grow rery well, and form handsome border flowers.

Zephyranties tubispatha.

GLOLL AMARANTEUS.

The globe anaranthus is often cultivated by Karens and? Burmans, as ir ell as by Europeans.

$$
\begin{aligned}
& \text { Gompterna glutiose. }
\end{aligned}
$$

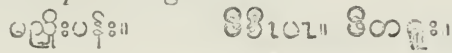

\section{COCK's Co:ns.}

This common annual all orer the world, is often scen in European gardens; and is sometimes cultirated by the natires. The Burman name signfies cock's comb, like the English.

C'closia cristata.

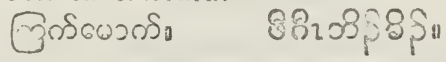

PRINCE'S FEATHER.

This is the most elegant plant, when cultivated by the Karens, that 1 ever saw of the amarantli tribe. It is not the prince's feather of English writers Amaranthus hypockondriacus, but a species of celosia which bears a long pendulous drooping panicle or plume like Roxburgh's $\boldsymbol{C}$ : 
ce'nua, but it is a different species. There are two varieties, one with bright yellow flowers, the cther with red.

Celosia.

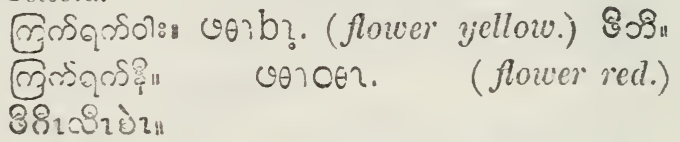

SEXSITIYE PLANT.

Wrere "garilen flowers grow wild," near deserted habitations the pink globular heads of the sensitire plant may he often seen peeping through the grass. It is cultirated by the Burmese, and is quite naturalized.

$$
\begin{aligned}
& \text { Himosa sensitiva. }
\end{aligned}
$$

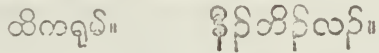

GIIRISTMAS D.MYY.

$\mathbf{A}$ species of aster, or christmas daisy, is seen occasionally in European garderis.

ITICRTEW.

Feverfew a gaudy flowe eả annual, nsually denominated a chrysanthemum, but which the botanists hase remored to another genus, is often seen in gardens in Mialmain.

Pyictlowm indicum.

\section{roricorsis.}

The bright yellow flowcred coreopsis, of the same tribe as the above, which derires its name from the resemblance of its seeds to an insect, is not uncommon in gardens.

Coreopsis.

\section{PERHTECLE.}

Periwincles, both the red and white rarieties, are frequently cultivated by natires as well as Europeans.

I'inca rosca.

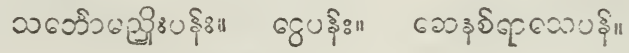

PLUHBAGo.

Three dificrent species of plumbago, the red, the white, and the blue flowered, are common in gardens; and the 
first two are cultivated by the Burmese for the resicatory power of their roots.

Plunibago rosea (flower red.)

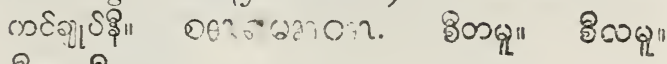

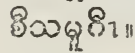

plumbago - yzanicu (jocerr white)

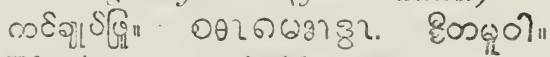

Plumbago capensis (flower blue.)

rOUR O'CLOCK.

The red, white, and yellow rarieties of this pretty annual are all cultivated by the Burmese as well as by Europeans, who often call it the jalap plant. The true jalap, is however quite a different plant, a species of ipomen.

Mirctbilis Jalape.
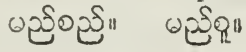

COSTUS.

An indigenous species of the spirical costus is rery ahundant, but I do not find it described in the books to which I can refer.

Costus argyrophylius?

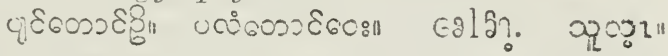

BALSAM.

The common balsam, or touch-me-not, Nout me tangcre is very common both wild and cultirated.

Impations Balsamina.

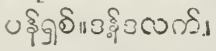

องาอวง 695.

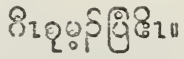

NELLGERRY GRASS.

This is a species of lobelia, which is unknown on the Nellgherries, its name notwithstanding, and probably came from Java. Wight, writing on the lobelias says: "There is a small cespitose species much cultirated in pots, by arnateurs, under the strange name of Neilgherry grass. I susject the Lobclia succulcnta of Blume, a Java plant." 


\section{GENDARCSSA.}

An indigenous species of gendarussa is often planted for borders around our gardens.

Gendarussa vulgaris.

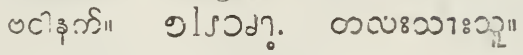

BRYOPIILITM.

This curious flowered plant wih a leaf like the houseleek was introduced into In a $L$ ly Clire, from the Moluccas, and has been so ne $\quad \cdots$ his Coast, that

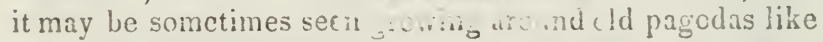
a wild plant.

Jiryophylium calycinum.

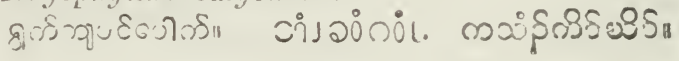

IXDIAN SITT.

Both the red and yellow varietics of indiais sliot are often seen in gardens, an 1 the first is much cultirated by the Burmese for the seeds which they use for sacred becds.

Canna indica.

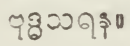
vojulalerl.
350 ร.o

HOLLY LEAVE ACANTHUS.

Erery muddy bank is relieved by crowds of a handsome blue flowered plant with leares like a holly, and hence called the holly-leaved acanthis. The Bumans say its roots are a cure for the bite of poiconous snales.

Acanthus illicifoliz?s.

ว:p:II

rovtrinas.

The margins of many wild junģle streams are pimpled with a small species of the pontedera.

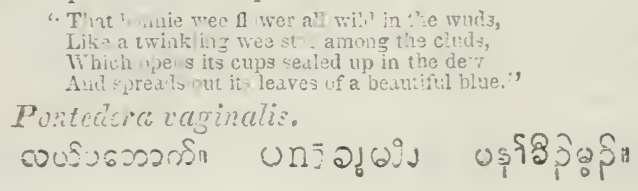


A much larger species is found in the neighborhood of $R$ angoon, and may exist in these Provinces.

Pontedera dilatata.

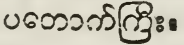

LUDWIGIA

In stagnate water, a species of ludwigia which bears 2 pretty flower, is quite common.

Ludwigia parviflora.

BEGONIA.

A pretty little annual, a species of begonia is common in the neighborhood of both Tavoy and IIaulmain.

Begonia.

XYRIS.

A species of xyris with conspicuous yellow flowers on imbricated scaly heads, is often seen in the paddy fields. $\boldsymbol{X} y$ ris indica.

\section{SPIDER-WORTS.}

Several species of spider-worts are abundant One, a creeping species of commelyna may be often seen trailing up the sides of fences. Another with blue flowers like the former but with a different habit, is sprinkled among the grasses at almost every door. It belongs to the genus aneilema. 'There are also one or two other species common, but I do not find them described.

Commelyna caspitosa.

Ancilema herb́accum.

FLAGELLARIA.

A species of flagellaria is often seen, and is easily recog uized by the tendril it puts forth at the end of its leaves.

Flagellaria indica.

\section{LORANTIYUS.}

Many of the trees are covered with different species of the parasitical genus loranthus, so abundant in most tropical climates; and the numerous small red flowers of one or two species in our forests are quite ornamental.

Loranthws. 


\section{SUNDEW,}

There is frequently seen a delicate flower, so small that st is passed unnoticed by most observers, which is a species of drosera, that curious genus of the sundew tribe, which produces Venus' fly-trap. There are two different species at Tavoy.

\section{Drosera indica. \\ " peltata.}

\section{THE FRAGRANT AREM.}

This is a most singular plant. It has a stem one or two feet high and six inches in diameter resembling a low palm, while its leaves are gigantic cabbage leaves three or four feet long by two or three wide. The flowers are said to be fragrant. 'The natives cultivate it not for food, like the other species of arum, but, as they say, for medicine.

\section{Arum odorum.}

8ริธงววดุด

RIEBON-LEAVED PINE APPLE.

This is a very ornamental variety of the pine apple that has been introduced from Malacca.

Ananas striatifolia.

\section{PARASITICAL INCARVILLIA.}

This is an epiphytical plant with flowers resembling the foxglore; and when in bloom it is a great ornament to the trees on which it grows, putting forth large, pendulous brilliant blossoms. It is common at Tavoy, but was not known in Maulmain until I introduced it a few years ago.

Aschynanthus parasiticus.

Incarvillia.

CINNABAR COLOURED ERANTHEMUM.

On the sides of some of the limestone cliffs in Amherst Province this bright orange-scarlet flower is often seen; and it would be quite an addition to our gardens, in 
which it has not yet found a place, although it is represented in Wallich's rare Indian plants.

Eranthemum cinnabarinum.

GOAT-FOOTED IPOMEA,

On the sands of the sea shore, this large rerl-purple fowered species of ipomæa is abundant.

Ipomea Pes capro.

Convolvulus

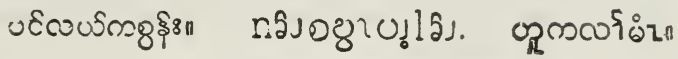

TIGER-FOOTED IPOM EA.

This species of ipomæa with large palmated leaves is not uncommon.

Ipomaa Pes tigridis.

ARROW-HEADED IPOMAA.

There is an elegant little twining species of Ipomæa with arrow-headed shaped leaves. The corolla is cream. coloured with a purple eye. It is in bloom in the hedges of Maulmain at tha close of the rains.

Ipomaa.

BONNET IPOMAA.

In October, as soon as the rains close, a pretty little twining species of ipomæa is seen blushing through every hedge and bush. It is peculiar for its concave bounet shaped involucre, in the midst of which half a dozen iny blossoms hide their rosy lips.

Ipomaa pileata.

MOON FIOWER.

A large fiowered species of ipomea whose snowy blosscms open at sunset and shut at daylight is sometimes seen carried over arbours and pandols on this coast. It is

"the white moon-flower, such as shows

On Serendib's high crags to those

Who near the isle at evening sail,

Scenting her clove trees in the gale."

Calonyction Roxburghii.

Ipomaa grandiflora. 
Another species with the same English name is occasionally seen in European gardens.

Calonyction speciosum.

JASMINE ROUGE.

This beautiful little creeper which the French and Burmese call red jasmine, the English China creeper, and the botanists quanoclit or dwarf bean, is quite naturalized throughout the Provinces. I have adopted the French name as being both more descriptive and euphonious than either of the others.

Quamoclit pennatum.

Ipomaa quamoclit.

60560089:日

HAIFY LETSOMIA.

A large red flowered creeper of the convolvulus tribe, and genus letsomia is seen during the rainy season on almost every hedge.

Letsomia sctosa.

\& $0\left\{\$_{11}\right.$

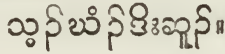

THUNBERIA.

A large creeper with azure flowers belonging to the genus thunbergia is a conspicuous plant in the forests. 1 do not find the species described in any of the books to which I can refer.

Thunbergia.

HOLY BASIL.

The basil tuft so often seen about the temples of Hindus,

"that waves

Its fragrant blossoms o'er their.graves."

has been so generally introduced that it is not less common in the neighborhood of Karen houses.

Ocimum sanctum.

u $88 \$ 810$

rocter.

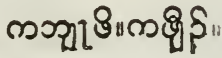




\section{AIR PLANTS.}

The Tenasserim Provinces abound in air plants, or orchids, most of which grow on trees and are epiphytes, but not parasites as they are often, by a misnomer, denominated. More than fifty different species have been? described, and there are probably as many more unknown to science. The flowers of some of the species are great favorites with the natives, and are sought after to adorn the hair. 'The Burman books say that the trees around King Wathandria's hermitage were covered with orchids, and that after being plucked they would retain their fragrance seven days.

Nearly every species is worth more in England than its freight overland; and they are often exported. It is usu. ally supposed that the plants require air on their passage, consequently the boxes in which they are packed are often perforated, or they are sent in baskets. But this is an errour. The closer they are confined, the better will be their condition on reaching the place of destination.

A gentleman in England to whom I sent a box of orchids a few years ago, remarked: "The plants were in as good condition, as any I ever had from the east, in fact had it been the dry season when you packed them, I doubt not all would have come in full health, and you cannot possibly do better in future than pack them in a precisely similar manner. Their excellent condition convinces me that a great many of my losses amongst those $I$ have had from the Botanical Garden at Calcutta, have been caused by the fact of their being packed in bamboo baskets instead of close boxes, - a close bor seems essential."

There is ro good reason why this noble, graceful tribe of plants should be so much excluded from our compounds, and left to fling their beauty upon their native wilderness of flowers, and "waste their sweetness on the desert air." If generally introduced, they might be a rick acrquisition to our tropical parterres. 


\section{CHARMING DENDROBIUM.}

The genus dendrobium furnishes fifteen or more known species of air plants on this Coast. The one considered most interesting, botanists have named the "charming dendrobium," the flowers of which are white, with a yellow lip, three or four inches in diameter, and exquisitely fragrant. It is a choice flower with the Burmese, and grows naturally and luxuriantly in the environs of Maulmain. Roxburgh mentions April and May as the time of flowering, but I tave observed the plant blossoming in March, and the flowers are brought into town throughout the whole rains down to the close of October. Indeed it may be seen whitening under the emerald foliage of tlie groves nearly six montlys of the year. The Burmese call it the "silver flower."
Dendrobium formosum.

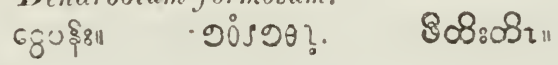

PERPLE DENDROBITI.

A species of dendrobium with small purple flowers, the lip tinged with orange, is seell garnishing the mango trees in the nerghorhood of Maulmain. The flowers are peculiar, being in long racemes all on one side of the stalk. Lindley was not aware of its existence in these Proviuces, and only quotes it as found in the straits of Malacca and the neighbring islands. He also says, that it flowers in Jume and Jaly; but on this Coast, Mareh and $A_{p}$ pril are the months in which it is in full bloom.
J.ndrobium secundem.
0,0 -
งวางว่ง
8๐ిగి:"

YELLOW DENUROBITM.

'I'wo preity yellow flowered species of dendrobium are more rare tlien the purple, but they are not uncommon is the Karen jungles.
Dendrobium Picrardi.
Dendrobium aggregatum.

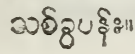




\section{WHITE DENDROBICM.}

A species with a small snowy flower is very abundant, but has less to recommend it then either of the preceding. Dendrobium cretaccum.

\section{TAPER-LEAVED DENDROBIUM.}

An orchid with a filiform tapering leaf is frequent in the suburbs of Maulmain, and though I lave nerer met with it in blossom, an English botanist says it is the taper-lear. ed dendrobium, which Lindley knew only as a New Holland plant.

Dendrobium teretifolium.

\section{SPOTTED SACCOLABICM.}

One of the noblest orchids in the Prorinces belongs to the saccolabium, or bag-lipped genus; the lip forming a bag, or spur. The flowers are numerous, white, spotted with rose-violet, and stand on little peaicils all around the stalk so as to form an elegant plume sometimes a foot long, which give the trees on which they grow a most princely appearance. 'T'hey are profusely multiplied in the neiglboshood of Maumain, and are highly ralued in England.

Saccolabium rctusum.

" guttatum.

Aerides guttatum.

\section{RED SACCOLABIUM.}

Another species of the same genus with rosy flowers, is also very hardsome and quite abundant.

Aceoclades ampullacea.

Saccolabium rubrum.

Aerides ampullaceum.

Lindley says it can scarcely be distinguished from $\mathbb{S}$. ampullaceum of Wallich's catalogue:

FRAGRANT AERIDES.

The genus aerides furnishes one of the most fragrant of orchids, but it is not very abundant in our forests.

Acrides odoratum. 


\section{FRAGRANT BOLBOPHYLLUM.}

Perhaps the most highly valued of the orchid order among the Burmese and Karens, is the sweet-scented bolbophyllum, which Karen youths wear in the lobes of the ear, and maidens in their hair. It abounds in almost every part of the jungles, throwing down delicate straw coloured racemes over the rough gray bark of old lagerstrœmias-emblems of childhood in the arms of age.

Bolbophyllum.

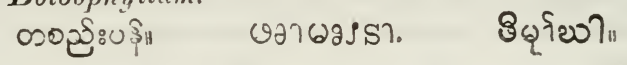

\section{CAREY-BOLEOPHYLLUM,}

This is a very common orchid in the vicinity of Maul. main, easily recognized by a long leaf at the apex of a false bulb, aud by its small purplish Hower.

Bulbopleyllan Carcyanum.

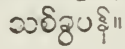

ERIA.

A specis of eria is also one of the most abundant of our epiphytes, but the flowers are small, and have little to res commend them.

\section{Eria obesa.}

\section{PHOLIDUTA.}

In the suburbs of Maulmain, a white flowered species of pholidota is not rare.

$$
\begin{aligned}
& \text { Pholidota articulata. } \\
& \text { ขิฮీจิ }
\end{aligned}
$$

TRIAS.

Many of the mango trees have a species of trias grow: ing on them, the smallest plant of the orchid tribe that I hate seen in the Provinces.

\section{Trias oblonga.}

\section{HA BENARIA.}

There is an elegant species of habenaria in the Tavoy forests; and several other species of the same genus art scattered over the Provinces.

Habenariu acuifera: 


\section{PERISTYLCS.}

An elegant terrestrial orchid with snowy blossoms is occasionally seen, which belongs to the genus peristylus. Peristylus.

\section{GEODORUM.}

Two other terrestrial species are members of the genus geodorum.

$$
\begin{gathered}
\text { Geodorum candidum. } \\
\text { " pallidum. }
\end{gathered}
$$

VANILLA.

Dr. Falconer discorered, while on his visit to the Provinces in 1849, a new species of vanilla, but its specific name and description have not yet transpired.

$$
\text { Vanilla. }
$$

\section{FERNS.}

The ferns are among the most curious objects in the vegetable kingdom, and numerous species are indigenous in these Provinces.

\section{TREE FERN.}

A tree fern is very rare but is occasionally seen in the southern Provinces, resembling a small palm. Griffith found the same species in Assam.

The natives have but one name for both the cycas and tree fern.

Polypodium gigantcum.

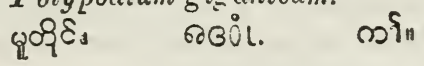

\section{CLIMBING FERN.}

One of the most elegant climbers on the Coast is a terrestrial species of fern, easily recognized by its habit of running over other plants, and by the fringed margin of its leafiets, from which it is sometimes called "fringed fern." An allied species is found in the United States.

Lygodium scandens.

$$
\begin{aligned}
& \text { Ophiglossum }
\end{aligned}
$$

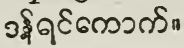

$$
\begin{aligned}
& \text { วิว จวิ). }
\end{aligned}
$$

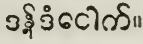$$
\text { (Tavoy.) }
$$ 


\section{OAK-LEAVED POLYPOD.}

In some parts of the forests, the trunks of almost every tenth tree have a great abundance of a large species of polypod growing upon them. The barren fronds are cordate, and stemless; but the fertile ones stand on long slightly winged stems, and are gashed like the leaves of an English oak.

$$
\begin{aligned}
& \text { Polypodium qucrcifolium. } \\
& \text { 6aว mifo Sog il } \\
& \text { งม จริาตฐง. } \\
& \text { 똟ำ }
\end{aligned}
$$

PITTED POLYPOD.

T'his fern is often found in company with the preceding species; and may be easily recognized by its creeping liabit, and by the margins of the upper parts of its fronds being rolled together when in fructification.

Polypodiun portusum.

\section{REED FERN.}

There is a large terrestial fern with hollow stems like a reed, which are often used by the natives instead of quills for pens.

$$
\begin{aligned}
& \text { Polypodium. }
\end{aligned}
$$

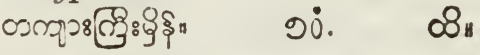

\section{STIPE-CLASPING BRAKE.}

A large brake is common at Taroy with pinnate fronds, whose leaflets have two lobes at the base which clasp their stipe.

$$
\begin{aligned}
& \text { Pteris amplexicaulis. } \\
& \text { ๓กวว๋ } \\
& \text { ราพญ்" }
\end{aligned}
$$

GRASS FERN.

The trunks of our forest trees are often clothed with the green drapery of the grass fern, which grows upon them precisely like bunches of long grass. It belongs to the same genus as the common brake.

\section{Pteris graminifolia.}




\section{DAVALLIA.}

An elegant fern of the genus davallia characterised by the fructifications being " in roundish separate spots, near the margin," is very plentiful in the neighborhood of Maulmain.

Davallia.

NULE FERN.

Near the sea shore a species of mule fern with cordate fronds is sometimes seen.

Hemionitis cordifolia.

SCANDENT LOMARIA.

The low lands near the mouths of our rivers and nullahs, are often fantastically dressed with a species of lomaria which creeps up to the tops of the tallest trees.

Lomiciria scandens.

TAPEWORM FERN。

The tapeworm fern, so called from the resemblance of the line of sori to a tape worm, is not infrequent.

Tanis blechnoides?

\section{MAIDENHAIR.}

A small handsome fern is seen in the crevices of old ruins and walls every where, of the same genus and nearly resembling the English maidenhair-" the prettiest of all ferns."

\section{Adiantum.}

CLUB MOSS.

The green woods of our suuthern provinces are often carpeted with the club moss, or ground pine, of which we have one or two handsome species.

Lycopodium.

SALVINIA.

A curious little floating plant, related to the ferns, of the genus salvinia is often seen on the surface of old tanks and stagnate waters.

Salvinia cucullata. 


\section{TABLE FRUITS.}

There is a great variety of fruits indigenous and exotic in this part of the British Territories, and to a native, who while a child eats a raw sweet potatoe with as much zest as a European would an apple, they are no doubt considered unsurpassable. The ancient Celts eat acorns, and the modern Californians still use acorn bread, and the Burmese and Karens eat fruits which are but little superior to an acorn. Some however, are thought to be delicious and are held in high repute; but in general they are much inferior to the fruits of temperate climates.

MANGOSTEEN.

"Malaya's nectared mangosteen" is truly a delicious fruit, and by many esteemed as "the most palatable of known fruits," but though very delicate it is not to be compared to an American peach. It is cultivated to a considerable extent in Mergui, but is rarely seen in the northern Provinces.

Garcinia mangostana.

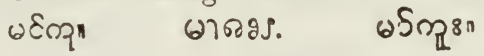

DORIAN.

The dorian holds an important place among the fruits of this country being regarded by the voluptuous natives as second to none. It is probably the most fæted fruit in existence. Wight speaks of "the dorian so celebrated on account of its fine flavored but excessively fotid fruit ;" and adds: "It is said by Rumphius to be of a very heating quality, liable to excite inflamatory derangements of the system."

Durio zibcthinus.

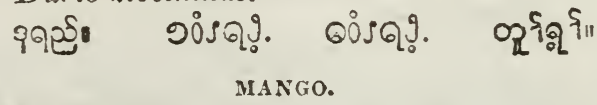

The Mango deserves the first place among the indigen. ous fruits, being, as Dr. Lindley truly says: "To the inha. bitants of India what the peach is to Europeans; the 
most grateful of all fruits. Its flesh is filled with a rich luscious juice; but the inferior kinds have also so much turpentine flavour as to be uneatable." Unfurtunately, our Mangoes are notoriously inferior; and to say no. thing of the turpentine flavor that some of them occasionally have, half, if not three fourths of all that are sold in the bazar, are worm eaten, though that is not at all apparent when they are bought.

There are two different species, both of which the na. tives say grow wild, and several varieties are cultivated in the Provinces. The finest is a variety from Siam, which produces a large fruit with a very thin stone.

$$
\begin{aligned}
& \text { Mangifera indica. } \\
& \text { sylvatica. }
\end{aligned}
$$

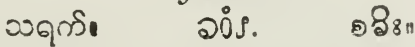

\section{HORSE NLANGO.}

This is a large mango multiplied at Mergui, and is rquite a farorite with the natives. It has an odour resembling the dorian, and like that has been introduced from the Straits.

$$
\begin{aligned}
& \text { Mangifera fatida. } \\
& \text { cogos, } 0621 .
\end{aligned}
$$$$
\text { พุ:1 }
$$

$$
\text { OPFOSYTE-LEAVED IIA:SO. }
$$

This indigenous tree produces a fruit much hike a plum. There are two varieties, - on: bearing an intensely sour fruit, and the other, one as insipidly sweet.

$$
\begin{aligned}
& \text { Cambessedea oppositifolia. } \\
& \text { Mangifercs } \\
& \text { เอิุี" } \\
& \text { २?. } \\
& \text { อ ะงิ" }
\end{aligned}
$$

LICIII.

The lichi, originally from China, is a farorite fruit in Bengal, but did not succeed on this ${ }_{2}$ Coast until recently. The trees bore their first fruit last year.

Nephelium Lichi. 
PAWPAW.

The first fruit that I saw on the table in Burmah, was an American pawpaw, not the pawpaw of the Mississippi valley, Porcelia triloba; but the pawpaw of South America and the West Indies. Europeans call it papaya, from the Portuguese papayo; and by the Portuguese it was probably introduced into India. The fruit resembles a melon in appearance, and often tastes no better than a good English turnip.

Carica Papayan.
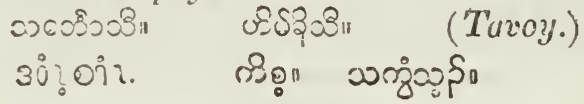

GCIVA.

The guara, another American tree is planted perhaps more extensirely than any other fruit tree in the country. Loudon has the most correct notion of the fruit that $I$ have seen. He says: "Most of the species are cultirated in the tropics for their fruit, which also ripens freely in this country, but is of little merit."

The white guava is the species most usually cultivated : but the :ed is not uncommon.

$$
\begin{aligned}
& \text { Psidium pyrifcrum (wlite.) } \\
& \text { "pomifcrum ( } r \text { c cl.) }
\end{aligned}
$$

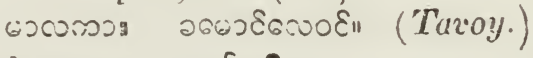

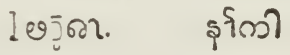

FINE APPLE.

Another of the most abundant fruits in the Provinces is the pine apple, also an American production. With the plant, the native American name appears to have been introduced into Burmah, for nanas is said to be the name it had among the Peruvians where it was originally found, and the Burman name is nanat; which the Sgats have abbreviated to nay.

Ananas sativus.

Bromelia Ananas.
कว की।
ถาดุ? 
PLANTAIN.

The plantain or banana, though a far less palatable fruit, holds the same place in this country that the apple does in England, and the United States. It is used as a veghetable as well as an article for the dessert, the great proportion being eaten with rice and meat in the place of potatces.

There is perhaps no plant of which so many preposterous things have been carelessly written in books of trarels, and then copied into works of graver character, than this. Among other things equally reritable, it is said, * "Three dozen plantains are sufficient to serve one man for a week instead of bread, and will support him much better." A Karen by me says he often eats ten at a time, and a hundred would not be sufficient fur a man one day if he had nothing else, unless they were very large.

like t?e mango, the tree is indigenous, but the wild fruit is too full of seeds to be eatable. The plantain and banana, which were formerly regarded as distinct, are now considered by botanists as one species, but it cmbraces tnany varieties; I hare the Burman names of twonty-fivc before me. "The numerous varieties," writes Voigt "we have in vain tried to put in some order. The attempt made for this purpose, in Schultens, appears to us to have only increased the confusion." The Hanila hemp, from which a fabric of the finest texture is prepared, is made from the leares of a species of plantain tree, $M$. textilis. Another distinct species of this genus grows wild in our jungles, and is rather an ornamental plant, which is all that it has to recommend it. Unlike the common plantain it neter throws up shoots from its roots.

The name of the plantain in Pali is mauze, which is its Arabic name, mauz, with a final rowel added, to pronounce the last consonant, no words in Pali, ending in any conconant excepting $n$. Now if its Arabic name be so widely diffused, it seems quite certain that had the plant been known to the Hebrews, the Hebrew being cognate with Arabic, it would have had a similar name. This fact is a sufficient refutation of the conjectural interpretations of

- See Loudon's Fncyclepedia of Plants, under M. paradisiaca. 
certain passages of Scripture that we meet with from time to time. Thus: "Loudolf's conjecture that dudaim (mandrakes) were the fruit of Musa paradisiaca, (plantain-tree,)" which has been recently revived in a modern work, cannot stand, on account of its name. For the same reason, the conjecture that the grapes which the spies brought from Canaan, were plantains, cannot be sustained. The plantain seems a favorite plant to build fancies upon. Gesenius in defining tecnah, the fig tree, refers to Gen. 3:7, "Where," he says, "the Ficus inclica or Musa paradisiaca, plantain tree, Engl. with very large leaves seems to be meant." This is perfectly conjectural and is wholly unsustained by the usage of the word, as well as that it bears no resemblance to its Arabic name.

Musa paradisiaca.

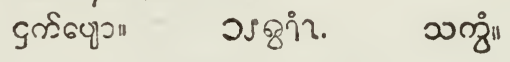

OLEASTER PLUM.

This sour red plum makes very good tarts and jellies, and abounds in some parts of the jungle.

Elaagnus conferta.

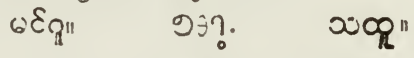

MALAY APPLE.

This tree thrives luxuriantly at Mergui, and bears some resemblance in taste to a juicy apple, but it is a very in. different fruit.

Eugenia malaccensis.

Jambosa malacconsis.

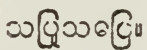

ROSE APPLE.

The rose apple described, as " tasting like the smell of a rose," is cultivated to a small extent in European gardens.

Eugen:a Jambos.

Jambosa vulgaris.

JAMEO FRUIT.

A small black plum is often seen in bazar which is produced by a species of eugenia. According to Burman 
geography there is a eugenia tree on the great island or continent which we inhabit, that is twelve hundred miles high, one lundred and eighty six in circumferance, with five principal branches each sis hundred miles long. From this tree, the island derives its name sambu-deba, Eugenia Island.*
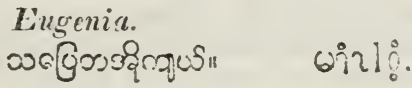

2002009 ริ"

IERTTIERA FRUIT.

One of the best and most plentiful of the jungle fruits is the leritiera. It grows in bunches resembling large, grapes, is agreeably sub-acid, and when ripe, of a yellowish hue. 'The tree is small, and when arrayed with these long golden bunches it is rery beautiful. It would be quite an acquisition to our gardens both for ornament and utility.

$$
\begin{aligned}
& \text { Ileriticra attenuata. }
\end{aligned}
$$

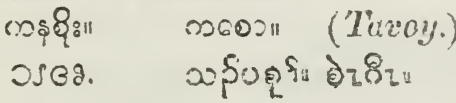

$$
\begin{aligned}
& \text { CUSTARD APRIE. }
\end{aligned}
$$

The custard apple, an American fruit, is cultirated by the Burmans in these Provinces occasionally, and quite extensively in Burmah Proper. The pulp is very agrecable, and has much the appearance of custard.

$$
\begin{aligned}
& \text { Anona squamosa. } \\
& \text { כुa)" }
\end{aligned}
$$

$$
\text { Sotr sor. }
$$

This fruit, resembling the custard apple, is sometime cultivated by Europeans.

$$
\text { Anona muricata. }
$$

* From ogfln-a eugenia tree (Pali.) " 8ुgी-an island. 


\section{BULLOCK'S HEART.}

Of the same genus as the custard apple is the bullock's heart, which I have occasionally found in native gardens. Anona reticulata.

UVARIA FRUIT.

'This fruit has the taste and appearance of the North America pawpaw, and they are members of the same natural family. It is the produce of a scandent shrub abounding in the jungles.

$$
\begin{aligned}
& \text { Uvaria grandiftora! } \\
& \text { ogos. Jòsueroin. } \\
& \text { ORANGE. }
\end{aligned}
$$

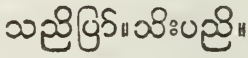

Oranges are quite abundant, but for the want of proper attention they are much inferior to the West India oranges, and to those cultivated in the South of Europe. The trees are often exceedingly prolific. A seedling that I planted, produced in the ninth year more than two thousind oranges.

$$
\begin{aligned}
& \text { Cirrus aurantium. }
\end{aligned}
$$

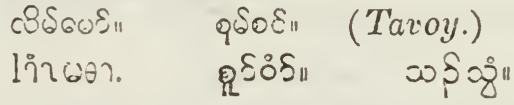

SWEET LIMES.

A considerable proportion of the fruit sold for oranges are sweet limes. Dr. Pickering of the American Exploring Expedition, remarks: "I did not meet with the true orange, either in Hindostan or the East Indies." The tree may be often distinguished by its leaf which is usually slightly winged, and smaller than the orange.

Citrus limetta.

SHADDOCK.

The shaddock or pumplemuss may be often procured in market, but the fruit is decidedly inferior to the Bengal pumplemuss.

Citrus decumana.

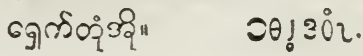

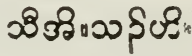


THREE-LEAVED TRIPHASIA.

'The three-leaved triphasia which bears a small berry like an orange in minature, often found in Chinese preserres, is raised in European gardens.

\section{Triphasia trifoliata.}

BENGAL QUINCE.

The Bengal quince is grown by the Burmese to a small extent.

Figle marmelos.

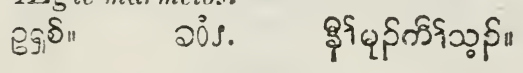

WOOD APPLE.

Captain Phayre told me that he had seen the rood ap. ple in cultivation by the Burmese in Amherst Province, but I have never observed it.

Feronia clephantum.

乌\$:

CITRON.

The citron is cultivated, and I have met with citron trees in the jungles apparently indigenous. The fruit however, is much inferior to the Bengal citron.

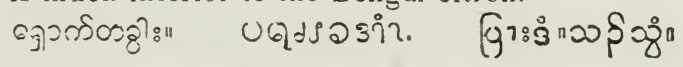

SMALL IIME.

The small acid lime is seen almost every where in abundance.

$$
\begin{aligned}
& \text { Citrus bergamia. } \\
& \text { " acida. }
\end{aligned}
$$

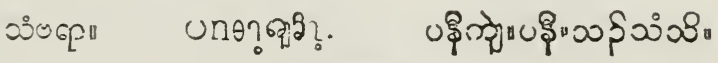

LARGE LIME.

Large varieties of the acid lime are diffused all over the Prorinces; and Europeans usually call them citrons; but the trees are easily distinguished by their leaves, as the leaf of the citron is simple, while that of the large lime is winged.

Citrus bergamia.
छुर्ती:
UอุगS.

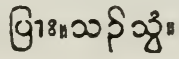




\section{DOUBLE-LEAVED CITRON.}

There is a species of citrus at Tavoy with a leaf that looks like two leaves joined together, the wings on the petiole being as broad, on even broader, than the leaf itself. The fruit is small and there are two varieties, one with a smooth, and another with a rough skin. I do not find it noticed in any of our Indian Floras, but Dr. Pickering met with a similar tree on the Samoan Isladns, a member of the Philippine Flora.

Citrus torosa?

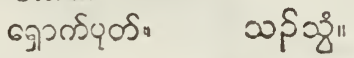

POMLGRANATE.

The pomegranate is cultivated to a very small extent in gardens by both Burmese and Europeans.

Punica granatum.

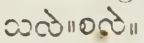
วเรา.
20ते।

WILD RAMBOUTAN.

One of our indigenous trees bears a fruit whose subacid aril is very agreeable to the palate, and much resem. bles that of the ramboutan so famous at Malacca Malays to whon I have shown the fruit, say it is the wild ratiboutan, and the tree certainly belongs to the same genus; but never having met with it in flower, I cannos determine the species.

Nephelium.

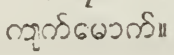

291000 ำ. 693.

os

SCHLEICHEHA.

The fruit of this tree resembles the wild ramboutan in every thing except that it is covered with prickles half an inch long. It is rarely seen in market but would be a valuable addition to the dessert. 'The tree grows among the hills of T'aroy.

Schleichera.

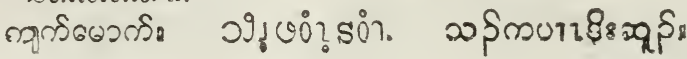


OTAHEITE GOOSEBERRY.

This tree, which is larger than the jujube, is planted by the Burmese all over the Provinces, who value its fruit highly. It bears some resemblance to a gooseberry both in appearance and taste; and I have heard it called "the Otaheite gooseberry." The tree here is diøcious.

Cicce disticha.

Phyllanthus longifolius.

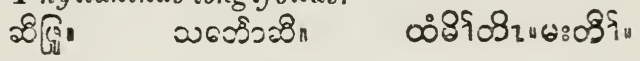

CARAMBOLA.

The carambola tree bears a sour fruit which makes a good tart, and there is a variety which bears a sweet fruit. The tree, though originally, it is said, from the Noluccas, flourishes well on this Coast, and is quite naturalized.

Averrhoa Carambola.

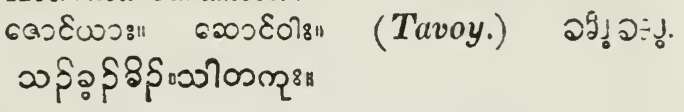

BILIMBI.

The bilimbitree, another species of the same genus, has been introduced into a few of our gardens, where it bears profusely, and its fruit is used like that of the carambola. Averrhoa Bilimbi.

BRAZIL GOOSEBERRY.

A species of physalis which bears a berry, sometimes called the "Brazil gooseberry," is occasionally seen in gardens, and the fruit in tarts has much the taste of the gooseberry.

Physalis peruviana.

\section{SAPODILL I PLCM.}

In a few European gardens may be found the tree which produces the sapodilla plum; whose "fruit, in appearance like an old decayed potatoe, is yet the most luscious in the West Indies."

Achras Sapota. 
CHOCOLATE-NLT TREE.

The chocolate-nut tree is seen in Tavoy gardens, and it brings its fruit to perfection.

Theobroma Ćacao.

BENGAL CLRRANTS.

In some of the Luropean gardens a species of carissa is cultirated for its berries, which taste when stewed like currants.

Carissa Carandas.

G.RANDII L.A.

This luxuriant exotic from the Jamaica passion flowers, flourishes well on the Const, and is very prolific. The smooth oblong fruit grows nearly as large as a cucumber, and contains a succulent pulp, which makes a cooling delicious dish, and when prepared in tarts, can scarcely be distinguished from green apple. The Rev. Mr. Bennett of 'Taroy, has recently introduced it among the Karens, by whom it is highly esteemed, and mucls sought for. It will no doubt soon be generally diffused through the Provinces, as it possesses all the attractive qualities of fine fruit, handsome fragrant blossoms, and when trailed over an arbor, a rich pleasing shade.

Passifiora quadrangularis.

30ว0008 81

IUบUERก์.

There is a species of mulberry from China sparcely diffused throughout the Provinces, which produces a rery agreeable black berry in great quantities and is a valuable fruit.

$$
\begin{aligned}
& \text { Morus atropurpurea. } \\
& \text { ५:0า1 } 9033 .
\end{aligned}
$$

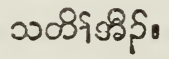

STRAIVRERIIY.

I hare raised rery fine strawberries in my garden at Taroy, but the plants require considerable care.

Fragaria. 


\section{WILD RASPBERRY.}

Griffith says there is a species of rubus in the Provin. ces, and Wallich found one on the Irrawaddy ; but whether either produces an edible fruit or not, I am unable to say. 'The existence of an indigenous species, though worthless itself, is however, interesting; as it indicates that the true raspberry might be propagated with success. Rubus Goureephul.

\section{TOSELLE.}

The roselle plant, the red sorrel of the Wiest Indies, is very widely diffused and its red sour calyx makes a fine farored jelly, and preserve, which is a good substitute for cranberries.

$$
\begin{aligned}
& \text { Ifibiscus Sabdariff. }
\end{aligned}
$$

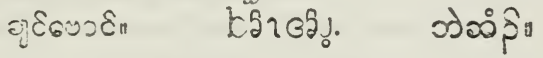

WATER MELON.

Both Burmese and Karens raise water melons, but they are neither so large nor so sweet as those of America.

Citrullus Cucurbita.

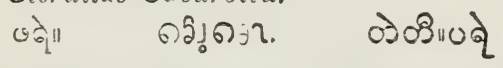

MCSK UELON,

A very indifferent musk melon is cultivated by the na. tives generally.

Cucuris Melo.

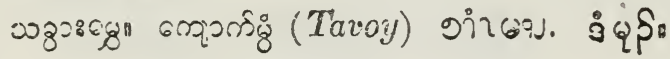

CHESTNUT.

There is an indigenous chestnut tree growing on the uplands which yields abundantly, and whose fruit is sold in bazar, but they will not compare with the Frencl chestnuts, nor even with the American chincapins.

Castanea martabanira.

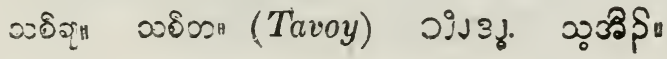




\section{FETID STERCULIA.}

The foted sterculia is not uncommon in the forests, and its seeds are eaten like filberts.

Sterculia fetida.

coşिर्ड

\section{BOODH'S COCOANET.}

A handsome tree bearing a large fruit, called Booch's cocoanut is met with in the Provinces, whose winged seeds are sometimes eaten by the natives.

Stcrculia alat 7 .

PEA NUT.

Ground uuts are abundant in the bazars, and are consumed in large quantities by the natives. The plant is occasionally seen growing, but the nuts are principally imported from Pinang and Rangoon.

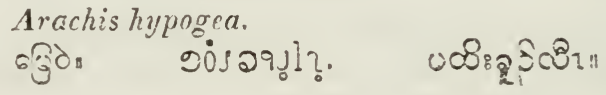

SANDORICTH.

The sandoricum tree bears a fruit the size of an orange, occasionally called the wild mangosteen, to which it bears some resemblance. It has a fleshy acid pulp and makes a rery good jelly, but has a peculiar odour. The natives eat the fruit raw, and esteem it excellent.

Sandoricum indicum.

côo:"

62.

203

WIILUGIBEIA.

There is a species of willughbeia in the forests that proo duces a fruit as large as an apple, which Europeans sometimes call "a kind of a fig." It has an agreeable taste but abounds in a milky juice.

Villughbcia martabanica. 


\section{RED NEPHELIUM.}

This is a small inferior fruit, eaten by the natives only, though belonging to the same genus which produces the famous lichi, and bearing its fruit in bunches like that.

Nephelium.

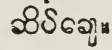

$$
\text { อ? दु?. }
$$

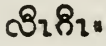

\section{TAMARIND.}

The tamarind is a large handsome tree, with spreading branches, and is worthy of care for its light beautiful green foliage, and profuse yellowish blossoms with veins of red, as well as for its fruit. It is an exotic on this Coast, but is planted by natives around their dwellings for the leaves, which being slightly acid, afford an agreeable condiment to their curries. I have seen the tree bearing richly in Mergui, but have rarely observed it yielding fruit abundantly in the-northern provinces. The dried fruit is imported in large quantities from Burmah, and is constantly for sale in the bazar.

Tamarindus indica.

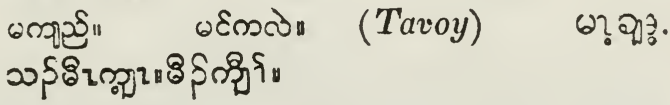

\section{CASHEW-NUT.}

The cashew tree bears an agreeable fruit, to which is attached the nut, both of which are common in the market.

Anacardium occident ale.

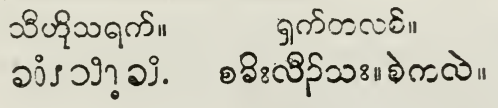

(Tavoy.)

JUJUBE.

The jujube from which the famous jujube lozenges are made, is a small sour berry, a great favorite with the Burmese and Karens. The tree is of middle stature, and is often found apparently growing wild.

Zizyphus Jujuba.

28. 6า 


\section{PHYLLANTHUS.}

There is a small tree very abundant at Maulmain, and in many other localities on the Coast, belonging to the genus phyllanthus which bears a small intensely sour fruit, that is valued by the natives.

Phyllanthus.

28.

INGA.

Native gardens are often ornamented with a species of inga which affords a thick beautiful shade, and when in flower its tufted boughs seem to bend under their burdens of sweet-scented blossoms. It is a leguminous plant, whose seeds are poisonous, and when taken into the stomach sometimes produce disastrous consequences, yet the Burmese and Karens are extravagantly fond of them, as a condiment to their preserved fish, and they bring a high price in the bazars.

Inga bigemina.

o $\varepsilon_{\| \prime}$

วถร์.

วิฐ

EDIELE ZALACCA.

A red scaly fruit produced by a species of zalacca may be often seen in bazar, but it is eaten by the natives only. Zalacca cdulis.

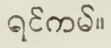
2ร?.
อริเ

FIG-TREE.

A stunted fig-tree or two may be seen in a few European gardens, but the fruit rarely comes to perfection; although there are perhaps more indigenous trees in the jungles belonging to the fig genus, than to any other in the whole regetable kingdom.

Ficus Carica.

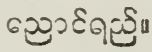
จุํํ่อำ.
จาวิวงั

INDIAN GRAPE.

There are three or four species of grapes in the Prorinces. One is seen creeping over erery hedge and bush, which has sometimes been mistaken by Europeans for the 
true grape vine; but the fruit is acrid, like all the indigenous species, ard not edible eren to a native.

Vitis indica.

คุहธงाहा

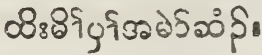

GRAPE VINE.

The grape vine many be seen in many of our gardens, but it very rarely produces fruit. I once saw a vine in Mergui, however, which had on it several fine bunches of grapes; and I hare heard of grapes being occasionally brought to perfection in Maulmain.

$$
\begin{aligned}
& \checkmark \text { itis vinifera. }
\end{aligned}
$$

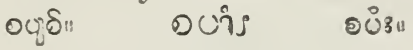

CHERRY.

Voigt says there is a species of cerasus, or cherry "a native of Maulmain," but I have never happened to meet with it. He had however good authority for the statement; and Grimith remälis that there is in the Pro= rinces one species of the almond tribe, "which abounds in prussic acid."

Corasus.

WALNUTS.

Walnuts are occasionally brought from Rangoon; but it is not certain that they are the produce of the indigenous walnut tree.

$$
\begin{aligned}
& \text { Juglans arguta. } \\
& \text { ๗हீलु" }
\end{aligned}
$$

$$
\text { HoG's RLti. }
$$

' 1 'his is an intensely astringent fruit very appropriately named. The Karens have a tradition that in those Golden Days when God dwelt with men, all nations came before him on a certain day, each with an offering frorn the fruits of their land, and the Karens selected the hog's plum for their oblation; which gave such offence, that God cursed the Karen nation and placed it lowest among all the nations by whom they are surrounded.

\section{Spondias mangifera.}

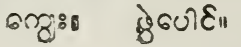

(Tavoy.)

09. 20े: 


\section{COCOANUT.}

The cocoanut is one of the most valuable of tropic fruits and the milk of the young nuts is a very grateful beverage.

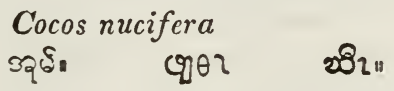

LOQUET.

The loquet is sometimes seen in flower around our bungalows, but 1 have never met with it in fruit.

Eribstrya japonica.

PEAR TREE.

Wallich found a species of pear tree growing on limestone mountains, near the Irrawaddy ; and it may exise in these Prorinces, though I have never met with it.

Pyrus.

J A CK.

The jack is perhaps more abundant than any other fruit, except the plantain. It is invaluable to the natives, but is an indifferent fruit to Europeans. The tree is large and affords a very dark grateful shade, and when the fruit, which is often as large as a man's head, is hanging all around its branches it is a grand object.

Artocarpus integrifolius.

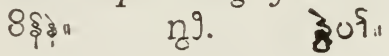

GREAD-NCT.

The bread-fruit tree is cultivated in a few gardens at Tavoy and Maulmain, and bears very well; but the fruit is of that variety which is full of seeds and is of no value. Artocarpus incisus.

\section{BREAD-FRUIT.}

The true seedless bread-fruit tree is cultivated at Penang, and has recently been introduced into Mergui, where it is said to flourish.

Artocarpus communis. 
MOUNTAIN JACḰ.

There is an echinated, agreeahly acid fruit produced $b_{y y}$ a large tree, which the Burmese call the mountain jack. The leares of the young trees are gashed like: some species of oak. One of our Tavoy surgeons transplanted a tree to his own garden, under the impression that it was $A$. incisa, the breadfuit tree, not being aware that in old trees the leaves are entire.

$$
\begin{aligned}
& \text { Artocarinus cchinatus. }
\end{aligned}
$$

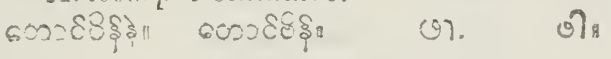

I.ATOOCHA BREAD-FRUTT.

"lhis fruit is usually designated by Furopeans "a kind of a fig: " but it is a species of artncarpus, occasionally yaised near mative houses.

$$
\begin{aligned}
& \text { Artocrerpus Lizcouchr. }
\end{aligned}
$$

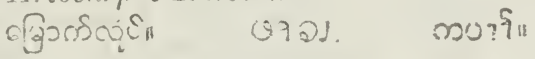

HART BREAU-FELT.

'I'his indigenons fruit resenbles the preceding, in erery respect, except that it is covered with soft weak hairs.

$$
\text { Artorrarpus hirsutus. }
$$

SMALL BREAE-TRCIT.

This is an orange-colored fruit resembling in iaste it custard apple, and in appearance a fig, but it is a speci of artocarpus, which 1 cannot find any where describ? " though not scarce in our forests.

\section{Artorcirpus.

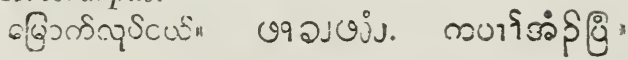

\section{MORINDA FRUIT.}

A species of morinda is often seen growing near Burman houses, which produces a fruit as large as a pullet's egg. It is a great favorite with the Burmese, and is scred up in their curries.

$$
\text { Morinda. }
$$




\section{HOG-CHESTNLT.}

Lvery one has heard of the horse-chestnut, but fer are probably aware that in these Provinces the hog-chestnut is indigenous. Such is a literal rendering of the Burmese name, and the tree is certainly a species of chestnut, but it is not described in any of the books to which I can refer.

\section{Castanca.}

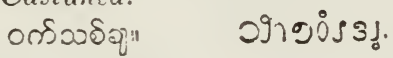

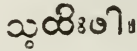

CHINESE DATES.

"The Burmese," says a correspondent who resided several years in Ava, "call the Chinese fig, which is brought in great quantities orerland to Ara, tee-thee or fay-thee*." This is the same fruit which in England is called Chinese date; but is neither a fig nor a date, but the fruit of a species of ebony ; and a more appropriate name would be the Chinese persimon, the persimon tree being also a species of ebony, and there is a consideras ble resemblance in the fruit.

The tree which produces this "Chinese date," is occasionally cultirated by the Burmese, but it bears fruit very sparingly, and I think with Roxburgh, that it is "by no means equal to a good apple."

\section{Diospyros Káki.}

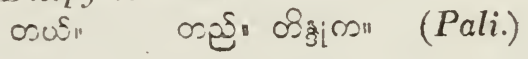

\section{MINUSOPS FRLIT.}

A drieri fruit is occasionally seen anong the Chinese, brought from Singapore, and some of the seeds produce trees, which, judging from their leares, can be no other than

$$
\text { Nimusops Kauli. }
$$

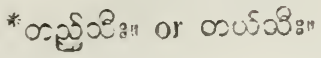




\section{VEGETABLES.}

There is a great variety of vegetables indigenous or culs tivated in the Provinces; but the best are scarce, and rarely for sale in the bazars. Nearly every plant produces a regetable for the riatives. The Burman books say, there are ten kinds of vegetables, or pot herbs, corresponding to the parts of a plant that furnish them.

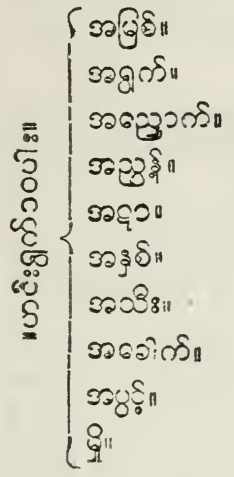

-the root

- the leaf

- the sprout

- the shoot

- the tuber

-the heart

-the fruit

- the bark

- the blossom

-mushroom

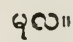

UR"

๓งิดุ"

अभु"

ms

Вื)

ucru

cos:

पÜ"

$\infty \mathbb{B}^{\mathrm{H}}$
(Pali.)

66

66

es

66

65

68

16

66

66

KAREN POTATOE.

This is a small yam not much larger than a kidney potatoe, which it much resembles both in appearance and taste. It is cultivated extensively by the Karens, and being more like a potatoe than a yam, has acquired the name of the Karen potatoe, and is sometimes called the Tavoy potatoe. It is the best vegetable we have, but unfortunately it can be obtained during a few months only in the year. I am not aware that it is ever found wild on the Coast ; and it appears to me to, be either identical, or nearly related to Roxburgh's

$$
\begin{aligned}
& \text { Dioscorca fasciculata. }
\end{aligned}
$$

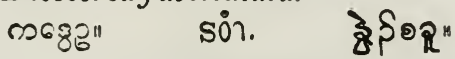

ELEPHANT-FOOT YAM.

A yam with a tuber about the size and shape of an elephant's foot, ranks next to the preceding species. It is 
white, and often as light and agreeable as a potatoe. It abounds in Karen gardens but is rarely seen among the Burmese, or in the inarket.

\section{Dioscorece.

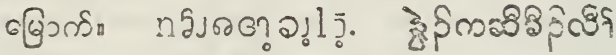

LARGE WHITE YAM,

There are several different species and rarieties of white yams in cultivation. 'The one most in repute has arrowheaded cordate leaves.

$$
\begin{aligned}
& \text { Dioscorca globosa. }
\end{aligned}
$$

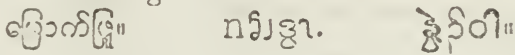

DARK PURPLE YAM.

A yam with a dark purple root is one of our best yams, and is extensively cultivated both by Karens and Burmese.

Dioscorea atropurpurea.

$$
\text { बदुग }
$$

WILD YAM.

There are several indigenous species of yams, which are eaten by the Karens in times of scarcity, though very acrid. One is remarkable for its large ternate leaves, of which its leaflets are sometimes nearly a foot long, and six inches wide.

Dioscarea damona.

$$
\text { लำ ฤำ. วั" }
$$

SWEET POTATOE.

The sweet potatoe is very abundant but it is vastly inferior both in size and quality to the sweet potatoe of the Southern States of America.

Batatas edulis.

Convolvulus batatas.

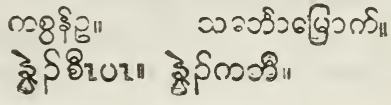

กรงอยูน. 
TELINGA POTATOE.

This is a plant of the arum tribe which produces tubers like a yam, much esteemed by the natives; and is very generally raised by Burmese and Karens.

Amorphopleallus campanulatus.

Arum campanulatum.

CII Q0ำ. 2071

COLOCASIA.

This is another plant of the arum tribe which is grown by the natives for its tubers, that supply the place of potatoes.

Colocasia antiquorum.
טई口
ขวงจั?
Qโ 3111

COMMON POTATOE.

The potatoe is of easy culture but the tubers are rery smail, and it is not an object of cultivation;- ihough with a little attention, it might possibly be made one.

Solanum tuberosum.

PEA.

The pea is seen in European gardens, and produces very woll in some localities.

Pisum sativum.

GOA BEAX.

There is a variety of the Goa bean which produces esculent roots that are eaten like potatoes, and are a very tolerable vegetable. The young pods are also eaten like French beans.

Psophocarpus tetragonolobus.

Dolichos

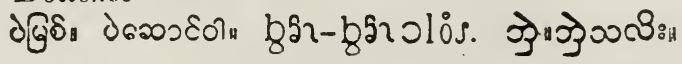




\section{SWORD BEAN.}

The sword bean is planted to a small extent, and its young pods are used as a vegetable.

Cianaralia gladiata.

Dolichos gladiatus.

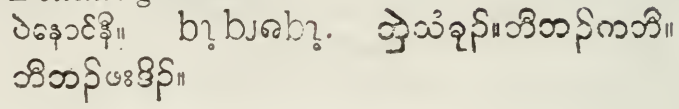

INDIAN LIDNEY BEAN.

Burmese and Karens grow several varieties of one or two species of lablab, which occupy the place of kidney beans in Europe.

Lablab vulgarc.

Dolichos lablab.

d. b? bs.

วิธง

NATIVE BEA N.

The natives cultirate another bean which resembles the common European bean, and is esteemed by them a good regetable.

Cyamopsis psoraloides.

Dolichos fabaformis.

dugई" b? bjoîl.

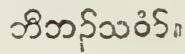

BLACK GRAM.

Crawfurd says that one of the most common pulses seen in Burmah is the Phascolus max; which is the plant that produces the black gram of India.

Phascolus Mungo, melanospermus.

Ilax.

, ${ }_{*}$

MELILOT.

Griffith saw large fields of melilot in the neighborhood of Ava, but I have not seen it in these Provinces.

Melilotus.

d. 
AGATI.

The legumes of the agati are a farorite vegetable with the natives, and the trees, which grow very rapidly, may be seen in perhaps every town and village in the Provinces.

Agati grandiflorum.

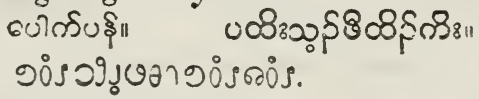

CHICKPEA.

The chickpea, or gram, is grown extensively by the Burmese, especially in Burmah, and large quantities are imported into the Provinces from Rangoon.

Cicer arictinum.

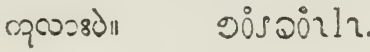

$0088 \cos 2002 \pi$

\section{DOLL.}

The doll bean is raised to a small extent, but the doll sold in market is principally imported.

Cajanus indicus.

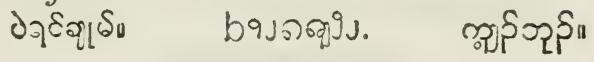

WILD FRENCH BEAN.

A species of phaseolus, the genus which furnishes the common French bean, grows spontaneously everywhere in the Provinces. Roxburgh describing the species says, that he never found it "but in its wild state;" while Voigt is made to say, by a mistake of the printer no doubt, "Cultivated, in which state only it was found by Dr. Roxburgh."

$$
\begin{aligned}
& \text { Phaseolus trilobus. }
\end{aligned}
$$

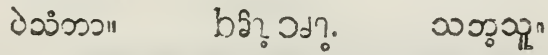

WILD DOLICHOS.

An indigenous species of dolichos with downy leaves and pods, abcunds in some sections of the country.

Dolichos pilosus.

coseco

b? bง 29 ?.

วิธว พิ่าน 


\section{WILD SWORD BEAN.}

On the sea shore a wild species of sword bean is found growing in great profusion.

Canavalia virosa.

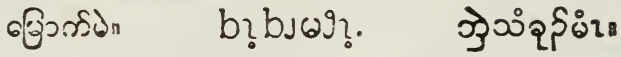

HORSE-RADDISH-TREE.

The horse-raddish-tree is propagated by the Burmese for its pods, which are eaten in curries; but it is chiefly valued by Europeans for its roots which cannot be distinguished when eaten with roast beef, from the common horse-raddish, Cochlearia Armoracia.

Moringa pterygosperma.

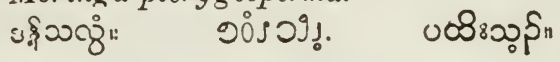

ASPARAGUS.

Tre common English asparagus is sometimes seen in European gardens, but it is very unproductive.

Asparagus officinalis.

WILD ASPARAGUS.

There is an indigenous species of asparagus, which produces a passable substitute for the English vegetable, to which however, it is much inferior. It bears a sweetsmelling flower, and is deserving of cultivation as an ornamental plant.

Asparagus accrosus.

g)

ripl.

§ิเ

CABEAGE.

One of the most highly esteemed vegetables of European gardens is the cabbage, which is raised from imported seed, and fine plants are sometimes produced, but they are sel. dom in the market.

Brassica oleracea.

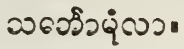


TERNIPS.

Turmips are occasionally grown, but they do not re. ivard the cultivator so well as cabbages.

\section{Brasica Rapa.}

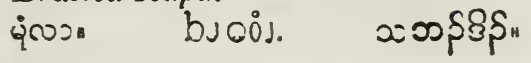

RADDISH.

$R$ addishes abound in regetable gardens, and are almost always in the bazars.

Raphanus sativus.

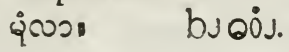

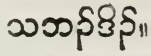

MUSTARD.

I have seen a species of mustard on the banks of the Tenasserim, several days jou!ney from any human habitation, and which the Karens regarded as growing spontaneously, but it did not appear to differ from the species in common culture on the Coast, and the seeds had probably becn dropped there by the passing traveller.

Sinapis.

ईंखृहः u

bJQ⿻่s.

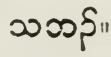

WATER CRESS.

Griffith says he found an indigenous species of nasturtium in the Provinces, but he does not appear to have described it.

Vasturtium.

GARDEN CRESS.

A mong the dried seeds sold in bazar for medicinal purnoses, are the seeds of the common garden cress.

Lepidum sativum.

oł?s:

RED GUURD, OR SQUASH GOURD,

A species of large pumpkin or gourd, is a common rege. rable seen on the tables of Europeans. "When boiled," -ays Wight, " it resembles in taste a fine tender carrot."

Cucurbita maxima.

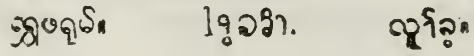


WHITE GOURD; OR PUMPKIN.

The Karens and Burmese cultivate a species of pumpkin or gourd, never eaten by Europeans, which they esteem a valuable addition to their curries.

Benincasa cerifera.

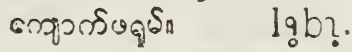

ฉโริด

SNAKE GOURD.

A curious contorfed gourd, peculiar to India, is in very general demand for vegetable curries. The plant is of easy culture on trellises around the doors of the native cabins, and the fruit often grows two feet long, beautifully striped, small, and tapering, so that streaming down from the trellis, they immediately remind one of striped snakes suspended from the foliage of trees.

Trichosanthes anguina.

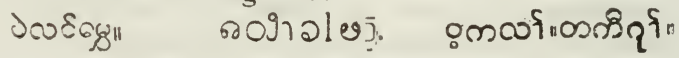

BITTER GOURW.

This is a very bitter gourd of the same genus as the preceding, but unlike that, this is eaten by the natives only.

Trichosanthes cucumerina.

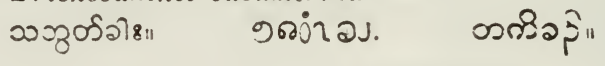

BOTTLE GOURD, OR WHITE PUMPKIN.

The bottle gourd grows luxuriantly, and several variefies may be seen about our Indian cabins.

Lagcnaria vulgaris.

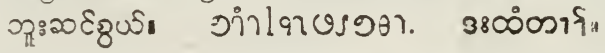

PENTANDROUS LUFFA.

This is a long gourd with a striped skin, considered by the natives a delicious vegetable.

Luffa pentandra.

एकृ⿰丿

sc30:08. 


\section{ANGULAR LUFFA.}

This luffa gourd has ten sharp ridges by which it may be easily recognized, and Roxburgh says that with a little butter, pepper and salt, "it is little inferior to green peas."

Luffa fatida.

Luffa acutangula

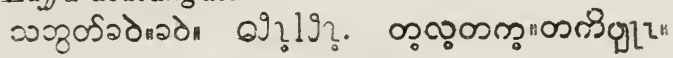

\section{MOMORDICA.}

Two or three varieties of momordica, a fruit the size of a cucumber covered with tubercles, are used in curries.

Momordica Charantia.

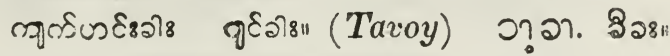

\section{DIOECIOUS MOMORDICA.}

A species of momordica with small muricated fruit, is occasionally eaten by the natives.

Momordica diceca.

ough,

งาำงรา.

ษ்ำ

\section{CUCUMBER.}

Cucumbers are consumed in immense quantities, but the $\mathbb{K}$ arens and Burmans seem to prefer them when large and yellow, rather then pluck them when green and tender.

Cucrmis sativus.

"utilissimus.

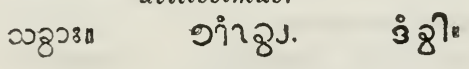

BRINJAL.

The vegetable egg, or brinjal, is one of the best vege 1 ables in India. Several varieties are extensively cultivated and eaten by all classes.

Solanum Melongena.

จดุิ

e?.

วกหิి" 
romato.

The tomato or love apple, another of our delicious vegetables, abounds in $\mathbf{A v a}$, and is cultivated to a limited extent in many of nur gardens.

Lycopersicum esculentum.

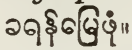

วกหิrußr"

\author{
OKRA.
}

The okra plant of the Southern States of America, as universally abounds in these Provinces, and all orer the East, as it does in the West Indies.

Abelmoschus esculentus.

Hibiscus

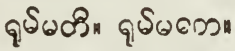
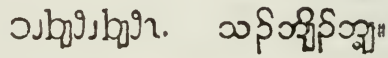

MALABAR NightSHADE.

This is a twining plant, with succulent stems and leares, that the Burmese cultivate for spinage; and it is said to be not interior to the common English spinage, which belongs to the same natural family.

Basella alba.

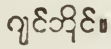

NEPAUL SPINAGE.

Several varieties of the edible amarantus are cultivated and eaten like spinage, and are sometimes denominated Nepaul spinage. Roxburgh says of one variety: "The tender succulent tops of the stems and branches, are sometimes served up on our tables, as a substitute for asparagus."
Amarantus oleraceus.
usengust.
Q2s!?
ตอเงิ"

SPINOUS AMARANTUS.

A spiny species of amarantus grows spontaneously and is a common weed in some parts of the Provinces, which the natives use for a pot-herb.

Amarantus spinosus.

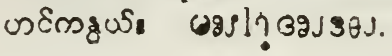

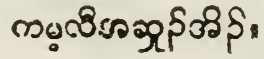


ONION.

The common English onion is sometimes cultivated, but the principal part of the onions seen in the bazars are brought from $R$ angoon, and it is believed are of a different species.

Allium ascalonicum?

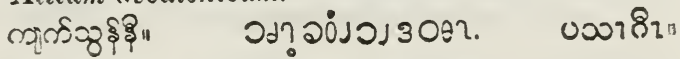

\section{LEEKS.}

The native inhabitants of Tenasserim are as much ato zached to leeks, as the Israelites were to the leeks and onions of Egypt, and they abound in their gardens.

Allium Porrum.

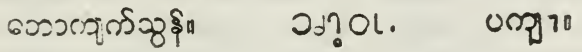

\section{purslane.}

Pursiane is as common a weed in these Provinces as it is in America, and is used by the natives for a pot-herb.

Portulaca olcracea.
बुिप्रु०

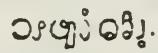
aรgio

WATER DILLENIA.

A species of dillenia always found on the borders of streams, hence called water dillenia by the Karens, produces a large fruit, which is brought to bazar green, and considered a favorite regetable with the natives.
Dillenia.
$\omega \mathrm{s}^{\circ}$
Ogas.

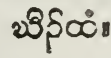

ВАMBOD SHOOT.

The young shoots of some species of bamboo are sold in market for a vegetable. They are also used by Europeans for a pickle, and a preserve.

Bamura.
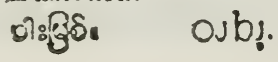

o โุริด 


\section{SEDGE ROOT。}

The roots of a species of sedge are found among the regetables, though they taste like filberts.

Cyperus.

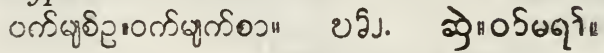

\section{LETTUCE.}

Lettuce is cultivated to a limited extent by Europeans. Lat tuca sativa.

\section{MUSHROOM.}

Mushrooms are often seen in the bazar, and the Karens hare names for sixty-four different species of mushronms and the allied fungi. They distinguish the edible from the poisonous kinds, they say, by touching them with the lime that they eat with the betel. If the fungus turn red when touched, it is regarded as poisonous. But they are so careless or ignorant, that sickness and death often ensue after eating them.

$$
\begin{aligned}
& \text { Fungales. } \\
& \text { ओं ขd?. का }
\end{aligned}
$$

SPATIIUM ROOT.

'There are one or two species of spathium, plants that grow in the water; one ( $f$ which Voigt says, is found on the banks of the Irrawaddy, and has roots " nearly as good as potatoes."

Spathium chinense.

\section{CAPSICUA.}

Large quantities of Cayenne-pepper, or chillies, of which we have two or three species, enter into all the native dishes: not in the form of pepper, but the fruit stewed or roasted is eater with the food.

Capsicum.
cดูर्ड
ॐกริ.
ธินอว 


\section{CEREALs.}

The cereal grasses commonly grown within the tropics, do not appear to be as nutritious as those of temperate climates. Rice and millet are not equal to wheat and oats. The Burman books say, there are seven kinds of $s a b a$, or cereals, in which they include pai or beans.

\begin{tabular}{|c|c|c|c|}
\hline 2mon & rice & & (Pali.) \\
\hline c): & 6 & " & « \\
\hline CQ8 3056 & wheat & 6nीqü & " \\
\hline Q600ว" & barley & $\omega$ & 66 \\
\hline बత్రિગ $\varepsilon_{\|}$ & millet & & 6 \\
\hline $20^{31}$ & aspalum & $n \widehat{్}[\omega n$ & \\
\hline $20 S_{u} m$ & panicum & మகీ|" & \\
\hline be & and peas & ァงคณタ" & \\
\hline
\end{tabular}

RICE.

Rice is universaily cultivated, and cultivation has produced many varieties. The Karens have distinctive names for more than forty, and Karen mountain rice is preferred by many to that which is raised by the Burmese on the low lands ; yet it is said not to be so nutritious, and on this account bears a less price in bazar. It is of all colors from irory-white to coal-black.

Of the black rice the Karens prepare a kind of bread, which to them supplies the place of gingerbread. A portion of seethed rice is poured into a large mortar with a prodigious quantity of sesamum seeds. "T'wo women then take their strong ebony pestles and pound it, striking alternately until it becomes a light bounding mass. It is then thrown upon the eating stand, when the whole family seat themselves around it in oriental style, and disserer it with their sabres.

The Karens have another mode of preparing this kind of rice, which is particularly convenient for travellers. A quantity unboiled is thrust into joints of small bamboo, a 
little water added, and the orifice closed up. It is then roasted, and if eaten with a little butter and salt it is most delicious. The Karens select only two varieties of bamboo for this purpose, and these impart to the rice a sweet delicate flavor.

Oriza sativa.

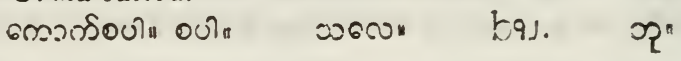

HOLCUS MLLET.

A species of millet of the Linnean genus holcus, is often grown by the Karens, and occasionally by the Burmese. This is the millet designated in Ezekiel 4:9.

Sorghum vulgare.

Holcus Sorghum.

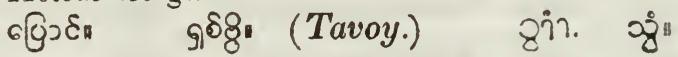

PANICUA MLLET.

One or more species of millet belonging to the genus panicum, are raised to a limited extent.

Panicum.

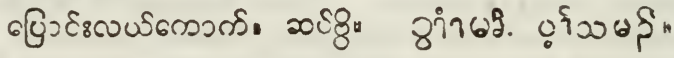

\section{SORGHUM MILLET.}

A millet plant is ocasionally seen, which in the United States is called "broom-corn," it being there manufactured into brooms.

Sorghum saccharatum.

धुगहร:

\section{COIX MILLET.}

A species of coix, Tob's tears, has large esculent seeds which are parched, like Indian corn in America, and, they are often for sale in the bazars.

Coix indica?

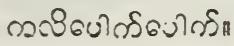

0.9.

نी 1003 


\section{MAIZE .}

M aize, or Indian corn is more generally grown than millet, and "green corn" is a common article in market, but it is hard and insipid, decidedly inferior to Americ an corn.

$$
\begin{aligned}
& \text { Zea Mays. }
\end{aligned}
$$

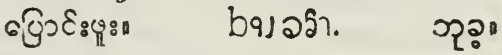

WHEAT.

Wheat is grown largely in Burmah, but $I$ have never seen it under culture in these Provinces, although Commissioner Durand made an attempt to introduce it. I have no doubt, however, but on the Karen mountains the cultivator would reap an ample harvest.

Triticum vulgare.

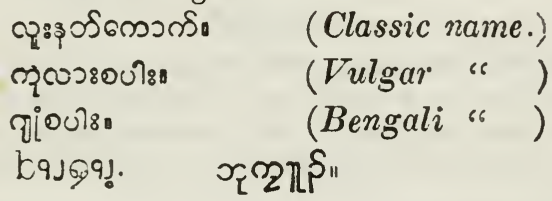

BA RLEY.

"This last grain," says Crawfurd, speaking of barley, " is not known to the natives, and when we pointed it out, they imagined it to be unripe grains of wheat." Notwithstanding this testimony, the Burmese have a name for barley which frequently occur sin their books. It constitutes one of their seven kinds of saba or cereal grasses, and its corresponding Pali name is identical with the Sanscrit name of barley.

Hordeum hexastichon.

घ६00ว

BAMBOO SEED.

In times of scarcity the seeds of the bamboo have often been used by the Karens as a substitute for rice.

Bambusa.
เาะ
Os.
o 


\section{GRASSES.}

Griffith collected nearly one hundred different grasses $11 \mathrm{t}$ the Provinces, but I am not aware that the description of a single species has ever been published.

\section{CHRYSOPOGON.}

The most common grass on the Coast is a species of the modern genus chrysopogon, concerning which, Roxburgh well remarks : "Its seeds are exceedingly troublesome to those who walk where it grows, as they stick in the stockings, and produce a disagreeable itching."

Chrysopogon acicularis.

Andropogon.

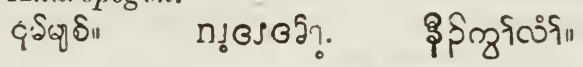

\section{PANIC GRASS.}

Several very common grasses belong to the genus panicum. One species grows about three feet high, and after a field has been subdued, it will often spring up so thick that every thing else is destroyed. Cattle eat it both dry and green.

\section{Panicum.}

CREEPING PANICUM.

A creeping species of panicum is one of the most abundant grasses on the Coast, but it is much less conspicuous than many others.
Cynodon Dactylon?
Panicum.

GUINEA GRASS.

Guinea grass is grown by a few Europeans, and it does as well as the indigenous species.

Panicum jumentosum

ANDROPOGON.

Several species of andropogon, as the genus is described by Roxburgh, are among our most abundant grasses.

Andropogon. 


\section{SE'TARIA.}

A species of setaria, which the Karens call "horsetail grass" is scattered all over the Provinces.

Setaria.

\section{ELFUSINE.}

'Tufts of eleusine are conspicuous every where among cther grasses.

Elcusine indica?

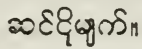

نำไิ:4

MEADOW GRASS.

Meadow grass has one or two representatives among our most conspicuous grasses.

Poa.

PASPALUM.

One or more species of paspalum are products of our fields. Paspalum.

ANTHISTIRIA.

In the Karen jungles I have noticed a latge grass with lax panicles and very long awns belonging to this genus. Anthistiria.

INUIA CLOVER.

The most valuable grass in the country is not a proper grass, but, like the English clover, is a leguminous plant. It is a species of hedysarum, "which in India," says Dr. Wight, "supplies the place of the species of Trifolium and Hcdicago in Europe." In other words, the farmer finds it a good substitute for clover and lucerne; and there is another leguminous plant at Tavoy, Smithia smsitiva, which is said to make "excellent hay." 


\section{MEdicinal PLANTS,}

The Provinces are rich in medicinal plants, both in number and quality. Lindley's Flora Mledica contains descriptions of all the known medicinal plants in the world, and more than a tithe of the whole number may be seen growing on the Tenasserim coast. Were we deprived of European drugs, and left to our own resources, we could find good substitutes for almost every article in the Mledical Flora:

Besides those to which separate paragraphs have been allotted, the bark root of the red cotton tree, and the roots of the clitoria are emetic; and the root of Tylophora vomitoria has been pronounced by Indian practitioners not inferior to ipecacuanha for any of the purposes to which that medicine is applied. Cassia fistula pods, the chebula fruit, the root of the heart seed, the seeds of the sapodilla, Otaheite gooseberry, and physic nut are aperient or purgative. The gum of the white cotton tree, the bark of Wrightia antidysenterica, and the peel of the mangosteen are prescribed in bowel complaints. The green fruit of the papaya, the root of the Persian lilac, and the fruit of the Rangoon creeper are vermifuges. The bitter roots of Sicla acuta, and Tephroia purpurea, and the seeds of the musk-mallow or musk plant, are deemed cordial and stomachic, and the bark of Guilandina Bonduc, is considered a good substitute for cinchona where that cannot be had. The decocted leaves of the goat footed ipomœa are used as an external application in cholic. The leaves of Vitcr trifolia are applied in diseases of the spleen. The bark of the white plumbago root will raise a blister, it is said, almost as quickly as cantharides.

The oil of the cashew nut " has been used successfully in eating off ring-worms, cancerous ulcers and corns." The mango tree exudes a large quantity of gum-resin resembling bdellium, and our indigenous pine can furnish any quantity of turpentine. The bark of the root, the lesves, and the fruit of the Bengal quince, are as popular 
with the natires, as the root, bark, flower, and fruit of the pomegranate, which have been famous for their medicinal properties ever since the days of Celsus.

\section{GAMBOGE. *}

Three works in my possession describe gamboge, each as the product of a different tree; a fourth represents all to be wrong, and a fifth suggests a cifferent plant still. One refers it to Cambogia gutta, a plant which, as described by Linnæus, has probably no existence. He described a Ceylon plant, "and it is now quite evident," says Dr. Wight, "that the character of the flower and ovary is taken from one specimen, and that of the fruit from a different one, owing to the imperfection of his specimens, and his not being aware, that the lobes of the stigma afford a sure indication of the number of cells of the fruit."

Another, refers it to Garcinia Cambogia, but Dr. Wight says, that the exudation of this tree is "wholly incapable of forming an emulsion with the wet finger," a statement known to be correct. The tree is very common in the 'Tenasserim Prcvinces, but the bright yellow exudation it produces, is certainly not gamboge.

A third, refers it to Stalagmitis Cambogioides, but Dr. Wight remarks: "The juice of this tree differs so very widely in its qualities from good gamboge, that it can never be expected to prove valuable as a pigment."

Dr. Graharn has described a Ceylon tree under the name of Hebradendron Cambogioides, which is said to produce good gamboge; but no gamboge has ever been exported into the English market from Ceylon. Thus it would appear, to use the language of Dr. Wight, that "the tree, or trees, which produce the gamboge of com. merce, is not yet known."

Dr. Helfer, who was employed by government as a scientific naturalist in these Provinces, reported: "The gamboge of this country dissolves very little with water, and consequently does not yield a yellow emulsion as the common guttifcra. It will never serve as a colour,

\footnotetext{
- Extracted from an article communicated by the author, in the Journal of the Asiatic Society for July $1 \$ 17$.
} 
but promises to give a very beautiful varnish." "This statement was controverted by a writer in our local periodical at the time, "ho said he had obtained "fine gamboge of the very best description" from our jungles; in which he was no doubt correct, but he erred when he added, that it came from the "true Stalagmitis Cambogioides ;" for that plant has a quinary arrangement of its Howers, while the arrangement of the flowers in those that produce gamboge, in these Provinces, is quaternary.

The hills that bound the valley of the Taroy river, on both sides, fiom their bases to their summits, abound with a tree which produces a bright gamboge. It is Rox. burgh's Gurcinia pictoria, which he knew produced gamboge, but which he said was liable to fade. As soon as I had satisfied myself of the identity of the trees by an examination of the inflorescence of our plant, compared with Roxburgh's description : I coloured a piece of paper, one band with this gamboge, and another with the gamboge of commerce: and subsequently exposed both to the weather equally for more than twelve months, but witheut being able to discover that one faded any more than the other.

South of the month of ' $\mathrm{T}$ avoy river, and throughout the province of Mergui, there is found on the low plains at the foot of the hills, and on the banks of the rivers, almost down to tide waters, another species of garcinia that also produces good gamboge. I have no doubt but it is the tree from which Dr. Griffith furnished Dr. Wight with specimens, and of which, the latter says, "I refer doubtfully to Wallich's G. cllipticr." We will call it then G. elliptica, a species which $\mathrm{D}:$. Wight has on his list of " species imperfectly known." The foliation and female fiowers are, howerer, very well described, and to complete the description, I may add, the male flowers are pedunculated, but the peduncles are short, and they might be characterized as sub-sessile. The anthers, like those of the female flowers, are sessile, depressed or flattened above, and dehisce circularly. The ripe fruit is globose, and not furrowed.

Neither Wallich, Wight, nor Griffith appear to have been at all aware that gamboge was a product of this tree. 
Dr. Wight, in a recent number of his Neilgherry Plants, says: "Two species of the genus garcinia are known to produce gamboge, most of the others yield a yellow juice, but not gamboge, as it will not mix with water." 'The species which he has described as producing gamboge, and to which I suppose he refers, are $\boldsymbol{G}$. gutta, or $\boldsymbol{I}$. Cambogioides, (Graham,) and $\boldsymbol{G}$. pictoria, (Roxburgh.)

In its appearance to the eye, and in its properties as a pigment, I have failed to discover the slightest difference between the exudation of this tree, and the gamboge of commerce The Burmese priests use it occasionally to dye their robes, the Karens their thread, and it serves equally well in colouring drawings. It is also used by the native doctors in medicine, but not extensively.

Dr. Lindley, in his new work the Vegetable Kingdom, says : "The best gamboge comes in the form of p'pes from Siam, and this is conjectured to be the produce of Garcinia Cochinchinensis." Now as G. clliptira is spread all orer the province of Mergui, is it not.probable that it also extends into Siam, and that the Siamese gamboge is the product, a part at least, of this tree?

Specimens of the gamboge were sent up with the above communication to Calcutta, and the Secretary of the Asiatic Society wrote in reply: "Our best botanist: here, consider that you have hit upon the true tree at last."

Garcinia clliztica.
w\$oא 005 ॥
Garcinia pictoria.
ojsb? 69.

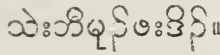
a) 3 रु.
ถรัดรา 505.
ذว

\section{CAMPHOR.}

One of the most abundant weeds throughout the Provinces is a species of Blumea, that grows six or eight feet high with leaves like mullen, which, when bruised, emit a strong odour of camphor. Many years ago the 'Tavoyers informed me, that they were in the habit of making an impure camphor from the weed by a very simple process ; but Mr. O'Riley of Amherst was the first to inake a good 
article from it, and to bring it to public notice. He made more than a hundrell pounds, and the specimens which he sent to Calcutta were reported: "In its refined form, it is identical in all its properties with Chinese camphor."

The plant is so abundant, that these Provinces might supply half the world with camphor. Wherever the trces are cut down, this weed springs up, and often to the $\epsilon \mathrm{x}-$ clusion of almost every thing else ; so that an old clearing looks like a field under cultivation.

Mr. O'Riley sent flowering specinens of the plant to Dr. M'Clelland for identification, who forwarded them to Dr. Voigt of Serampore, and subsequently reported: " Dr. Voigt states that it belongs to De Candolle's genus Blumea, and is so far as he can see, a new species." It is withont doubt the same plant as that which appeared in Wallich's Catalogue a quarter of a century ago, as Conyza grandis, and which De Candolle subsequently described as Blumea grandis. Wallich's specimens were from 'Taroy, without flowers, and DeCandolle describes the leaf as nine inches long with the petiole, by thiree wide, (" cum pctiolo 9 poll. longa, 3 poll. lata,) serrated, and bearing on the petiole tive or six remote linear acute lobes, ("petiolo lobulos -6 distantes lincares acu'es gercratibus,) which corresponds very accurately with some specimens of our canphor plant, but it does not correspond to any other species of Blumea in the Provinces with which $\mathrm{I}$ am acquainted.

Blumea grandis.

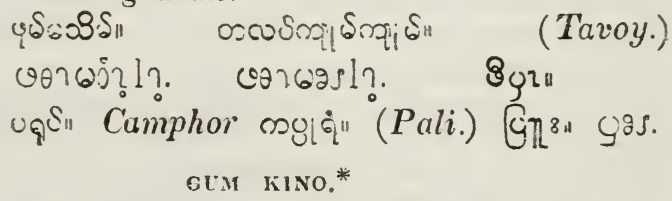

Dr. Royle, in a valuable article on gum kino, ostensibly enumerates all the various regions from which it has beell imported into England; but does not mention it as being a product of the T'enasserim Coast. Yet long before Dr. Royle compiled that communication, more than one

Extracted from an article communicated by the author, in the Journal of ths Asiatic Society for Angust 1848. 
consignment had been made by parties in Maulmain, to houses in London, of gum kino to the amount of a thousand pounds.

It was brought to Maulmain by an English merchant from the Shan States, and stated by him, as our Commissioner at the time informed me, to be the production of the pa-douk, the same tree as the one in Maulmain thus denominated by the Burmans. Several years before, I had directed attention to this tree as producing an astringent gum resembling gum kino, bis:t the medical officer, to whom I submitted specimens, said it was "a kind of dragon's blood." However, after Dr.Morton came to the Provinces, he tried it in his practice, and found it, in its medicinal virtues, identical with the gum kino of the druggists.

The next inquiry that arises is, for the genus and species of the pa-douk. When I first came to the Coast, all the English residents of my acquaintance called it "Burman senna," and the surgeon of the station told me that he believed it was a species of senna. Dr. Malcom, in his Travels, writes: "Pa-douk, or Mahogany, (Swittenia M(alogani) is plenty in the upper provinces, especially round Ava, found occasionally in Pegu." In a native Pali dictionary, found in the Burmese monasteries, pa-douk stands as the definition of pr-ta-tha-la, and the corresponding Sanscrit word in Wilson's dictionary, is defined pentaptera; but the pa-douk does not belong to that genus. In Piddington's Index, however, pectshala stands as the Hindee name, and in Voigt's Catalogue, pee:-sal as the Bengalee naine of Pterocarpus marsupium; and this brings us nearer the truth, for pa-douk is a name common to two different species of pterocarpus, but which look so much alike that they are usually regarded as one species.

One has "long, waving branches, with their extremities generally much drooping, racemes axillary, Howers numerous, deep orange yellow, and very fragrant, filaments ten [often] united into two equal distinct bodies of five each; stile rather shorter than the stamina; and stigma acute;" which is the description of $\boldsymbol{P}$. indicus : but on full examination I think it is the species 
described by Dr. Wight as $\boldsymbol{P}$. Wallichii thiat wa* marked in Wallich's Catalogue as $\boldsymbol{P}$. dalbergioides. 'There are, however, sereral points of difference, but not more than there are between Wight's description, and the coloured drawing that he gires of this same species. In the drawing, the leaflets are pointed wholly unlike our plant, but in the letter-press description there is an exact correspondence-in the drawing, the stamens are represented as divided one way, in the description another, and both modes of division, with some others, are seen here on the same tree. This loose way of describing and figuring plants makes it exceedingly difficult for an out-door botanist to identify nearly allied species with book descriptions, made perhaps originally from isolated dried specimens.

The other species has leaflets which correspond both to Roxburgli's description, and to Wight's figure of $\boldsymbol{P}$. dalbergioides; and though it differs in some other respects, yet I think it is the same tree.

Both these species produce an astringent gum, but which, has been exported for gum kino, or whether a mixture of both, which is most probable, I am not able to say: possibly neither. It may be that $\boldsymbol{P}$. marsupium is found in the Shan states, for it grows in Assam, where it would doubtlessly he called pa-douk by a Burman. Be that as it may, it is certain thit these Provinces can furnish the commercial world with a large quantity of gum kino. 'The exudation of our pa-douk, one of the most abundant forest trees, has been proved by experiment, to possess all the properties of gum kino, while the product of the neighboring provinces, whose only arenue to market is through our territories, has been bought by the London druggists for the gum kino of the Pharmacoperia.

$$
\begin{aligned}
& \text { Pterocarpus Wallichii. } \\
& \text { dalbergioides. }
\end{aligned}
$$

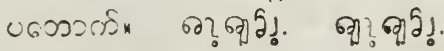

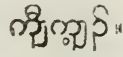

PLIAS KINO.

't he exudation of the butea tree, or pulas kino, when exported to Eingland a few years ago was recognized "as being the gummi rubrum astringes" of the old druggists. 
M. Guibourt of Paris, to whom some of it had been sent, states his opinion in his work on drugs, that it is the original " kino which had entirely disappeared from conumerce, and was once so much valued, as to be sold for nearly a guinea a pound." Amherst Province can furnish almost any quantity of the article, the tree which produces it being one of the most common denizens of our forests. Butea frondosa.

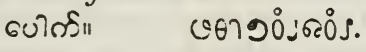

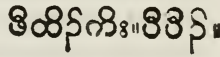

\section{DRAGON'S BLOOD.}

'There is a species of ratan in the forests, which the natives call "Red ratan," that produces a red exudation like dragon's blood.

\section{Calamus Draco? \\ तीई\$n \\ คงดษน. \\ กโริ?"}

\section{LIQUID AMBER。*}

"Did you ever see in this country the tree which produces the balsam of Tolı?" a gentleman once asked me. " No," I replied, "I never did." " I have one in my eom. pound," he continued; but unfortunately his compound was two hindred miles distant. Years passed away, and I found myself beneath this tree in flower, and soon dis. covered that it was not Myrospermum toluiferum, but Liquidamber Altingia; and that it produced not balsam of 'Tolu, but liquid storax.

The tree is indigenous on the Coast, and in some sec. tions is quite abundant. A considerable stream in the province of Mergui derives its name from this tree, in consequence of its growing so thick on its banks. It seems to have escaped the notice of Dr. Helfer, for, if I recollect right, it is not once alluded to in any of his reports, nor has it ever been brought to notice by any one; if we except a Catholic priest, a resident of $R$ angoon, who has introduced it in a little Burmese medical treatise, that was lithographed a few years ago by Col. Burney, who took a lithographic press with him into Burmah.

- Extracted from an article communicated by the author, in the Journal of the Asiatic society for June $1 \$ 18$. 
This gentleman, however, seems to have mistaken the tree, for he describes it as the one that produces the balsam of Peru, Myrospermum peruifirum, and which belongs to a different natural family. The medicinal properties of their exudations too, are materially different. Liquid storax, the production of this tree, is described by Lindley, merely as "a stimulating expectorant substance-influencing the mucus membranes, especially that which lines the air passages." 'The writer of the Burmese medical treatise recommends the exudation of the tree for the usual purposes to which the balsam of Peru is applied, under the illusion that it is the same substance!

Here is a fine illustration of the fallacies of medicine. It is probable that this balsam has been used in all the rarious cases many times by the author, and quite as much good done, and as wonderful cures effected, as if he had used the veritable balsam of Peru. And the same glorious effects are still being produced, for the book is in the hands of many natives, and is highly valued; but no part more so than this, because it points thern to a production: of the country, while most of the medicines mentioned are foreign products.

\section{Liquidamber Altingia.}

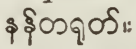

$$
\begin{aligned}
& \text { ทวัดดุร. }
\end{aligned}
$$

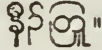

INDIAN GUM ANIME.

In Hindustan, Vateria indica produces a resin which is sometimes called copal in India, and gum anime in England; but it does not appear to be known that in these Provinces, another species of the same genus yields almost a precisely similar resin.

When in bloom the tree is quite ornamental, and diffuses the fragrance of its flowers for a great distance around.

Vatcria Roxburghii. consoso:n:

AMERICAN GUM ANIME.

The gum anime, or Courbaril locust tree, was introduced by Major Nacfarquhar, and is easily propagated.

$$
\text { Hymenaa Courbaril. }
$$


ALOES.

A species of aloes is often seen growing in gardens, and the drug is also imp orted from Hindustan.

Aloe soccotrina.

Q⿱宀

ASA FGTIDA.

Asafoetivia is much used by the Burmese doctors, but the gum is imported.

Ferula Asafatida.

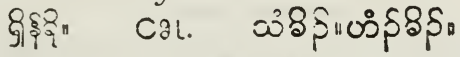

MANNA.

'I'here is a tree scattered on the Karen mountains, which III the dry season exudes a sweet substance resembling the mamua of the shops. I have observed it, in some instances, where it had dropped from the branches all around the base of a large tree like rain ; and again, where it had gushed out of the trunk like a large mass of gum arabic. I have never seen the tree either in flower, or fruit, but think it belongs to the myrtle 'ribe, a family that produces manna in New Holland.

\section{CINNAMON.}

The mountains that separate the valley of the Tenasserim from the waters that fall into the Meinam produce a species of cinnamon, the bark of which is equal to some of the inferior kinds of cinnamon, or cassia bark, thit is sold in the sliops. 'The Karens in Taroy sometimes col. lect.it, and chew it with betel.

\section{Cinnamon incrs.}

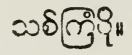

$$
\text { จะใดา }
$$

๓งาว"

\section{CLOVES.}

'The clove tree may be seen in a few gardens on the Coast, and clores are abundant in the bazars.

Eugenia caryophyllata.

Caryophyllus aromaticus.

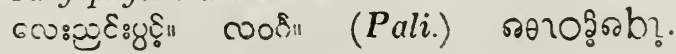
กิวโกวิ" 


\section{ALL-SPICE ?}

On the sides of some of the highest mountains in the province of Tavoy, I have repeatedly met with a tree, but never saw it either in fruit or flower, which the Burmese call "wild clore tree." The young branches and the leaves taste very strongly of all-spice.

Eugcnia. ('́imenta?)

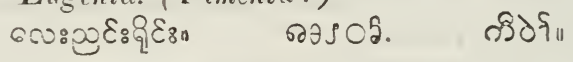

NUTMEG TREE.

Within a dozen years, the culture of the nutmeg tree has been sucessfully commenced both at Mergui and Naulmain. 'There are two or three large nurseries belonging to natives behind the hill at Maulmain, where the trees appear to thrive; and there is a plantation containing some thousands of trees at Mergui belonging to Baron des Granges, where the trees were beginning to bear several years ago; but the nutmegs can be imported from l'enang cheaper than they can be sold at a remunerative price in these Provinces, so there is little prospect of the spice plantation increasing.

Myristica moschata.
ब) छुछ
อรดานเขอา.
बร8c0i" (Pali.)
อ คนว요."

MACE.

Niace, which is the aril of the nutmeg, appears to have been originally regarded by the natives as its fiower, for its Burman name signifies "nutmeg flower."

$$
\text { a) } 80 \mathrm{~g} 10 \mathrm{~g} \text { : }
$$

\section{LIGN-ALOES.}

'T'he fragrant substance called lign-aloes, or wood-aloes, is offered for sale in all the bazars on the Coast, and is the produce of a tree that grows on the Mergui Islands. It is imported into Mergui by the Selungs, who, as they profit from the trade, endeavour to keep all in ignorance of the tree from which they obtain it. 
Gesenius says the Hebrew and Greek names are "derived from the Indian name of the tree, agil, Sanscrit agar'u and aguru." $\mathrm{Had}$ he read Pali he would have been able to approach the word nearer than he has done, through the Sanscrit, for there besides agaru*, the Sanscrit word, we have agalu and aggalu, $\dagger$ which come sufficiently near the "Indian name agil," and the Greek aggollochont; ; but it would take a pretty thorough Etymologist to get aloee, the $\mathrm{New}$ Testament word, out of any of them. 'There is, however, another Sanscrit and Pali word with which Gesenius does not appear to have met, lauha. $\$$ 'This is manifestly the parent of aloee, and by transposition, not uncommon in Hebrew, of the Hebrew name also.

Although rendered aloes in the English version, no two plants are more dissimilar than this, and the common aloes. Aquilaria Agallocha?

Alocxylon Aggallochum?

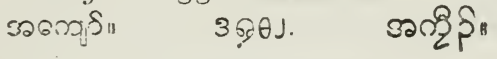

\section{SANDAL WOOD.}

Sandal wood imported from Hindustan is constantly for sale in the bazars, being a favorite cosmetic with Burmese ladies.

Sintalum albrum.
ogुm: mą)
ogş: (Pali.)
ริढ 6 วิน.
กดุेเ

WILD SANDAL WOOD.

An inferior kind of sandal wood is produced by a tree in the southern part of Mergui Province, ant forms an article of commerce.

Santalum.

कคุ छे:

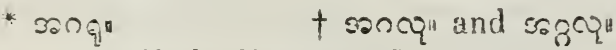

This:goes to show with other things, that the Greeks were connected in Irdia with those that spoke Palı rather than Sanscrit.

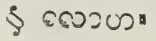


COSHETIC BARK.

The fragrant bark of a tree which is indigenuus in Burmah above Rangoon, is more universally used for a cosmetic than sandal wood. A single specimen has been shown me in Maulmain, which is a very ornamentil fragrant flowering shrub of the citron tribe.

Nurraya paniculata.

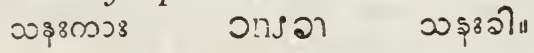

COS.METIC TUBERCLE.S.

An inferior cosmetic wood is seen in market, which is the tubercle of some plant. The Burmese appear, from their name, to regard them as produced by a species of erythrina, for they call them "erythrina thorns:" but I know the plant to be a creeper, and suspect that it is

Torldalia aculcata.

" floribunda.

nov

CRINU.M BUI.BS.

A dried fragrant substance is seen among the native drugs which is imported. No one seems able to tell what it is, but on tracing its Burman name through the Pali into the Sanscrit, I find Prof. Wilson defines it, with some doubt, as the bulb of a species of crinum.

Crinum.

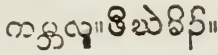

MERGUI COSMETIC WOOD.

There is a fragrant cosmetic wood sold in bazar, which is said to come from Nergui, but I never saw the tree.

Irathoxylacce? $\cos \varepsilon$ ऽ

\section{OPIUM.}

I hare never seen the poppy under culture, but opium is eaten to a very considerable extent by the Burmese, and the drug is easily procured.

Paparcr somniferum.

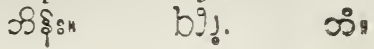




\section{BHANG.}

It is a singular fact that the hemp-plant in tropical countries exudes a gum, that is "a very powerful stimula. ting narcotic," which it does not produce in cold countries. The dried leaves under the name of bhang, partaking of this narcotic principle, are used all over India as a substitute for opium, to produce intoxicating effects. Under the Burmese government at Tavoy, no one was al. lowed to cultivate the plant without a licence from Government. Sometimes a general permission was given, and at other times a general prohibition would be issued.

Cannabis sativa.

๗॥॥

T OBACCO.

Tobacco, which was introduced from America within a few conturies, is now more universally used in Burmah, than it perhaps ever was in its native country. The Karens raise it for their own consumption, and the Burmese both cultivate it, and import it from $\mathbf{R}$ angoon.

Nicotiana Tabacum.

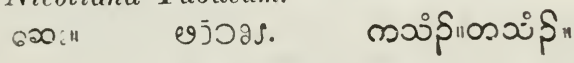

THE WUTE THORN APELE.

The white datura has little to recommend it in point of beauty, or pleasantness of association, yet we find it celebrated by Heber in his "Walk in Bengal."

$\therefore$ While to the cooler air confest

The broad datura bares her breast,

of fragrant scent, and virgin white,

A pearl around the locks oi night."

It is often seen blooming around native dwellings, and may possibly be used in T'enasserim for the same bloody purposes as in India. The common stramonium of Eu. rope and America " is perhaps only a variety."

Datura Metel.

Datura alba.

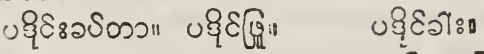

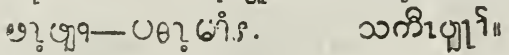


PURPLE FLOWERED THORN APPLE .

Both the single and double flowered varities of this species may be often seen near Burman houses, and children not knowing its poisonous character, sometimes eạt the fruit with very serious effects.

Datura fastuosa.

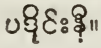

טำ ซาครา.

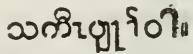

NUX VOMICA.

A Medical Botany before me says, the Nux vomica, or poison nut, grows "chiefly in Ceylon and Malabar, occupying sandy situations." It is a very common tree on the rocky sides of the hill back of Maulmain. The reputed property of the wood to cure the bite of venomous snakes, as stated by Lindley, is never heard of here, and is doubtless quite apocryphal.

Strychnos Nux vomica.

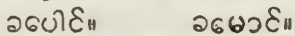

COCCULUS INDICUS.

This twining shrub, well known for its poisonous seeds, Dr. Helfer reports as indigenous in the Provinces, but I have never observed it.

Anamirta Cocculus.

SENNA.

I have never seen the true senna under culture, but the dried leaves are constantly for sale.

Cassia clongata.

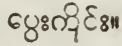

\section{FGTID CASSIA.}

The foetid cassia is one of the most abundant weeds in this country, and it has a place in the Materia Medica, because its leaves are used to adulterate Aleppo senna, and are said to be cathartic.

Cassia Tora.
उई ते०ः
จำดว?.
బீโญ 
WINGED CASSIA.

This species bears a profusion of gaudy, yellow flowers, and is much cultivated by the natives for its medicinal properties in diseases of the skin.

Cassia alata.

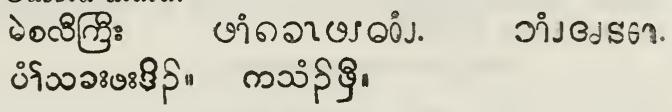

WESTERN CASSIA.

There is a small species of cassia that I have occasionally noticed in native cultivation for medicinal uses, which was originally introduced into India from the West Indies.

C'assia occidentalis.

nocusn

\section{COW-ITCH.}

The cowhage, or cow-itch, with its stinging pods is very common in the Karen jungles. I believe it is the common species, but I never met with the plant in flower.

Mucuna pruritus.

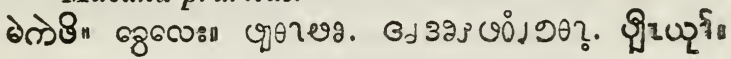
MYROBALANS.

Myrobalan fruit is esteemed medicinal by the Burmese, and is dried and sold among the drugs. The tree is indigenous, but not very abundant.

Terminalia Bellerica.

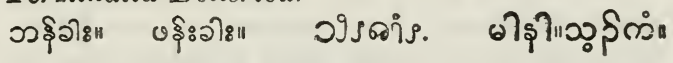

\section{BAMBOO-FUNGUS.}

There is a fungus like a mushroom that grows at the root of the bamboo in these Provinces, hence called the bamboo-fungus, which is regarded by the natives as quite a specific for worms. It has also been introduced into European practice, and is regarded by some physicians as superior to any anthelmintic in the Materia Medica.

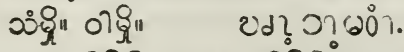

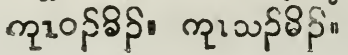




\section{IPECACUANHA.}

A pretty little annual, with a small saffiron and orangecoloured flower, is quite common, and is characterized as the "ipecacuanha-plant." It is not the true ipecacuanhaplant, but the root is emetic, and is used by the negroes of the West Indies.

Asclepias curassavica.

JEW BLSII.

This American plant, which is used in the West Indies as a substitute for ipecacuanha, is seen in cultivation occasionally, and in the neighborhood of Calcutta it is as abundant as a wild plant.

\section{Pedilanthus tithymalvide:}

MLDAR PLANT.

The mudar plant is propagated for its medicinal properties, which are said to be very numerous, and European practitioners recommend the juice of the plant in cases of leprosy above all other preparations. IVe have two varieties, one with a cream-coloured flower, and another with a black and purple tinge.

Calotrepis gigantca.

טक्षి॥

CAJUPLT-OIL.

An elegant little tree, with birch-like bark that produces cajuput-oil, is indigenous in the Karen forests of the southern provinces, but I have not observed it north of the ralley of Palouk river, in latitude about $13^{\circ}$.

Mclaleuca Cajuputi.

CASTOR-OIL.

'I'he Palma Christi, or castor-oil plant, is very extensirely propagated by the Karens, who have two or three varieties. Until they were informed, howerer, by the missionaries, they were not at all aware of the medicinal properties of the plant; their object in planting the tree being, to obtain the seeds to mix with their dyes, and fix their 
coluurs. Dr. Helfer says: "The country produces, spontaneously growing, the ricinus or castor-oil plant," but this is quite erroneous.

Ricinus communis.

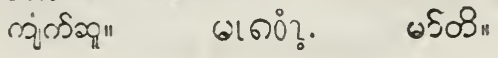

\section{CROTON-OIL.}

The croton-oil plant is frequently seen under culture, and the seeds are administered by native doctors. When the operation is excessive, they give the patient the juice of the sour lime, which is said to counteract the effect of the croton seeds. All the plants that I have examined belong to the exotic species.

Croton Tiglium.

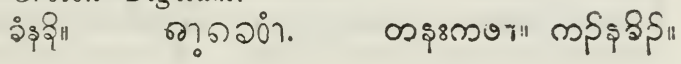

AVA CRUTON.

Lindley says that there is an indigenous, and allied species to the preceding at $A v a$, which is decandrous, while $C$. Tiglium has fifteen stamens.

Croton Pavana.

MANT-STAMENED CROTON.

The Burmese cultivate another species of croton, which grows into a thick bush, and whose seeds are also a strong purgative.

Croton polyandra.

जิริกी॥

\section{WILD CROTON.}

A species of croton, whose roots are used by the natives for a cathartic. abounds in some parts, especially on the Maulmain hills. This species is not described in Roxburgh.

$$
\begin{aligned}
& \text { Crolon. }
\end{aligned}
$$

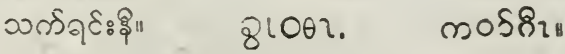

IANGOON CROTON.

The natives describe another species of croton, common in the neighborhood of Rangoon, and occasionally found 
in the Provinces, which is a shrub, three or four feet higli, with properties similar to the preceding.

Croton. os

WOOD-OIL COPAIVA.

Wood-oil is one of the most valuable products of the Tenasserim Provinces; and the tree which produces the best quality is one of the most widely diffused of our furest trees. It yields too, very abundantly. Dr. Helfer wrote, that one trunk would produce thirty or forty gallous each season without injury to the tree. In the reports of the Agricultural and Horticultural Societies of India, it is said : "The wood-oil, properly speaking, is a balsam, obtained from several species of dipterocarpus common in many parts of India. By distillation this bal. sam yields rolatile oil, a resin being left behind. This $0: 1$, Dr. O'Sliauglınessy found to be identical in chemical composition with that of the balsam of copaiva, and he had accordingly used it extensively in his hospital, with exactly the same medicinal effects." " Nor is this article," continues tiie report, "likely to become of impor. tance in medicine only; but also in the arts, in maryy of which copaiva is now used. Copaira, by the latest "dry price current,' was at five shillings and six pence the pound, while twenty pounds of the essential oil of woort may be obtained, of the rery best quality, for about ter. shilliugs."

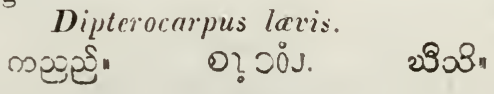

NEEM TREE.

This tree Linnaus placed in the same genus as the pride of India, which it much resembles, but the leaves are more intensely bitter. It is cultivated by the Burmese for its medicinal qualities, for which it is famour a!! over India. The bark has been successfully used in India as a substitute for cinchona; the bitter oil of the fruit is a valuable anthelmintic; the seeds are used in the destruction of insects; and "the leaves," remarks Dr. 
Wight, " beaten into a pulp, and thus externally applied, act as a charm in renioving the most intractable forms of psora, and other pustula eruptions.

Azadirachta indica.

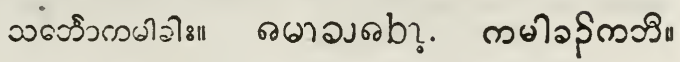

PENTAPTERA-BARK.

A very bitter bark is sold in market, which the natives eat with their betel. I have never seen the tree, but the fruit of it which was brought me, proved it to belong to Roxburgh's genus pentaptera.

Terminalia.

Pentaptera.

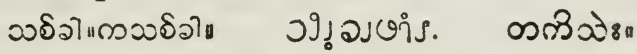

\section{CHIRATA.}

'This well known Indian bitter is a common Burman medicine, but I have never seen the plant growing. It is considered a good substitute for cinchona, but it frequently acts as an aperient as well as a tonic. It is often confounded with another bitter, kreet,--Justicia paniculata.

Agathotes Cherayta.
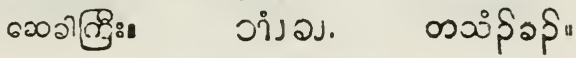

WILLOW.

A species of willow is one of the most abundant forest trees on the banks of inland streams; and as many of the willows are medicinal, it is very probable that this also possesses medicinal properties, but they are as yet unknown. Salix.
§थर०วะ"
ชวกา.
ำวิณี"

SOUTHERNWOOD.

This plant, of the same genus as wormwood, is seen in Luropean gardens.

Artemisia Abrotanum. 


\section{CUTCH.}

Cutch, the produce of a species of acacia, indigenous in Burmah, is an article of merchandise, and large quantities of it are consumed by the natives with their betel. Acacia Calcchu.

$$
\begin{aligned}
& \text { ดว:" } \\
& \text { olsog. } \\
& \text { วำุโ }
\end{aligned}
$$

\section{SEA-COCOANCT.}

'This is not the famous Cocos des mer of the Seychelles, so long the wonder of the world; but a tree very common in the mangrove swamps; and growing near the shore, its fruit falls into the water and floats ont upon the sea, which gives rise to its name. The fruit is not edible, but is exceedingly astringent, and regarderl by the natives as a specific in cholera.

$$
\begin{aligned}
& \text { Xylocarpus Granatum. }
\end{aligned}
$$

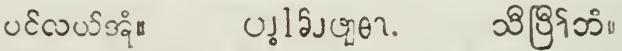

BLACK-PEPPER.

The black pepper wine is often seen creeping "IP the trees, but it is not indigenous.

$$
\begin{aligned}
& \text { Piper nigrum. }
\end{aligned}
$$

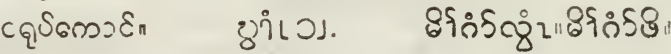

LONG-PEPPER.

Long-pepper is in the bazars, but I have never noticert it growing.

$$
\begin{aligned}
& \text { Piper longum. } \\
& \text { उosa है: }
\end{aligned}
$$

GINGEI,

Ginger is cultivated to a small extent, and some of the Chinese make a ginger preserve of the green roots, in imitation of that which comes from China.

Zingiber officinale.
จर्ट:8ई"
ติ $\varepsilon_{11}$
(Taroy.)
39. 


\section{FENNEL-FLOWER.}

'I'he seeds of this plant, which were formerly used for pepper, are valued by the inhabitants for their carminative properties, but the plant is rarely seen in cultivation. The Hebrew word, which in Isaiah is rendered fitches designates this plant; but not in Ezekiel, where the original word for fitches signifies spelt, a species of wheat.

Nigella sativa.

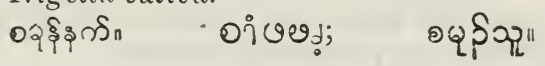

BETEL-LEAF.

The betel-leaf is an article of commerce, being universally chewed by the A siatic population with areca nut and lime, to strengthen the stomach. Karens plant the vines on their uplands, where there are tall forest trees. The branches of the trunks are lopped off, leaving only the topmost boughs, and the vines readily climb up and weave their dark, glossy leaves all over the summits, making a betel-vine farm a most beautiful object. Karen boys and maidens engage in these leaf harvests with great zest, and it is not uncommon for young men, in seeking companions, to inquire who are the most agile climbers of poo-lah, or betel-leaf trees.

Piper Betel.

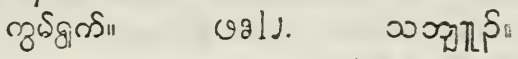

WILD BETEL-LEAF.

The Karen forests produce a wild species of piper, the leaf of which is used as a substitute for the common betcl-leaf.

$$
\begin{aligned}
& \text { Pipcr. }
\end{aligned}
$$

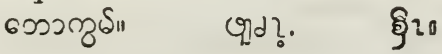

SPILANTHES.

A species of spilanthes is planted by the natives for its medicinal properties.

\section{Spilanthes acmella.}

us:movos 
- CoRIANDER.

Coriander seeds are used as a condiment for curries, as well as for medicine, and the plant is often cultivated by the Burmese.

Coriandrum sativum.

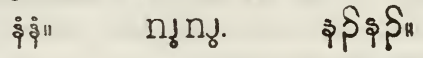

ANISE.

Anise seeds are much used by the native doctors, but I have never seen the plant under culture.

$$
\begin{aligned}
& \text { Pimpinella Anisum. } \\
& \text { ogฐoulu }
\end{aligned}
$$

\section{DILL.}

Dill is occasionally seen, and the seeds are constantly for sale in the bazars. 'This plant is the aneethon of Dioscorides; and Mathew's gospel, rendered in the received version anise. 'The Burnese do not distinguish it from carraway.

$$
\begin{gathered}
\text { Anethum graveolens. } \\
\text { ogos" OQ2S. } \\
\text { sowa. }
\end{gathered}
$$

This is an East Indian species of anethum, possessing similar aromatic, and carminative properties to the preceding. It is often planted by the Burmese.

Anethum Sowa.

of̧os"

\section{CUMIN.}

Cumin seeds are a common article in the inarkets, and the plant, I am told, is occasionally cultivated.
Cuminum Cyminum.

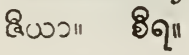
(Sanscrit.)
อำยา. อำเ"
CARDAMUM.

The Karen forests of 'Tavoy, and Mergui abound with cardamum plants; and while subject to the Burmese Government, the Karens were required to collect the seeds and pay them in as tribute; but they gather very few now. 
as they can employ their time more profitably; and when they did collect, they were in the practice of mixing a spurious kind of cardamum with the true, the produce of a plant belonging to the genus amomum, believed to have been $\boldsymbol{A}$. Cardamomum.

Elettaria Cardamomum.

Alpinia Cardamomum.

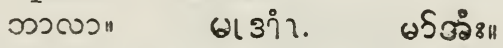

SWEE'T CANE.

- The sweet cane, or sweet flag, is cultivated by the Burmese to a small extent for its medicinal properties, which some writers say are not duly appreciated. This is the sweet cane of the Scriptures, and not sugar-cane, as some have supposed.

Acorus Calamus.

c)E6cว"

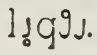

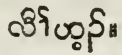

SASSAFRAS.

A species of sassafras abounds in the jungles, which seems to possess all the properties of the sassafras of America. I have never met with the tree in fruit or flower, but the leaf shows that it is not the Sassafras afficinarum. Sassafras.

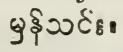

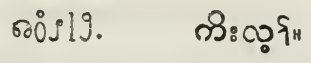

MINT.

Mint is sometimes cultivated by Europeans, but it does not flourish so well as in Eurone.

Mentha viridis.

WILD MINT.

There is a species of wild mint in Tavny, of which Roxburgh wrote: "This plant is very fragrant, not less so than our garden mint in Europe."

Dysophylla quadrifolia.
Mcntha "

บह8\$8 :

8 काกร:

cerbas. 


\section{GALANGA K.EMPFERA.}

The roots of this plant may be often seen attached to the necklaces of Karen females, for the sake of their perfume. 'They also put them with their clothes, and use them to a small extent medicinally.

Kampfora Galanga.

วश्ठउ०

Gd?.

की

KHUSKHUS-GRASS.

Both Karens and Burmese cultivate little bunches of a large grass belonging to the genus andropogon, for its fragrant roots.

Andropogon muricatus.

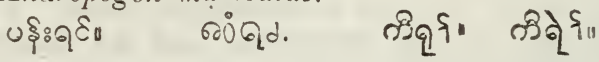

SWEE'T BASIL.

Common sweet basil is not rare in gardens, but I have not met with it indigenous.

\section{Ocimum Basilicum.}

\section{I.EMON-GRASS.}

Lemon-grass is cultivated by the natives all over the Provinces, and a decoction made from the leaves is deemed by them of much efficacy in cholic, and similar complaints

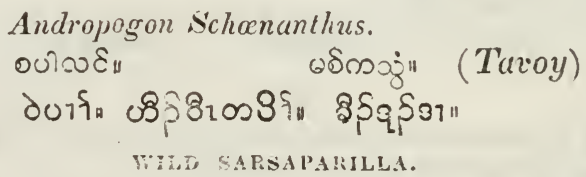

There are two or more specie $z$ of smilax in our jungles, one of which is tiand by the rlives as medicine, to supply the place of a pecies sarsaparilla, whose dried roots are sold in the bazirs.

Smilax ovalifolia.

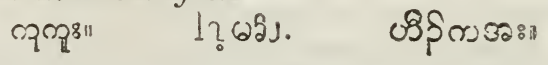

GINSENG.

The Chinese shops have the famous ginseng always on hand, but the plant is not cultivated.

$P$ anax quinquefolia. 


\section{LIQUORICE.}

Dried liquorice is found among native drugs, but I have never seen the plant growing.

\section{Glycyrrhiza glabra.}

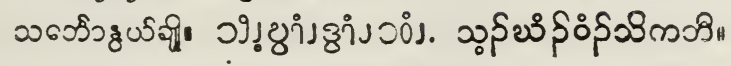
WILD LIQUORICE.

There is an indigenous plant in the forests, the bark of whose roots have the taste of liquorice, but it does not belong to the same genus, though often supposed to be the same tree. I have not seen the flower, but the leaf and fruit would indicate it to be a species of acacia.

Acacia.

$$
\begin{aligned}
& \text { ฉृर्डची } \\
& \text { วงเชาำ ชำงวำ. }
\end{aligned}
$$

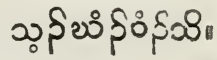

HEART-SERD.

The heart-seed, which has an aperient root, is raised in great quantities by the natives, but more as a vegetable than a medicine.

Cardiospermum Halicacabum.

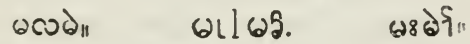

G A RLIC.

Garlic bulbs are always for sale, but they are imported principally from Rangoon. The natives use them both for food and medicine.

Allium sativum.

ఇ.

วมา จ๐่งวง ชุ.

02570 เ

GUM-ARABIC.

The true gum-arabic tree is not in the Provinces, but the vachellia-tree produces a gum with all the properties of the gum-arabic of commerce; and the cashew-tree, which grows all over the Provinces, "annually exudes," says Voigt, "from 5-12 pounds weight, of a fine white transparent gum, like gum-arabic, and not inferior to it in virtue or quality." 
POLANISIA.

The leaves of a very common weed belonging to the genus polanisia, when bruised, are said to act as a sinapism. Polanisia icosandra.

HELICTERES.

The dried, twisted fruit of a species of helicteres is seen among the native drugs in bazar, and is used by Burmese doctors.

Isora corylifolia.

Helicteres Isora. oncof $\operatorname{conn}$

DESMODIUM.

The root of a species of desmodium is valued for its medicinal properties.

Desmodium triquetrum.

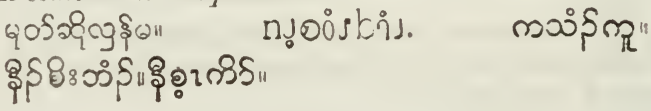

PARATROPIA.

The Karens make an infusion of the leaves of a species of paratropia, a plant of the ivy family, which they use for many internal diseases.

Paratropia digitata.

Paratropia venulosa.

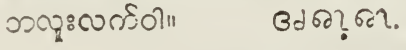

กตุ?

ENTADA.

This magrificent creeper is occasionally seen lending its light rercluie to lofty forest trees, and throwing down immense pods, often more than a yard long. These pods are filled with numerous large dark brown seeds, from one to two inches in diameter.

Though not in Iindley, yet the seeds of this plant enter into the natirc Materia Medica as an anti-febrifuge.

Entada Pusatha.

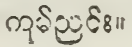

b9? 6052 .

हेते: 
A GXNEIA.

The roots of this curious flowered plant are used medicinally by the Karens.

\section{Agyneia coccinea.}

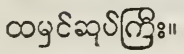

unว $29 \mathrm{Ls}$.

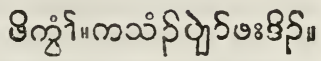

LEEA.

A curious looking herbaceous plant, with a leaf larger than a cabbage leaf, is sometimes cultivated for the astringent properties of its roots. It is the large-leaved leea. The Burmans use it to stop the effusion of blood in wounds; but in Hindustan it is said to be a remedy for the Guinea-worm.

Leca macrophylla.

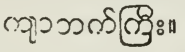

จุรดำริขอริดุน"

TABASHEER.

Some of our banboos secrete a silicious substance called tabasheer, which has a place among native medicinal substances.

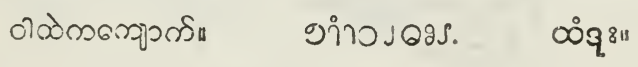

\section{OFFICINAL POTHOS.}

This creeper, as I judge, is not uncommon on the forest trees, but I have never seen the plant in flower. This also enters into the native Materia Medica, but it is not used in European practice, although it has a place in Lindley's Flora Medica.

Scindapsus officinalis.

Pothos

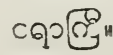

จ mฌి

\section{CYNOMORIUM.}

Dr. Wallich says there is a species of this fungus-like genus, which is parasitical on the roots of trees in the Provinces, and valuable as a styptic; but I have not observed it.

Cynomorium. 
SESAMUM.

'The sesamum plant is largely cultivated by the Karens, who bring the seeds to market and sell them to the Burmese, and they express the oil. 'The seeds are said to have the same property as linseed, and the oil to be a good substitute for olive oil. The natives use it in curries, and also burn it for lights.

Sesamum indicum.
केई।
จง.อ.
\$

OLIVE.

Wallich found at species of olive tree on the banks of the Salwen, but from which no oil is made, that he called Olea attenuata.

\section{KARUNG.}

According to Wallich, the karung oil tree is indigenous in Amherst Province. The Burmese make an oi? from a tree with which I have never met, that may be the tree referred to by Wallich.

Pongamia glabra.

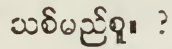

COUNTIY MILLOW-LEAF.

The Burmese raise a species of abutilon, which is considered all over India a very good substitute for marshmallows.

Abutilon indicum.

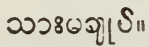

SESBANIA.

A species of seshania may be seen in culture for the sake of its leaves, which the Burmese use for poultices to promote suppuration. Owing to this characteristic they call the tree "water-chief.

Sesbania agyptiaca.

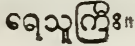




\section{SUGAR=CANE.}

That these Provinces are well adapted for the cultivation of sugar-cane, has been well tested by $\mathrm{Nir}$. O'Riley, who made many tons of very excellent sugar from cane that was raised at $\Lambda$ mherst. In Hindustan the micilage of the musk-mallow, Abelmeschus moschatus is used to clarify sugar, and it is one of our most common indigenous plants: Both the Burmese and Karens grow sugar-cane, which they chew for its juice, and from which they make cake. sugar.

Saccharum officinartem.

กำ ऊำงอㄴ.

œ3ริ่n

\section{NIPA.}

The nipa is very extensively cultivated in the province of Tavoy. From incisions in the stem of the fruit, toddy is extracted, which has very much the flavour of mead, and this extract when boiled down becomes sugar. In Burmah, where the palmyra abounds, an extract from that tree is made to supply its place.

\section{Nipa fruticans.}

$$
\text { ว\$ี ชทาง. }
$$

$$
\text { ஸฐి811 }
$$

COFFEE.

Coffee not inferior to the best from Mocha, I have raised in my own garden at Tavoy, but the plants do not flourish after the fourth or fifth year.

Coffea arabica.

\section{MERGUI SAGO.}

Sago may be seen in every bazar in the Provinces, but it is not generally known what plant produces it, many having the erroneous impression that it is made from manihot. It is the produce of an indigenous plant abounding along the sea shore,the islands, and especially at Mergui - a species of tacca, the same plant that is common in the South Sea Islands, whose tubers there supply to the inha. bitants the place of bread. Considerable quantities of 
sago are made at Mergui, yet Lindley in his Medical Bo. tany, makes no reference to tacca as yielding sago.

Tacca pinnatifida.

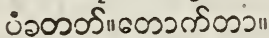

ววฉ" common sa.go.

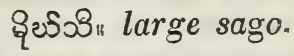

\section{MERGUI ARROW ROOT.}

A spurious kind of arrow root has long been made at Mergui from the same plant as that which yields the sago. But medical men have decided that it contains properties which render it unsuitable for the sick, and chemical anaJysis has developed that it contains only half the nutritious qualities of the genuine arrow root.

\section{TRUE ARROW ROO'T}

The true arrow root plant was introduced sereral years ago by Mr. O'Riley, and is beginning to be largely culti$\checkmark$ ated. 'The arrow root made is not inferior in quality to any imported; while it is sold for half the price, at a good profit. A gentleman at Tavoy has sold a considerable quantity for exportation this year, and has orders for more than a thousand pounds of the next crop.

Maranta arundinacea.
ט $8 \%: "$
ujษา.
o $\left\{8^{\uparrow_{i i}}\right.$

TAPIOCA TREE.

1 am not aware that either tapioca, or cassava is manu. factured on this Coast, but manihot, the plant which produces both, is frequently seen in culture. The natives boil the root, and eat it like a yam, though severe sickness is cften induced by the use of it. The Karen name signifies "tree yam," and in Burmese it is called the "Penang yam," which shows whence it was imported. Malays hare told me that much of the sago, and arrow root which comes from Penang and Singapore, is made from this plant, though the former is usually supposed to be prepared from the sago palm; and Mr. Ranney informs me that arrow root is made from it at the Mauritius. It is saic that an acre of ground, planted with the cassavatree 
yields nourishment to more persons than six acres cultivated with wheat.
Janipha Manihot.
Jatropha

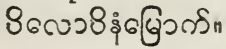
ถรงวยุ.

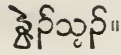

EDIBLE MOSS.

This is a sea weed, abundant on the Coast, and exceedingly valuable for its nutritious and medicinal properties for invalids. It was first brought to public notice by Dr. O'Shaughnessy, as "The eaible moss of the Eastern Archipelago," who referred it to the genus fucus. The fructifications, however, being in small tubercles, I should consider it a species of Agardh's gellus, sphrerococcus; but that genus having been broken up, it now constitutes a member of the genus plocaria. It is an allied species with the Ceylon moss, $P$. lichenoides, with a species found on the coast of Devonshire in England, $P$. compressa; with the Corsican moss of the Mediterranean, $P$. Helminthochorton; and with a species used in China as a substitute for glue and gum-arabic, $P$. tenax; but differs generically from the Irish, or Carrageen moss, Chondrus crispus; and is not of the same natural family with the Iceland moss, Cetraria islandica, which is neither a moss nor a sea weed, but a lichen.

The Tenasserim moss is said to be superior to all others, as it is wholly free from the bitter principle, which renders other fuci so objectionahle. It contains a considerable proportion of starch, and was hence named by Dr. O'Shaughnessy, the starch fucus, $\boldsymbol{F}$. amylace specific name has since been changed to candida, white, probably from a mistaken idea that the substance is naturally white, whereas it becomes so only by bleaching in the sun; its natural tint being a shade between olive and purple, such as the natives designate red.

According to Dr. O'Shaughnessy's analysis it contains as follows :

- Vegetable jelly, ... $\quad \ldots \quad \ldots \quad \ldots \quad 54.5$

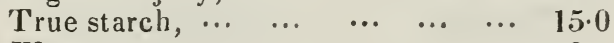

Wax, a trace, $\quad \ldots \quad \ldots \quad \ldots \quad \ldots \quad 0.5$ ? 


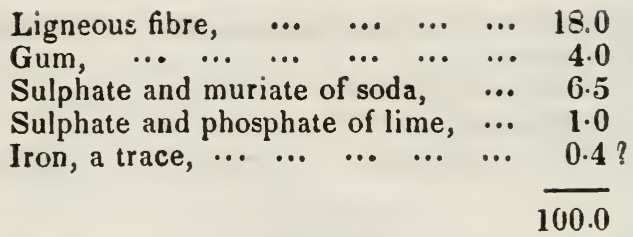

On the best mode of preparing it for use he adds :

"In the first place, from the tendency of pectin or vegetable jelly to form insoluble compounds with saline and earthy bases, it is necessary to steep this fucus for a few hours in cold rain water as the first step in its preparation. This removes a large portion, if not the entire, of the sulphate of soda, leaving all the gelatine, and starch. It should next be dried by the sun's rays, and ground to a fine powder; I say ground, for cutting or pounding, however diligently or minutely performed, still leaves the amylaceous globules so mechanically protected, and so closely involved in an external sheath of tough ligneous fibre, that scarcely a particle of the starch can be extracted by boiling, eren though the decoction is prolonged for several hours. When ground, boiling for $\mathbf{2 5}$ minutes or half an hour dissolves all the starch and gelatine. The solution while hot should be passed through muslin or calico, and thus the ligneous fibre is remored ; lastly, the strained fluid should be boiled down till a drop placed on a cold surface gelatinizes suf. ficiently.

"With milk and sugar, and flavoured with lemon juice or sherry, this substance, when prepared as I direct, would afford the invalid a pleasant article of diet, especially at sea, where other jellies or their materials cannot be so easily preserved. As I am informed that this fucus is found abundantly on the eastern coast of Bengal, I entertain considerable hopes of its being hereafter found available alsu in several processes of art and in various manufactures."

Plocaria candida.

Fucus amylaccus.

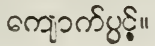




\section{PLANTS PERTaining to economics.}

There are numerous plants used for dyes, for tanning, for clothing, for cordage, for building, and for other economic purposes, which admit of being grouped together.

VARIOUS BLACK-DYE PLANTS.

The blossoms of the shoe-flower plant are used by the Chinese to dye leather black, the juice of the cashew-tre e gives a black to linen, and the fruit of the melastoma affords a black dye.

\section{SHAN BLACK DYE.}

This celebrated vegetable dye is made from the fruit of a species of ebony, which is said to grow on the mountains that separate the Province of Tavoy from the Siamese territories. Isolated plants may be seen in the gardens of Tavoy, and Maulmain, but I have never seen one in flower, or fruit.

$$
\begin{aligned}
& \text { Diospyros mollis. }
\end{aligned}
$$

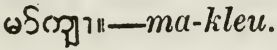

$$
\begin{aligned}
& \text { (Sgau.) }
\end{aligned}
$$

CHEBULA.

The fruit of the chebula mixed with an iron clay is in common use to form a black dye, which is said to be very good. All the native ink is made from this fruit, but although black when used, in the course of a dozen years it sometimes fades so that the writing is scarcely legible. The tree is found throughout the Provinces, but is not very abindant.

Terminalia Chebula.

$$
\begin{aligned}
& \text { लฉห" } \\
& \text { uq" (Tavoy.) }
\end{aligned}
$$

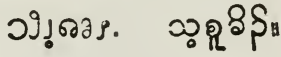

PHYSIC-NUT.

'The physic-nut tree is often seen in cultivation, and its juice dyes linen black. Lindley says : "The oil boiled with oxide of iron forms a varnish used by the Chinese for covering boxes." The Hindus use the oil to burn in lamps.

$$
\begin{aligned}
& \text { Jatropha Curcas. }
\end{aligned}
$$

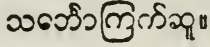




\section{MARKING NUT.}

'This fruit produces an indelible ink which is used for marking, and for other purposes. The dried nuts are constantly for sale, but I have never met with the tree growing.

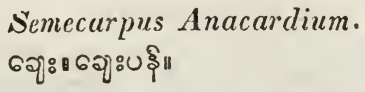

OAK GALLS.

Oak galls can always be obtained of the native druggists, but I think they are all imported, although we have several species of oak indigenous in the Provinces.

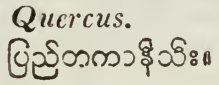

RUELLIA.

The Burmese cultivate a low plant as a substitute for indigo which is the room of Assam, from which country it has probably been introduced. It forms a blue dye not inferior to ihat produced by the true indigo plant.

Rucllia indigofera.

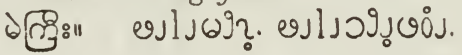

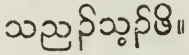

\section{ASCLEPIAS BLUE DYE.}

The Karens, and sometimes the Burmese, plant a creeper that is indigenous in some sections, and which makes quite a good indigo blue, though not equal to the ruellia dye.

\section{Marsdenia tinctoria. \\ Asclepias

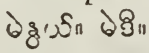

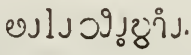

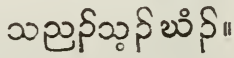

INDIGO.

The true indigo plant is grown occasionally by both $\mathrm{Ka}$ rens and Burmese, but less extensively than either of the preceding.

Indigofera linctoria.

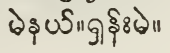

ชวด0ำ. 
WILD INDIGO.

An indigenous shrub, a species of indigo, is sometimes used in forming a blue dye.

$$
\begin{aligned}
& \text { Indigofera. } \\
& \text { ६ेवृहः" } \\
& \text { Qร०ง?. } \\
& \text { ఫ้ขึิดำ }
\end{aligned}
$$

JAMBO MORDANT.

The bark of a species of eugenia is used as a mordant for blue and black dyes.

Eugenia Jambolana?

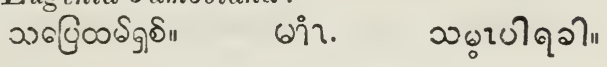

\section{VAR:OUS RED-DYE PLANTS.}

The rose-coloured fruit of the tamarind "yields a beautiful deep red-colour, approaching purple"; the wood of the Adenanthera pavonia dyes red, and the wood of the black varnish tree affords a red dye.

\section{SAPPAN WOOD.}

Ii the valley of the Tenasserim, between the latitudes of Tavoy city and the mouth of Taroy river, the hills that border the valley on the eastern side abound in sappan wood, which is used extensively as a red dye. Considerable quantities are exported every year from Hergui, and that province is usually supposed to contain the tree, though it is really within the province of 'Tavoy; but the facility of water communication from the interior to Mergui, makes that the only port to which the wood is conveyed. It is rather singular that this narrow locality is the only one in the Provinces, so far as I am aware, in which the tree is found. The tree has a much wider range, the Karens inform me, on the Meinam side of the mountains in Siam. More than fire hundred thousand pounds have beell exported from Miergui during some years between 1830 and 1840 ; but latterly the forests have not been so productive.

Cosalpinia Sappan. 
LOG-WOOD.

The log-wood tree is cultivated in a few gardens, and appears to flourish as well as an indigenous plant.

Hamatoxylon campechianum.

ARNOTTO.

The arnotto tree, though an American plant, is propagated extensively by the Burmese, who prepare a red dye from its fruit.

Bixa Orellana.

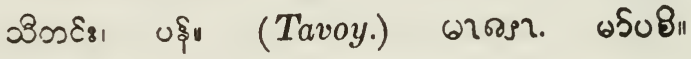

MORINDA.

The Karens prepare their red dyes most usually from the roots of the morinda tree, of which at least two or three species are used for this purpose. One, $\boldsymbol{M}$. citrifolicl, is also cultirated by the Burmese for a dye, but the $\mathrm{K}$ arens more commonly use the indigenous species.

Morinda citrifolia.

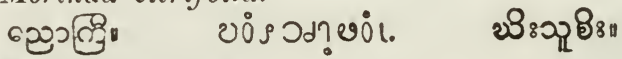

Morinda exserta.

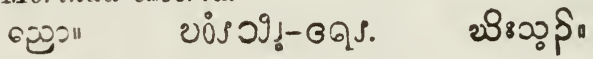

Morinda.

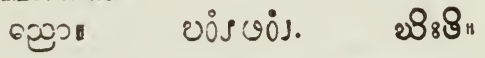

INDIAN MADDER.

Indian madder, though not seen in the Provinces, is found in Burmah.

Rubia cordifolia.

MANGROVE MORDANT.

The bark of a small tree from the mangrove swamps is used by the Tavoy women in dying red, but I think as a mordant.

Kandelia Rhcedii?

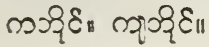




\section{VARIOUS YELLOW-DYE PLANTS.}

The wood of the jack, the root of the pyschotria, the bark of the gamboge trees, the flowers of the buteas, the rind of the Bengal quince, and the leaves of the inemecylon and the touk-yat, all produce bright yellow dyes.

\section{SAFFLOWER.}

The safflower is widely grown on the banks (f ine Irrawaddy, and may be occasionally seen on the banks of the Salwen. Its flowers furnish the best yellow dye in the country, and mixed with other ingredients they are used to dye red, and to give a variety of tints.

\section{Carthamus tinctorius.}

$$
\text { ac: }
$$

\section{TURMRRIC.}

Besides using turmeric for both food and medicine, the Burmese and Karens dye wht it a bright yellow. but it is not very permanent.

\section{Curcuma longa.

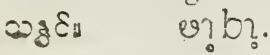

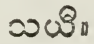

VARIOUS ORANGE-DYE PLANTS.

The flowers of the buteas with an alkali, the corolla tubes of the tree of mourning, and the leaves of the henna tree, yield beaitiful orange dyes. "The latter are used in India to dye skins a "reddrsh-yellow."

\section{MERGUI RED-WOOD.}

Mergui red-wood is a valuable dye wood for both black and red, but more especially for oranges From an article in the Journal of the Asiatic Society, it appears that " a number of experiments, made at the request of $\mathrm{Mr}$. G. Swinton, by Mr. Thomas Speir, upon the Niergui dye wood, prove that it affels, with the mordants commonly used by dyers, c equally bright, and of a more permanent nature thin cinse of most other dye woods. The colove imparted to silk with different mordants were as follow: 
1.- Muriate of tin. Three shades of orange, varying with the temperature of the bath, and the time of immersion.

2.-Acctate of alumina. 'T'wo shades of fiame colour.

3.-Acctate of iron. 'Two shades of drab.

4.-Ditto, with a weak decoction of galls. A fine black, two shades.

5.- Hixed with manjit, a variety of red and pinks are obtained, but not perhaps equal in intensity to those of the manjit alone. The clief attraction of this wood as a dye, is the orange colour which it yields with the aid of muriate of tin and acetate of alumina, of a great variety of shades.

These results shew that the Mergui wood is deserving of further attention, and that it may become eventually an important article of commerce with our possessions on the "Tenasserim Coast."

It is not quite certain what tree produces the Mergui red-wood. 'The flowers which accompanied the specimens of the wood sent to Calcutta, belonged to the Burman black varnish tree, yet Mr. Maingay who sent them, thought it a different tree. I imagine tliere was some mistake, and that the Mergui red-Wood is identical with the Taroy red-wood.

\section{Syndesmis 'Taviyana.}

GREEN-DYE PLANTS.

Turmeric, and the leaves of the soap-acacia afford a Leantiful green dye.

Acacia rugata.

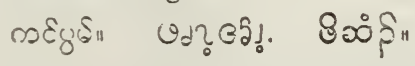

\section{BLACI VARNISH TREE.}

The celebrated Burmese black varnish tree, which is uste to lasquer boxes, is cultirated in the Provinces, but I never saw it growing spontaneously.

Melanorrka usitatissima.
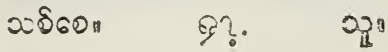


\section{WILD BLACK VARNISH TREE.}

There are two indigenous species of the same genus that produces the common black varnish; but I am not aware that the exudation which they yield is applied to any economical purpose.

$$
\begin{aligned}
& \text { Mclanorrhoa glabra. } \\
& \text { "visitata. }
\end{aligned}
$$

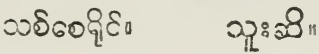

$$
\begin{aligned}
& \text { HOLIGARA. }
\end{aligned}
$$

There is another black varnish tree in the forests, belonging to a different genus; and on the other Coast, where the tree grows, its exudation is used by the natices to varnish shields, and for other purposes.

$$
\begin{aligned}
& \text { Holigarna longifolia. } \\
& \text { दु) } 6 \text { वु: ? }
\end{aligned}
$$

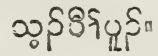

YELLOW VARIISH TREE.

A species of garcinia that has often been mistaken for the tree which produces gamboge, is rery abundant throughout the Provinces, and the gum-resin which it yields when dissolved in spirits of turpentine, affords a beautiful permanent yellow varnish for metallic surfaces.

Garcinia Cambogia.

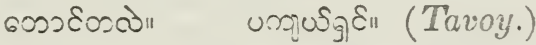

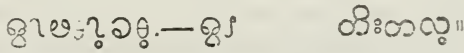

PINEY VARNISII TREE.

Trees which yield this beautiful varnish so extensirely used in Hindustan, are very common about Maulmain, yet I am not aware that the rarnish is collected.

Vuteria Roxburghiana.

$\cos 6000 \sin _{n}$

TANNIN TREES.

The Provinces are rich in materials for tanning. The bark of the Careya, and of half a dozen different species 
of mangrove, the fruit of the sea-cocoanut, and the peel of a species of ebony, all abound in tannic acid.

Rhizophora conjugata.
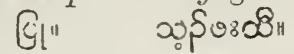

Rhizophora gymnorhiza.

Bruguierc Rhccolii.
" criopcíala.
"priviflora.

El"?
Carallia lucida. 6olहs

Íandelia Rhecdii.

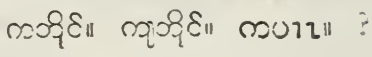

COCOANET.

'The Burmese express large quantities of cocoanut oil, but use it principally to burn.

cocos nucifera.

sqर्ध $q$ iा

23ิน"

CERBERA.

In many places on the banks of tide-water streams, the most remarkable tree in sight is a species of cerbera, whose fruit is used very extensively by the Burmese to make an oil which they burn in their lamps, and use to anoint their heads; a use not mentioned in the books. Lindley describes it as emetic and poisonous, of which there can be no doubt. " "The milky sap," he continues, "is employed as a purgative. 'The leaves and bark are so similar to senna in their action that they are substituted for it in Java." 'These are properties which are unknown liere, and their existence may be doubted. If the statement be correct, these Provinces might supply all India with senna; for the tree abounds from the mangrove swamps on the seashore, to the boundaries of tide-water on almost eyery stream, and any quantity of leaves may be obtained for the trouble of gathering.

$$
\begin{aligned}
& \text { Cerbera Manghas. } \\
& \text { m清 } \\
& \text { วิง ว0ْง. }
\end{aligned}
$$

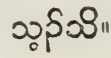

WOOD OIL TÁEE.

Dr. Helfer says that the oil of wood "laid upon paintings covers them with a transparent fine coating, not liable to turn yellow, and dries quickly." 
A few years ago Mr. Laidlay, the Secretary of the Asiatic Society, discovered that the oil of wood will dis. solve caoutchouc. "The process adopted was simply to cut the caoutchouc into small pieces, and then drop a sufficiency into a bottle of the oil. In the course of a few hours the caoutchouc swells, and mist then be fre. quently stirred to facilitate the process. If heat be applied, complete solution is speedily effected, but several dajs are required at the ordinary temperature of the atmosphere. The solution thus prepared may be spread on cloth, which is thereby rendered water-proof." Wood oil has been found to answer as a good substitute for fish oil in currying leather; and it is used for house varnish.

Large quantities of this oil are used in these Provinces in the manufacture of torches, which emit a brilliant and durable light. A half dozen of these torches planted on an eminence make a splendid cresset, illuminating far. over the plains.

$$
\begin{aligned}
& \text { Dipterncarpus lavis } \\
& \text { turbinatus. }
\end{aligned}
$$

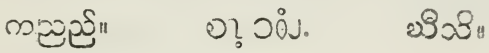

OII. OF BEN TREE.

The tree which yields the celebrated oil of ben is very abundant, though I am not aware that any oil is pressed from the seeds in these Provinces. But in the West Indies the oil of this tree is used for salad oil, and "because it does not congeal or turn rancid, employed by watchmakers, and for retaining the aroma of delicate flowers."

Moringa ptcrygosperma.

Hyperanthera Mloringa.

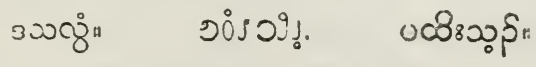

ILLIEPIE OIL TREE.

In the southern part of the Provinces a large timber tree is indigenous, from the seeds of which the natives $\in \mathrm{X}$ press an oil which they eat with their food, and use for other purposes. It is a species of bassia, and does not 
differ sufficiently from the tree which produces the it liepie oil of Hindustan to constitute a new species.

Bassia longifolia.

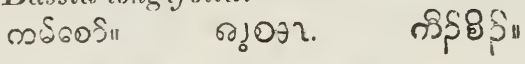

CAOUTCHOUC.

Within a dozen years the true caoutchouc tree of $\Lambda$ ssam has been introduced into the Provinces, and appears to grow as well as an indigenous plant.

Ficus clastica.

\section{TENASSERIM CAOUTCHOIC.}

An indigenous creeper yields caoutchouc not at all incrior to that which is obtained from the elastic fig tree. The Agricultural and Horticuliural Society, in reporting on a specimen sent them by Major Macfurquhar of 'Tavoy, observed: "With care in preparing, it would be equal to the best South American." I have never seen the plant in flower, but to judge from the fruit, it belougs to the dogbane tribe, and echites group, for its seeds are comose abozc.

Echites.

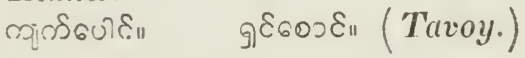

$$
\begin{aligned}
& \text { (99). चेे॥ }
\end{aligned}
$$

DAMMER.

Dammer in India supplies the place of pitch and rosin, and in these Provinces is the product of three differen: genera belonging to the wood oil tree family-the sho= rea, the hopea, and the dipterocarpus.

$$
\text { SOAP-NUT. }
$$

The soap-nut tree has been introduced, and appears to flourish.

Sapindus cmargin!tus.

$$
\text { SOAP ACACIA. }
$$

The dry pods of a species of acacia are sold in the bazars, which are used as a substitu fe for soap in cleansing the hair.

Acacia rugata.

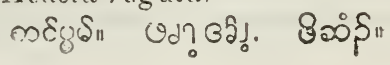


FLAX.

The flax-plant is not, so far as I know, cultivated either in these Provinces or Burmah, but the Burmese are acquainted with linen from their books in which it is frequently mentioned.

'The lake or tank near king Wathandria's hermitage, is described as being covered with water lilies, that anpear like garments made of thread of flax bark ; and linen garments are mentioned among those which priests are per. mitted to wear.

Linum usitatissimum.

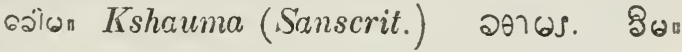

\section{NATIVE COTTON.}

The Karens usually grow cotton enough to make their own fabrics, and on the Salwen and Tenasserim it is sometimes raised in considerable quantities; but its market price is little more than a fourth of the best American cotton ; yet with improved modes of culture, and frequent changes of seed, its value would undoubtedly be great'y increased.

\section{Gossypium heruaccum. อी॥ bวิา. ગे॥}

PERNAMBCO COTTON.

Mr. Blundell introduced the plant which produces the Pernambuco, Peruvian, Bahia, or South Sea lsland cotton; and Capt. Macfarquhar raised such a fine artic!e at 'Tavoy from it, that the Committee of the Agricultural and Horticultural Society of Calcutta were unwilling to believe it the production of that species. They reported: "The sample sent by Capt. Macfurquhar appears to be of a quality resembling the Sua Island, but finer and more silky, and the fibre not so strong, its value is not so easy to determine, but the Committee are of opinion that it would sell for a high price. The Pernambuco cotton, which it is believed, is the same as the South Sea Island cotton, is an inferior staple to that of the N. American Sea Island, and they have a sample of cotton submitted, 
which in point of fincness surpasses the genuine Sea Iso land cotton of $\mathrm{N}$. America.

"This improvemr nt on the general staple of Pernambuco cotton might be reconciled had it been produced at a distancc firom the sea, sunce it has been ascertained, that this description of cotton deteriorates by proximity to the sea; whence your Committee are disposed to think that Captain Macfarquhar has been led into errour in calling it South sca Island instead of Sea Island."

Admitting that Captain Macfarquhar was in errour, which it is believed he was not, the report proves that an article "finer and more silky," than the best American cotton has becn raised in these Provinces. The principal difficulty to the introduction of this species into general cultivation was, as Mr. Blundell told me, that the trees did not produce abundantly.

Gossyrium acuminatum.

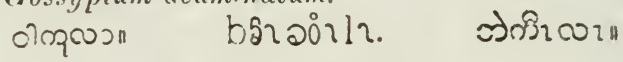

SEA ISLAND COTTON.

Sea Island cotton has been raised in these Provinces by amateur cultirators, but I have never seen any report. on the article obtained. "Bourbon cotton of Indian growth," says Wight, "has sold in the London markets for the highest prices going ;" and, as the Bourbon plant is the original Sea Island acclimatized to the East, the cultivator would have a stronger probability of success by obtaining his seed from Bourbon, than from America. Much attention should also be given to the selection of a proper soil. Analysis has shown that all the lands on which cotton is grown in India, differ widely in their constituent parts from the best cotton lands of America. 'The subject is still in its infancy, more extensire analysis being required; "but it seems at present," observes Mr. Piddington, "that the abundance and fineness of good cottons depend on the quantity of carbon in the soil, and the solubility of that carbon. If therefore, you can obtain a soil approaching the American soils, that is, containing peaty matter, lignite, and colouring cold water, this will no doubt be the best; because it contains 
carbon, and probably hydrogen combined with it, suitable for the food of the plant. And the next best soil is one containing carbonate of lime."

Gossypium bribadense.

Var. (a) Barbadoes, or Bourbon cotton.

"(b) Sea Island, or long stapled "

"(c) Upland Georgia, cr short stapled"

HEMP.

Near the Burmese villages large fields of a yellow-flowered plant, as tall as wheat, may be often seen, which is called hemp. In Hindustan it is called Bengal flax. Although the stems of the plant produce a substance analagous to flax or hemp, it bears no relation to those plants, but is $n$ species of crotalaria, a leguminous plant. 'The true hemp though occasionally grown to a small extent, is never fabricated into cloth.

\section{C'rotalaria juncea.}

ن:"

\section{טริำ}

NETTLE IIEMP.

In the neighborhood of Ava a substitute for hemp is diffused, belonging to the genus urtica, which was cultivated for several years by Major Macfarquhar at Tavoy, who endeavoured to induce the natives to foster it, but it has not yet been brought into general culture. Colonel Burney said that the Burmese at Ava called it goun.

Urtica tenacissima.

$8: S_{9}$

SIDA HEMP.

The most troublesome weed in Tavoy produces a very fine hemp or flax. There are two species, but they are not usually distinguished.

Sida acuta.

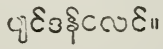

Sida stipulata.

q)

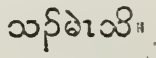

URENA HEMP.

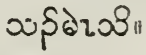

Another weed which abounds all over the Coast serres 
in the place of hemp in Amherst Province, and appears to afford a valuable article.

\section{Urcna lobata.}

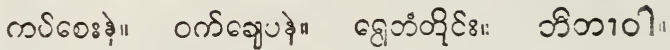

\section{CORUAGE PLANTS.}

As in other parts of India, cordage is made of coir, the nutside shell of the cocoanut, but ropes are more frequently made from the bark of three different trees belonging to the genera hibiscus, paritium, and sterculia.

Paritium macrophyllum.

Hibiscus macrophylius.

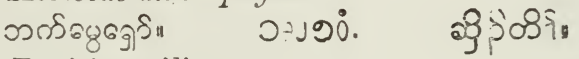

Paritium tiliaccum.

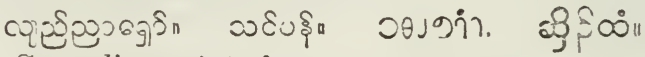

Stcrculia guttatn?

"ornata?

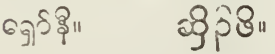

RED COTTON TREE.

The red cotton tree is one of our most abundant forest trees, and the silky down that envelopes the seed is used to stuff mattresses and pillows; and it has occasionally been made into cloth. 'There appear to be two species, but I can refer to the description of one only.

Salmalia molubarica.

Bombax malabaricum.

Salmalia insignis.

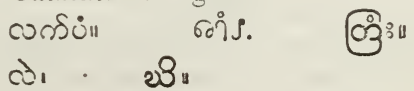

WHITE COTTON TREE.

The white cotton tree does not grow spontaneously, but is often planted, and the floss, which it yields abundantly, is preferred to the product of the red cotton tree.

Gossanipinus Rumphii.

Eriodendron anfractuosum.

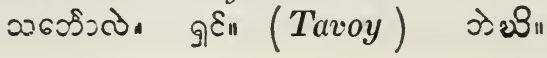


PAPYRUS.

Many of the mats sold in bazar are imported from Calcutta, where they are made of a species of papyrus that grows in Bengal.

Papyrus Pangorci.

Cyperus tegctum.

0.र००ว" 2.5 ग.

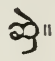

MARANTA.

Some of our mats are made from the split stems of a species of maranta, but they are all imported from Rangoon, although the plant from which they are made, or an allied species, is abundant in our own forests.

IIaranta dichotoma.

Thalia cannaformis.

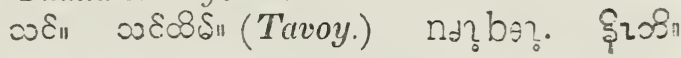

LOWLAND SCREW-PINE.

The large coarse mats in unirersal use are made from the leaf of a species of screw-pine, that grows abundantly on the lowlands near tide-waters.

Pandanus furcatus ?

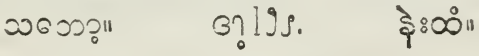

HIGHLAND SCREW-PINE.

Smaller and finer mats in ccmmon use are fabricated from the leaves of another species of screw-pine, that grows on the highlands above tide-waters.

Pandanus.

\section{SAIL-LEAE.}

On many of the Burmese boats, sails are seen made of large narrow leares, sewed together. They are the leaves of a species of screw-pine that has a trunk like a palm, which is very abundant and usually grows near the sea. The fruit is used by the Karens to hackle their thread.

Pandanus.

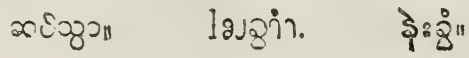




\section{PAPER PLAN'T.}

The Burmese make a coarse paper from the bark of a large creeper that is found in the forests. The paper is as thick as paste board, and the surface is blackened and written-upon with a steatite pencil. I have never seen the plant in flower, but it is probably a species of daphne. Dapine.

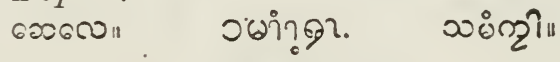

\section{PALM-LEAF.}

All the Burman books are made of the leaf of a species of corypha, but the orders that are issued from the Burmese courts are written on strips of palmyra palm-leaf.

\section{ABRUS.}

The jewellers use the seed of a species of abrus, red, with a black eye, or black with a white eye, for small weights. It is a popular belief that they almost "uniformly weigh exactly one grain, troy;" but I have weighed mary and found them to vary from one to two grains. The Burmese use them within a fraction for two grain weights. One hundred and twenty, by one mode of reckoning, and one hundred and twenty eight by another, make one tickal, which weighs according to Capt. Low 253.75 grains troy.

$$
\begin{aligned}
& \text { Abrus precatorius. }
\end{aligned}
$$

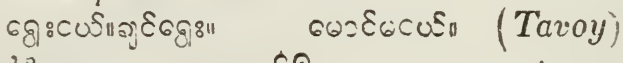

$$
\begin{aligned}
& 13002 \text {. 200. } 88 z
\end{aligned}
$$

\section{ADENANTIERA.}

Another seed which the books represent as usually weighing four grains, is in common use by the Burmese, as equivalent to two of the preceding, which is about four grains. The seeds, however, have to be selected for the purpose; many of them not weighing more than two, or three grains each

$$
\begin{aligned}
& \text { Adenanthera pavonina. } \\
& \text { 6g: तु०ू: }
\end{aligned}
$$

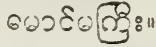

$$
\begin{aligned}
& \text { (Tavoy) } \\
& 19 \cos 0500^{\circ} \text {. } \\
& \text { งอง }
\end{aligned}
$$




\section{BEAD PLANTS.}

The Karens in the southern provinces cultivate one $\mathrm{cr}$ two species of Job's tears for the seed. The Pwos plant a species with round seeds which are used to ornament the borders of their tunics, but they are never seen on a woman's gown. The Sgaus on the contrary, cultivate a species bearing an oval seed, and use them merely for embroidering female dresses. In Amherst Province, the Pwos seldom appear in their native costume, and many deny that their tribe ever had any other than that which they now wear, "hich is Burmese.

Coix.

mos.

$$
\text { ชอ․ }
$$

THATCH LEAF.

In some sections of the country the Karens thatch their houses with large palmated leaves of a tall wild palm, pro. bably a species of livistona; sometimes the leaves of a species of ratan are used; but the Burmese and Europeans almost universally thatch their houses with the leaves of the nipa.

\section{THATCH GRASS.}

The Karens in Amherst Province cover their houses with the tall grasses which are so abundant on the Const, and a few Europeans prefer this thatch to that made from the nipa. Two different species of grass are used for this purpose, both of which were formerly referred to the genus which produces sugar cane.

The sugar grass seen in Maulmain, which flowers two or three feet high, has been removed since Roxburgh wrote, into the genus imperata. This is one of the grasses used for thatch, and is often mistaken for Saccharum spontantum, which is the other.

Impreata cylindrica.

Saccharum cylindiricum.

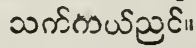

อวำงอำ

ஸ் ชั

Saccharum spontaneum.

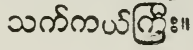

อาำกรั.

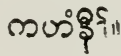




\section{CANE.}

Cane or ratan is used extensively by the natives instead ef cordage. The stays of the masts in native boats are usually made of ratans, and they are split up into strings for innumerable purposes to which cord and twine are usually applied. All that gives stability to bambon houses, is the ratan which ties them together. There are numerous species indigenous in the forest, and the Karens have different names for seventeen species or varieties.

\section{Calamas.}

$$
\text { भीज्या ०ु. की }
$$

вамвоо.

The bamboo is used for all purposes to which timber is nsually applied. Most of the native houses in the Provinces are built principally of bamboos tied together with ratans. Cots, seats, and tables are often formed of the same material. The Karens have names for seventeen species or varioties, one of the strongest of which is corered with large thorns, and makes an impenetrable fence ; but the China bamboo, which has been introduced f: om Penang, makes the closest and prettiest hedge, and when cut annually, looks like an English quick-set hedge. The gigantic bamboo, the largest bamboo in the world, is indigenous, but in the southern provinces is seen only in cultivation.

Bambusu spinosa, (thorny bamboo.)

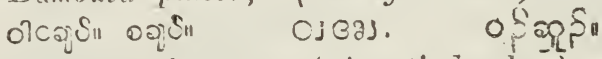
Bambusa gigantea, (gigantic bamboo.)

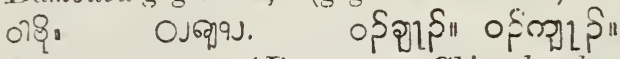
Bambusa nana. (Penang, or China bamboo.)

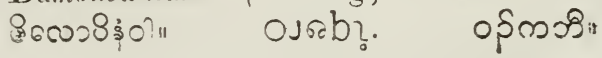




\section{TIMBER TREES,}

The yellow wood of the jack affords beautiful timber for furniture, and in some parts of India it is high. $4 y$ valued. 'The heart of old tamarind trees furnishes a hard, dark-coloured wood, resembling ebony. Roxburgh says the wood is "durable and beautifully reined." Cussia florida has wood "not inferior to ebony." Pongamia glabra, and Wrightia coccinea have light fine wood. The Ceylonese iron wood tree, Adenanthera paronina, Iachellia Farnesiana, Acacia Catechu, and the jujube tree furnish hard, tough wood. Cassia fistula, Cassia nodosa, the chestnut tree, Sandoricum indicum, Nauclca Cadamba, and one or two species of eugenia afford good timber.

These are among more than a hundred trees in the Provinces that furnish valuable woods, of which the following selection of fifty or sixty embraces the most useful.

TEAK.

Teak is the staple timber of the Tenasserim Provinces, and from its abundance in Province Amherst, and its valuable property of being impervious to the white ants, it is used in Maulmain almost exclusively both for building purposes, and for furniture. In 1848 eighteen thousand tons of this timber were exported, and $\mathrm{Mr}$. O'Riley estimated that more than three thousand tons were used for home consumption; the total value of the whole falling little short of a million of rupees.

Tectona grandis.

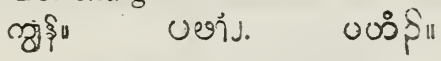

HAMILTON TEAK.

This is an inferior species of teak that grows on the banks of the Irrawaddy ; and from native descriptions, I magine it is found in the province of Yay.

Tectona Hamiltonia. " ternifolia. coscososn osuses: 


\section{BASSIA.}

In the southern Provinces, the bassia tree is quite abundant in a few localities; and it is said to afferd a tim. ber in no way inferior to teak.

Bassia longifolia.

ल660ई:

6ejogr.

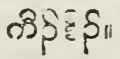

IPON WOOD TILE.

'This is a species of the old genus acacia, and the timber is usually denominated iron wood in Arracan, and is sometimes so called in these Provinces. 'The hard wood is as impervious to white ants as teak, and is even more durable in the ground. Natives have assured me that they have seen house posts of this woot taken up after having stood forty years, and that the part which had been buried was as sound as new timber. The trees abound in the province of Taroy, especially near the forks of the 'Tenasserim.

$$
\begin{aligned}
& \text { Inga xylocarisa. } \\
& \text { Acacia } \\
& \text { yृ } \\
& \text { ชิรา. } \\
& \text { gu }
\end{aligned}
$$

FAGRAA.

The fagrea yields a very hard and excellent timber, which Mr. O'Riley says the teredo will not attack. 'The Burmese regard it as too good for the laity, and say it ought to be confined to sacerdotal purposes. At Taroy it is used principally for the posts of Buddhist edifices.

Fagraa fragrans.

$$
\text { ว๖\$ุด }
$$

Gasn.

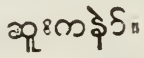

EBONY.

The Karens have distinctive names for four different species of ebony trees. The salt water swamp ebony, the water ebony, the yellow ebony, and the true ebony. I have never met with the trees in flower, so as to be able to distinguish the species; but I have seen specimens of 
the wood in the southern provinces, not inferior to the ebony of commerce.

Diospyros.

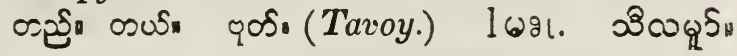

MAULMAIN EBONY.

There is an inferior kind of ebony often seen at Maulmain, which the natives do not call by the same name that they do the trees which produce the good ebony, though evidently a product of the same genus. A similar wood at Tavoy is often denominated iron wood.

Diospyrus.

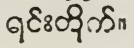

วงกาขำ.

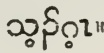

MOUNTAIN EBONY.

Loudon calls bauhinia, mountain ebony, and the wood, though not much like ebony, is quite hard, and might be applied to many useful purposes. To the five species which are enumerated among the flowering plants, may be added a small timber tree bearing a sour leaf, and a pod containing sweet pulp, like the honey locust of America. I have not seen the flower, but the twin leaf is that of a bauhinia.

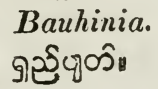

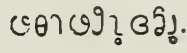

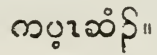

MIAHOGANY.

The genuine mahogany tree may be seen in some of our gardens, where it appears to flourish.

Swietenia Mahagoni.

TENASSERIM MAHOGANY.

'I'he gum kino tree, pterocarpus, or padouk, produces a timber which in its finest specimens bears so strong a resemblance to mahogany that a visitor mistook it for mahogany, and recorded it as such in the book of his travels. At Maulmain, it is called red-wood, and one of the trees, for there are two species, differs very slightly from the tree which yields the Andaman red-wood, of which Rox. 
of the natural family that produces it, affords valuable timber.

Vatica robusta.

Shorea

эEి

(బిబेईn $A$ species of shorea.)

\section{LARD SHOREA.}

On the mountains in the interior is a species of shorea which produces an oil of the consistence of lard, and has been hence named by the Karens "the hog's lard tree." The books say that the shoreas produce resin, and dipter. ocarpus oil, but the fine long scarious wings of the dried calyx afiord incontrovertible evidence that it is a species of shorea.

Vatica, vel Shorea.

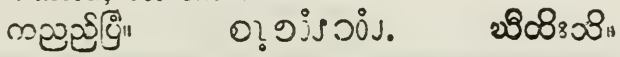

DOUBTFUL SHOREA.

The largest tree in the Provinces of the wood oil tree family, yieds no oil, and is probably a species of shorea; but I have never seen it either in flower or fruit. It is principally used for making large boats, but its places of growth are usually of difficult access by water, and it is not in very general use. Mr. O'Riley says : "It is well adapted for spars for vessels."

Shorea?

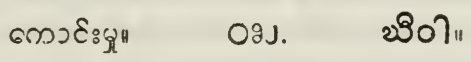

$$
\text { HOPEA.* }
$$

The hopea is considered the most valuable indigenous timber tree in the southern provinces; and at 'Tavoy and Nergui it is sawn up for building purposes. The best canoes are made of hopea, and it is used extensively in native boat building.

Hopea odorata.

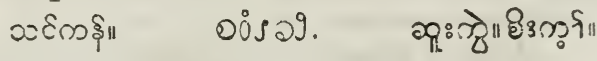

- In America often erroneously spulled hopia. 


\section{VATERIA.}

A species of vateria is a common timber tree in the Provinces of Tavoy and Mergui. The timber is whiter than hopea, and equally good. Indeed, it is often called white thengan, or white hopea, the woods being only distinguished in commerce by their colour. Wallich in his list of Indian woods mentions Hopea floribunda as known at Tavoy by the Burmese name of tantheya. This tree is called at Tavoy pantheya, but it is certainly not a species of hopea. Its flowers, in white fragrant panicles, are often seen in the Tavoy bazar, and are very unlike the yellow secund flowers of the hopea.

Vateria lanceolata?

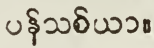
usว่าอr.

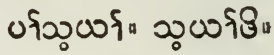

\section{WOOD OIL TREL;}

'Ihe common wood oil tree produces a very useful timber, which is sawn into boards at Tavoy and Mergui, and used in house building. Where not exposed to the wet, they answer as well as teak, and are sold at half the price; but they are not impervious to white ants.

Dipterocarpus lævis.
ఇखై
อุว วอำ.
బิ๐ి

\section{LARGE-FLOWEIRED DIPTEROCARPLS.}

This is a species of wood oil tree which grows on the sandy plains near the sea-shore, and on a similar soil in the interior.

$$
\begin{aligned}
& \text { Dipterocarpus grandiflora. } \\
& \text { э) } \\
& \text { อวดls 3?. }
\end{aligned}
$$

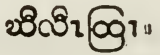

\section{SOUR WOOD OIL TREE.}

This is the name which the Karens give a large tree that grows on their mountains, but which produces comparatively very little wood oil.

$$
\begin{aligned}
& \text { Dipten ocarpus. }
\end{aligned}
$$

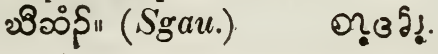




\section{BITTER WOUD.}

The bitter wood a small tree used for boats in the neighborhood of Amherst, is particularly desirable for being, as Mr. O'Riley states, "exempt from the attack of the teredo." I hare never seen the tree, but its leaves and fruit were furnished me by Mr. O'Riley, and they indicate it to be a species of terminalia, and of the section pentaptera. The good timber, and bitter bark assimila:e it to Roxburgh's $P$. Arjuna, but the foliation is different.

$$
\begin{aligned}
& \text { Terminalia (Pentaptera.) }
\end{aligned}
$$

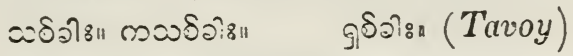

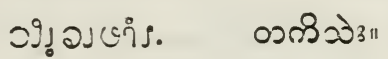

TERMINALIA.

I believe every member of the genus terminalia yields useful timber, and besides the preceding species, two others, the cliebula, and bellerica hare been noticed as indigenous in another part of this work. A still larger timber tree is common in the interior, whose winged fruit indicate its connection with Roxburgh's genus pentaptera.

Tcrminalia (Pcntaptera.).

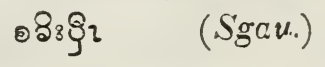

\section{CHASTE TREE.}

This is a species of vitex very common at Maulmain, which produces a valuable small timber. Roxburgh says "Wood when old, chocolate coloured, very hard, and durable."

$$
\begin{aligned}
& \text { Vitcx arborea. } \\
& 6002 \text { ถูตวะ }
\end{aligned}
$$

\section{GMELINA ARBOREA.}

Wallich met with this tree on the Salwen, but it has never fallen under my observation, and I am unacquainted with its native name. It produces, howerer, a useful timber, "not readily attacked by insects."

Gmelina arborca. 
TOON WOOD.

Lieut. Nuthall, as quoted by Captain Munro, mentions toon as one of the woods of Arracan, under the name of "thit-ka-do." We have, however, the authority of Wallich for saying that thit-ka-do is a species of sterculia, a genus that produces no valuable timber. Still, as it is possible that there may be only a mistake in the name while the thing itself exists, the remark is worth putting on record.

Cedrela Trona. werso:

A CACIA.

Sirissa acacia is found on the Irrawaddy, and may exist in these Provinces. It is a large tree, and its wood is "dark coloured, and very hard." The fragrant acacia is indigenous in the Provinces, and is said to yield " a hard and strong timber." 'The largest timber tree belonging to the genus with which I am acquainted, is a common forest tree, and from the character of the genus would no doubt furnish raluable timber.

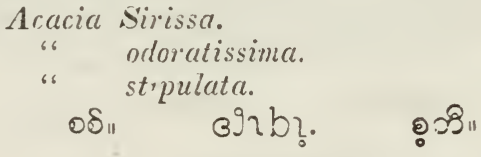

DALBERGIA.

There is a large timber tree found throughout the Provinces, sometimes wrought into canoes, which I think is a species of dalbergia, but $\mathbf{I}$ have never seen it in flower. It is the tree of which, according to Burman geography, there is an immense specimen growing on the Great Eastern Island.

\section{Dalbergia?

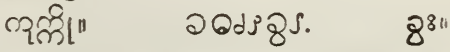 \\ CHISEL-HANDLE TREE.}

A common forest tree produces a hard, fine-grained wood which the Karens call the egg tree, and the Burmese the chisel-handle tree, its wood being imuch used for chisel handles. I have nct seen the flower, 
but the fruit identifies it with Roxburgh's genus dalbergia. Dalbergia.

086003 กริ"

$$
\text { วงูงใดาง. }
$$

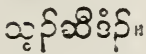

MAULMAIN LANCE-WOOD.

There is a tree found all over the Provinces which yields a wood that the residents at Maulmain sometimes call lance-wood. 'The Karens make bows of it, but prefer Cassia fistula. I have never met with the tree in flower, but think it a species of dalbergia, though it may possibly be a cassia.

Dalbergia?

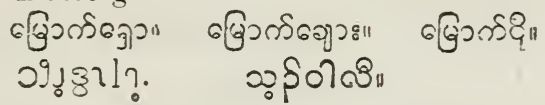

OA K.

Wallich found seven different species of oak growing in Burmah and on this Coast. Three or four are natives of the Provinces, and all afford useful timber, though in ferior to the English oak.

$\begin{array}{cl}\text { Quercus fonestrata. } \\ \text { " } & \text { turbinata } \\ \text { velutina. }\end{array}$

00050

Quercus Amherstianus

Tirbbce.

IFall.

JAROOL.

The queen lagerstrœmia, or jarool, is an abundant timber tree in these Provinces, thmigh very scarce on the other Coast. The posts of an old wharf at Tavoy which were of this wcod, stood erect for tiventy or thirty years; but house posts often decay in the ground in a much shorter period. It is considered a raluable timber in ship building. 'There is a smaller species of lagerstrœmi a in our jungles whose wood is inferior, but it is some. times confounded with the other.

Lage"stramia Regina.

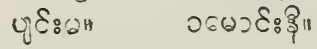

पुर्ष०० इล०วह:प्षा"
8?.

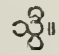

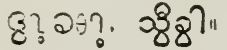

(Inferior timber.) 


\section{GREWIA.}

At Tavoy, when vessels require spars they are usually furnished from a small tree wh:ch grows on the sea-board, belonging to the genus grewia.

Grewia.

cะธิ์

CALOPHYLLUS.

House carpenters often use the timber of a species of calophyllum, and this tree also furnishes spars.

Calophyllum.

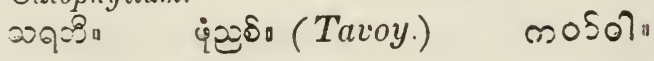

GARCINIA.

A timber tree, the largest that I have seen of the genus garcinia, is in frequent demand for house posts in Tavoy. Garcinia.
งคุดใด
טoj. vof.

GORDONIA.

Gordonia is called "itch-wood" by the Tavoyers, from the itching which its chips or bark occasion when brought in contact with the skin. I have often seen its compact timber used for house posts, and for rice inortars.

$$
\begin{aligned}
& \begin{array}{c}
\text { Gordonia floribunda. } \\
\text { integrifolia. }
\end{array} \\
& \text { พธ์คว }
\end{aligned}
$$

\section{MANGROVE.}

The species of mangrove most abundant along our shores furnishes a hard and durable timber. The tree is easily distinguished from its associates, for it drops no roots from its branches, but the trunk is divided into numerous roots for half its height, like a small bamboo pavilion.

Bruguiera Rheedii.

Rhizophora gymnoritiza.

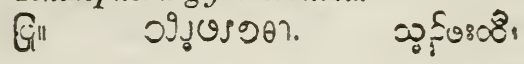




\section{CAREYA.}

An arboreous species of careya, a genus named after Dr. Carey, furnishes a useful timber for house building. In some parts of India matchlocks are made from a spe. cies of careya.

Careya arborea.

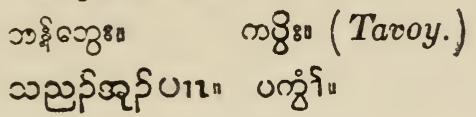

บจำ.

\section{MOUNTAIN JACK.}

The mountain jack is deemed a valuable timber by the natives, especially for canoes. Wallich says: "It produces a sort of caoutchouc, with which the Burmese pay their bnats." I imagine this is a mistake. The Burmese almost universally pay their boats with a substance that is produced by a bee, mixed sometimes with dammer. Artocarpus echinatus.

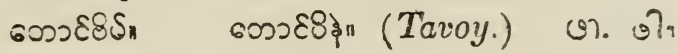

WILD NUTMEG TREE.

There are one or two trees, which I have noticed in the southern provinces, belonging to the genus which contains the nutmeg. The fruit has none of the aroma of the nutmeg, but the timber which is large, is used by the natives in house carpentry. Griffith found only one species, "apparently," he says, "referable to Lourier's genus knema." Wallich, however, met with two, and referred both to myristica.

$$
\begin{aligned}
& \text { Myristica amygdat" } n a \text { ? } \\
& \text { " spœrocarpa? }
\end{aligned}
$$

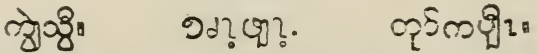

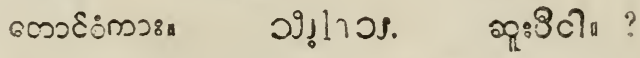

BIGNONIA.

The Karens often build their boats with the wood oi a species of bignonia, as the genus is defined by Roxburgh; 
and the timber which is sometimes large is frequentity used in joinery.

Bignonia.

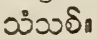

งวางางรา.

కిరి

SOUR SONNERATIA.

A species of sonneratia abounds in the mangrove swamps, and on the banks of almost every stream on the coast as far as tide-waters reach, which the natives use for various economical purposes, and it is said to be "a better substitute for coal in steamers than any other kind of wood."

Sonneratia acida.

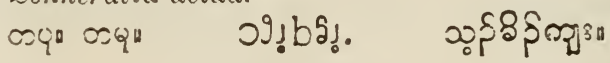

LAUPUS.

A solitary post of a species of laurus is often found in Tavoy houses. There was one in mine, which the white ants selected in preference to all others; and as long as left undisturbed, they nerer wandered from home It may be an advantage to have one post in a house of this timiber, but one is quite sufficient.

Laurus.

uई:\$ ஸว:

KYANAN.

On the low lands near the sea-coast there is a large tree of which canoes are oceasionally made, that is much used for sandals. The wood is red, but turns black on being anointed with petroleum. I have never seen the tree either in sower, or fruit; but it has pinnate leaves, with two pairs of oval leathery leaflets, and is, I imagine, a leguninous tree.

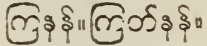

MAYBYOUNG.

This is a hard, tough, knotty wood, which the Tavoyers select for anchors to their large boats, wooden anchors laden with stones constituting the greater part in use. I have never seen the tree.

$$
\begin{aligned}
& \text { बेop? } \\
& \text { 32! }=071 \\
& \text { eฉ: }
\end{aligned}
$$


BEEF-WOOD.

Beef-wood is imported into the United States in considerable quantities, for various purposes where a hard heavy wood is required, and the casuarina on our Coast can furnish almost any quantity of this timber, but it is very little used. Roxburgh says it resembles toon in appearance. The natives call it by the same name as the pine. Casuarina murica:a.

$$
\text { œ }
$$

The soondree is a gloomy looking tree that may be distinguished from all others for many miles distant. It is remarkably characteristic of a peculiar soil. Wherever the tides occasionally rise and inundate the land, this tree is sure to be found throughout the whole Coast, but it is never found at home, either on the high dry lands on the one hand, nor in the wet mangrove sivamps on the other. It is the tree which was described by Dr. Buchanan Hamilton, who acconpanied Symmes' embassy, as $H_{t r i-}$ tiera Fonres. It is the toughest wood that has been tested in India. When Rangoon teak broke with a weight of 870 pounds, soondree sustained 1312 pounds. It is not a very durable wood, but stands without a rival in strength. although so common on the other Coast, as to give name, as Captain Munro thinks, to the Soonderbunds, yet the tree grows much larger in these Provinces, and affords finer timber.

Heritiera minor.

“ Fomes.

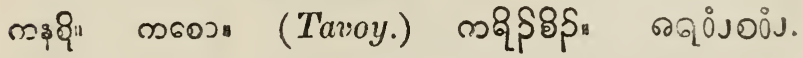

TRINCOMALEE WOOD.

Dr. Helfer mentions the tree which produces the Trincomalee wood as growing on King's Island opposite Mergui. It is a light, strong, valuable wood.

Berrya Ammonilla.

MARTABAN CAMPHOR WOOD.

This is a very large tree, scattered sparsely throughout the Provinces. Wallich wrote that it was very like Lau- 
rus glandulifera, which furnishes the sassafras, and camphor wood of Nepaul. The Karens call it the "tree galanga," from its fragrance.

$$
\begin{aligned}
& \text { Laurus. (Sassafras.) } \\
& \text { ल) } \\
& \text { วิชวำ? }
\end{aligned}
$$

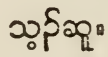

SASSAFRAS.

A species of laurus with the odour of sassafras, is often used in house carpentry.

Laurus. (Sassafras.)

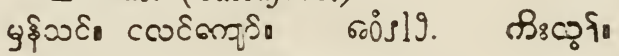

ODINA.

At Maulmain a species of odina is quite common, which produces a raluable wood.

Odina Wodier.

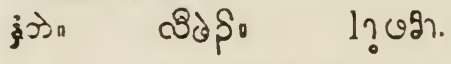

MOOTCHEE WOOD.

A species of erythrina supplies a soft, white wood, as easily worked as the pine, which might be made available for many economical purposes.

Erythrina indica.

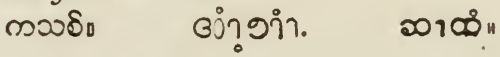

MOUNTAIN CORAL TREE.

A fine looking timber tree of the same genus as the preceding, but producing a reddish wood, is not uncommon in the interior. The Karens select the tree in preference to all others on which to train their betel vines.

Erythrina.

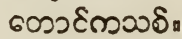

ఆอำวยา.

నาะ"

KYAIZAI.

A species of laurus producing a hard wood used in carpentry, is seen in Tavoy, where it is called kyaizai.

Laurus.

केणे।

วำวงจุดรดัง.

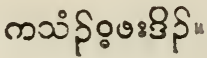


YAMANEE.

There is a tree on the hills which furnishes a remarkably light, white timber, resembling mootchee wood, of which the natives often make canoes. I have never seen the tree, but the Karens say it bears a yellow flower, and a small plumb which is a favorite food with the barking deer.

$$
\text { W0650 श2. ल2\% }
$$

\section{ELCEOCARPUS.}

A hard raluable timber tree is very abundant in the neighbourhood of Rangoon, and not uncommon in some parts of these Prorinces, belonging to the genus elœocarpus. Carts are sometimes constructed of it, and it is used in house and boat building.

Elcearpus.

6000000

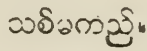

\section{SALWEN.}

The river salwen derives its name from a tree that grows on its banks of that name. I have never seen it, but from the fruit that has been brought me, I am enabled to state that it is a species of elœocarpus, and from the character of the genus, would probably yield useful wood.

Elcocarpus.

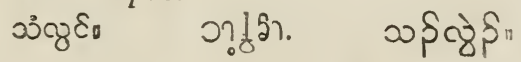

BLACK WOOD.

Under the Burman name of yendaik, the wood of two different trees is sometimes seell. One, a species of ebony, and the other a leguminous tree which, according to the descriptions of the Karens, is a species of dalbergia, and the wood resembles the black wood of Hindustan.

Dalbergia latifolia?

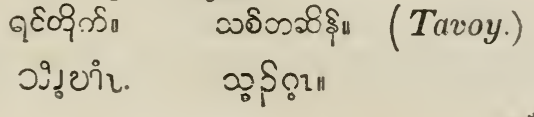




\section{TENASSERIM LANCE-WOOD.}

A tree which produces a timber possessing the proper ties of lance-wood is not uncommon in the Provinces, but it belongs to the dog-bane tribe, and is not at all related to Guatteria virgata, the lance-wood of commerce.

Apocynacere.

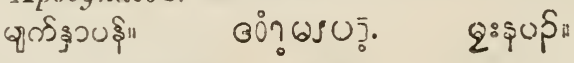

BCRMAN BOX-WOOD.

The Karens have somerimes furnished me with speci. mens of a wood that can scarcely be distinguished from the bux-wood of Europe, but I have never seen the treeWallich found Nanclea cordifolia on the banks of the Irrawaddy, which has "wood coloured like that of the bos: tree, but much lighter, and at the same time very close grained." It may possibly be the same tree, although the 'Tenasserim wood is not light; or it may be a Tavoy tree, which he says has " a strong tough wood, in grail? like box."

\section{Iilurvaya. oufosurn}

SELUEG BOAT TLMUER.

The Selungs of the Mergui Archipelago shoot orer their waters with remarkably light boats, and they owe then buoyancy to the materials that furm their sides, which are the stems of the edible zalacca. 'These stems are as light, and of the consistency of cork, for which they are often substituted; and the Selungs are skilful 111 uniting them together to serve instead of planks, s) as to make an unequalled sea boat, that floats on the raves like a swan.

Zalarca cdulis.

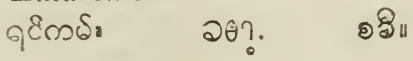

DAMMER PINE.

Grifhith mentions Agathis loranthifiora, or the dammer pine, as a member of the Tenasserim Flora, and I have seen the young plants of the tree to which he must refor. 'The leaf is precisely that of the damme: pine, but 
it is not known to yield any dammer. The wood is white, rather light, and bears considerable resemblance to some kinds of pine. It is used by native carpenters for various purposes, and the Burmese have a superstition that the beams or balances of their scales ought to be formed of this wood. They call it thectamcn, the tree-god vernor.

Agathis loranthifolia.

ov 2 हो

0.8011s.

ஸํํำำ

\section{IINE.*}

Some twenty years ago the residents of Maulmain were not a little surprised to find, among the drift wood of the Salwen, a log of some coniferous tree. This was the first intimation that any tree of the pine tribe grew on the borciers of these Provinces; but whether it were of the genus pinus, or abies, or larix-a pine, a fir, or a larch, did not appear. It was several years after this oceurrence, that one of our former commissioners told me he had offered a hundred rupees to any of the foresters who would bring down a spar of this tree. Spars have been since brought down, but it is believed that dapt. Latter was the first European to visit the locality where the tree is indigenous, and from specimens of the foliage and fruit, which he brought away, it appears to be a new species of pine that may be characterized thus:

P. Lattcri. Arbor 50-60 pedalis, cortice scabro, foliis geminis $i \rightarrow$ uncialibus caniculatis serratist scabbriosculo, strobilis 4 uncialibus orato-conicis, squamis rombeis inermis.

Hab. In provincia Amherst : in convalli Huvii Thoungyecn.

Descr. A tree of from 50 to 69 feet high, or more, and from $1 \frac{1}{2}$ to 2 feet or more in diameter. Sheaths of the leaves arranged spirally, tubular, membranous, six

- Extracted from an article communicated by the author, in the Journal of the A iatic Society for January $1 \leq 49$.

+ Lindley says of the order, "Leaves-entire at the margins;" but these are cortainly tinoly scrrated; and I find $P$. cocclea described with leaves "tootlu bited." 
lines long. Leaves two from each sheath, equal, from 7 to 8 inches long, acute with a sharp point, convex on the back, slightly scabrous with eight rows, in pairs, of very minute thorns which produce a striated appearance, hollow on the under surface, serrated. Cones ovate-conical, nearly four inches long. Scales rhomboid, unarmed.

The flower is unknown. A single ripe cone that had cast its seeds, and a branch, being all the materials furnished for description. Specimens of the wood that have been brought in contain more resinous matter than any other species of coniferæ I ever saw. It appears like woody fibre immersed in resin. The Karens make tar from the wood, by a very simple process; and large quantities of both tar and pitch might be manufactured in the forests, if a remunerative price could be obtained for the article.

The tree is not found west of the Donaw mountains, a part of an unbroken granite range that runs down from the falls of the Salwen to the old city of 'Tenasserim, and which here separates the valley of the Thoungyeen from the region watered by the Gyaing anci its tributaries.

This pine is not among the twoenty four species described by Loudon as the denizens of Great Britain, nor among the twelve species described, and figured by Michaux in his "North American Sylva"; yet it may after all, prove to be a variety of $\boldsymbol{P}$. longifolia, which it more closely resembles than any other species, but from which it differs, among other things, in having only two leaves to each sheath in the specimens I have examined, while that has three. Previous to publishing the abuve communication, a friend, Mr. Laidlay the Secretary of the Asiatic Society, subınitted it to Dr. li'Clelland, while he was in charge of the Botanical Garden, and that gentleman, with $\boldsymbol{P}$. longifulia growing in the garden before him, gave it as his opinion that the Tenasserim tree was a new species. If I have erred, therefore, in regarding it as such, I have done so with the highest official botanical authority in India.

Pinus Latteri.

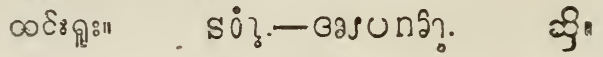




\section{MA M MALIA.}

Few persons are aware of the great difficulty that exists in ascertaining the species, and sometimes the genera of animals in an unexplored country, as these Provinces were some twenty years ago. At that time the rusa deer was, according to some authorities, a wild cow, and according to others, an elk; the gaur was a bison; the paradoxure, a racoon; the bamboo rat, a mole; the wild hog, a barbyrussa; the gymnura, an oppossum; the wild dog, a wolf; the leopard, a cheetah; a deer the nylghau; the goatantelope, a wild sheep; and we had "a goat with one horn resembling the celebrated unicorn," and twenty other animals which are now as really extinct in the Provinces as the mammoth and the megatherium, and for which one would no more think of looking than for the Dean of Westminster's pet, which he describes as

"O'er bog, or steep, throuch strait, rough, dense or rare,

With head, hands, wings, or feet, pursues his way,

And swims, or sinks, or wades, or creeps, or flies."

In those days the jungle traveller was entertained at evening by the natives around the brush fire, with wonderful descriptions of the extraordinary animals, that peopled the surrounding forests. One was found exactly like an elephant, but never had tusks, and was banded across the body with white This proved to be the tapir. Another had a skin like a cow, a mane like a horse, and horns like a goat-the goat antelope. The third was half a dog and half a hog - the sand-badger. And a fourth was represented as in a transition state towards a monkey, just such an animal as would certainly become a monkey in the next state; this was the loris.

Since Mr. Blyth became Curator of the Museum of the Asiatic Society, by far the greater proportion of the mammalia of these Provinces and Arracan has passed under his eye; and to him we are principally indebted for our knowledge of species.

- The Pterodactyle. 


\section{MONKEY TRIBE.}

Fire species of Quadrumana, the monkey tribe, have been found in these Provinces, and the Karens have names for two others, a small grey white-eyelid monkey, and a red-rumped pig-tailed nonkey ; $\dagger$ but these may prove to be varieties of the other species. Arracan has two species that hare not been seen in these Provinces.

\section{WHITE-HANDED GIBLON, Or LONG-ARMED APE.}

The first sounds that usher in the morning in the Karen mountain glens, are the wailing cries of the gibbons on the hill sides around. The whole of the interior of the Provinces is alive with them; and their habit of screaming as soon as the day dawns is celebrated in Karen poetry.

There are all varieties of shade in their colouring, from tawny white to jet black.
Hylobates Lar,
Grand Gibbon,
Ogilby.
Homn Lar,
Simia longimana,
Buffon
Simia Lar,
Pithecus Lar,
Simia albimana,
Hylobates Lar,
Hylobates albimanus,
Linne, Mantiss.
Schreber.
Linne Syst.
Desmarest.
Vigors and Horsfield.
Lesson, apud Martin.
Schinz.

LIGHT-COLOURED VARIETY.

Pctit Gibbon,

Buffon.

Hylobatcs variegatus,

Hi, lobatcs lcuciscus,

Ogilby.

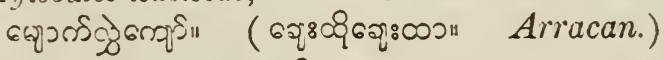

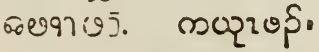

HOULOCK GIBBON.

The long armed ape of Arracan is a different species from the preceding, which is the only one that has

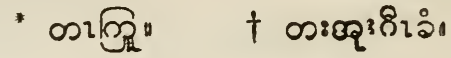


been found in these Provinces. Both are called by the same native names.

Hylobates hoolock.

\section{WHITE-EYELID MONKEY.}

This black monkey has a white ring around the eyes, which gives it a peculiar appearance, and is probably the negro monkey of Pennant. It is found in considerable numbers in the interior, but is not so numerous as the other monkeys, and the gibbons. Though heretofore regarded by Mr. Blyth himself, as identical with $S$. obscurus, he has recently written me that he now considers it the same as.S. Phayrci, a new species, which he described originally from Arracan specimens.

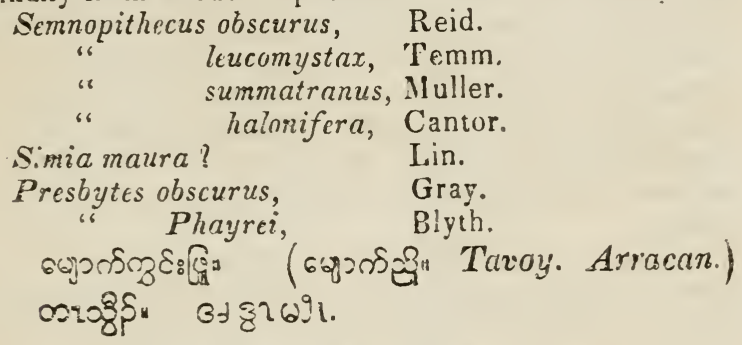

BARBE'S WHITE'EYELID MONKEY.

This monkey abounds in the forests of Yay, and is zearly allied to the preceding species. Mr. Blyth says : "It is intermediate between $P$. Phayrei and $P$. obscurus; but seemingly, distinct from both. 'There is no vertical crest, as in the former; nor is the occipital hair lengthened and conspicuously much paler, as invariably in the latter species: but the shoulders and outside of the arm are silvered in both specimens; and the under parts resemble those of $\boldsymbol{P}$. obscurus. The tail is very slightly paler than the body; whereas in twelve adults of $P$. obscurus (lying together before me, at the time of drawing up this description), the tail is in every one much paler than the body."

$$
\text { Presbytes Barbei. }
$$




\section{FISHER MONKEY.}

Thi3 monkey is more numerous in individuals than any other species in the Provinces. It abounds on the sea shores, and on the banks of inland streams, especially on tide-waters, where it appears to draw a large portion of its sustenance from the crabs, and shell-fish found on the banks. Hence the Burmese have named it the "fisher monkey," and when the tide is out, a whole troop is often seen issuing from the jungle to conchologize. Some are observed turning over stones in diligent search of shellafish, others breaking up the shells they have found to get at the animals within; but most seem to be in search of small crabs, and wherever the trace of one appears, a monkey will thrust down his arm up to the shoulder, if necessary, to draw it out of its hole. Fruits, however, are as acceptable to them as shell-fish. On one occasion, coming down close in-shore at the mouth of the Tenasserim, a troop of them followed my boat for a considerable distance, being attracted by the plantains that we threw out, which they picked up and ate with great aridity.

The apes, that Solomon's fleet brought from Ophir, were probably monkeys of the genus to which this species belongs. They abound in Hindustan, and their Sanscrit name is kape. The Hebrews and Greeks appear to have adopted the name by which the animals were known in their native country, for they were called in Hebrew koph, and in Gieek kcephos, and kerbos, which Scapula says, was an animal of the genus simia, "hav" ing a tail-caudem habens;" so they were not apes, as the word is used in zoology, but monkeys.

Cercopithecus cynoinolgus, Ogilby.

simia cynomolgus,

Simia aygula,

Linne.

Simia attys,

Macacus cynomolgus,

Simia fascicularis,

Linne.

Schreber.

Cercocebus aygula, Inuus cercopithecus,

Desmarest.

Raffles.

Geoff. apud Horsfield.

बशुว $\delta$ oscin

․ 32997 ตํ.

Blyth. 


\section{COALY-MONKEY.}

The coaly-monkey is common in Arracan, where it has the same vernacular names as the preceding species, which it much resembles.

\&accecus carbonarius.

‘ cancrivorus, Blyth.

\section{LONG-HAIRED PIG-TAILED MONKEY.}

This monkey is least common of all the species in the Provinces, but it is most frequently seen in confinement. It is found inland, but rarely if ever on the banks of streams.
Inuies arctoides,
Blyth.

Macacus "

It has been referred to the following allied species :

Papio nemcstrinus,

Simia nemestrinus,

Simia Platypygos,

simia fusca,

Hacacus nemestrinus,

Simia carpolegus,

Lizus nomistrinus,

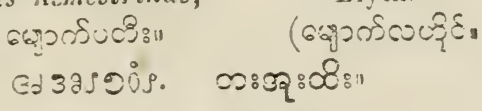

Ogilby.

Linne.

Schreber

Shaw,

Desmarest.

Raffles.

Biyth.

\section{LEMUR, OR LENGAL SLOTH.}

The lemur, Bengal sloth, or slow loris, as it is various sy named, is found in the Provinces, but is not abundant. The Karens say that were it to enter a towa, that towa would assuredly be ciestroyed.

Fyrticúnes tardigrailus,

Lemur turdigradus,

Nycticebus bengalensis,

ivycticebus jaianicus,

Loris tardigradus,

Stcnops joevanicus,

Stenops tardigradus,

Waterhouse, Cat.

Linne apud Raffles.

Geofi.

Geort.

Geoff.

Van der Hoeren.

Waggıer, apud Schinz.

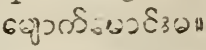

$$
\begin{aligned}
& \text { (6) }
\end{aligned}
$$




\section{BAT TRIBE.}

The Cheiroptera, or bats, are numerously represented in these Provinces and Arracan; but little progress however has been made in the identification of species. Four are known, but they are not probably a moiety of the number that exists.

\section{FLYING POX.}

This large bat has been very appropriately named, for it bears a strong resemblance to a small fox in every thing but its wings. Nor is it very smaill. Adults measure from three to four feet across the wings from tip to tip. They abound on the Coast, and it is quite impossible to beep ripe fruit from their depredations, without inclosing it in basket work. When guava trees are bearing, half devoured fruit will be folnd under them every morning, which the flying foxes have rejected. In some sections they may be seen in great numbers hanging by their heels in the tops of palmyra palms.

$$
\begin{aligned}
& \text { Pteropus edulis, } \\
& \text { " javanicus, }
\end{aligned}
$$

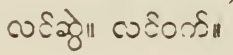

Geoffroy.

Desm. apud Horsfield.

Geoffroy.

(ग)

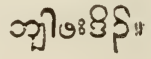

CAVE EAT.

Every one who visits the limestone caves of the Tenasserim coast is startled with their bat-wing music. Suddenly on entering these subterranean halls, thousands of bats rush from their dark recesses, and wheel over the traveller's head with the deep whizzing sounds of a passing water-spout. And then they hang trembling and rustling their wings in the lofty black galleries above, hke a choir of wind harmonies muffled in the mountains.

The large quantities of guano accumulated in the caves inhabited by these bats, might be turned to a profitable account by our horticulturists.

Scotoptrilus Temminchii,

Eespertilio Temminckiii,

Espertilio Bclangerii,
Gray.

Horsfield.

Isid. Geoff: 
Sespertilio noctulinus, Scotophilus castaneus, Nycticeius Temminchii, Nycticeius Belangerii, Nycticcius noctulinus,

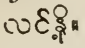

qूगอรว วิ?. 1sid. Geoff.

Gray.

Schinz.

'Temminck, apud Schinz.

Temminck, apud Schinz.

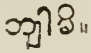

HORSESHOE, OY IEAF-NOSED BAT.

This bat has an appendage on the nose, which is either a horse-shoe or a leaf, at the pleasure of the observer. It is not to be confounded, however, with the phyllostoma, an American genus. The Karens call it the broken-nosed bat. I think there are two species; one is of a yellowish colour. Mr. Blyth has received the two following from Arracan :

$\begin{array}{cl}\text { Hipposideros vulgaris, } & \text { Gray. } \\ \text { Rhinolop.ius "“ } & \text { Horsfield. } \\ \text { insignis, } & \text { Temun. }\end{array}$

lipposidcros larvatus, Horsfield.

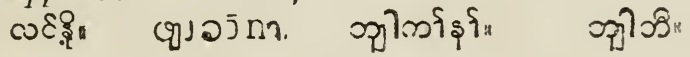

SMAI.L BAT.

The smallest species of bat in the Provinces differs from all the preceding, both in form and habit. It ought to be called the domestic bat. I had one quite domiciled in my house, where it would hang by its heels all day, under the bedstead, without creating the least disturbance. But when night came on it would make a few evolutions round the room, and then fly away. It was always, however, home again by daylight in the morning.

On another occasion, a whole family took up their abode in a small space between a post in the house and a partition: and they are often found in the hollow ends of bainboos in the roof. In an old brick building that Dr. Judson occupied in Rangoon, they were so numerous in the upper story, that he killed two hundred and fifty in one day.

$$
\text { ๗है? }
$$




\section{IXSET-EATERS.}

'Three genera of Insectiv' discovered in the Provinces.

\section{JAVANESE TUPAIA.}

The tupaia is a small animal resembling a squirrel, but with a longer head. It was first discovered in Java, wher it is considered by the natires as a species of squirrel In dentition it resembles the hedgehog.

The Karens describe a striped species as inhabiting their forests, larger than the above.
Tupaia javanica,
Horsf. Lesson.

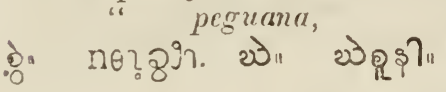

MUSK SHREW.

'The musk shrew is usually called in India the mush rat; but it is a very different animal from the musk rat of America. We have at least two species, both of which emit an offensive odour, so nuch so that when put together with a cat in the same box, the cat will not touch them. They are readily distinguished when in a house from the common rat, by a peculiar shrill squeel which they frequently utter.

I sent Mr. Blyth a specimen of the smallest species, and he wrote: "Mr. Gray identifies this minute shrew with $\mathrm{s}$. pusillus, S. G. Gmelin, Reise III, 499, t. 75, f. 1, and suggests it to be the S. pygnceus, Pallas, S. exilis, Gm. Syst. Nat., and S. cacutiens v. minutus, Laxm."

Sortx Peyrotctii,

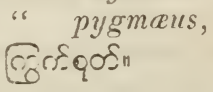

Guerin.

Ilodgson.

oge.

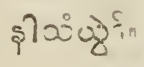

GYMNLRA.

Mr. Blyth says: "The genus gymnura has been ascertained to exist in the Provinces, being probably the nppo:sum of Capt. Low; if not also the marsupial adrerted to by Dr. Helfer."

Gymmura Raflesii? 


\section{CARNIVEROUS ANIMALS.}

The C'arnivora, or carnivorous animals, count between wenty and twenty five species in these Provinces; and two or three others in Arracan.

MALAY BEAR.

The Malay black bear, much resembling the black bear of America, is not uncommon in the interior. On one occasion, while sleeping in a Karen field that had been recently harvested, I was disturbed all night by a drove of them digging up the roots of the sugar cane that had been left in the field. They will occasionally attack a man when alone. On descending the Tenasserim a few years ago on rafts, the foremost raft passed over a rapid, and made a short turn into a little cove below, when a bear from the shore made a plunge at the raft, and threw the two $K$ arens on it into the water. At this moment the other rafts came in sight, and the bear retreated. On another occa. sion I met with a Burman and a bear that he had just shot, and the Burman assured me that he shot the bear in the very act of running upon him.

The Kemees and Karens describe a smaller species, yellow on the breast, for which they have a distinctive name; but $\mathbf{I}$ imagine it is a variety of the above. The Burmese and the northern Karens say there is a species with feet and hands like a man, which they call man-bear. 'This I suspect to be a fabulous animal, founded on reports of the orang-outang.

Ursus malayanus.

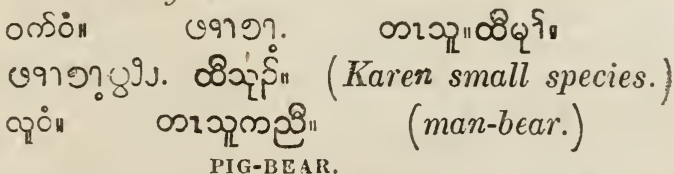

The pig-bear, or sand hog, or Indian badger, or sand badger, as it is variously named, is not rare, especially in the southern provinces. It has the general appearance of a hog, with claws like a bear, but the Burmans say it is half hog and half dog.

Arctonyx collaris.

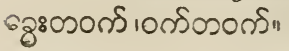

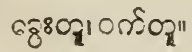

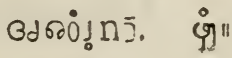




\section{MOKKEY-TIGER.}

'I'his animal was first discoverd in Malacca a few yeary ago, and it is not known to exist north of these Provinces, though it is probably found to some extent in Burmah Proper. Monkeyatiger is a translation of its Burmese name, and is somewhat descriptive of its character. It is about the size of a small monkey, with a long retractile tail, and is both arboreal and terrestrial in its habits.

Arctictis Binturong,

Viverra? Binturong,

Privadoxurus albifrons,

Ictides ater,

Arctictis penicillata,
Fischer.

Raffles.

F. Cuvier.

F. Cuvier.

Temminck.

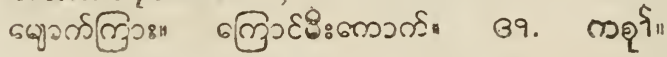

W EASEL.

Capt Phayre met with an animal of the weasel tribe in Arracen, and it probably exists in these Provinces, though it has not yet been discovered.

The Hebrew word rendered wsasel, in Leviticus, is iden fical with the Arabic kihalad, which signifies a mole.

$\begin{array}{ll}\text { Hrlictes Nipalensis: } & \text { Hodg. } \\ \text { liulo arientalis, } & \text { Horsf. }\end{array}$

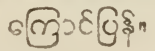

OTTER,

Citers abound in some of the streains. In the upper purt of the 'lenasserim, a dozen at a time may be occa* sumally seen on the rocks in the river. The Burmese sumetimes domesticate them, when they will follow a man like a dog.

Luti a leptonyx.

Cutra Barang,

Blyth.

"Liarang Barang" or Amisang,"

Raffles.

t.uldr vimung.

Raftles.

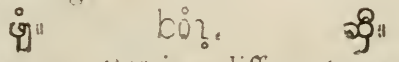

The Arracanese otter is a different species.

Letra Nair,

cestre indica,

Fred. Cuvier.

Gray. 
DONESTIC DOG.

Among the introduced animals, is the domestic dog. Canis familiaris.
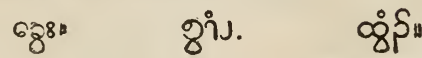

WILI) DOG.

There is a wild dog in the Provinces which Mr.Blyth re* gards as a distinct species; and the Karens have described to me an animal that makes his kennel in the ground like a fox or a jackal, which they say is found in the Shan coun. try. The fox of the English bible is probably the jackal. The Hebre:w word is shugal, the Persian name of the jackal is shaghal and shakal, and the Pali* is thengala or shengala, from the same root, which the Burman books render "earth-dog." $\dagger$

Canis rutilis.

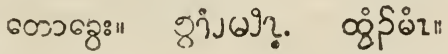

MALACCA CIVET.

The Indian civet-cats secrete an odoriferous substance identical with civet, though not the civet of commerce. 'This species is not infrequently found in the villages, and iis secretion enters into the Burmese Materia Medica.

Viverricula malaccensis.

Viverra malaccensis,

Gmelin.

"Rasse,

Gunda,

" indica,

" bengalensis,

" pallida,

Genetta manillensis,

Horsfield.

Buchanan Hamilton MSS,

Geoffroy.

Gray: Illustr.

Gray : Illustr.

Eydoux.

-ुुग्रnof:n

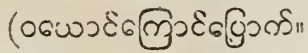

Arracan.)

90ำ30?.

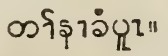

c88ฉ"

ठे? 0830 S.

* 38scon

$+66368: 11$ 


\section{ZIBETH CIVET,}

This is another species of civet-cat, not so abundant as the preceding, which the Burmese call "the horse-cat," from the mane on its neck.

Viverra Zibetha,
"
" melanurus,
" oricntalis,
"ூु॰ civettoides,

Linne.

Gray.

Hodgson.

THREE-STRIPED PAGUMA.

This animal is very common, and occasionally enters houses in the towns in pursuit of rats. When young it is easily donesticated, and valuable as a rat-catcher. It does not appear to have been seen in Arracan.

Paguma trivirgata, Gray.

Iiverra "6 Reinwardt, Mus. Leyd.

Paradoxurus trivirgatus, Gray.

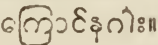

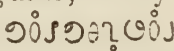
c8sos?

\section{COMMON PARADOXURE.}

This paradoxure inhabits the Provinces, but I hare ne. ver examined the species. It is probably identical with the one in Arracan.

Paradoxurus Musanga,

Viverva hermaphrodita,

"fasciata,

"Nusanga,

Filusang bulan,

Ir.lineumon prehensilis,

Platyschista hermaphrodita,

Paradonurus Pallasii,

"s

66

66

16

6

Crossii,

dubius,
Musangoides, Gray

Gray.

Pallas, apud Schinz.

Gmelin?

Marsden, Raffles.

Raffles.

Buchanan Halmilton.

Wagner, apud Schinz. 
WHITE-EARED PARADOXLRE.

A paradoxure distinguished by white-tipped esor is not very rare in the Provinces.

Paradoxurus lencorhinus, Blyth.

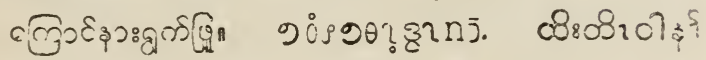

UNDESCRIBEU PARADOXURE.

Al undescribed species has been sent up to Calcutta from two of these Provinces, and from Arracan, but it has not yet received a name. The netives do not distiuguish it from the common paradoxure.

TENASSERIM ICHNEUMON.

This animal is not the genuine ichneumon, but it belongs to the same iamily, and has its habits. It is remarkable for devouring snakes.

Urva cancrivora, Blyth.

$$
\begin{aligned}
& \text { बहिंगी } \\
& \text { nคใชดา } 60 \mathrm{~s} 5 . \\
& \text { कి: }
\end{aligned}
$$

\section{ROY.IL TIGER.}

'Tigers are sufficiently abundant in the Provinces, al1..ost everywhere. Twice during my residence at Tavov they came into the gate of my compound, broke open the c. or of the goat-house, and succeeded in killing a goat exch time before they could be routed. On another occasion, while sleeping in a jungle hamlet, a tiger leaped into a buffalo pen close by the house, and killed a buffalo. They appear to be afraid to encounter a man untsl tiey have once entered the contest with him, when al! lear ceases ever after. I have encamped in the jungles often, where the tracks of tigers were seen all around in the morning within a few yards of where myself and penfie had bivouacked, yet they never ventured an attack Bist whenever a tiger has once tasted human blood it ever atter seeks it in preference to all other.

A Burman was struck down by a tiger at the head o: Tavov river, and he was seen by his companicns to inflict a severe wound on his antagonist with his knife, but 
was carried off. A few months afterwards, a Karen was killed by a tiger in a village twenty miles distant; and when the villagers subsequently succeeded in killing the animal, it was found to have been wounded as described by the Burmans. A Karen was killed by a tiger near a village a dozen miles east of 'Tavoy, supposed to be tie same beast that had devoured a man ten miles distant a short time previous. This Karen was carried off after breakfast in the morning while going out alone to his work in the field; and in less then a week from that time a Burman was struck down by a tiger in the middle of the day, not six miles distant, and when there were eight other men in company.

A Karen who was killed by a tiger near the forks of the Tenasserim, was walking with three others in company a couple of hours before sunset, and had a gun on his shoulder. The Kareus that lived nearest immediately set traps in the paths that led to their villages, and the animal was soon caught near one of their houses.

On one occasion I reached a lone Karen cabin at dusk, and was surprised (o) find it barricaded all around to prevent access. On inquiry I found that two men had been devoured by a tiger the day before in the neighborhood close by. It appeared that one man had been carried off, and five others then armed themselves and went in pursuit. After half a day's search, and while on the track, the beast came cut boldly on the plain and succeeded in carrying off one of the armed Karens that had engaged iu the pursuit.

A few years ago a little body of $\mathrm{K}$ arens removed from Yay, and settled on the apper part of Tavoy river; but after lonsing four or five men in as many different years by the tigers, they have been compelled to descend into the more populous part of the valley.

These few facts, which night easily be multiplied, have been mentioned, because the opinion has gone abroad that Tenasserim tigers are uot dangerous. Dr. Helfer wrote: "They are of quite a different nature from those in Bengal, and probably more afraid of men, than men of them. Accidents very seldom happen to natives, who 
penetrate daily into untrodden jungle', sometimes quite alone."

Such representations may prove fatal to strangers and persons new in the country, as they already have in the case of Dr. Woodford, who lost his life by a tiger on the Ataran a few yeats ago, wholly owing to his want of suitable precaution in going away from the boat near erening to shoot a peacock.
Felis tigris,
Tigris regalis,
copra
จ9ر 69.
Linne.
Gray.

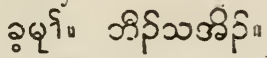

LEOPARD.

Leopards are probably more numerous than tigers, and they will sometimes attack man, though he seek refuge in the tree tops. Two Karens were trarelling on one vccasion in the forests of Maulmain, and when daylight departed, they made little bamboo platforms to sleep on during the night in the branches of a large tree; one on a lower main branch, and the other on an upper large branch. During the night, the man on the lower branch was a waked by what he thought to be a tiger, but it must have been a leopard, creeping up the body of the tree above him. It had passed his branch, and was climbing up to where the other man slept. He called out-the man answered, and the leopard was still-not a claw moved; but the sleeping man could not rouse himself, and in a few minutes the leopard rushed up, seized the man in his sleep, and jumping down with him, desoured him at the foot of the tree, regardless of all the noise the narrator of the story could make in the tree above him.

$\left.\begin{array}{cl}\text { Felis lcopardus, } & \text { Schreber. } \\ \text { " Prrdus, } & \text { Linne,? } \\ \text { varia, } & \text { Schreber. } \\ \text { "Pantherc, } & \text { Erxleben. } \\ \text { "chalybeata, } & \text { Hermann. } \\ \text { antiquorum, } & \text { Fischer. } \\ \text { " fusca, } & \text { Meyer. } \\ \text { Ecopardus varius, } & \text { Ehrenberg, Gray : List. }\end{array}\right\}$




\section{BI.ACK LEOPARD.}

Black leopards, commonly called black tigers, are fre. quently met with in 'Tavoy province. They are dangerous beasts. A few years ago a Burman was devoured by one not eight miles distant from 'Tavoy city.
Felis mela:,
Gray.
Felis leopardus, var. melas, (Blyth.)
लगे।

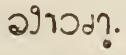
จ्ุर"

\section{LEOPARD-CAT.}

This is the handsomest animal of the tiger tribe in the Trovinces. It is spotted with black, like a leopard, on a yellawish ground, and is as large as a small dog. It is very fierce. A Karen whom I knew was attacked by one and his arm shockingly lacerated; but he was sared by his dog, which seized the cat when it attacked his mas1or, and the man and dog together proved too much for $1 \mathrm{t}$

$$
\text { จรู" }
$$

\section{TIGER-CAT.}

This animal is abous the size of a cat, but its colour and markings are exactly that of a tiger. These cats are very abundant in the jungles, and occasionally venture into towns, where they make great havoc anong the poultry. Capt. Low called it the "fox-cat."
60026लु
פj่ง G?.
कి:

\section{BENGAL TIGER-CAT.}

This is an entirely distinct species from either of the receding, all of which $\mathrm{I}$ have seen, and is much less com. inon.

$$
\begin{aligned}
& \text { Felis Bengalensis. }
\end{aligned}
$$

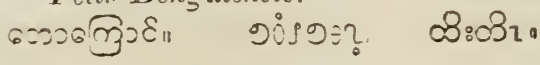

NEPAUL TIGER-CAT.

This animal Capt. Phayre found in Arracan, and Mr. Blyth writes me, "add Felis macrocelis, from Arracan;" but 
he thinks that the above, with the preceding three cats, are probably all varieties of the .Javanese tiger cat.

Felis nepalensis.

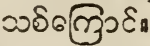

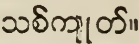

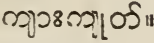

The following names, then, may be regarded as designating the same species.
Felis javanensis.
minuta,
Desmarest.
"bengalensis.
Temminck.
" nepalensis.

chavs.

There is an animal of the tiger tribe which the Karens call the fire-tiger, from the colour of its skin, which is of an uniform red. It is probably the chaus, a large wild car, sometimes denominated a lynx, that Capt. Phayre found in Arracan.

Felis chaus.

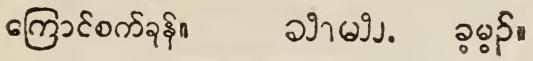

DOMESTIC CAT.

Sir Stamford Raffles says: "Some of the Maylayan, like the Madagascar domestic cats, have a short twisted or knobbed tail." This is a peculiarity that characterizes the cats on this Coast.

Felis domestica.

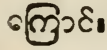

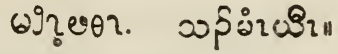

\section{GNAWING ANIMALS.}

Fifteen species of Rodentia, or gnawing animals, are known to exist in the Provinces, and four others in Arracan; while, owing to their small size, it is highly probable that there remain other species to be discovered.

TWO-COLOURED SQUIRREL.

The two-coloured squirrel has been appropriately named the giant squirrel, for it is as large as a cat. It is deep black on the back, and whitish yellow below. Its Karen name signifies the yellow-neck, being more particulariy yellow on the front part of the neck. 


\section{Sciurus bicolor, Sparrmannt. giganteus, M'Clelland MSS.

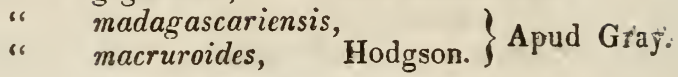 GOLDEN-BACKED SQUIRREL.}

The golden-backed squirrel which bears a considerable resemblance to the American gray squirrel, is peculiar to the Tenasserim Provinces, and like that is considered very good eating. Its general colour is gray, with a tinge of yellow on the back.

It is described by Mr. Blyth, as "the size of Sc.Rafflesii, or measuring about $20 \mathrm{in}$. long, of which the tail is half, its hair reaching $2 \mathrm{in}$. or $2 \frac{1}{2}$ in. further. General colour grizzled fulrous above, the limbs and tail grizzled ashy (from each hair being annulated with black and pale fulvescent), with an abruptly defined black tip to the latter: under-parts and inside of limbs pale grizzled ashy: in bright specimens, the nape, shoulders, and upper-part of the back, are vivid light ferruginous or golden-fulvous, sometimes continued to the tail, more generally shading off gradually towards the rump, and in some but slightly developed even upon the nape and shoulders: whiskers long and black; and slight alhescent pencils to the ears, more or less developed."

$$
\begin{aligned}
& \text { Sciurus chrysonotus. }
\end{aligned}
$$

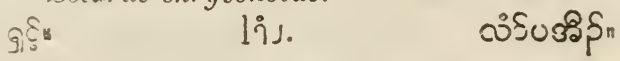

BLACK-BACKED SQUIRREL.

This is an ordinary.sized squirrel, the upper parts griz: zled with black, on a golden ground, with a superb bushy tail.

Sciurus atrodorsalis.

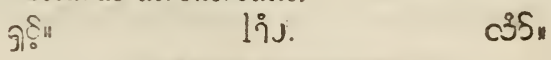

RUSTY SQUIRREL.

The rusty squirrel, first found in Pegu, is met with in these Provinces, but is not abundant. Blyth describes it as according in size " with $\boldsymbol{S} c$. vittatus, except that the tail is longer and more bushy. Entire upper-parts uniformly grizzled, much as in that species, or more especially as 
in the tail of that species-the tip of the tail being black: under-parts, inside of limbs, fore-paws above, and almost the entire hind limbs exteriorly, together with a broad median line to the tail underneath continued to its black tip, bright ferruginous-chesnut; that of the belly bordered laterally with black: whiskers black. Specimen $a$, as signed Sc. erythraus in Mr. Gray's catalogue of the mammalia in the British Museum, seems referrible to this."

Sciurus pygerythrus.

BAREE'S SQUTRREL.

This is a beautiful little squirrel, striped with nine alternate lines of black and rusty white, and somewhat resembling the American ground squirrel. It is, however, new species, abounding in the Provinces of $\mathrm{Y}$ ay, Tavoy, and Mergui.

Sciurus Barbei.

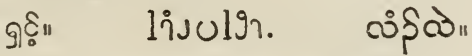

BERDMORE'S SQUIRREL.

This is a large striped squirrel, often seen in the soutl:ern Provinces.

Sciurus Berdmorei.

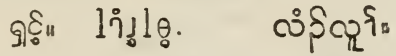

RED SQUIRREL.

The red squirrel has not yet been seen in the Provit. ces, but Capt. Phayre found it in Arracan. It is " entirely of a deep rufo-ferruginous colour, rather darker above than below-toes of all the feet blackish, "tip of the tail yellowish white."
Sciurus Keraudrenii,
Lesson.
" ferrugineus,
Cuvier.

ภยุิ"

\section{ASSAMESE SQUIRREL.}

Capt. Phayre met with this species also in Arracan, but no one has yet found it in the Provinces. It is deacribed as being more or less rufescent all over. 


\section{YELLOW-BELLIED SQUIRREL.}

This is another species which Blyth says inhabits Arracan, but which is unknown in these Provinces.
Sciurus lokriah,
" subflaviventris.
Hodgson.
M'Clelland.

\section{LARGE FLYING SQUIRREL.}

We have one or two species of that graceful, elegant group, the flying squirrels. The largest Blyth regards as a variety of Pteromys petaurista, "but the whitish tips to the fur more predominating, imparting a hoary-grey appearance to the whole upper surface, and continued along the tail, the extreme tip only of which is blackish; under parts pure white, or nearly so, in different specimens: and the rest of the colouring much as in the preceding variety. (?) In both, the white tips to the fur predominate in the newly put forth pelage, and disappear to a great extent as the fur becomes old and worn. In the young of the Arracan race, the black extreme points of the fur are much developed."

In the specimens that I have examined in these Provinces the ears are tipped with white.

Ptcromys petaurista.

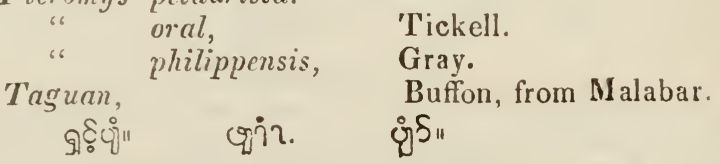

SMALL FLYING SQUIRREL.

The small species inhabits the southern provinces, but no one seems to have obtained specimens. I judge it, howerer, to be identical with the small flying squirrel of Arracan. "A diminutive species about 5 inch. in length, minus the tail, which measures $4 \frac{1}{2}$ inch.; tarse to end of claws $1 \frac{1}{8}$ incl. Upper surface bright ferruginous-bay in old specimens, with the membraue, limbs and tail, dusky, and the basal fourth of the latter pale rufous underneath: under-parts dull white, with fur of a somewhat woolly texture : that of the upper-parts dusky except at tip." Pteromys spadiceus, Blyth. 


\section{BANDICOOT RAT.}

The bandicoot rat is abundant, and its nocturnal depredations in our fowl-houses are very frequent. It burrows in the earth, and rarely appears in the interior of a dwelling house.
Mlus bandicota,
" gigantcus,
" malabaricus,
" perchal,
"Icria,
" nemorivagus, बढ़िला"
eรงs
Bechstein, Hardwicke.
Shaw.
Shaw.
Buchan. Ham. MIS.
Hodgson.

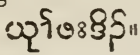

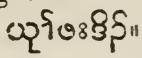

BROWN RAT.

This species usually makes its home in the roofs of houses, and is one of the greatest pests in the country. They will eat into teak drawers, boxes, book-cases, and will try their teeth on almost any thing.
Mus rufescens,
" flavescens,
"rufus,
Gray.
Elliot.

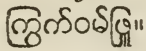
Elliot.
๑ร。

WATER RAT.

There is a water rat in the jungles which appears to have the habits of the European water rat; but Mr. Blyth writes me that he doubts our having a species of Arvicola.

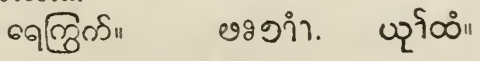

FIELD MOLSE.

The Karens describe a field mouse with the same habits as the field mouse of Europe. According to Karen astronomy, the worth star is a mouse, creeping into the proboscis of the elephant, as they call the constellation of the Great Bear.

The mouse of our English Bible was probably the jer boa, an animal with the habits of our bamboo rat, and like that eaten by the inhabitants of the country where it is found.

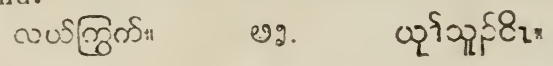

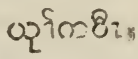




\section{BAMBOO RAT.}

This animal, which burrows under old bamboo roots, resembles a marmot more than a rat, yet it has much of the rat in its habits. I one night caught a specimen gnawing a cocoanut, while camping out in the jungles. The Karens say there are two species, but $I$ have met with only one.

Rhizomys, sumatronsis, Mus sumatrensis, Hypudcus de Sumatra, Nyctocleptes Dctian,

Spalax javanus, Rhizomys chincnsis,

$$
\begin{aligned}
& \text { " cincreus, } \\
& \text { Decan, }
\end{aligned}
$$

Gray.

Raffles.

Temm.

'Temm.

Cuvier.

Gray, apud Schinz.

M'Clelland.

Schinz.

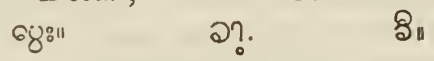

LARGE PORCUPINE.

A large porcupine is not uncommon, but the precise species is not known. It is probably identical with one of the Malay species. The one found in Arracan is the common Indian species, and ours may possibly be the same.

\section{Histrix leucurus.}

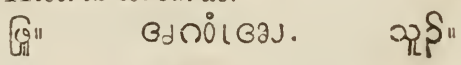

(Arracan)

SMALL PORCUPINE.

There is a small porcupine in the Provinces, which does not appear to have been discovered in Arracan. According to native description, it best accords with the small species described by Hodgson.

$$
\begin{aligned}
& \text { Hystrix alopkas? } \\
& \text { डb?. की. }
\end{aligned}
$$

HARE.

Hares are said to have been seen on the northern borders of the Provinces, and Mr. Blyth is acquainted with one from Pegu, which is the same species without doubt. Lepus anficaudatus, Blyth. บุำ 
RABBIT.

Rabbits have been introduced, and when well tended, they breed rery abundantly.

$$
\begin{aligned}
& \text { Lepus cuniculus. } \\
& \text { ఢః6กวऽही" }
\end{aligned}
$$

\section{TOOTHLESS ANMALS.}

The Edentata, or ioothless animals, have only one representative in these Provinces, and another in Arracan.

\section{PANGOLIN.}

The scaly ant-eater is not very rare here, and so far as I can judge, it is the same species as the one found in Malacca, though there is not a perfect correspondence. It has not the difference in colour at the end of the tail which is characteristic of the Arracan species.

$$
\begin{aligned}
& \text { Manis javanica. } \\
& \text { " pentadartyla, Lin. apud Raffles. } \\
& \text { " aspera, Sundeval. } \\
& \text { " quinquedactyla, Raffles, apud Gray : List. }
\end{aligned}
$$

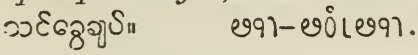

$$
\begin{aligned}
& \text { oินง }
\end{aligned}
$$

ARRACAN PANGOLIN.

The scaly ant-eater of Arracan is another species, but called by the same native names.

$$
\text { Manis leucura. }
$$

\section{THICK-SKINNED ANIMALS.}

Six species of Pachydermata, or thick-skinned animals, inhabit our forests.

\section{ELEPHANT.}

Wild elephants are numerous in the interior, and their haunts readily traced by the mutilations of the bamboos and young trees; but they usually avoid settlements. I have often come upon them on the wild, lone banks of the Tenasserim, and have heard their blowing and heary tramp around my booth by the head waters of Tavoy river. They seem uniformly to avoid the face of man, unless wounded by him, but an enraged elephant is a 
most formidable foe, from which in an open country it is almost impossible to escape. K arens tell us that if one be wounded and not killed, he inmediately retreats, but as soon as he feels the smart of his wound, he turns and rushes upon his antagonist with terrible fury. One of the best Karen marksmen I ever knew perished in this way. He shot and wounded but did not kill the elephant, which immediately ran away. His companions, knowing the habits of the animal, scattered themselves; but this man kept his ground in confidence that he would be able to reload, and renew the attack when it returned; but before his gun was londed, the enraged elephant was upon him, and instantly trampled him to death.

Elephas indicus.

ฉहा

๓8.

WILD HOG.

Whole droves of wild hogs come down upon the Karen paddy fields, and were they not guarded night and day, they would destroy every thing before them. It is a small blackish species, exceedingly numerous.
Sus indicus,
Sus Scrofa,
Sus vittatus,
Sus cristatus, Schinz.
Linne, apud Elliot.
Schlegel.
GCo 0 है।
Wagner, apud Schinz.
Bs"

\section{SINGLE-HORNED RHINOCEROS.}

The common single-horned rhinoceros is very abundant. Though often seen on the uninhabited banks of large rivers, as the Tenasserim, they are fond of ranging the mountains, and I have frequently met with their wallowing places on the banks of mountain streams, two or three thousand feet above the plains. They are as fond of rolling themselves in mud as a hog, or a buffalo. The Karens when travelling have quite as much fear of a rhinoceros as they have of a tiger. When provoked, the rhinoceros, they say, pursues his enemy most unrelentingly, and with indomitable perseverance. If to escape his rage the huntsman retreats to a tree, the beast, it is said, 
will take his stand beneath the tree, for three or four days in succession, without once leaving his antagonist. There are seasons when the rhinoceros is very dangerous and ferocious, attacking every thing that comes near its haunts, yet it is believed the stories related of them are exagerated.

On one occasion while descending the upper $\mathrm{T} \in$ nasserim on small rafts, a rhinoceros was started on the river bank, which ran down the side of the river at a buffalo gallop for about a quarter of a mile, to a ford, with which it appeared to be well aquainted, where it crossed over. Just as it reached the opposite bank, a Karen on a raft near shot at it, and apparently hit the animal, but it rush. ed into the jungle and was seen no more, though we encamped for the night a short distance below, on a small island that was manifestly the resort of the rhinoceros.

A gentleman in Arracan procured a single-horned rhinoceros from the Arracan jungles, and presented it to a friend in Calcutta. In the course of events it passed out of that gentleman's hands, and was ultimately sold to the Zoological Gardens for the sum of one thousand pounds sterling, where it still lives. Rhinoceros trapping, then, might prove no bad speculation.

In the Latin Vulgate the Rhinoceros is put where unicorn is read in the English Bible; and a similar rendering has been adopted in several Indian versions, though unsupported by any philological considerations. The Hebrew name recm bears no resemblance to the name of the rhinoceros in any of the countries adjacent to Judea. In Persian it is called karg.
Rhinoccros unicornis,
" indicus,
Linn.
" asiaticus,
" incrmis,
Cuvier.
Blumen.
तुळ
उd 00 ง $38^{9 \rho .}$
Lesson.

DOUBLE-HORNED RHINOCEROS.

The double-horned rhinoceros is not uncommon in the southern provinces. It differs from the other species not in its horns only, but also in its skin, which is as 
smooth as a buffalo's, while in the single-horned it it disposed in immense folds all over its neck, shoulders, haunches, and thighs; so that it looks as if harnessed in its own natural tackling; and the Karens call it the "coat of mail rhinoceros." The horns of both species are bought by the Chinese for medicine. "From the earliest times," says a recerit writer, "the horn of the Indian rhinoceros has been regarded either as an antidote against poison, or as efficacious in detecting its presence, as well as useful in curing diseases ;" ana the Chinese seem to retain the ideas of antiquity on this subject, as they do on every other.

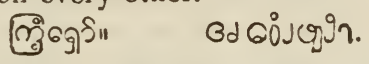

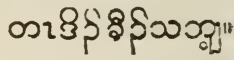

JAVANESE RHINOCEROS.

The southern Karens say there is a third species of rhinoceros in the jungles, which is distinguished from both the others by its skin being covered with small tubercles; and above all by its eating fire! Wherever it sees fire, it runs up, and devours it immediately!

I once lost my way amid the hills and valleys of Palaw and Katay; and on obtaining a Karen who lived in that region for a guide, he laid special charges on every member of the party to follow him in silence, for a fire-eating rhinoceros had been recently seen, and it always came to noises, instead of fleeing from them as most animals do. It is further described as excavating a habitation for itself on the mountain side, in which it remains during the principal part of the dry season, and wanders about during the rains. Amid the marvelous there is sufficient truth in this description to enable us to recognize it as the Javanese rhinoceros, and its supposed fire-eating propensity brings to mind a striking resemblance to the black African rhinoceros, Rh. Africanus. "This animal appears to be excited by the glow of a fire, towards which it rushes with fury, overturning every obstacle. It has been known to rush with such rapidity upon a military party lodged among the bush covering the banks of the Great Fish river, that before the men could be aroused, it had severely injured two of them, tossed about, and broke 
several guns, and completely scattered the burning wood."

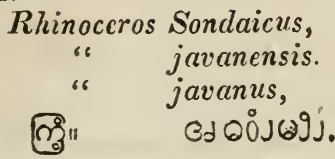

Cuvier.

\section{MALAY TAPIR。}

The tapir has been long known to exist in the south ern provinces, but has never been heard of north of the valley of Tavoy river. It has been known, however, principally from native description that the animal could be no other than the tapir. It is believed that none have ever been killed or captured in the Provinces, except one that was procured from a Karen by a writer of the late Major Macfarquhar at Tavoy. It was a very inoffensive animal, and became as much domesticated as a cat. It followed its master around the compound like a dog, but looked as unseemly as a hog. It differs in no respect from the descriptions of the Malay tapir, has the same white blanket-like appearance on its back, and like that, frequents the uplands. Though seen so rarely, the tapir is by no means uncommon in the interior of Tavoy and Nergui provinces; I have frequertly come on its recent foot-marks, but it avoids the inhabited parts of the country.
Tapirus malayanus,
indicus,
Raffles.
" sumatranus,
"bicolor,
F. Cuvier.
อดดี
उd 8 ?.
Gray.
Wagner.

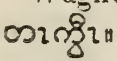

\section{SOLID-HOOFED ANIMAIS.}

Two species of Solidungula, animals with undirided hoofs, have been intruduced.

HORSE.

The horses of Burmah and the Shan country, which ate imported into the Provinces, are small ponies, resem: 
b ling the little Spanish horses that run wild in Missouri, and the other western parts of America.

Equus caballus.
दुE:"
ว๑ง
लos?.

Ass.

Asses are said to be common at Ava, where they are introduced from the north, and a solitary specimen is occasionally seen in these Provirces.

Equus Asinus.

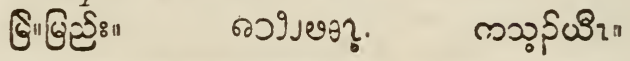

\section{RUMINATING ANIMALS.}

Eleven species of Ruminantia, animals that chew the cud, are known in the Provinces; and it is not probable that any remain to be discoverd.

CHEVROTAIN.

This little deer, about the size of a large hare, is often seen crossing the traveller's path in the interior; but it is by no means so abundant as at Penang, where a dozen may be obtained for a dollar. According to Linnæus, it is a species of the same genus as the musk deer, but it is not known to produce musk.

Tragulus Kanchil,

Chevrotain adulte,

Chevrotain de Java,

Javan Mnsk,

Moschus Palanok,

Mosehus Kanchil,

Pelandok,

Moschus fulviventer,

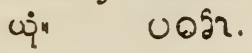

Gray : List.

Buffon.

16

Shaw.

Marsden.

Raffles.

Raffles,

Gray.

०डे,

\section{BARKING DEER.}

The barking deer is more abundant and more univers. ally diffused over the Prorinces than any other species. It is seen occasionally on the hill back of Maulmain, and often in the suburbs of Tavoy. It is very appropriately named, for its bleat, which is constantly heard in the jun gles after night fall, is very tike the barking of a dog. 
It uses its horns with great effect when brought to bay, and according to a Karen fable, the tiger will not attack it. In ancient times, the story goes, when all animals had the power of speech, the tiger said to the barking deer, "O ! barking deer, what is the use of thy horns? It seems to me they would be in my way." The barking deer answered: "A single push of my horns will make the eye of my antagonist start from its socket." On hearing this the tiger was afraid, and never after attempted to devour the barking deer.

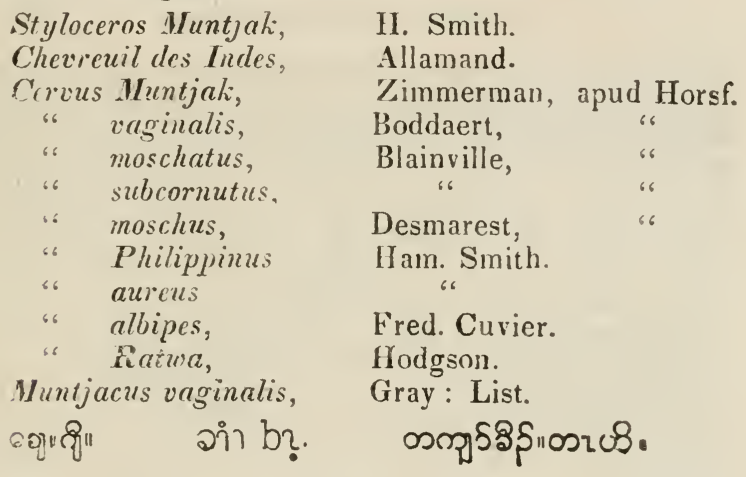

HOG DEER.

This species appears to be confined to the plains. It abounds north and east of Maulmain, and on the large islands south of Tarny; but it is not found north of the city, nor eastward among the hills, nor in the valley of the Tenasserim.

They are often lunted by persons in companies after rark, who go into the plains where they are found, beating tin kettles, and ringing bells, and gongs, which is said to bring the animals to a stand with astonishment, so that the huntsman can walk up, and shoot them at his conrenience.

\section{Cervus porcinus.}
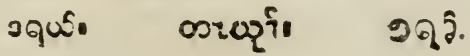
RUSA DEER.

The rusa deer is the one which Europeans cail elk. It is usually found among the hills, and is quite abundant in the interior.

Rusa Equina, Cervus cquinus, - Pusa, ๗oई"1
Gd $\operatorname{\theta } \theta$.
Hamilton Smith.

Cuvier.

Raffles.

BROW-ANTLERED RUSA.

This species has not been seen south of Maulmain, but it not improbably exists in Tavoy Province, for the Karens say there are two species of rusa, and I have seen on the mountains parts of horns that appear to belong to this species. Mr. Blyth thought, from the accounts furnished him, that this was an undescribed species, but Capt. Phayre told me that he had satisfactorily identified it by its horns with the brow-antlered rusa of $\mathbf{A}$ ssam.
Panolia acuticornis,
Cerveres fiontalis,
Corves lyratus,
Gray : List?
A' Clelland?
Schinz?
$\omega 0 \varepsilon_{n}$

GOAT-A YTELOPE.

The goat-antelope is confined to tise mountins, and was formerly characterized as " a wild sheep, or goat." Capt. Phayre, who first obtained it in Arracan, procured two skulls and skins while here a year or two ago, by paying twenty rupees for them, and sent them to Mr. Blyth, who said they were of the same species as the specimens he had receired from Arracan.

Namorhedus sumatrensis,

Kambing utan,

Antilope sumatrensis,

Cambtan,

Antilope interscapularis
Hamilton Smith.

Marsden.

Pennant, apud Raffles.

Fred. Cuvier.

Lichtenstein, Schinz.

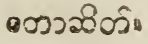


Sheep hare been introduced, but they do not thrive on this Coast. Major Macfarquhar, who formerly owned the only sheep in the province of $T$ avoy, during one rainy season, lost forty out of an hundred and fifty. At Maulmain they appear to do a little better, but the five or six months continued rain must always operate unfavorably to their growth in Further India.

\section{Ovis arics. \\ =\{81 $200 \mathrm{~J} . \quad 30$ \\ GOAT.}

Goats thrive well, and are valuable stock in this country, both for their milk, and for the fiesh of their young kids.

Capra Hircus.

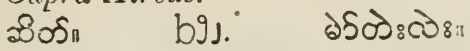

GAUR.

'This is a fine, large animal, with a bison-like appearance, a wild, fierce beast of which the natives are much afraid. It never approaches human habitations, but I once came on a large drove descending the Tenasserim, that had come down to the water for drink. They gazed a minute at the rafts, and then turned rapidly into the jungle.
Bos gaurus.
Ham. Smith.
" gour,
Bison gaurus,
Trail.
Bos aculeatus,
Ham. Smith.
Bison,
Wagler.
Bos (Bibos) cavifrons,
Low. "frontalis,
Hodgson, apud Elliot.
बृिऽ.
osb?ุกำ?
Lambert. apud Gray.
WILD ox.

A wild ox, or wild cow, as it is often called, is frequently seen in large droves all over the uninhabited regions of the Provinces. It bears a considerable resemblance to the gayal in shape, but differs from it in colour, being red 
and white. At a distarice a herd looks very much like a drove of English cattle. Once on coming out of a thick jungle into the open ground, I found myself in the midst of a hundred of them, and they appeared so tame, that my first impression was they were domestic cows; but they soon bounded away like deer, and dissolred the illusion. Mr. Blyth writes me that it is

Bos sondaicus.

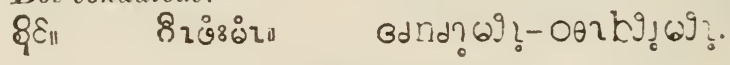

7.EEU OX.

The zebu, or Indian ox, with the large hump on it: shoulders, appears to have been the most usually domesticated ox before the English took possession of the Provinces.

Bos indicus.
รู०8 "
oorb9!.
81ษ்

ENGLISI OX.

Europeans have introduced the English breed of oxen into the Provinces.

Bos taurus.

SIIAN OX.

A small ox from the Shan country is brought down sume times in great numbers, which resembles in its form, the English rather than the Indian ox, but is probably derived from the wild race. Occasionally a young wild ox in the Provinces is domesticated, and brought under the yoke.

\section{Bos sondaicus?}

\section{BUFFALO.}

There are great numbers of wild buffaloes in the jungles, which are supposed by the natives to be indigenous; but they are more probably of the domestic race that have run wild, like the wild horses of America.

There is perhaps no domesticated animal in the world, concerning which learned men, in Furope and America, are so profoundly ignorant, as the buffalo. From misap 
prehension of the character of the animal, they have very generally concluded that the unicorn of the English scriptures was the buffalo. Gesenius, Hengstenburgh, and De Wette, in Germany, render the word by "der Buffel ;" and Stuart, Robinson, and Noyes, in America, say buffalo. "The oriental buffalo," observes one, "appears to be so closely allied to our common ox that, without attentive examination, it might be easily mistaken for a variety of that animal." The Karens say, a sheep is "a kind of a goat ;" and by a parity of reasoning, a buffalo is a kind of an ox; but in no other way. The buffalo, with its black and almost hairless skin, "huge horns," and clumsy body, affords a strong contrast to the red hairy skin, short horns and more elegant appearance of the common ox.

Barnes says, it is "an animal which differs from the American buffalo only in the shape of the horns and the absence of the dewlap." It is well known that the American buffalo is not a buffalo, but a bison, and the two differ from each other much more than either from the common $o x$; and according to modern naturalists, the difference between them is not merely specific, but generic-the buffaloes forming one genus, and the bisons anotlier. According to Swainson, the buffaloes have "a small dewlap on the breast," but they differ from the bisons among other things in having "no hunch on the back," no very "long hair under the jaw and throat," and no mane upon the shoulders. 'The buffalo too, has one pair of ribs less than the bison, and is altogether a widely different animal.

Barnes remarks again of the buffalo, that it "has beer recently domesticated;" but in the laws of Menoo, the great Hindu legislator, who is supposed to have written about the time of David, domesticated buffaloes are often inentioned. It would appear that in his days, they were used to draw carts; for in one place he says: "It a man shall be driving a cart, and his bullocks or buffaloes start and run against a house, he shall not be held in fault. If he run against the steps, let him put up new ones. If he run against the balustrades, let him replace them; there is no 
fine. If the cart shall not run against the house, but the bullocks, the buffaloes, the yoke, or other things belong. ing to the cart, there is no fine, nor if a plough shall run against a house."
Bubalus Arnee,
Bos indicus,
"bubaius,
Hamilton Smith.
Plinius.
Bubalus ferus indicus, Hodgson, apud Gray: List.

"Buffelus, Gray: List.

\section{WHALE TRIBE.}

Two species of Cetacea, animals of the whale family, are found on our coasts.

\section{PORPOISE.}

A species of porpoise is very abundant along our shores, and in the rivers, occasionally, as high as tide-waters reach. It is probably the same porpoise as the one in the Malay waters, for that suecies extends to the Malabar coast.

$$
\begin{aligned}
& \text { Delphinus plumbeus, Dussumier. } \\
& \text { " malayanus, Lesson. } \\
& \text { ऽ઼ิ" }
\end{aligned}
$$

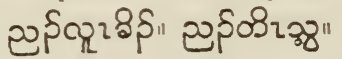

WHALE.

The whale is found south of Mergui, and Capt. Lloyd named a bay a few miles south of the parallel of $12^{\circ} \mathrm{N}$. "Whale Bay"-from the circumstance, he says, "of its being resorted to by numerous whales, and its being the only part of the coast where 1 have seen them."

Balona?

Balanoptera? 


\section{ORNTTHOLOGY.}

"The dodo may possibly be found there-and the casa sowary may perhaps be met with," observed Dr. Pearson in his official charge to Dr. Helfer, when the latter was about to proceed on his scientific mission to these Provinces. The dodo and cassowary were about as probably inhabitants of this Coast, as the phœnix and ostrich; but the remark shows how little was known of our ornithology a dozen years ago. Indeed it remained quite a blank until Mr. Blyth was appointed Curator of the Asiatic Society's Museum. He examined and named the collections made by Helfer and others in these Provinces, and those gathered by Captains Phayre and Abbott in Arracan, so that by far the greater proportion of our birds are now known. Still, there undoubtedly remain many new species to be discovered; for of ten birds that frequented my compound in Maulmain, one proved to be a new species.

\section{PAPACIOUS BIRDS.}

The Raptores, or rapacious birds, are numerously represented in these Provinces. We have about thirty species of vultures, eagles, kites, buzzards, harriers, falcons, hawks, goshawks, fish-hawks, and owls.

chinese vulture.

The Chinese vulture, of a brownish black colour, is of ten seen in great numbers, even in the suburbs of our largest towns.

Vulture leuconotus.

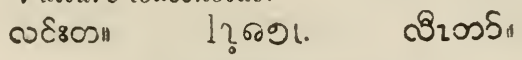

PONDICHERRY VULTURE.

This is called by the natives the red-headed vulture, from the flesh-coloured skin on the sides of its head and neck. It is not so abundant as the preceding species.

Vulture pondicerianus.

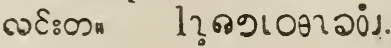

ชిเoรระเร. 
A white vulture with a little black on the wings is de. signated in the Hebrew Scriptures, where gier-eagle is read in the English version; and the word rendered vul. ture in Job, is more correctly translated in Leviticus and Deuteronomy by kite. It was probably a generic term like the Burman zune, ${ }^{*}$ embracing several species of falcorrs and kites. In Persian the kestril is called yuh, no doubt a word of common origin with the Hebrew name ayah.

\section{OSPREY.}

The common osprey, or fisher-eagle, is often seen on the sea-coast. The Karen name of this bird at Tavoy, is, at Maulmain, applied to a large owl.

Pandion haliatus.

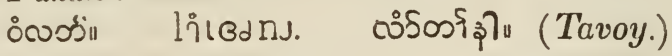

EAGLE.

Eagles are in the interior only, and they soar so high, that they are not often noticed by travellers in the deep forest. The Karens describe two or three different species. One, they call the peacock-eagle, from its habit of selecting peacocks for its prey. 'The Burmese appear to have only one name for three species.

$$
\begin{aligned}
& \text { Aquila bifasciata, }
\end{aligned}
$$

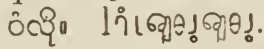

$$
\begin{aligned}
& \text { lาเงอำ. } \\
& \text { lกเงาวม. }
\end{aligned}
$$

KITES.

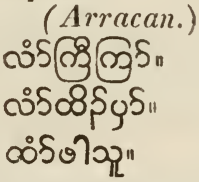

The common Bengal kite abounds in the neighborhood of Maulmain.
Milvus ater, $8 \$ \cup \mathcal{S}_{11}$
liาเ

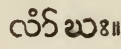
BUZZARDS.

Blyth says that "the smallest species of the true buz" zard" inhabits the "Tenasserim Provinces.

Buteo pygmœus.

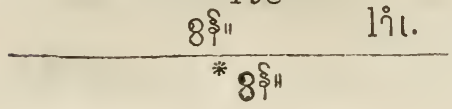

ஸ่ * 
IIARRIER.

A black and white bird of the buzzard tribe, a species of harrier, is not uncommon.

Circus melanolcucos,

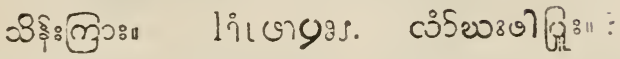

TIIE KESTRIL.

The kestril of Europe is an inhabitant both of these Prorinces and Arracan.

Falco tinninculus.

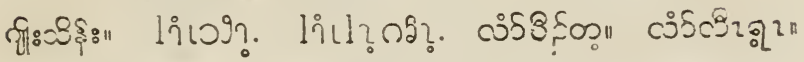
S.MALL FALCON.

A small falcon is found in Arracan, which I have not met with in these Provinces.

Terax Bengalensis.

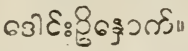

HA W F

A common hawk in Maulmain, of which I sent a specimen to Mr. Blyth, is,

Nisaster badius,

Acripiter Dussumieri.

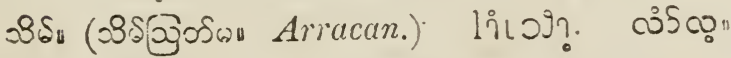

TEESA HAWK.

Mr. O'Riley sent a teesa hawk from Amherst, of which, Mr. Blyth remarked: "It seems to be

Poliornis faciatus, $\quad$ Lord Hay.
"tecsa?"

GOSHAWK.

A crested goshawk was shot by Mr. Barbe at Yay, and doubtlessly exists in other parts of the Provinces.

Astur trivirgatus.

" indicus,

Hodg

" palumbarius,

Jerd. 
FISHER-HAWK.

There are three or four different species of fisher-hawhin the Provinces, but I am unable to distinguish the species. Capt. Phayre found two in Arracan.
Ilalicetus Hacei,
" blagrus,

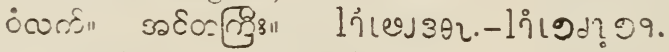

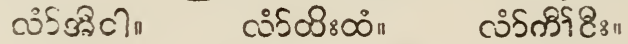
(Arracan.)
66

BRAHMINEE-KITE.

A white headed fish-hawk, which I judge to be the Brahminee-kite of Hindustan, abounds at Tavoy.

IIaliatus pondicerianus.

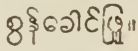
liเ ช2 20ㄱ.
ผำริ์

WIITE-BANDED FALCON.

A small bird of the falcon tribe, with a band of white around its neck, but black on the head and back, is seen in the Taroy forests.

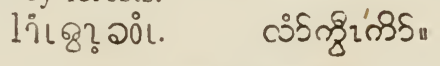

SMALI HAWK.

A diminutive hawk, the smallest of the tribe, grey on the back and white on the head, is common at Tavoy, that the Burmans call doung-sune, a name which in Arracan is given to a large kite, Hœmatornus undulatus, or falco bido; while the small hawk there has a different name.
เวิย
lỉınucois.
cวิรి,

SMALL REDDISH HAWK.

A small hawk of a reddish colour is met with occasionally in the Karen jungles.

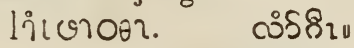

LONG-TAILED HAWK.

$\Lambda$ bird about the size of a crow, resembling a hawk, with bands of white and black on its long tail, is found in the interior.

lำฉด? .

ஸ่ริ8อข3. 
SPARROW-HAWK.

A hawk with a forked tail, like the sparrow-hawk, is not rare.

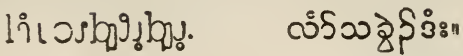

BARN OWL.

The conmon English barn owl is perhaps more abundo ant in thess: Provinces than in Great Britain.

Strix fammea.

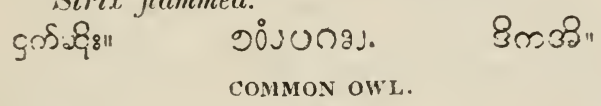

Capt. Abbott furnished Mr. Blyth with an ordinary sized owl from Ramree, of the same genus as the barn owl, which 1 think inhabits these Provinces.

$$
\begin{aligned}
& \text { Strix barlia. }
\end{aligned}
$$

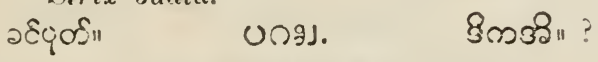

HORNED OWL.

This is a large horned owl which the Karens say is sometimes as large as a hornbill. The cuckoo of Leviticus in ou rEnglish version, is supposed to be a species of horned owl.

\section{Bubo macrocephala.}

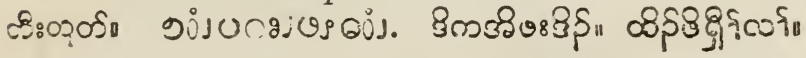

\section{NAKEE-LEGGED OWL.}

A large horned owl, with naked legs, often lifts up its inournful roice at midnight even in towns. Karers call the horned owl, mookaulaing, or the devil, and seem to look upon its large goggle eyes with the same sort of re. serential horror, that the Western Indians do the Virginia horned ow!. Like the ancient Romans too, its appearance in a lown or hamlet is regarded as the harbinger of evil. Nor is this strange, for they send forth such deep muffled sounds as heard in the dark still night, seem like tones from a charnel house.

Ketupa Leschcnaultii,

Strix Hardwickii,

Lesson.

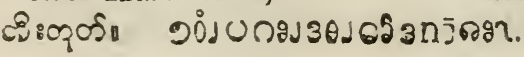

Gray.

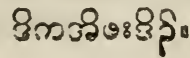


SCOPS OWL.

I sinall owl of the genus scops Mr. Blyth says inhabits Arracan, and, may not improbably be found in these Provinces.

$$
\begin{aligned}
& \text { Scops lettia. } \\
& \text { द्वृळ }
\end{aligned}
$$

ATHENE OWL.

'I'wo different species of small owls, belonging to the genus athene, inhabit the Provinces. The first is of $a$ more uniform rufous colour than the other members of the tribe.

$$
\begin{aligned}
& \text { Athene castanopterus. } \\
& \text { " cuculoides. } \\
& \text { Noctua. }
\end{aligned}
$$

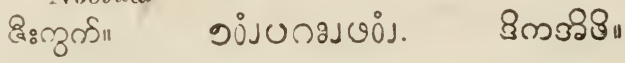

\section{TOOTH-BILIED BIRDS.}

Of the Dentirostres, birds with a notch in the bill, the Provinces furnish numerous species of shrikes, bulbouls, thrushes, babblers, orioles, stonechats, warblers, wagtails, fruit-eaters, fly-catchers, and broad-bills.

\section{WHITE-BELLIED SHRIKE.}

This is a new species of shrike, of which I sent Mr. Blyth his only specimen. Me describes it as "very closely allied to $\not{Z}$. IFardusckii, Vigors; from which it differ31 , in having the entire crown nigrescent, passing gradually from the black of the forehead to dark ashy on the nape; the ear-coverts being uniformly coloured with the feathers superiorly adjacent :-2, in having the rump and upper tail-coverts of the same deep maronne colour as the back and scapularies: -3 , in the much greater development of the ferruginous margins of the great wingcoverts and tertiaries:-and 4, in having the under-parts uniformly white, a little subdued, and tinged with a very faint blush, but having no trace of rufous on the flanks and elsewhere."

$$
\text { Lamius hypoleucos, Blyth. }
$$




\section{RED-HEADED SHRIKE.}

A brown shrike with a reddish head is common throughout the Provinces.

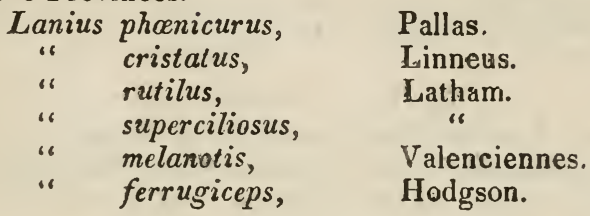

TIGER SHRIKE.

Mr. Blyth mentions the tiger shrike as being found on this Coast.

Lanius tigrinus.

$\begin{array}{ll}\text { " magnirostris, } & \text { Lesson. } \\ \text { strigatus, } & \text { Eyton. }\end{array}$

PEGU SARIKE. Pegu.

Another shrike is described in Belanger's royage from Lanius collurioides.

INDIAN SHRIKE.

This shrike has a black head, and though receired by Mr. Blyth from Arracan only, I think I have seen it in these Provinces.

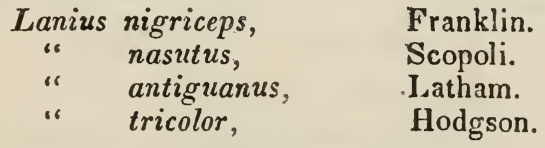

GREY-BACKED SHRIKE.

$\boldsymbol{\Lambda}$ grey shrike is common in Arracan of the same size as the preceding, but differing in colour.
Lanius tephronotus,
" nipalensis,
Vigors.
Hodgson.
RED-BACKED SHRIKE.

A small shrike with a rufous back is also found in Ar racan.
Lanius caniceps, " crythronotus,
Blyth.
Jerdon. 


\section{URONGO SHRIKE.}

A species of drongo shrike inhabits Arracan, and per. haps these Provinces.

Tephrodornis pelvica.

Tenthaca

\section{Hodgson.}

\section{PARADISE EDRLIUS.}

The loud, flute-toned edolius might be termed the Tenasserim nightingale, for it is considered by the Karens as the sweetest singer of their forests, and it seems to delight in cheering them at eventide. There was an old friend that used to come at sunset every evening, and perch upon a guava bough near my dwelling in Dongyan; and there it would sit and pour forth one incessant stream of melody for a half hour at a time. This bird has a glossy, jet black dress, with two remarkably long shafts to its tail-feathers, "broadly barbed on the inner side towards the extremity; the stem however, giving one twist, so that the inner part appears to be the outer one."

Edolius paradiscus.
" retifer,
" cristatcllus,
" intermedius,
Temm.
Blyth.
Lesson.
Dicrurus platurus,
Vieillot.

Cuculus paradiseus,

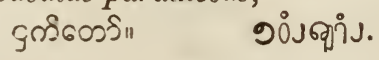

Linn.

MALABAR EDOLIUS.

A second species from the Provinces is thus distinguished: "In this species, the frontal plumes attain a length of two inches and a half, and flow backward over and beyond the occiput. The hackles of the neck are also decidedly more elongated than in the others."

C'hibia malabaroides,

Edolius

IIodgson.
" grandis,
Lanius malabaricus,
Blyth.
Latham, not Sonrerat.

ARRACAN EDOLIUS.

Capt Phayre found another species of edolius in Arra 
can, called by the same Burmese name, which I have not met with in these Provinces. It has the long tail feathers of the preceding species, but the stem takes only half a turn, so that "the barbed tips remain vertical to the axis of the body."
Bhringa remifer,
" tectirostris,
Erolius rangonensis,
Temm.
Hodgson.
Edolius remifer.
Horsfield.

LARGE-CRESTED EDOLIUS.

Mr. Blyth mentions another species from Arracan, distinguished by its crest-feathers attaining to an inch and a half in length.
Edolius grandis
Gould.
"bengalensis,
Hay.

KING crow.

The king crow is a small black bird, resembling the preceding, but without the tail feathers. It derives its English name from its bravery in chasing away the crows. Both the Burmese and Karens often call the edolius by the same name that they do this bird. A specimen that I sent Mr. Blyth, he wrote was
Dicrurus macrocercus.
Vieillot.

" indicus,
" forficatus,
" fingah,
balicassius,
Hodg. Stevens.
Bhuchanga albirictus,
Horsfield.
Blyth.
Sykes, Jerdon. çก์ธcoरu อง่งการชา.

SMALI KING CROW.

There is also a smaller species of king crow in the Provinces.

Dicrurus intermedius, Blyth.

ARRACAN KING CROW.

Arracan has another king crow with "its outermost tail feathers very much twisted over, forming a singular orrament." 
Edolius barbatus

Chilia hottentota, " casia,

Corvus hottentotus,

Edolius crishna, Criniger splendens,
Gray. Hodg.

Linn.

Gould.

Tickel!.

\section{ROSY-IIED BIRD.}

The nale red bird is a beautiful little creature, with a black head, and is usually seen in company with the female, which has yellow on her feaihers wherever the male has red.

Pericrocotus roseus,

Phanicornis "

Muscicapa

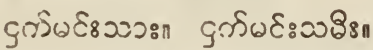
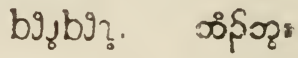

PINK-EAREL BULBOUL.

Bulbouls, so uften celebrated in Persian and Hindu poetry, are numerous on this Coast. 'The pink-eared bulboul is one of the most common birds in the Provinces, especially in the neighborhood of 'Tavoy. It is crested like the American cedar bird, which it resembles in habit, for it is an inveterate fruit eater, but has a little crimson tuft orer the eye, from which it derives its specific name. Large fincks tenant the shrubbery in the suburbs of Tavoy, and may be seen coming into town early every morning in little armies: and whatever garden cortains a berry-bearing tree, is sure to be the residence throughout many hours of the day of a few pink-eared bulbouls.

Pycnonotus* jocosus.

Gracula cristata,

Lanius cmeria,

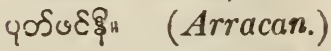

Scopoli.

Shaw.

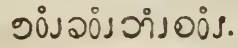

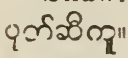

(Tavoy.)

"This genus includes Swainson's Hamatornis. 


\section{BLACK-EARRD BULBOUL.}

There is another bulboul here with the head wholly black, but crimson under the tail, like the preceding species. The natives do not distinguish them.

Pycnonotus atricapillus?

\section{YELLOW AND GREEN BULBOUL.}

This is a very common bird in Maulmain, and in the dry season its musical, though little varied notes, are often heard. It is rarely seen in Tavoy.

Pycnonotus Finlaysoni.

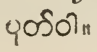

gơsb? 000 s.

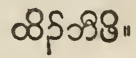

YELLOW BULBOUL.

The yellow bulboul differs very slightly in its general ap. pearance from the preceding. Mr. Blyth received it from Arracan, but $I$ believe it also frequents our groves.

Pycnonotus flavescens.
QSOी०

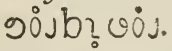
कిริ8:

BROWN-BREASTES BULBBOUL.

A bulboul, nearly related to the pink-eared species, but with a brown breast, inhabits the Provinces.

Pycnonotus nigropileus, Blytl.

AMHERST BULBOUL.

A bulboul, from Amherst, is said to be a representative of the Arracan

Pycnonotus hemorrhous.

BLACK-CRESTED BULBOUL.

Another bulboul has a black-crested head with a yellow body, found in Arracan by Capt. Phayre.

Pycnonotus melanocephalus.

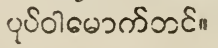

GREEN BULBOUL,

Three different species of green lbulbouls are desribed from Arracan, one or more of which $I$ have notice 
in these Provinces. They are green, with a little blue on the breast, and wing.

Phyllornis* cochinchinensis.

nalabaricus.

Phyllornis aurifrons.

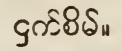

Phyllornis Hardwickii.

Chloropsis curvirostus, Swainson.

$\begin{array}{lll}\text { " cyanoptcrus, } & \text { Hodgson. } \\ \text { " chryso-gaster, } & \text { Horsfield. } \\ \text { auriventris, } & \text { Gmelin. }\end{array}$

ใॄ:

BLACK-HEADED BELBOUL.

This bird has a black but crestless head, with a yellow body, common in Arracan.

Brachypodius mclanocephalus,

Turdoides atriceps,

Gmelin.

T'emminck. QS०ी"

ochre-heAided bULboul.

The ochre-headed bulbul is occasionaliy seen in these Provinces, and Mr Blyth remarks that it is "a favorite cage bird with the Malays."

Criniger ochrocephalu:,

Tricophorus crispiceps, Gmelin. Blyth.

YELLOW-BELLIED BELBOCL.

Another bulboul is mentioned from Arracan, allied to a yellow bellied African species.

Criniger flavcolus.

CROWN-FEATIER-POINTED BULEOUL.

This also is an Arracan bulboul that may be found on this Coast.

Hypsipetes psaroides.

BLACK BULBOUL.

A bulboul with a black head and back resembling the preceding species inhabits the Provinces. "It resembles," says Blyth, $\boldsymbol{H}$. psaroides and $\boldsymbol{H}$. nilgiriensis ; but is 
altogether blacker, the black of the crown forming thus no contrast with that of the rest of the upper-parts : lowerparts, and rump dusk-cinereous, and slight edgings of the same to the alars and caudals : upper tail-coverts black." Hypsipetes

Blyth.

ASHY BULBOUL.

Another bulboul from Arracan is of an ash colour.

Hemixas flavala, Blyth.

RED-HEADED BULBOUL.

This is a small ferruginous bird of Arracan, that Mr. Blyth appends to the bulbouls, but of an uncertain group. Heteromorpha ruficeps.

BLUE ANT-THRUSH.

As in England and America, the thrushes of India are anong the sweetest songsters. Two distinct species of blue ant-thrush enliven the woods and dales of Tenasserim, and a third is found in Arracan. Our ant thrushes are splendid green birds, with crimson crowns and blue manties, with sometimes shades of green on the breast.

Pitta Malacceusis.

Brachyurus cyanopterus,

Temm.

Pitta cyanea.

Paludciola nipalensis, (Arracan) Hodg

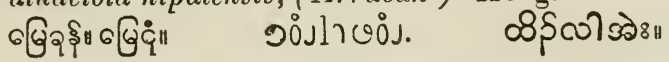

GREEN AND RED ANT-I HRUSH.

This is a fine little bird with scarlet wings, and a green robe, but when exposed to the light, Mr. Blyth says the green turns to blue, and the red to a dull ash colour, and that "it combines in its manners the traits of the jay and shrike."

\section{Cissa* venatorius.}

\section{THRUSH.}

A thrush with " upper parts greenish olive-brown," and white on the belly, is found from Arracan to the straits of Malacca.

$$
\begin{array}{cl}
\text { Turdus rufulus, } & \text { Drapier. } \\
\text { modestus, } & \text { Eyton. }
\end{array}
$$


OLIVE THRUSH.

A thrush with upper parts dull olive, and under parts light rufescent, is described from Arracan.

Geocichla citrina,

Turdus Macei,

" lividus,

" rubecula,
Lath.

Vieillot.

'Tickell.

Horsfield.

\section{ZOOTIIERA THRUSH.}

Specimens of this thrush have been furnished from Arracan. It has a large bill, olive-brown in its whole upper parts, with an intermixture of white on the under parts. "The plumage of the nestling much resembles the garb of an English blackbird."

Zoothera marginata.

BLACK THRUSH.

Dr. Griffith met with a thrush north of Ava, with the back slaty-black, breast deep black, and belly dull white. Mcrula levicogaster.

\section{R()CIE-THRUSI.}

A species of rock-thrush, blue with rufous on the lower parts, is common both in these Provinces and in Arracan. The natives do not appear to distinguish it from the antthrush.

Petrocincla affinis.

BA RBLER.

A small bird, remarkable for its chattering, is often seen in flocks near Taroy. It belongs to the babblers.

Garrulax Bclangeri.

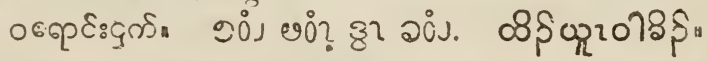

Two other species of babblers have heen found in $\mathrm{Ar}^{*}$ racall.

Garrulax, leucolophos.

" moniligcr.

\footnotetext{
- Craferopus, Irnthocincla, Circlosome,

Swainson.

Gould.

Vigors, Hodgson in part:
} 
BAPDLESS BABBLER.

Another species of babbler inhabits the Provinces, that is "remarkable" "for the very slight development of the black, pectoral band, which in one is indeed wanting altogether."

Garrulax pectoralis

AEBOTT'S BABELLR.

This bird was found by Capt. Abbott in Arracan, and being regarded by $M r$. Blyth as the type of a new genus related to the babblers, he named it

Malacocincla Abbolti.

IORA B ABBI.ER.

Another Arracan bird belonging to the genus iora is classed with the babblers.

Iora typhia.

Ilotacilla typhia. Linnn.

FAN-TAILED BABBLER.

A pretty bird, with a fan-tail, related to the babblers, is very common in the province of Tavoy.

Pomatorlinus olivaceous.

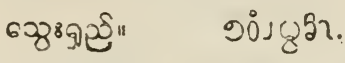

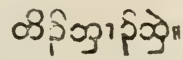

PHAYRE'S POMATORHINUS.

T'here is another species of pomatorhinus in Arracan, having the crown of the same olivaceous hue as the rest of the upper-parts, this being of a greener tinge than in the Darjeeling birds; the feathers above the lores short and white, like the rest of the supercilium; and the rufous of the under-parts is much weaker and more fulrescent."

\section{Pomatorlinus Phayrei.}

TIMALIA BABBLER.

A babbler belonging to the genus timalia, is an inhabitant of the Provinces.

Timalia gularis 


\section{MANGO BIR.D.}

The mango bird, or black-headed oriole, famous in Indian poesy, is one of the most numerous of Tenasserim songsters ; it comes to our gardens at early dawn, when its rich mellow notes are heard pealing far through the mango bowers. It is a large yellow bird, with a black head, easily recognized.

Oriolus melanocephalus.

çกิ่าน

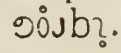

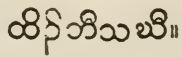

INDIAN ORIOLE.

This is another mango bird, found in the Provinces, differing slightly from the preceding, and for which the natives have no name to distinguish it from the other, though they are aware of the existence of the two species. Oriolus indicus.

IRENA.

The irena is a bird of the oriole tribe, an inhabitant of Arracan, with a black breast and blue back.

Irena puella.

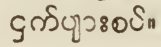

STONECHAT.

A species of stonechat tenants the jungles of Arracan, and is probably in these Provinces; but $I$ am not quite certain that I have identified it.

Saxicnla caprata.

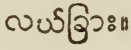

WHITE-F,YED WAREI,ER.

A small bird which Mr. Blyth refers to the honey-suckers, but which Swainson calls the white-eyed warbler, inhabits our jungles.

Zosterops palpebrosus.

TAILOR BIRD.

Tailor birds are very common at Tavoy, though rare at Maulmain; and they frequently adorned my garden with their curious pendulous nests. One, selected the living 
leaves of the mulberry tree, which it sewed very cleverly; another, the large leaves of a Malay apple tree, and both sewed their nests in sheltered recesses, where they were in a great measure shielded from the rains.

Orthotomus longicaudata.

Motacilla

Gmelin.

" sutoria.

Orthotomus sphenurus, Sylvia ruficappilla,

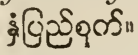

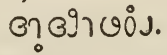

Swainson.

Hulton.

WARBLER.

A small bird belonging to the warblers, with the general form of the tailor bird, is very common in Tavoy shrub. bery, but is seldom seen in Amherst Province. It has the same native name as the tailor bird, and is probably one of the six species of phylloscopus which have been dis* covered in Arracan.
Phylloscopus fuscatus,

"magnirostris,
javanicus,
viridanus,
" $\quad$ brunneus,
" $\quad$ modisticeps,
modestus,
Blyth.
Horsf.
66
66
Hodgson.
Gould.

ETHERIAL WARBLER.

Mr. Blyth mentions this bird as inhabiting the Tenasserim Provinces. He says it is " the etherial warbler of Latham, and the female agrees with the supposed female of his blue Indian warbler.
Cyornis rubeculoides,
Niltava brevipes,

Blyth.

ARRACAN CREEPER.

Two small birds from Arracan are by some considered as belonging to genera which Mr. Hodgson associates with the creepers.

Stachyris chrysaa,

Erpornis zantholeuca,

Hodgson. 
WAGTAIL.

A species of wagtail is often seen in company with cattle, "following them and gathering the insects that are beaten up by the beasts' foot." It is common in the Provinces, though I am not certain of the species, but the one Capt. Phayre found in Arracan was

Budytes leuma.

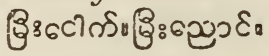

WATRR-WA GTAIL.

A water-wagtail bearing considerable resemblance to the European bird, is abundant in the neighborhood of Maulmain. It heralds in the dry season, always leaving the Coast in the rains, and returning again at their close. Motacilla luzonicnsis.

vososgrus.

$$
\text { รั่ง อาง อำ. }
$$

क 855 పे,

\section{ENICURUS.}

Capt. Phayre met with two species of enicurus in $\mathbf{A r}$ racan, birds belonging to the wagtail family; and one oth. er species is found in these Provinces.

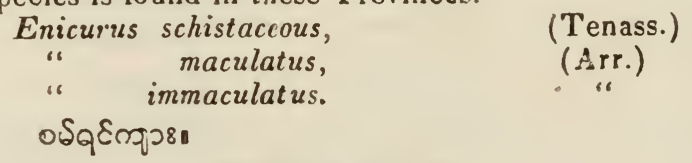

TREE PIPIT.

A bira has been described from these Provinces whose habits approach those of the tree pipits, but it is also related to the wagtails.

Ncmoricola indica.

Motacilla.

๑.sus.

(Arracan.)

RICHARD'S PIPIT.

This is a small bird found in Arracan, identical with a pipit occasionally seen in England.

Corydalla,* Richardi.

Anthus, 
SLENDER LARK.

This bird is called the slender lark by Latham, but is classed with the pipits by Blyth, who says it is found in the countries eastward of the Bay of Bengal, down to the Straits of Malacca.

\section{Corydalla rufula. Anthus rufulus.

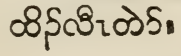

BROWN=WINGEU CHATTERER.

A bird belonging to the group of chatterers, with brown wings, has been described from the Provinces.

Soropus nipalensis.

Siva

PARADISE FLY-CATCHER.

This is a handsome, crested, black-headed bird, with chestnut back and wings, and a very long tail of the same colour, a few of the tail feathers being prolonged much beyond the others. It is quite common throughout the Provinces, but is rarely seen in the neighborhood of large towns.

\section{Muscicapa paradisi.

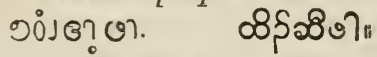

PURPLE FLY-CATCHER.

A purple fly-catcher was found by Capt. Phayre in Aro racan.

Muscicapa cœrulea.

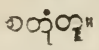

SMALL FLY-CA'TCHER.

A smaller fly-catcher was also discovered in Arracan.

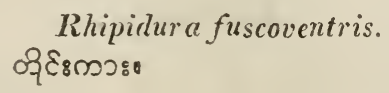

FLY-CATCHER.

Mr. Blyth mentions a fly-catcher from Arracan which ke called

Muscicapula melanoleuca. 


\section{BROAD-BILL.}

Four species of manakins, or broad bills, birds with short and excessively broad bill, inhabit the Provinces; and Capt. Phayre met with a fifth species in Arracan.

Eurylaimus javanicus.

Cymbirhynchos nasufus.

Serilophus lunatus.

affinis, (Arracan.)

Corydon sumatranus.

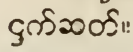

(Arracan.)

\section{CONIC-BILLED BIRDS.}

The Conirostres, or conic-billed birds, form a numer ous class of crows, pies, mỳnahs, starlings, finches, sparrows, buntings, larks, and hornbills.

\section{Crow.}

Three different crows are seen on the east side of the Bay of Bengal, and all differ from the common Europearr and American crows. The "common India crow, sometimes mistaken for the jackdaw," is seen from Calcutta to Akyab ; southward throügh the Provinces to Malacca, the " common India black crow, nften erroneously term. ed raven," abounds ; and in the Straits of Malacca, and think in the Karen forests, the large-billed crow is com. mon.

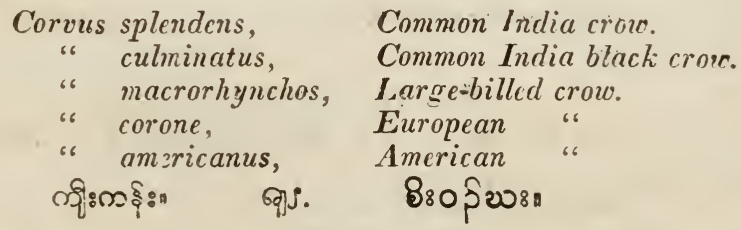

BLCF، MAGPIE.

Mr Blyth had a species of blue magpie, which he says inhabits the mountains between Arracan and Pegu.

Psilorhinus magnirostris,

Blyth.

Pica,

Vigors and Gmelin. 
WANDER:NG PIE.

This is a handsome bird with a long tail, the feathers of which are tipped with black, while the back is of a cinnamon colour. The Karens call it the tiger-king crow, hut naturalists class it with the wattle crows, and Wagler places it in the same genus as the magpie.

Crypsirina vagabunda.

Coracias

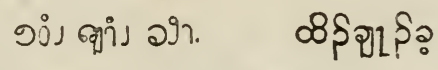

THE SATIN CROW, OR BENTEOT.

The benteot is a species of the same genus as the preceding, and has the same vernacular names. Mr. Blyth wrote of a specimen that I sent him: "A bird which I have only seen from Tenasserim and Java-never from the Malay Peninsula." It is quite common in the neighborhood of Maulmain and its rarity in India makes it worthy of special attention to collectors.

\section{Crypsirina* varians, Vieillot. \\ Phrenotrix temia, Hors.

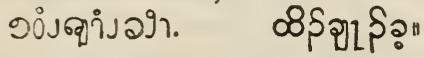

TALKING MYNAH.

This is the black mynah, with a yellow head-band, so often seen in cages in this country, and which learns to talk as readily as a parrot.

$$
\begin{aligned}
& \text { Gracula religrosa. } \\
& \text { woc8mo. } \\
& \text { รỏงlราb ถร. }
\end{aligned}
$$

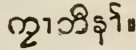

PIE.D SEARLING.

The pied starling abounds in the compounds and fields of 'Tavoy, and is often sten perched upon the back of the buffalo gathering insects.

Sturnus contra.

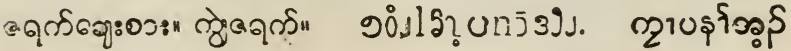

\section{SUB-CRESTED MYNAH.}

This mynah is as numerous at Maulmain as the pied at arling at Tavoy. They build their nests in the hollows 
of trees near human habitations, and their clear full notes are constantly heard in our compounds.

Acridotheres cristatellus, Blyth.

Gracula cristatella. Lin.

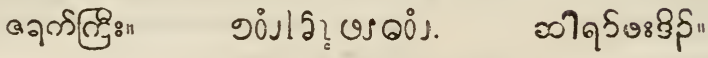

WHTE-HEADED MYNAH.

Another common mynah at Maulmain of which I sent a specimen to the Asiatic Society's museum is

Sturnia malabarica, Blyth.

Pastor malab:ricus, Jerdon.

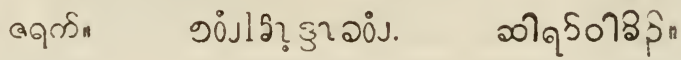

BI.ACK MYNAII.

A species of black mynah is occasionally seen in the in terior.

$$
\begin{aligned}
& \text { Pastor tristis? } \\
& \text { बapर: } \\
& \text { วังเราวง? } \\
& \text { कर กิ? }
\end{aligned}
$$

B.NK MYNAH.

The bank mynah, a species that builds its nests on the banks of streams, is said to be an inhabitant of the Tenasserim Provinces.

Acridotheres ginginianus.

Turdus

Latham.

CRESTED MYNAH.

This mynah is distinguished by a small crest, but it is not common in these Provinces.
Acridotheres grissus,
Horsfield.
Pastor rristalloides,
Hodgs.

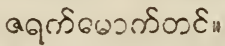

YELLOW-BARRED MYNAII.

Mr. Barbe found a pretty mynah in the Yay forests, with a yellow neck, and yellow bars on the feathers. Ampeliceps coronatus. 


\section{CALORNIS MYNAII.}

Mr. Blyth describes a species of mynah from this Coast belonging to the genus calornis; and mentions another starling.

\section{Calornis cantor.}

Sterna poliocerca.

YELLOW-CAPPED WEAVER BIRD.

A small finch or sparrow, with a yellow head, is very common in Tavoy. It is remarkable for building pensile nests, suspended to the branches of trees. The tall mango trees are usually selected, but I have had their nests in my garden on citron trees.

Euplectes Philipensis.

๑ว

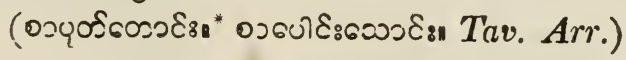

BLACK-HEADED FINCH.

A blacked headed finch belonging to Swainson's genus amadina is found both in these Provinces and Arracan.

Munia rubroniger.

CHINESE STARROW.

A species of amadina, or grosbeak, called the Chinesesparrow, is mentioned as an inhabitant of Arracan.

Amadina Sinensis.

FIELD SPARROW.

A snall bird sometimes called a field sparrow, is not uncommun.

Amadina striata.

Loxia stria's,

Fringilla leuconota,

Latham.

Temm.

INDIAN SPARROW.

'The common sparrow of the Provinces so nearly resembles the European sparrow, that Mr. Blyth originally considered it the same, but he has latterly allowed it to be a distinct species.

Passert indicus.

* प्री is a Tavoyism here, and on pages 260-262 for the Burman gof f Pyrgita. Swairson. 


\section{MOUNTAIN SPARROW.}

This is another European sparrow which Capt. Abbotk found on the Island of Ramree. It is the common sparrow in Chusan.

\section{Passer montanus.}

YELLOW SPARROW.

A yellowish sparrow found in Arracan, is described as

$$
\text { Passer flaveolus. }
$$

BUNTING.

A bunting, or ortalan, inhabits the Propinces. "It differs from Eu. aureola of Siberia in having no black on the chin and throat, in the well defined yellow supercilium, and in having the ear-coverts intermixed with yellow or grey."

Euspisa flavogularis,
Emberiza aurcola.

Blyth.

\section{SKY LARK.}

Mir. Blyth decribes a lark from Arracan which he says "Very closely resembles the British sky lark in its song and habits." If such a bird inhabits these Province it has quite escaped my notice.

Alauda gulgula.

CONCAVE HORNBILL.

Thic hornbills are among the most remarkable birds of India. Their flight is elevated and rapid, and the sound of their wings as they sweep through the air is like the rush of an approaching tempest. There are four specie: on these Provinces, all with bills of an enormous size, and nne with a high concave cask. 'These birds are celebrated in Karen poetry for their conjugal affection. 'Their nests are constructed in a superior manner of clay in the stumps or hollows of old trees. After the female has layed five or six eggs, the male bird shuts her entirely in with mud, except a small orifice where she can only peep out her head. Here she must sit during her incubation, for if she breaks through the inclosure her life pays the forfeit; but to compensate for the loss of freedom, her 
spirited mate is ever on the alert to gratify his dainty mistress, who compels him to bring all her viands unbroken, for if a fig or any fruit be injured, she will not touch it.

Buceros cavatus.

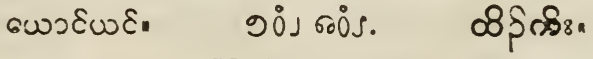

BLACK HORNBILL.

This species from its colour is called by the natives the black hornbill.

Buceros pusaran.

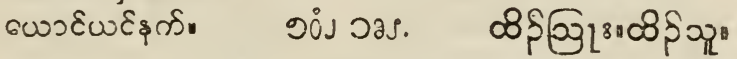

S.M ALL HORNBILL.

'T'wo other species are considerably smaller than the preceding.

Buceros albirostris.

"plicatus.

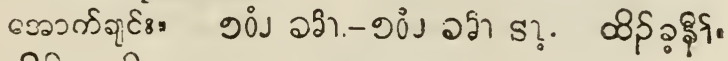

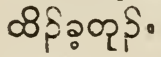

\section{CLIMBING BIRDS.}

The Scansores, or climbing birds, embrace in these Provinces parrakeets, Jorikeets, woodpeckers, barbets, creepers, nuthatches, and cuckoos.

\section{hlack-billed parrakeet.*}

Immense flocks of parrakeets may be seen simultanenusly descending upon the rice fields, where persons have to be in constant attendance to drive them away during the season of harvest. The bill of the female is black; and the natives say, always continues so; but Mr. Blyth remarks : "In a presumed female obserred in cap. tivity, the upper mandible changed from black to coral red, when the bird was about eighteen months old."
Palcornis barbatus,
"
Swainson.

Psittacus

gondicerianus,
borneus,

Gmelin.

- The generic native names for a!l the parrakeets are
तुर्रor:as:
эjงซู่ง
ه 
I'sittacus bimaculatus,

" javanicus,

"Osbeckii,

" mystaceus

Palannis nigrirostris,

“6

pooven
Sparrmar.

Osbeck.

Latham.

Shaw.

Hodgson

Fraser (female.)

(female.)

soos.

BENGALEE PARRAKEET.

This species is mentinned as inhabiting the Provinces, but I have not identified it. I think it is included under the same native names as the black-billed parrakeet.

Palaornis cyanocephalus.

Psittacus

" flavitorquis,

Palcornis flavicollaris,

Psittaca bengalensis

Psitiacus erythrocephalus,

"6

"rhodocephalus

"narcissus,

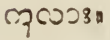

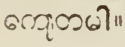

$\left.\begin{array}{l}\text { Shaw. } \\ \text { Kuhl. } \\ \text { Franklin. }\end{array}\right\}$ the female.

Brisscn.

Gmelin.

Latham.

Shaw.

Latham.

\section{ROSE-WINGED PARRAKEET.}

Another parrakeet that comes in smaller companies. which has not the habit of simultaneous descent is ofter seen in the rice fields.

Palaornis torquatus,

Psittaca torquata,

Blyth.

Psittacus Alexandri,

Brison.

" cubicularis,

Latham, var. B.

" docilis,

" steptophorus,

Sulphur Parrakeet, Vieillot.

Desmarest.

Shaw.

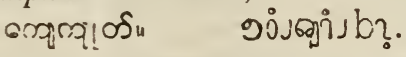

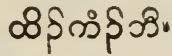

ALEXANDRINE PARRAKEET.

This soldier-like parrakeet with scarlet epaulettes, is found in Provinces Amherst, Pegu, and Arracan, but I 
never saw it in Tavoy or Mergui. It is the bird that was sent to Alexander from Ceylon; and hence its specific name. Some critics think that parrots were shipped by Solomon's fleet rather than peacocks; but ther appear to have been unknown in Europe till the days of Alexander, which would hardly have been the case, had Solomon introduced them into Judea seven centuries he. fore.

Paloornis Alexandrinus.

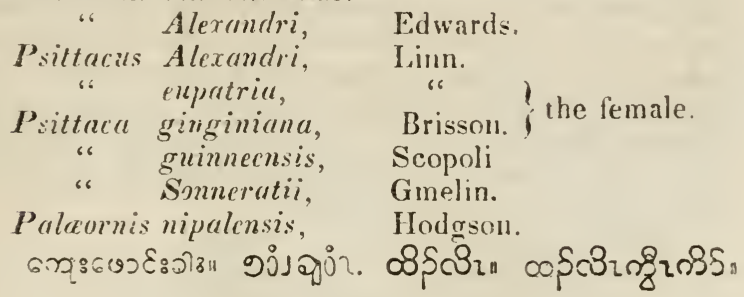

RED-RUMPT LORIKEET.

This is one of the smallest birds of the parrot tribe, with a green body and a red rump. Its child-like notes are ainong the most familiar sounds in the interior during the declining day. Its Burman name signifies " headlong," from its habit of suspending itself from the tree, head-fure. most like a bat.

Loriculus vernalis.

Psittreus

$$
\begin{aligned}
& \text { " gulgulus, Horsfield. }
\end{aligned}
$$

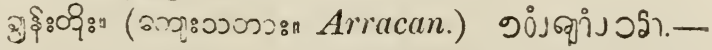

$$
\begin{aligned}
& \text { 6ई }
\end{aligned}
$$

GREEN WOODPECKER.

$\Lambda$ large green woodpecker that inhabits the Provinces, is described as having "the neck, breast, and under-parts very deeply tinged with green, ear-coverts grey."
Pirus (Gecinus) viridanus, Blyth.
" rimirliatus,
Temm.
"affinis,
Raffles.
อำงตุงกำ. 
BLACK-CROWNED GREEN WOODPECKEL.

Another species of green woodpecker is seen on this Coast, of which Mr. Blyth writes: "This species is about ten or eleven inches in length, dusky-green above, with a shade of yellow on the lower part of the back ; cinereous or slightly ferruginous below, mixed with brown on the abdomen. Quill-feathers brown, spotted with white. 'l'ailfeathers brown, pointed as usual in this genus; the two uppermost with a few light-coloured spots along their inner margin. A gray patch encircles the eyes, bounded below by a black stripe mixed with white spots, which runs from behind the lower mandible. In the male the crown of the head is red, often rariegated with black, each feather being black at the base and red at the tip; in the female it is entirely black.
Picus ocipitalis,
" barbatus,
Vigors.
Gray.

ARRACAN GREEN WOODPECKER.

Both the preceding species are found in Arracan, and also a third.
Picus flarinucha, " flavigula,
Gould.
Hodgson.

BLACK WUODPECKER.

'I'here are numerous woodpeckers in the Provinces, among which a black species is very abundant.

Picus (Neiglyptes) jugularis.

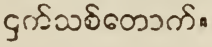

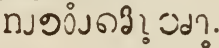

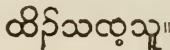

RUFOLS INDIAN WOODPECKER.

This species is known to be a native of Arracan, and I thiuk I have seen it in these Provinces. The fourtht oe is small.

Picus (Micropternus) phaoceps, Blyth.
“" rufus,

BLACK·BELLIED WOODPECKER.

A woodpecker with the "lower-parts black, the feathers laterally edged with dingy golden-fulvous," has recently been described as a new species, belonging to the pied section of the genus.

Picus (Dendrocopus) atratus. 
RED-PLUMED WOODPECKER.

A black backed woodpecker, the male distinguished by a crimson tuft on the head, is a numerous species in the Provinces. It differs very slightly, Mr. Blyth says; from the Molucca woodpecker, I'. Moluccensis.

Picus (Dendrocopus) canicapillus.

OCHRACEOUS WOODPECHER.

An ochraceous woodpecker is mentioned as inhabiting Arracan.

Picus (Microcolaptes) ochraceus.

THKEE-TOED WOODPECKER.

A species of woodpecker with three toes, instead of the ordinary number four, is found in the Provinces.
Picus
('Tiga) intermedius,
Blyth.

\section{INDIAN BARBET.}

Nearly every garden in Maulmain is rocal with the monotone of the Indialn barbet, which the Burmese call "the smith," and the Katens the "gong-ringer." It is a beautiful bird, clothed in green, crimson, and yellow; and is quite familiar.

Bucco indic?s.

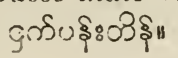

$$
\text { 90J } 00 \text { L } 68 \text { ?. }
$$

o $35882 n$

GRE BN BARBET.

Another barbet resembling the above, but with more green in its colouring, is also common in the neighbor hood of Maulmain: and these are all the barbets I have noticed; though Dr. Helfer said there were five different species of barbet on the Coast; in which event three more remain to be identified.

Bucco lineatus.

母ุะ $\cos \nu \varepsilon_{\text {" }}$

9jง ชำ 121.

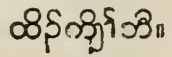

ASIATIC IARBE'T.

$\mathrm{A}$ barbet with a blue breast is found in Arracan, but I have not met with it in these Provinces.

Bucco asiaticus

Trogon

Shaw.

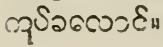


RED-CHEEKED BARBET.

A barbet with three crimson spots on the face, which I have not noticed here, is found in Arracan.

Bucco trimaculatus.

gisuos.

NUTHA'TCH.

A nuthatch with a blue back, a black forehead, and brown under parts, is not uncommon in the suburbs of N aulmain.

Dendrophila frontalis,

Swaill.

Sitta

Horsfield.

ORIENTAL CUCKOO.

A black cuckoo, but of a different genus from the European bird, is seen both in these Provinces and Arracan.

Eudynamys orientalis.

Cuculus orientalis, Linn.

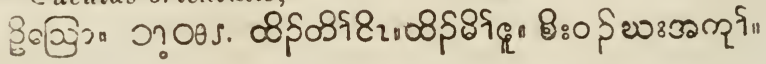
KING-CROW CUCKOO.

A cuckoo resembling the king-crow, and another spe. cies with a slender bill and rufous abdomen, are mentioned as belonging to these Provinces.

C'uculus dicruroides.

" tenuirostris.

מOTTLE-GREEN CLCKOO.

A large bottle-green hird with a long tail, of the cuckon tribe, is not uncommon.

Zanclostomus tristis.

Melias

is

Lessoll.

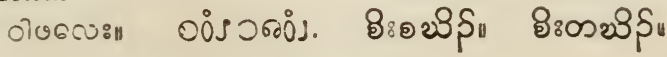

SMALL GREEN CUCKOO.

Capt. Phayre met with a smaller species than the pre= ceding, but of the same form and colouring in Arracan.

Zanclostoma sumatranus.

Melias Diardi,

Lesson.

Cuculus sumatranus,

Raffles. 
AMETHYSTINE-PURPLE CUCKOO.

This attractive little bird is a beautiful specimen of the cuckoo tribe, distributed over some parts of our woodlands.

Chrysococcyx zanthorhynchos, Horsf.

Iampromorpha amethystina, Vigors.

Mr. Blyth had another species of the same genus from Arracan.

Chrysococcyx lucidus.

CROW-PHEASANT.

A large brown bird, which Europeans call " crow-phea" sant," is often seen in Tavoy gardens, and belongs to the cuckoo tribe. The natives say that it lifts up its hoarse voice only when the tide is turning.

Centropus Phillipensis,

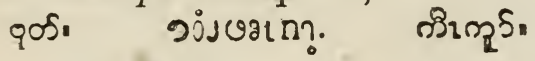

SUCTORIAL BIRDS.

The Tenuirostres, or suctorial birds, are represented in the Provinces by honey-suckers, sun birds, and noopoes.

HONEY-SUCKER.

A honey-sucker, a small bird with a long bill, yellow and olive green back, is often seen in our gardens. It corresponds very nearly to Blyth's description of

Arachnothera inornata,

Certhia afiris,

" longirostris, Jerdon.

Temm.

Horsfield.

Jerdon.

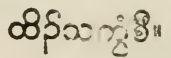

GOALPARA SUN-BIRD.

We have several species of sun-birds on our Coast resembling the humming birds of America, for which they are sometimes mistaken. Their gorgeous plumage may be often seen glistening in the sun as they drink upon the wing the nectar of the flowers. The goalpara is one of the largest of the class, and is sometimes called the Goalpara creeper. It is an elegant little creature, with a brilliant carmine breast and neck, and a splendid cap of dark shining green. 
Nectarinia goalpariensis, Jardine:

Certhia Royle.

Cinnyris Vigorsii,

Nectarinia Scheria (?), Tickell.

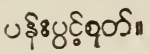
รว่งวชำใด?.

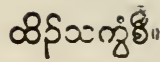

\section{OLIVE-GREEN SUN BIRD.}

The most abundant sun bird in the Tenasserim Prot rinces is perhaps this species; which Mr. Blyth describes thus : "Colour of the upper-parts dull olive-green, brightening a little on the rump: beneath, moderately bright king's yellow; and the axillary tuft intense yellow with flame-colour anteriorly: throat and front of the neck very dark glossy purple, margined laterally and at the gorget with bright steel-purple, below which is a trace of a narrow band of dark red."

Ncctarinia jugularis,

Vieillot.

" flammaxillaris, Blyth.

\section{STRAIGHT-BILLED SUN BIRD.}

Another of our common sun birds has a straighter and shorter bill than the preceding.

Anthreptes phonicotis.

\section{RED-BACKED SUN BIRD.}

A small black sun bird with a brilliant scarlet back is another of our gaudy little visitors.

Dicceum erythronotum.

\section{OTHER SUN BIRDS.}

There are other species both in these Provinces and Arracan.

Dicoum cantillans.

Nectarinia asiatica,

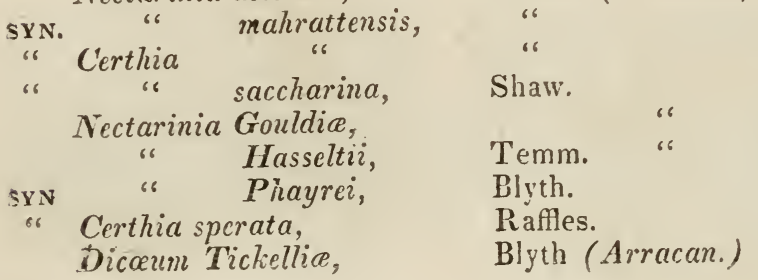


ऽ. Dicaum minimum,

"Nectarinia minima,

"Certhia erythrorhyncha,
Blyth.

Tickell.

Latham.

HOOPOE.

The hoopoe is one of the few birds that we have in common with Europe, and which was well known to the ancients. According to Grecian mythology, Tereus, king of Thrace, was turned into a hoopoe, hoopoes having beer first seen on his monument; and in some parts of Europe it is regarded as a bird of omen. It is the lapwing of Leviticus and Deuteronomy, in our received version. On this Coast, as in other parts of the world, it appears to be a bird of passage, for not one is seen in the rains, although during the dry season, they show their arched, buff-coloured crests in almost every garden in Maulmain.

Upupa epops.

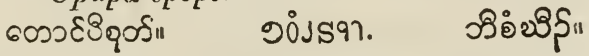

\section{WIDE-MOUTHED BIRDS.}

The Fissirostres, birds with a wide gape, embrace several species of bee-eaters, rollers, kingfishers, trogons, nighijars, swallows, swifts, and swiftlets.

\section{GREEN BEE-EATER.}

The green bee-eater, a very handsome bird, is common all over the Provinces. The Karens call it the Mount Meru bird, because it is supposed to dwell there during the rainy season.

Mcrcps viridis.

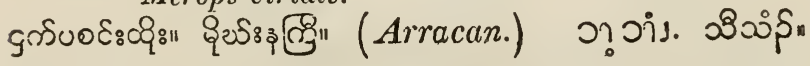

LARGE BEE-EATER,

In Arracan there is a larger bee-eater.

Alcemerops Athertonii.

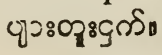

ROLLER.

The roller, often by a misnomer called the blue jay, is diffused over all our compounds. The Burmese say that the most precious sapphire is exactly the colour of the 
wings of this bird; and it is hence called the "roller sap. phire."

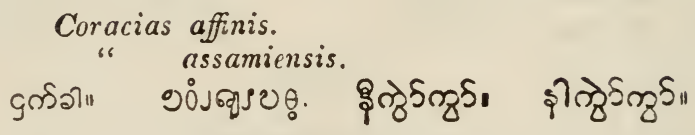

Coracias affinis.

" assamiensis.

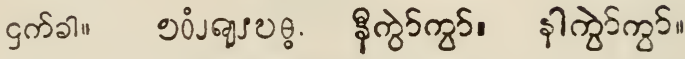

\section{BROAD-BILLED ROLLER.}

Another bird resembling a roller, but with a shorter and broader bill, and longer wings, tenants Arracan groves.

Eurystomus orientalis.

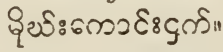

\section{BLUE-BACKED KINGFISHER.}

A small kingfisher with a blue back that I sent $\mathrm{Mr}$ Blyth, was
Alcedo bengalensis.

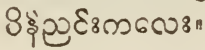
9อ̊งฺุ.

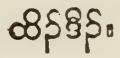

\section{LARGE KINGFISHER.}

A large blue-backed kingfisher is often seen on the banks of our rivers, whose skins are exported to China for their elegant feathers.

Alsedo sinensis.

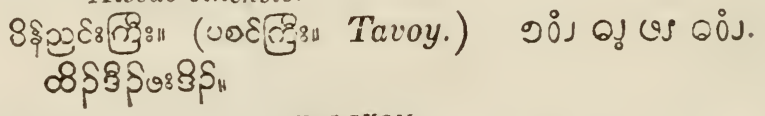
HALCYON.

The halcyon said to be another of the kingfishers on this Coast, common to India and Ceylon.
Halcyon gurial.
$8 \S 飞 \varepsilon_{80}$
פல்ง

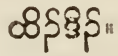

OTHER KINGFISHERS.

The Karens have distinctive names for five other species of kingfishers; and Capt. Phayre found three more in Arracan.
Halcyon Ameuroptcrus,
capensis,
(brown-winged.)

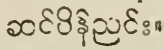
(blue-xinged.)
Ceyx purpurca,
(small.)

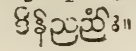


TROGONS.

Some of the trogons are most magnificent birds. The Trogon resplendens is said to have plumes three feet in length, intensely brilliant, of metallic golden green, which were used by the ancient Mexicans as ornaments to their head-dresses. A green-headed trogon is found in these Provinces, and a red-headed species in Arracan.
ITarpactes oreskios, erythrocephalus
(head green.)

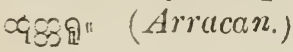
( "red.)

NIGHTJAR.

A nightjar, or goat-sucker, is one of our most common inocturnal visitors, and its loud sounding note may be often heard serenading the sleepless traveller in the stillness of midnight. Its monotone is so much like coke, the Karen word for chop, that whenever noticed by the Karens they say, "the nightjar is chopping down his trees." The American whip-poor-will is a bird of the same genus. Besides the common Tenasserim species, a second inhabits Arracan.

Cap,rimulgus macrurus

$$
\text { . monticolus }
$$

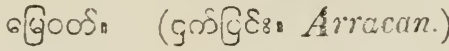

(Arracan.)

50105

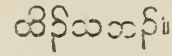

\section{LYNCORNIS,}

Mr. Blyth mentions another bird in the Provinces of the nightjar tribe, which he calls a very beautiful bird.

Lyncornis cerviniceps, Gould

SWALLOW.

A swallow resembling the common English species a. bounds over all parts of the Coast.

Iirundo.

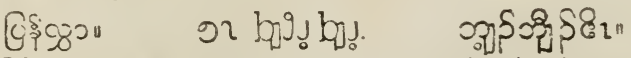

Capt. Phayre met with two other species in Arracan.

Hirundo rustica.

३थर:6zgर्.

Iirundo daurica.

Cิ\$8\%? 


\section{SHIXYTAILED SWIFT.}

The spiny-tailed swift, a bird resembling the swallow, terants the groves of Sandown.

Acconthylis caudacuta.

Hirundo “

Latham.

\section{EUILLE-NEST SWHALLW.}

The swallows, or swiftlets which build the edible nests, are so numerons in the limestone cares on the islets and islarcis on the Tayoy coast, that the Gevernment revenue from the bird-nest farm in 1847 was nearly eleven thousand rupees; but in $\mathbf{1} 49$, it was more than four thousand rupees less. At Mlergui they are not so numerous.

'The ateis are of several qualities, the best being those which are taken before the bird lays its eggs, and which sell in China for about forty-live rupees the pound.

In relation to the identification of the species $\mathbf{M r}$. Blyth says. "As regards the llirundo esculcnta of Limnaus, there If no reason to suppose that this as described, with yellow urides and white-tipped tail, has any prototype in nature: the latter would be an anomaly thronghout the cypselida, sut may refor perhaps to the white tail-markings of some real hirundo, erronecusly supposed to be the constructer of the edible nests. Dr. Horsfield gives the species term- d lant by the Jaranese as Cirundo esculenta, Osbeck stating that the specimens which he examined in Java, and those which he took to England, differ from Latham's description in being uniformly of a blackish colour, without a white extremity to the rectrices. Another species, the linchi of the lavanese, he gives as $\boldsymbol{H}$. fuciphaga, Thunberg stating that "its nest is constructed of mosses and lichens, connected with the same gelatioous subtance which composes the edible nest of the preceding -pecies. In the Journal of the Indian Archipelago, the same two species are distinguished by the names lackt and lintye, and the nest of the latter is described io be without the least value. And it is added: "The residence of these swallows, or swittlets, termed lintye in the cares, contributes greatly to the injury of the holes, for which reason they are destroyed as much as possible ne each gathering. 'The nests which they make are cont 
etructed of grass-stalks. They are, however, of the same form, and are as artfully made as the others.'

"Heer Hooyman likewise states, that besides the lawet, other species resort to the same caverns, which are named momomo, bocrong 4 itam, bocrong $-z o e k v e$, and lintje. 'Ihese,' he adds, ' are very similar to each other, excepting the second, which has the head larger; and the feathe rs of all are entirely black. The nests which they construct are black and friable, composed of a light down.' (Agglutinated?) 'An opinion prevails that the presence of these birds is injurious to the caverns, on which account they are driven away as much as possible.' A nother writer in the same volume of the Batariaasch Genootschap, mentions the momos or boerongitam (thus bringing together M. Hooyman's first two species,) as a large kind with plumed tarsi, indicating thus a true cypselus, which is probably the constructer of the nests assigned by Dr IIorsfield and others to the linchi. Assuredly however, the C. fuciphaga, ('Thunberg,) linchi or lintye of the Javanese, identical upon comparison with $J$ avanese specimens, would appear to be the sole producer of the numerous nests gathered on the rocky coasts of the Bay of Bengal : and the often quoted notice by Sir G. Staunton, in his account of the Earl of Macartney's Embassy to China, must refer either to $C$. fuciphaga, or to an entirely new species, which is hardly to be supposed in the locality. For he remarks: -Ihe birds which build these nests are small grey swallows, with bellics of a dirty white. The white belly is char. acteristic of $C$. fucinhaga; and this particular species occurs abundantly on parts of the coast of the Malayan Peninsula, in the Nicobar Islands, and the Mergui Archipelago, and so high as on certain rocky islets off the southern portion of the coast of Arracan, where the nests are annual ly gathered and exported to China. From all this range of coast we have seen no other species than fuciphaga, nor does it appear that any other has been observed; and we have examined a multitude both of the adults and of young takicn from the nests, collected in the Nicobars and preserved in spirit, all of which were of the same species. Still, what appears to be $C$. nidifica inhabits the moun 
tains far in the interior of India, though hitherto unobserved upon the coasts; and it is worthy of notice that $\boldsymbol{C}$. fuciphaya loes not appear to have been hitherto remarked inland in this country."

It may be here added that $C$. fuciphaga is constantly seen inland in these Provinces. The $\mathrm{K}$ arens in the valley of the Tenasserim in the latitude of Tavoy, are well acquainted with the bird, and they say it crosses the mounlains to and from the interior every year. That it is the same species there can be no doubt, for the Karen name of the bird is "the white swallow," from its white belly.

Collocalia fuciphaga.

Iirundo fuciphaga, \&०83.

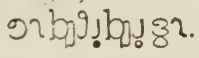

Thun.

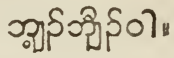

\section{GALLINACEOUS BIRDS.}

The Rasures, of which the domestic fowl is the type, embrace in these Provinces peacocks, peacock-pheasants, pheasants, wild fowls, partridges, three-toed quails, green pigeons, rock pigenns, wood pigeons, and turtle doves.

GREEN-NECKED FEACUCK.

The handsomest peacncks perhaps in the world inhabit nur forests in great numbers. They do not usually approach the towns, though $I$ have often seen them in the neighborhood of Burman villages. The Burmese hare a saying, that "wherever there are peacocks, there are tigers."

\section{Pavo muticus.

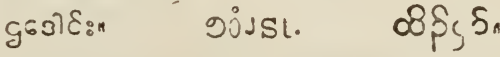

PEACOCK-PHEASANT.

The peacock-pheasant of Arracan is the 'Thibet peacock-pheasant, but the natives describe a crested peacock-pheasant as inhabiting this Coast, whose brilliant ocellated plumage equals in its play of colours the celebrated species of the Moluccas.
Polyplectron chinguis,
$P$ avo thibetanus,
Polyplectron emphanum,
6วิह89
90ง SL ชூ.
(Thibetian.)
(crested.)
\&) 
TENASSERIM PHEASANT.

A pheasant often seen in the neighborhood of villages, is abundant throughout all the Provinces, and in Burmah. Euplocomus lineatus.

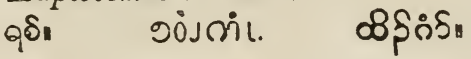

ARIRACAN PHEASANT.

The Arracan pheasant, Mr. Blyth says, is an intermediate race between the $A$ ssam and Tenasserim pheasants Euplocomus Horsfieldi. (Assam.)

\section{SILVER PHEASANT.}

The Chinese, or silver pheasant, I have seen in confinement, and the southern provinces are said to be its habitat, but I have never met with it in our forests. Capt. Phayre found it in Arracan. The chaste hue of this bird contrasts delightfully with the magnificent colouring of the other species.

\section{Phasianus fasciatus.}

\section{ARGUS PHEASANT.}

The Karens have shown me the quill-feathers of a bird that is found in Mergui, which I judge to belong to the argus pheasant.

Argus giganteus. ?

\section{TURKEY.}

The turkey has been introduced, but not extensivly.

Meleagris gallopavo.

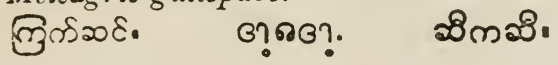

\section{JUNGLE FOWL.}

Wild fowls are so numerous, that the crowing of cocks at dawn of day in the deepest parts of uninhabited junglez, is quite as loud as in the centre of villages. All our domestic fowls are supposed to be derived from this species, which differs from the jungle fowl of Ceylon and Hindustan.

Gallus ferrugineus.

"bankivu:.

600 लुऽs.

3? $69 ?$. 


\section{WILD YELLOW IHEN.}

The southern Karens describe a gallinaceous bird which they call the wild yellow her, its colour being yellow and white. It is said to be the size of a hen, and that the male has two spurs on its legs, but I have never seen it.

$$
\text { ชา ๒ำ? } 20 \text { b? }
$$

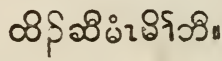

PARTRIDGES.

I have occasionally seen a partridge resembling the English partridge, without a spur, but it is a rare bird. There are two species in Arracan, but whether the same or not I am unable to say, as I have their names, but not their descriptions.

$$
\text { Pardix Phayrci. }
$$

จา॥

\section{THREE-TOED QUAIL.}

'The three-toed quail is a common bird on the sea-coast. Turnix atrogularis.

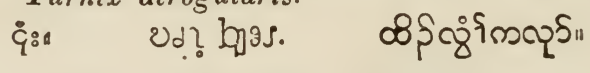

RED, AND PAINTED RARTRIDGE.

On the Irrawaddy, between Ava and Rangoon, Dr. Griffith met with" red and painted partridges and quails," but he does not give the systematic names.

Perdix chukar?

\section{ROLLULES.}

Mr. Blyth mentions a bird related to the partridge in these Provinces, which he calls.

$$
\text { Rollulus (?) ocellatus. }
$$

The corresponding race in Arracan he says is Arboricola atroguluris, Blyth.

YELLOW-BREASTED GREEN PIGEON.

This is the most common green pigeon in the Provinces. The male is " distinguished by having a large 
buff-orange patch on the breast, and above this a lilack band."

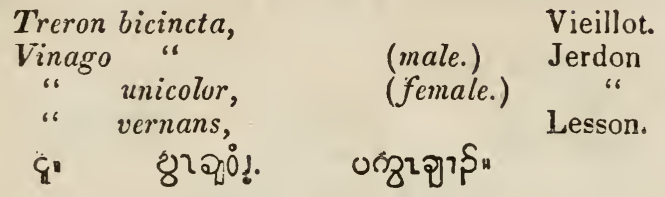

NEPAUI, GREEN PIGEON.

The Burmese and Karens have no name to distinguish this species from the preceding, but call both by the same name.
Treron nipalensis,
Toria
Hodgson.

XELLOWISH-HEADED GREEN PIGEON.

The natives see no difference between this species and the two preceding. "It is distinguished by having the anterior half of the head, and the medial portion of the tail, of the same yellowish green as the breast."

Treron viridifrons.

\section{MALABAR GREEN PIGEON.}

This bird has not been found in these Provinces, but it has been observed in Arracan, where the Arracanese cal! it $g n u$, as the Burmese do the other species.

Treron Malabarica

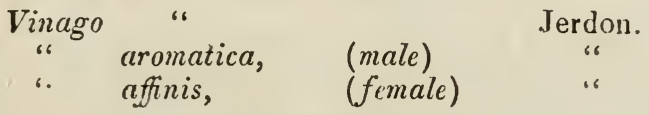

GAMPSORHYNCHUS.

Nir. Blyth describes a curious bird related to the green pigeons, and nearly allied to Swainson's genus sphenurus, which he received from Arracan.

Gampsorhynchus rufulus, Blyth.

PRUIT-PIGEON.

A large wild fruit-pigeon is often seen, and a second species has been found, in Arracan.

Carpophaga sylvatica,

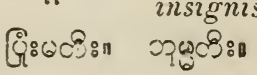


GROUND-PIGEON.

A handsome, dark-green ground-pigeon, is not uncoms mon.

Chalcophaps indica,
Columba
"
Linn.

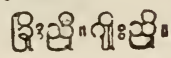
90ำ่ำ.
ณิรูก์โด

INDIAN ROCK-PIOEON:

This is the bird from which the domestic pigeons of India are derived, and which we have tame, if not wild. The principal difference, Mr. Blyth says, between the pigeon of India and Europe is, that the former " has a white rump and the latter a deep ash-coloured rump. There appears to be no other distinction between them; unless it be that the play of colours on the neck is finer in the Indian bird."

$$
\begin{aligned}
& \text { Columba intermedia. }
\end{aligned}
$$

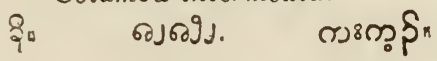$$
\text { nsim. }
$$

POMPADOUR WOOD-PIGROA.

"This is a wild pigeon whose "general colour is deep vinaceous ruddy," that Mr. Blyth had from the island of Ramree.

\section{Columba punicea.}

TURTLE DOVE.

The plaintive coo of this speckled turtle dove is heard alike in the neighborhood of our large towns, and in the depths of our thickest forests. It is often seen in cages, and is the turtle dove of the Bible.

\section{Turtur suratensis.}

Columba turtur,
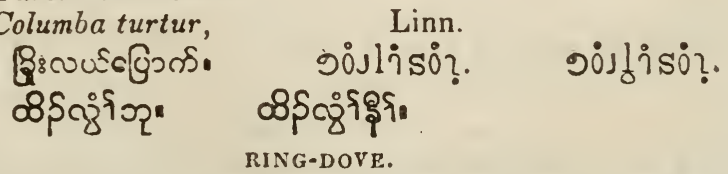

A turtle dove of a brick colour, with a half collar on the neck, sometimes called the ring-dove, is not uncommon. Turtur humilis.
Brose्धिon
90ำำ.

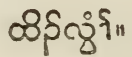


FOX-COLOURED TURTLE DOVE. often.

This is a brownish dove, seen occasionally, but not Turtur meena.

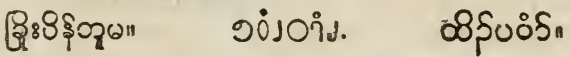

NICOBAR PIGEON.

The Nicobar pigeon with its elegant neck-frill, is sometimes seen in confinement, and the Burmese call it by the same name that they do the partridge, and roller. I have never met with it in the jungles, although some of the natives tell me it is found there.

Calænas nicobarica, Blyth.

Goura "

Geophilus nicobarensis. วิา

\section{WADING BIRDS.}

The Grallatores, or waders, are numerous. In these Provinces and Arracan, there are herons, bitterns, demiegrets, adjutants, cranes, ibises, open-beaks, rails or coots, water-hens, snipes, curlews, sand-pipers, oyster-catchers, snippets, turnstones, and plovers.

WHITE PADDY'BIRD.

Near the sea-coast, the bordering trees are often splendidly illumined with a beautiful heron, whose snowy plumage amid the deep emerald foliage, looks in the distance like magnificent white blossoms : it is called in this country the white paddy-bird.

Ardea alba.

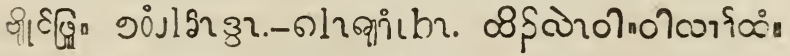
GREY HERON.

A species of grey heron is common at Taroy, in the interior as well as on the sea shore. The Karen name this bird bears at Tavoy, is at Maulmain appropriated to a species of rail or coot.

Ardea.

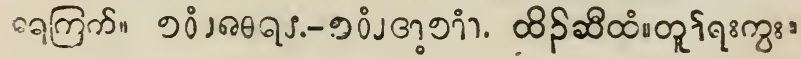




\section{NIGITT-HERON.}

In the dark silent night the royager is often startled by the dolorous scream of the night-heron along the shores, whose loud roar so much resembles the bellowing of a cow, that the Burmese call it the "cow-bird," which reminds us of the "bull-of-the-bog," one of the names of the bittern.
Nyctiardea,
Swain.

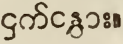

OTHER HERONS.

There are other herons on the Coast which I have not identified. Capt. Phayre found the following in Arracan. Ardea malaccensis.

वी ह86зวэरा"

Ardea purpurca.

बैंधी हः:

Ardea schistacea,

"fusca.

" ardesiaca,

" cincrea

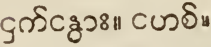

Nycticorax* griscus

(large, slate colour.)

(brown.)

(small, slate colour.)

(common British, brown.)

(niglit-heron.)

DEMI-EGRET.

A demi-egret is met with in Arracan, but I have never seen it in these Provinces. "Colour," says Mr. Blyth, " uniform dark slaty throughout; some specimens having a white line on the chin and throat. Adults have narrow lengthened plumes on the back and breast, similar to those of Ardea cinerea : the occipital plumes also are somewhat lengthened, as in herons generally; but I have seen no defined occipital crest, and doubt its ever possessing one. Beak mingled dusky, and dull yellowish, and the legs ap. pear to have been olive-green."

Demigretta concolor. 
TIGER BITTERN.

The Asiatic Society's Museum in Calcutta contains specimens of a curious tiger-bittern received from Arracan. Tigrisoma melalophos.

ADJUTANT.

Among the problems given Dr. Helfer to solve when he visited our shores, was, to ascertain if the breeding of adjutants takes place here, "as well as its manner." He replied on returning to Calcutta: "The Ciconia cirgala, or the common Calcutta adjutant, is never seen on that Coast." Here he was mistaken. It is very common in Province Amherst; and it builds its nest, the Karens inform me, in the inaccessible summits of the nural limestone rocks, and occasionally near the tops of large woodoil trees.

The under tail-coverts are delicate and floating, forming plumes of the most exquisite texture, which, in Maulmain command a high price. These plumes are known in England by the term marabou, a name taken from the African species. 'The natives tell me there are two species of adjutants, one of which produces finer plumes than the other; but I have seen only one, and doubt the existence of two species.

Ciconia argala, Leptoptilas argala.

Vigors.

Argala gigantea.

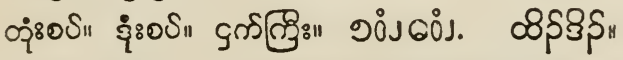

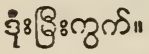

(with handsomest plumes.)

BLACK AND WHITE WADING-BIRD.

A bird described as a crane, or tantalus, with a white breast, and black bill, head, and back, is found in Amherst province, but I have never seen it. A part of the plumes offered for sale are said to be the under tail-coverts of this bird, but inferior to those furnished by the adjutant.

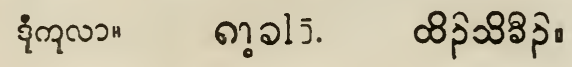


CRANE.

A large slate-coloured crane is often seen stalking about the paddy fields, and near the sea-shore. It is sometimes called the adjutart without a pouch.

Grus antigone.

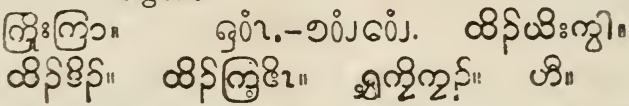

RED-RUMP.

A bird which I have not scen is represented to me, by the natives, as of the heron tribe, but is said to have a red rump. The Burmese call it by the name given to the broad-bill in Arracan.

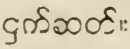
รอำวา วรุ.
ه

IBIS.

Capt. Phayre met with a white ibis in Arracan, nearly related to the sacred ibis venerated by the Egyptians.

Illis Macei.

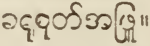

OPEN-BEAK.

Another bird of the ilis tribe inhabits Arracan, whose lower mandible is curved, and touches the upper at the base and top only.

Anastomus coromandclianus.

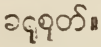

RAIL OR COOT.

In Province Amherst, I have noticed a species of rail or coot.

Rallus, vel Fulica.

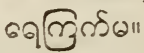

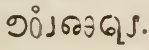

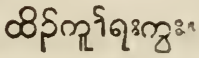

WATER-HEN.

A species of water-hen inhabits Arracan.

Gallinula javanica.

" plicnicura.

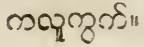


SNIPE.

The snipe is a very common bird in the Provinces, but commands a high price in bazar.

Scolopax heteruna,

(Arracan.)

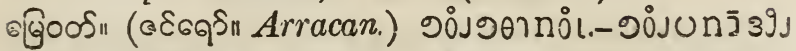

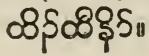

कर्ड

CURLEW.

The curlew is quite abundant on the sea-shore.

Numenius arquata,

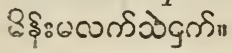

(Arracan.)

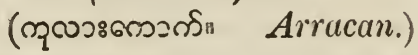

TURNSTONE.

I think I have seen the common turnstone, on the seaboard.

Strepsilas interpres.

OYSTER-CATCHER.

Mr. Blyth has had specimens of the common European oyster-catcher from Arracan, and I believe it inhabits these Provinces. He appears to regard it as identical or nearly so with the Australian species, so it is a very widely distributed bird.

Himantopus ostralegus.

" longirostris (Australia.)

SAND-PIPER, AND SNIPPET.

Sand-pipers and snippets are common in Arracan, and if I am not mistaken on this Coast also.
Tringus,
Totanus,
बहธตุर्:
(Sand-piper.)
(Snippet.)

SPUR-WINGED PLOVER.

A species of plover with a spur on the wing is a common bird.

Plivianus spinosus.

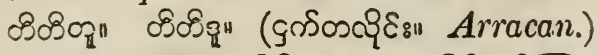

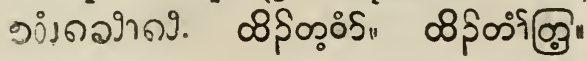

$A^{*} *$ : 
COMMON PLOVER.

A species of plover without a spur is also seen.

Pluvianus goensis,

(Arracan.)

\section{SWIMMING BIRDS.}

The Natatores, or swimming birds, consist in these Provinces of wild ducks, teal, pelicans, snake-birds, cormorants, sea-swallows, gulls, and scissors-bills.

\section{WILD DUCKS.}

At least one species of wild duck is common on this Coast, and two are known in Arracan. One afternoon, having made a sudden egress, with my Karen guide, from a tunnel unier Dongyan mountain, we raised an immense number. Hundreds and hundreds of ducks, teal, and other water-fowl burst from the rocks and fens, and wheeled over our heads, forming thick clouds forty or fifty feet above us, and all uttering one continued clang of wild sea music.
Dendrocygna major,
Plectropterus melanotus, 605280 S $\partial_{11}$
รั่งรา 6ิ?.
(Arracan.)
66
ห⿻ง

TEAL.

A species of teal is seen in great numbers on the plains, where there are lakes and ponds of water.

Dendrocygna arcuata, ofoç

$$
\text { รวำวรวำ. }
$$

(Arracan.)

\section{BLACK-BANDED TEAL.}

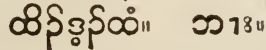

The Karens describe a small teal with a black band around its neck, which I have not seen, nor do I find it described.

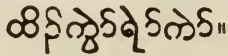

GOoSE.

The goose has been introduced into the Provinces from other parts of India. All the domestic geese in India, Mr. Blyth says, are the mixed progeny of Anser cinereus, and

"cygnoides.

cईะ1 
PELICAN.

This princely water-bird is no where abundant in these Provinces, yet it is seen netting fish with its capacious pouch in our solitary lowland streams and ponds. It is a fine swimmer, and the natives say it wheels high orer the waters, then makes a sudden graceful sweep upon the shoals of fish beneath, which it skims up in great abundance.

$$
\begin{aligned}
& \text { Pelecanus rufescens? }
\end{aligned}
$$

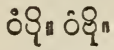

SNAKE-BIRD.

On some of our inland streams the darter is common. This bird resembles the cormorant, but has a much longer neck, which it lifts above the water when swimming, while its body is immersed, with a snake-like motion.

Plotus Vaillantii. ๙रतกิ"

$$
\text { פว่งlรา. }
$$

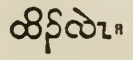

CORMORANT.

The cormorant, that ominous bird so dreaded by the Draids, has one representative on this Coast, which may be often seen fishing on the banks of fresh-water streams and ponds. Wordsworth, alluding to the sea-mew scream. ing around the arch Druid's brow, adds :

"And toward the mystic ring

Where augurs stood, the future questioning,

Slowly the cormorant aims her heavy fight,

Portending ruin to each baleful rite."

This bird is a noble fisher, and trained to that business in Holland and China. In Arracan it has the same name as the darter, but I have never heard that name applied to it in these Provinces.

\section{Phalacrocorax Javanicus?}

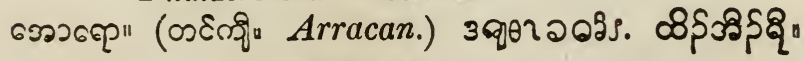
SEA-SW ALLOW.

A species of tern, or sea-swallow, as these birds are called in England, is often seen on the coast.

Sterna poliocerca,

Thalascus cristatus, ?

Go 808 :"
Gould.

Stevens. 


\section{OTHER SEA SIVALLOWS.}

Four other species of tern which are found in the Bay of Bengal, probably visit our coast.

\section{Thalasseus, Bengalensis.}

Melanostcrna anasthatus,

syn. Stcrna panaya,

$$
\begin{aligned}
& \text { " " infuscata, } \\
& \text { " " antarctica, } \\
& \text { " grisea, ? }
\end{aligned}
$$

syn. Hydrochilcdon,

" " marginata, Anous tenuirostris,

Scopoli.

Lath.

Licht.

Lesson.

Horsfield.

"s

Blyth.

Temm.

GULL.

Gulls are common on the sea-shore, where they are called by the natives "sea-parrokeets."

\section{Larus fuscus?}

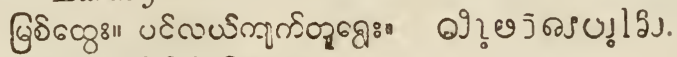

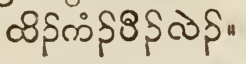

\section{SCISSORS-BILL.}

At Tavoy the sheer-water, or scissors-bill, is frequently seen cleaving the water with its curious bill, the upper mandible of which is much shorter than the lower. It has never been noticed among the collections of birds sent to Calcutta, either from these Provinces or Arracan. A specimen that I examined differed in no important respect from the European species.

\section{Rhynchops nigra. \\ u हcouscutgiर⿰丿

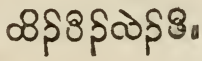

\section{TROPIC-BIRD.}

A single species of tropic-bird, or boatswain-bird, with its two long tail feathers, is known to inhabit the Bay of Bengal; and it is rather remarkable that while it differs from the species found near the Mauritius on the west, $P h$. candicus; and from the species found towards Australia on the east, $\boldsymbol{P h}$. phanicurus; it is identical with the common tropic-bird in the Atlantic Ocean.

Phaton athercus. 


\section{ICATHYOLOG $\mathrm{X}$.}

"Almost every reptile and fish of the Tenasserim coast must necessarily be new," remarked a gentleman of no ordinary scientific attainments. And it is a rery common error to suppose that, because the productions of at country are unknown, they are therefore new to science. No one appears to have examined our fish, but a collecof twenty-seven species that I sent Mr. Blyth, contained only one new species, though the principal part of them were fresh-water fish; and from the little attention I have been able to bestow upon them, I judge that by far the larger proportion of our fishes are cummon to other coasts bordering the Bay of Bengal.

\section{LARGE SCALED-FISH.}

The Macroleptes, or large-scaled fish of the order with spinous rays in the dorsal fin, embrace on this Coast, perch, cockup, band-fish, umber, Indian whiting, mullet, inango-fish, king-fish, climbing perch, and snake-heads.

\section{LARGE PERCH.}

A perch which sometimes grows two feet long is often seen in Maulmain bazar, and is esteemed a valuable fish by Europeans. The formula of the fin rays is,
D. 7,1-11: P.
Perca.

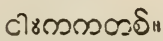
ขรวรวดิา.

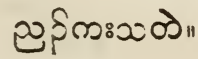

SMALL PERCH.

A small species of perch is common in the interior of the Provinces.
D. 7, 1-14: P. 10:
Perca,
V. 1-5: A. 3-15: C. 18.

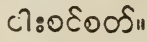
Linn.
องวา่ง.

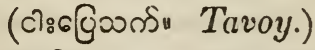
已र

- That is D., the dorzal has in the first fin 7 rays all spinous; in the secon 1 fin 1 spinous, and 11 that are soft. P., the pectoral fin, has 15 soft rays. $V$. , the ventral fin has 1 spinous ray, and 5 that are soft A., the anal fin has 3 Epinuus and 8 soft rays $\quad$., the caudal till has 17 rays. 


\section{COCKUP.}

A fish which Europeans in India call cockup, is very common on the coast, and often ascends the large rivers a long distance. Crawfurd found it a hundred and twenty miles from the sea, in the Irrawaddy, and characterizes it as "cne of the best Indian fishes." It resembles the basse, or wrasse, and I know it from examination to be of the genus lates, and I have good reason to believe it is $\boldsymbol{L}$. nobilis, though I am unable to speak with certainty, for the want of books which describe that species.*

Lates nobilis?

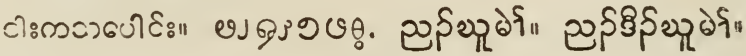

SILAGO.

A salt-water fish less than a foot in length, with the first ray of the two dorsal fins very long, is seen occasionally in bazar. It belongs to Cuvier's genus silago, and Mr. Blyth, to whom I sent a specimen, said it was

silago acuta.

cी:0688"

BAND-FISH.

At the fishing villages on the sea-coast I have noticed a species of chætodon, or band-fish.

Chcetodon.
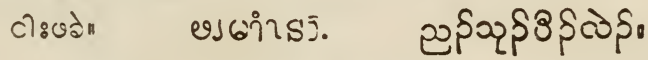

\section{ELEPHANT-EAR FISH.}

A fish of the chrtodon tribe, which the natives call "elephant's ear," from its shape, is found in great abundance on the Tavoy coast. It resembles

Pomacentrus marginatus.

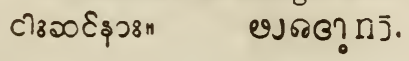

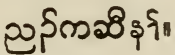

- Crawfurd gires Cais racti as the systematic name of cockup, but that is a spe. cies of India whiting, and I have the authority of Dr. M 'Clelland for appropriating the name to $L$. nohilis. 
UMBER.

A species of umber, a fish resembling a perch, sometimes called sea-perch, was among the described species that I sent Mr. Blyth.

Sciana.

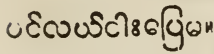

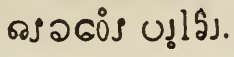

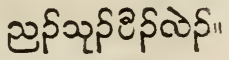

\section{INDIAN WHITING.}

There are two or three species of fish common in Calcutta that are called whiting, from their resemblance, both in form and flavour, to the European fish of that name. One species is frequently seen in the Maulmain bazars, and besides being a good fish for the table, its air-bladder makes excellent isinglass. I think I have observed more species than one sold under the same native name, but the specimen I sent Mr. Blyth he said was

Corvinus coitor.

cใఃบุo

BOLA.

This is another species of Indian whiting that also furnishes isinglass, and which Mr. O'Riley sent up to Calcutta from Amlierst. Dr. M'Clelland wrote : "It belongs to the genus corvinus, closely allied to $C$. niger, but of monstrous dimensions compared with the European species."
Bolo chaptis,
Corvinus "
Buch.
sosencos:a
M'Clell.
O'Riley.

LARGE MULLET.

A species of mullet is very common, and is often seen on the tables of Europeans, by whom it is highly esteem. ed. Mr. Blyth, to whom I sent a specimen for the determination of the species, wrote that it was abundant in Calcutta, but "is of a species I could never determine from descriptions."

$$
\begin{aligned}
& \text { Mugil. } \\
& \text { ç8mssoga }
\end{aligned}
$$




\section{LARGE-EYED MULLET.}

We have another mullet, equally valuable for the table with the last, and equally common in Calcutta, but distinguished among other things by its small head, smaller scales, and goggle eyes which appear to be starting out of its head.
Mugil cepsalotus,
cใรo\&s"
ejoseq
Vallenciennes.

SMALL MULLET.

A small mullet is often found in great numbers in the river near Maulmain, which many of the Burmese regard as the young of the preceding, but it is a distinct species, of which Mr. Blyth wrote that he had never seen it be. fore, but had "made it out to be"

Mugil subviridis,
clsç"

MANGO FISH.

This is a splendid fish and a favorite with many. It is nearly related to the mullets, and remarkable for the long filaments to the pectoral fins.

Polynєmus paradiscus.
Risua,
Buch.
cใญ่รวรн

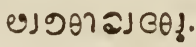

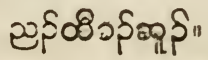

KING-FISII.

A few years ago the attention of the Commissioners of these Provinces and Arracan was drawn to the fish that produce isinglass; and the result was, the discovery on our shores of the species of Indian whiting noticed above, and Polynemus sele, a fish that is found from Calcutta to Otaheite. The polynemus produces isinglass of the best quality, and Mr. O'Riley estimated that two thousand pounds might be obtained annually off Amherst alone. None of our merchants have yet entered into the isinglass speculation, but the sounds are a constant article of traffic among the Chinese.

Mr. Blundell said the largest sounds were exported from Rangnon, and that they sell here at about half a rupee a 
pound ; and Major Bogle wrote, that about ten thousand of the fish, large and small, were taken annually in Arracan, and that the sounds sold there for about a third of a rupee per pound to the Chinese, who exported them to Penang, where they are said to bring more than a rupee a pound. The specimens that have been prepared in India for the European market, are "complained of," says Dr. M'Clelland, " as being too thick, if intended to come into competition with the superior varieties of Russian isinglass. The first quantities sent from India hrought only $1 s .7 d$., others have been sold for $3 s$, , and a few samples have been valued at $4 s$. per pound."

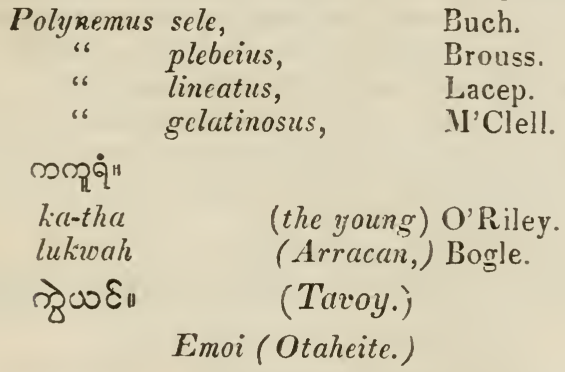

CLIMBING PERCH.

The climbing perch is a small fish, abounding in our waters, which has the power of climbing up out of the water on the roots of trees, and which will make its way on land, the Karens say, a quarter of a mile. It corresponds precisely to Gmelin's description of Perca scandens in his edition of Linnæus, excepting in some of the finrays; more especially in the soft rays of the dorsal and anal. It was placed by Cuvier in his genus anabas, and to this Mr. Blyth referred a specimen I sent him; but the fin-rays differ sufficiently to constitute it a distinct species.

D. 17-25: P. 12: V. 1-6: A. 10-18: C. 1\%.P. scandens, Gmelin.

D. 17-9: P. 13: V. 1-5: A. 9-12: C. 17. The T'nasserim. fish. 


\section{AMPHIBIOUS SNAKE-HEAD.}

Two or three species of ophiocephalus are very common. They are fresh-water fish, appropriately named, for the head is very much like a snake's head, and they are remarkable for the power of making their way from one pool to another on land. One species it is said, usually lives in hollow logs and holes, never in streams, and often a long time in the jungle without water. It appears to be either the same species, or a nearly related one to the burachang of Boutan, which the natives believe falls from heaven, from the circumstance of its being found after rain far from the water. Some of the Karens regard these with a superstitious awe, and abstain from eating them. 'They have a legend that they were formerly men, changed into fish for their sins; and the Pwo Karens at 'Tavoy say: "If people eat them, they will be transformed to lions." The fame of this fish had reached Greece more than two thousand years ago, for it is mentioned as a remarkable Indian fish by 'Theophrastus.

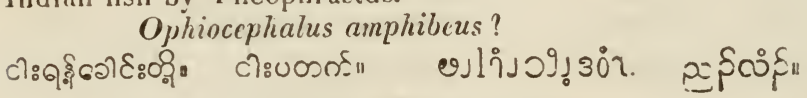

\section{SPOTTED SNAKE-HEAD.}

A species of ophiocephalus common at Maulmain, is remarkable for three black spots on the body just below the lateral line, at equal distances between the termina. tion of the pectoral fins and the base of the caudal; and a bright red circle on the base of the upper lobe of the caudal fin, occupying nearly the whole breadth, with a deep black centre. 'Two small black dots are seen on the same lobe a little above the circle, and the dorsal and anal fins are spotted with white at the base, while these with the caudal are nearly black on the margin. In some specimens a reddish stripe runs from the eye just above the lateral line to the red spot on the tail. The back is dark, and the belly of a light or whitish colour. $\boldsymbol{A}$ full grown one is said to be a yard long. The fin-rays are,

D : 50. P. $16:$ V. $5:$ A. $36:$ C. 12. (long rays.)

Ophioccphalus.

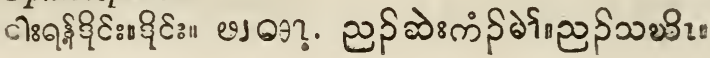




\section{BANDED SNAKE-HEAD.}

A species of ophiocephalus with a singularly variegated marking is occasionally brought to the bazars. The upper parts are dark olive green, and above the lateral line the body is crossed with from fifteen to eighteen dark bands. The lower parts are tinged with rose on the sides, and banded with dark lines so as to meet the upper bands on the lateral line, and form an obtuse angle. It rarely grows a foot long.

I sent Mr. Blyth a specimen of either this species or the preceding, and he wrote: "This ophiocephalus is, I believe, not named, but I have before had it from Goalpara." The fin rays are,
D. $33:$ P. $15:$ V. $5:$ A. 25: C. 11.

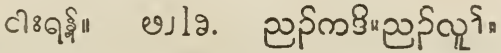

SMALL SNAKE-HEAD.

A smaller species of ophiocephalus, the natives call

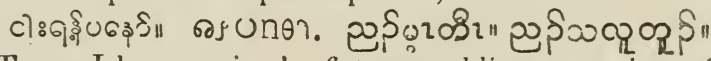

At $\mathrm{T}$ avoy $\mathrm{I}$ have noticed a fish resembling a species of ophiocephalus, but of which I have no notes.

$$
\begin{aligned}
& \text { cी800600? } \\
& \text { อง วง رِร }
\end{aligned}
$$

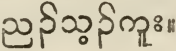

\section{SMALL-SCALED FISH,}

The Microleptes, or small scaled fish, including the other tribes with spinous rays in the dorsal fins, do not appear to be very numerous; but they are represented in our waters by Indian mackerel or tunny, ophidians, longsnouts, dories, pomphrets, ribon-fish, flat heads, gobies, amblyopus-suckers, and periophthalmi.

TUNNY.

A fish of the mackerel tribe, often called Indian mackerel, or Indian tunny, belonging to the genus thynnus, is not uncommon at Tavoy.

Thynnus.

OPHIDIAN.

This fish is often described as resembling a small eel, but ic has strong spines on the back, and before the anal fin. 


\section{Rhynchobdella ocillata. . cis68ु०:"1 \\ es $3 \theta$ ?. \\ อง}

BANDED OPHIDIAN.

Of another fish resembling the abore in form, but of more brilliant colours, Mr. Blyth wrote: "The mastacembalus with transverse stripes is a new species." A green and yellow ground on the back and sides is crossed by about twenty fire blue bands. There are 29 spines before the dorsal, and three before the anal, and there are three on the preoperculum.

Mastacembalus.

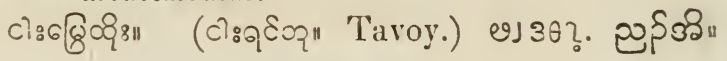

LARGE-SNOLT.

A fish of the same tribe as the two preceding species is

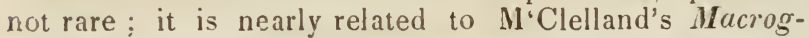
nathus undulatus from Chusan. Like that it has 37 spines on the back in front of the dorsal, and three before the anal. The pectoral fin is also round, and contains about 20 rays. It differs howerer in having a truncated caudal with about 20 rays, instead of a lanceolate one, and in the figuring on its sides.

Macrognathus.

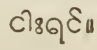
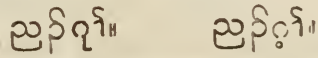

SMALL DOREE.

A small fish of the dorce tribe, common in our waters, Mr. Blyth said was,

Equula ruconius.

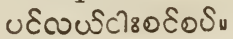

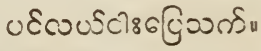

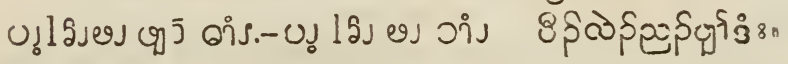

POMPHRET.

This fish is very abundant on the Taroy coast, and in a smooth sea may be seen deep in the water in great numbers, but they are very shy of the hook. They are considered one of the best fish for the table.

Stromateus?

Linn.

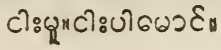




\section{RIBBON-FISH.}

A species of ribbon-fish is very common at ' $\mathrm{T}$ avoy, and is dried in large quantities.

Gymnetres.

$$
\text { c1803รईग?" }
$$

esbar be?.

FLATHEAD.

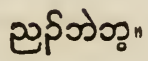
be

A species of flathead which I sent Mr. Blyth proved to

Platecephalus chaca. GOBY.

A small fish about six inches long, with two dorsal firs and a depressed head, the under jaw projecting, is found in the bazars.

Gobius giuris.

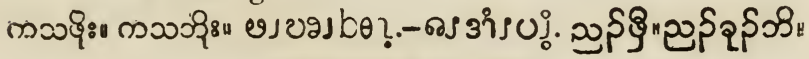
PO:NT-TAILED GOBY.

A small goby with a lanceolate tail, and teeth on the front of the jaws like a pike, is sometimes seen in bazar. The dorsal and anal fins are long, reaching nearly to the base of the caudal.

\section{Gobius?

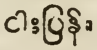 \\ एృ $\{03$ "}

AM BLYOPUS-SUCKER.

This is an ugly looking fish, with the form of a small eel, having the ventral fins united into a concave disk like a sucker. The lower parts are red, and the upper lead colour.
Amblyopus
Psilosoma,
Cuv.

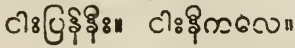
Swain.

\section{PERIOPHTHALMUS.}

At least two different species of this genus may be seen hopping about, in and out of the water, on every mudbank within the reach of tide-waters. Europeans often call them frog-fish.

Periophthalmus.

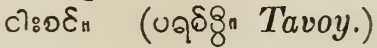

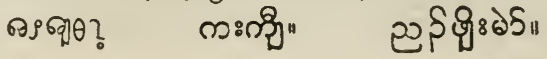




\section{CARP FAMILY.}

The carp tribe has more species in these Protinces than any other family with which $I$ am acquainted. It embraces representatives of carps, cirrins, labeo, barbels, breams, sustomus, perilamps, opsarions, bacailas, gudgeons, white-fish, and loaches.

\section{CARP.}

Buchannan says of the catla that it "differs from the common carp of Europe only in wanting ciri.." The carp of our waters has precisely the same number of fin rays as the catla, and four cirri also, like the European carp ; but $\mathrm{M}^{\prime}$ Clelland adds: "It also differs from that species in the want of spinous rays in the dorsal and anal, as well as in general form. It approaches however, much nearer the Prussian carp, $C$. gibelio, the general figure, character of the fins, and number of their rays, being the same in both, but they differ in the size of their scales and proportion of the head."

Our species, although it bears a strong resemblance to the European carp, does not correspond exactly to the description of any European, or Indian species to which I can refer. It belongs to the genus cirrinus as defined by $\mathrm{M}$ 'Clelland, which he says is "represented in America by the catastomi, and in Europe by Cyprinus proprius." The peculiar fleshy lips of this and the two or three species following, bear a rery strong resemblance to the lips of the catastomi of the Ohio river. Unlike the catla the head is short, forming about one fourth of the whole length from the snout to the base of the caudal fin, and its depth about two thirds of its length.

The back which is raised like the common carp, is of deep lead colour, gradually growing lighter towards the belly, which is white; but the centre of each scale all over the body is tinged with red, of greater or less intensity, which distinguishes it at a glance from the allied species. There are forty two scales on the lateral line, and fourteen from the ventral fin to the first ray of the dorsal.
D. 18 :
P. 18 :
V. 9 :
A. 8 :
C. 19 . 


\section{Cyprinus, Cirrinus, cीรร์จุ์}

Buch.

$M^{\prime}$ Clell.

e) ब.

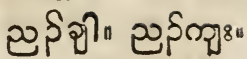

CALABASU CARP.

This is a dark coloured fish with deep blue reflections, and thick pendulous lips, like the American catastomus. It is a common fish in Bengal, and was placed by Cuvier, incorrectly however, among the barbels; by Buchannan among the carps, and by M'Clelland in his genus cirrinus.

Cirrinus calabasu,

Cyprinus

Rohita

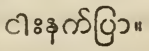

ejosugr.

M'Clell.

Buch.

Blyth.

NANDINA CARP.

Another of Buchannan's carps called nandina in Bengal, is sold in the bazars of Maulmain under the same native names as the preceding, although the dorsal fin is much longer. "The colour of the upper part of the body is dark green, with coppery reflections: below, it is white; the fins are dark and the eyes red." M'Clelland found it in the Bramaputra, but was not aware of its exis. tence on this Coast.

Cyprinus nandina,

Cirrinus
Buch.

M'Clell.

ROHITA LARP.

This species is rare in the Provinces, but large quantities are imported, dried and smoked, from Burmah Proper. Buchannan says: "It is a most valuable fish."

Cyprinus Rohita,

Cirrinus

cीรงిระ"
66

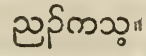

Buch.

M'Clell.

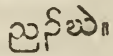

LABEO.

A small scaled fish of the carp tribe, with reddish iridescent scales, and no cirri, which grows a foot and a half long, is occasionally seen in the Maulmain bazar. It has fifty eight scales on the lateral line, and nineteen or 
twenty in a cross line from the ventral to the base of the dorsal fin. The fin formula is,

D. $16:$ P. $13:$ V. $9:$ A. $5:$ C. 20.

Cyprinus,

Labeo,

Buch.

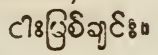

M'Clell.

\section{ङิરી"}

MORTON BARBEL.

This is one of the most beautiful fish in the Provinces, and when removed from its own element, its burnished scales of green and yellow glisten and play in the sunlight, like a panoply of brilliants.

Length of the head to that of the body as one to four, twenty three scales along the lateral line, and six in an oblique line from the base of the ventrals to the base of the spinous ray before the dorsal. The fin rays are,
D. 10
P. 12 :
V. 8 :
A. 7 :
C. 20.

It appears to be a new species, for it is not described in M'Clelland's monograph of the Indian cyprinidæ, but approaches nearest $\boldsymbol{B}$. hexagonolepus, from which it differs materially in the scales and fin rays, and in the general form and tints, as represented in M'Clelland's coloured figure of that species. Though common in the southern Provinces, I have never met with it at Maulmain.

The species has been dedicated to Dr. Morton, Civil Surgeon to the 'Tenasserim Provinces, a gentleman no less distinguished for his knowledge of the natural productions of this Coast, than for his urbanity, skill, and be. nevolence in his profession; and who is well acquainted with the haunts of this fish at the Sacred Lakes in the vicinity of Tavoy.

These lakes, or reservoirs, are two small currentless basins in Pagaya river, which sleep at the foot of pagodacrowned precipices from one to tivo hundred feet high. The fish are held sacred by the Buddhists to those antique pagod reliques, and come in shoals to the handfuls of rice thrown them by the passing traveller, as fearless of man, as of the barking deer that quaffs of their waters.
Barbus Mortonius,

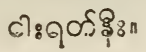
esconj.
20 $\left\{\operatorname{gn}^{5}\right.$
F. M. 
LONGIIEARDED BARBEL.

I have never seen the fish designated by the native names below, since I received M'Clelland's work on the cyprins, but the "peculiar appendages to the lower jaw," distinguishes it from all others, and there is little room for doubting the identity of the species. It is not a very abundant fish.
Barbus progencius,
Cyprinus tor,
M'Clell.
cใ:ดุoso.
อง 600 ำ.
Bucl.

TAVOY MOUNTAIN BARLEL.

This fish does not appear to have been described, and might be brought into the genus cyprinus, or carp, as described by some writers, but according to M'Clelland's arrangement it is a species of mountain barbel. It has two small cirri on the upper jaw, the dorsal fin is long with sixteen rays, and the scales are small; thirty three on the lateral line.

Orcinus.

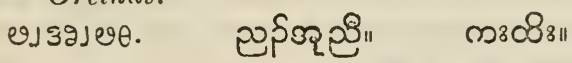

TENASSERIM BREAM.

I call this fish a bream, though it has a bony ray in the dorsal, because in every other generic respect it corresponds to the English bream, which it much resembles in form. The Karens call it "the peepul leaf," from its oral form. The formula of the fin rays is,

D. 9: P. 15: V. 9: A. 19: C. 19.

Abramis.
cी80ईะ०॥

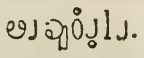

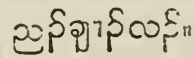

NARROW-MOUTHED CARP.

A class of small fish that were referred to the carps by Buchannan, M'Clelland has formed into a new genus, which he calls systomus, from their small mouths, and of which we have several species. One is distinguished for a yellow caudal fin, edged with black.

Systomus.

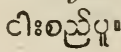

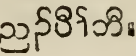




\section{BLACK-BANDED SYSTOMUS.}

Another species of systumus, with two small cirri to the upper jaw, and blackish bands on the sides, that grows as large as a barbel, is not uncommon at Tavoy. 'The ventral and anal fins are reddish, and there are tweniy five scales on the lateral line.

Systomus.
cisतुरह:
e) 8?.

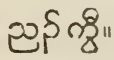

BLACK AND RED TAILED SYSTOMUS.

A handsome species of systomus, that I think is undescribed, has the extremities of the dorsal, ventral, anal, and caudal fins, of a bright scarlet colour; but the external rays of the caudal fin are deep black, contrasting boldly with the red rays. 'Two small barbules are attached to the upper jaw, inter-opercula black with a small black spot immediately above them, and sub-opercula tinged with red. The spinous ray of the dorsal fin is serrated, and there are thirty one scales on the lateral line. and thirteen on an oblique line from the base of the ventrals to the base of the dorsal.
D. $9:$ P. 11 :
S'ystemus.

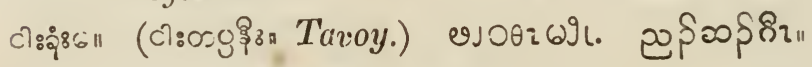
V. $9:$ A. $7:$ C. 19 .

\section{BLACIK SPOTTED SYSTOMUS.}

Another species of systornus is abundant, with the general form of the preceding, but wanting its colours, though the gill covers are yellowish, and the ventral fin slightly tinted with red. It has no barbules, and the dorsal spinal ray is not serrated. There is a black spot on the dorsal fin, and on some specimens a black band across the caudal fir. Twenty four scales are counted on the lateral line, and nine in an oblique direction across the body. In general appearance it strongly resembles $\mathbf{M}$ :Clelland's figure of $\boldsymbol{S}$. malacopterus, but corresponds nearest to the description of $S$. sophore.
D. 9 :
P. 15 :
V. 10 :
A. 7 :
C. 20 . 

Systomus sophore, ?
Cyprinus
M'Clell.
cาจุ" cาจุฒ
e) vij ชิ?
Buch.

\section{ROSE-FINNED SYSTRMUS.}

Another species of systomus, with red-tipped fins, and without barbules, is common.

Systomus.

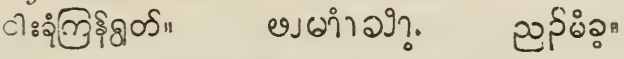

BLACK-TAILED SYSTONISS.

Another small fish, from four to sis inches long, with the caudal fin partly black, and hence called by the Burmese the black tailed fish, is, I think, a species of

Systomus.
c): (8).
e) $3 \theta$ ใด्थ?.

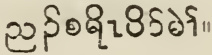

BLACK-BACKRD sYsTOMUS.

One species of the genus is characterized by a black back.

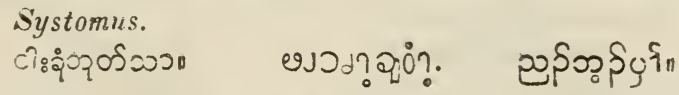

FERILAMP.

A small fish belonging to Cuvier's genus abramis, or bream, but which falls into M'Clelland's new genus perilampus, abounds here The mouth is placed on the upper part of the head, the back straight from the head to the tail, and it appears to be nearly related to $\boldsymbol{P}$. perseus, but they differ in the fin rays.

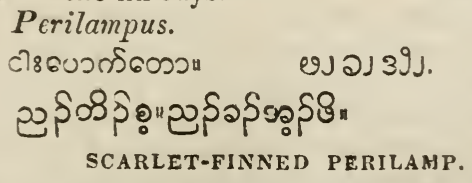

A distinct species with reddish fins, the mouth opening upwards, and the lateral line near the edge of the belly, is common at Tavoy.

Perilampus.

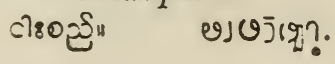


OPSARION.

Among our small fish of the carp tribe, is one with a greenish back.
D. 8: P. 12: V. $8:$ A. $19:$ C. 30.
Opsarius pholicephalus?

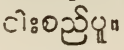

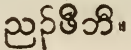

WHITE BELLIED OPSARION.

Another opsarion, with a silvery white abdomen, and golden green back, is nearly related to one of $\mathbf{M}$ 'Clelland's species.
D. 9: P. 12:
V. 7 :
A. $20:$ C. 19.
Opsarius albulus,
Cyprinus phulo,

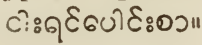
(2)
M'Clell.
Buch.

BACAILA.

A species of opsarius resembling the preceding, with the same native names, I sent to Mr.Blyth, who said it was Bucliannan's bacaila.
Opsirius bacriila,
Cyprinus
N'Clell.
Buch.

\section{LARGE GLDGEON.}

A species of gudgeon which grows from one to two feet long, is often seen in the ivaters of Amherst Province. It differs from all the species described by $\mathbf{M}$ 'Clelland, but appears to be the Tenasserim representative of the Bengal mrigala, or mirga. The head, eyes, and mouth, with the upper jaw projecting over the under, two minute cirri on the upper jaw, and head and back green, all correspond with the Bengal fish; but there is a material difference in other respects. Our fish has thirty eight scales on the lateral line and eleven in an oblique line from the base of the ventral to the dorsal. The fin rays are,
D. 14 , or 15 :
P. 16, or 17 :
V. 10
A. 7 : C. 20

Gobio.

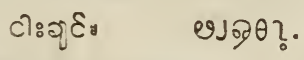

- Cuprinue mrigala,

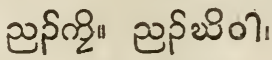

Buch. 


\section{RED-EXED GUDGEON.}

A species of the same size as the preceding with red eyes, the back lead colour with the scales on the sides red in the centre, is found occasionally in the Salwen. It appears to correspond nearest to Buchannan's Cyprinus pangusia, but differs in some respects, and the back is much more arched than that species in $M^{\prime}$ Clelland's figure. It is destitute of cirri, the lips are fleshy, and the intestines very long. There are forty one scales on the lateral line, and twelve on an oblique line from the ventrals to the base of the dorsal. The first rays of the dorsal and anal fins in both these species are neither flexible nor spinous, but bony. In classing them with the gudgeons, I have treated them as flexible, but should another observer consider them spinous, he will necessarily remove them to another genus. The fin rays of the two species do not differ from each other, more than individuals of each appear to differ among themselves; so that the fin rays will not serve to mark any specific difference.
D. 15 . P. 16 : V. 10 :
Gobio,
Cyprinus,
A. 7 : C. 19.
I' ${ }^{\circ}$ Clell.

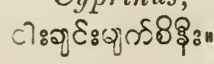
Buch.

\section{อง Oร $269 \mathrm{l}$.

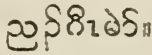

SMALL CYPRIN.

A small cyprin about five inches in length, is common in the interior. It is of a dark slate colour, with about sixty scales on the lateral line.
1. 16 : P. 16 : V. 8 :
A. 6 : C. 17 .
Cyprinida.

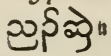

CHELA.

A fish of Buchannan's genus chela, and 11 'Clelland's opsarius, with the dorsal fin close to the caudal, and anal fin long, is not rare.

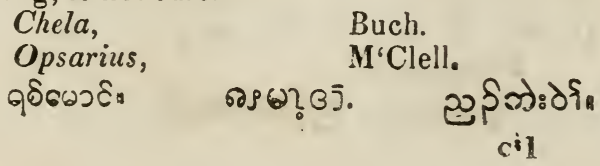


WHITE FISH.

A species of white fish is brought to the bazars in Maulmain, which has no barbules, and the dorsal fin is exactly over the interval between the ventral and anal. Its fin-formula dues not correspond exactly to any of the species described by $M^{\prime}$ Clelland.

D. $9:$ P. $14:$ V. $9:$ A. $12:$ C. 19.

Leuciscus.

Cी:0ืुष:

20. 3928

TAVOY WHITE FISH.

I have noticed a fish in the fresh-water streams of Tavoy, that resembles a species of

Lerciscus.

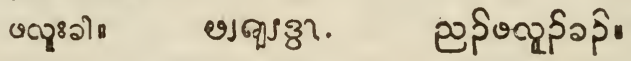

LOACH.

Two distinct species of loach in the mountain streams of the southern Provinces, I have seen, and there are probably others.

Cobitis.

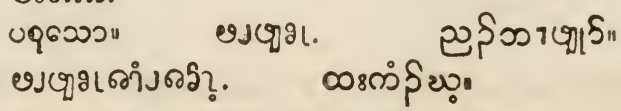

HERRING, PIKE, AND FLAT-FISH.

The herring, pike, and flat-fish tribes are represented by, flat-bellied herrings, thryssa-anchovies, Tenasserim. sardines bristle-finned sprats, shads, chatæsi, fresh-water herrings, flying-fish, half-billed gar-fish, pikes, plagusia soles, and brachirus-turbots.

FLAT-BELLIED HERRING.

A species of platygaster of the herring tribe, is often seen in bazar, which resembles the common herring. The mouth is entirely vertical, and the dorsal fin commences behind a very small ventral. The caudal fin is forked and yellowish, and the opercula are yellow. The fin rayz are,
$\begin{array}{llll}\text { D. } 14 \text { : P. } 13 \text { : } & \text { V. } 6 \text { : A. } 4: \text { C. } 20 \text {. }\end{array}$
Platygaster.
c]

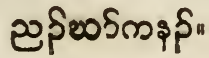




\section{THRYSSA-A NCHOVY.}

The genus thryssa, says Swainson, "has the general aspect of the anchovy, engraulis, but the body is broader, the mouth enormous, and opening almost vertical." The species then that inhabits our waters may be denominated the thryssa-anchovy.

Thryssa.

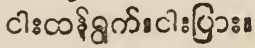

\section{BRISTLE-FINNED SPRAT.}

Another small fish of the herring tribe so much resembles the preceding, that the Burmese call it by the same name. It is, however, easily distinguished by a long filament or bristle, which is attached to each pectoral fin. Both species are often called sprats by Europeans, and they belong to the same tribe.

$$
\begin{aligned}
& \text { Setipinna. } \\
& \text { cी:ฮुว }
\end{aligned}
$$

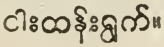

SARDINE.

There is a small fish of the herring family at Tavoy and Mergui, which 1 have not examined, but Dr. Morton thinks it is identical, or nearly related to the common sar dine, a fish of the same genus as the anchovy.

Engraulis meletta?

cी88\$8\$े००

MALAY SHAD.

$A$ fish of the herring family, with a deep notch in the upper jaw, characteristic of the genus alosa, abounds in the waters of Tavoy, and is often seen in the Maulmain bazars. It is called by the Burmese the Malay fish, and many being exported, dried, or salted from Tavoy, it has received at Maulmain the name of "the Tavoy fish."

D. $14:$ P. $15:$ V. $8:$ A. $23:$ C. 20.

Alosa.

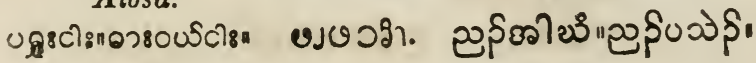




\section{RANGOON SHAD.}

Another species of shad is occasionally found in the estuary of the Salwen, which is said to be much more abundant near Rangoon.

\section{17 : P. 14 : V. 8 : A. 18 : C. 18. clะ006}

\section{CHATESUS.}

Some of the fish sold under the name of the Mialay shad, belong to the genus chatæsus, characterized by the last ray of the dorsal fin "prolonged into a lengthened filament."

\section{Chatasus.}

FRESH-WATER HERRING.

This species the Karens call the leaf-fish, from its shape. Swainscn says: "It has the general appearance of a herring, and is a rare Indian fresh-water fish, considered by Pallas as a gymnotus, but removed by Cuvier to the herring family." It grows much larger than a herring, and abounds in our streams.

Notoptcrus kapirat. clsouḱ!"
eschว่l.

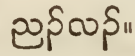

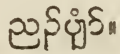

FLYING-FISII.

'The flying-fish is often seen fluttering above the waves off our coasts.

Exocctus. cา:ढิ\$"

\section{GAR-FISH.}

A handsome species of gar-fish inhabits our fresh-water streams, which in its colouring and general appearance, cannot be distinguished from the gar-fish of New England, but its fin-formula is materially different. It has light green upper parts approaching to silvery white beneath, and the caudal fin is truncated. The Karens call it the bird-fish, from its long bill.
D. 11: P. 9: V. 6:
A. $16:$ C. 17 .

\section{Belone.}

$$
\text { cी860าरक्षి }
$$

อ) 900 s.

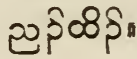




\section{HALF-BILLED GAR-FISH.}

In smooth weather at the mouth of our rivers, the water is sometimes seen almost covered with a curious gar-fish, whose upper mandible is very short, while the lower is as long as the ordinary gar-fish. Its snout forms a perfect counter-part to that of the scissors-bill.

Hemiramphus.

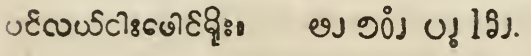

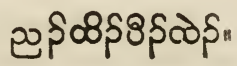

PIK E.

I have not met with pike in these Provinces, but it probably exists, for Capt. Phayre sent Dr. M'Clelland a species from Arracan, and $M^{\prime}$ Clelland wrote in his Journal : "We have been favoured by Lieut. Phayre with two fishes from Arracan, one a species of cyprinus from the Lemgoo river, the other a kind of pike." But I am not aware that it has been described.

Esox.

TENASSERIM SOLB.

A small fish of the sole family that grows to nine inches or a foot long, is sometimes seen in bazar. It has no pectoral fins, and the dorsal, caudal and ventral fins are united, so it is a species of plagusia. The natives think that two of them always swim together, with their flat, uncoloured sides united.

Plagusia.

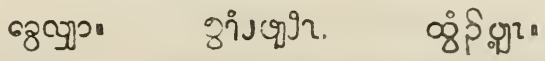

BRACHIRUS TURBOT.

A small flat fish with the aspect of the turbot, with two pectorals, the dorsal, caudal and anal united, and of a dark grey colour on the upper or right side, is sometimes in market.

Brachirus,

Swain.

cी868:09]ว:

องรู่าตต่า.

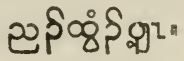




\section{CAT-FISE.}

The cat-fish, which Linnæus included in the single genus silurus, are very numerous in our waters. I have noticed more than thirty different species, and there are probably many others.

\section{ADIPOSB CAT-FISH.}

The cat-fish which are characterised by possessing a second adipose dorsal fin, are quite abundant. Two or three species are often called by the same native names.

Pimelodinc.

$$
\text { cीะ๐ई" }
$$

SHORT-HBADED CAT-FISII.

A large cat-fish with a comparatively short head, small second dorsal fiu, and a rather long anal, is often seen in bazar. It has two barbules on the upper jaw, and four on the lower.

Pimelodinc (Breviceps?) cา: दुध $\varepsilon_{811}$ esख़?
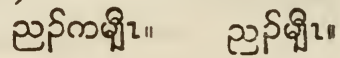

\section{BIGHT BARBULED CAT-FISH.}

A cat-fish about a cubit long, with two dorsal fins, and four cirri on the upper and four on the lower jaw, is not uncommon.

\section{Pimelodinc.}

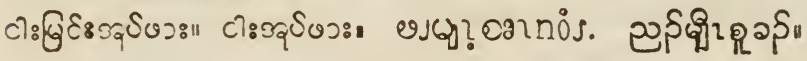

\section{MAILED CAT-FISII.}

A cat-fish with a long head, and mailed to the dorsal fin, is an inhabitant of our estuaries. It has strong spines in the dorsal and pectoral fins, which are serrated on the inner sides only, and resembles in its general appearance Pimclodus asperus. There are four cirri to the under jaw, and two to the upper, which are united by a membrane half their length to the head.

D. 1-6: P. 1-8: V. $6:$ A. $14:$ C. 16 (long rays.)

Pimelodina.

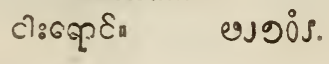




\section{SERRATE-SPINED CAT-FIgH.}

This fish resembles the preceding, but the head is less mailed, and the spines of the dorsal and pectoral fins are serrated on both sides. The cirri and fin-formula are the same, but the upper cirri are not united by a membrane to the head. The Burmese call both by the same name.

\section{Pimelodina. cी:6๑ว ह"}

LONG DORSAL-FINNED CAT-FISH.

Another common cat-fish belongs to the section of pimelodus, which has the adipose or second dorsal fin "of such considerable length as almost to fill up the interval between the first dorsal and the caudal, while it is very low at both extremities." The first soft ray of the dorsal fin is prolonged much beyond the others. The muzzle is narrow, rounded, and has four short cirri on the lower jaw and two on the upper, equalling the length of the whole body.

$$
\begin{aligned}
& \boldsymbol{P}_{\text {imelodina. }}
\end{aligned}
$$

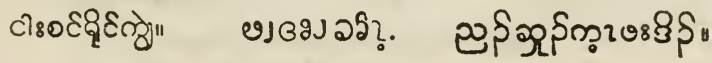

FRESI-WATER CAT-FISH.

A fresh-water cat-fish, a foot and a half long, of which I have only brief notes, belongs to the

Pimelodina.

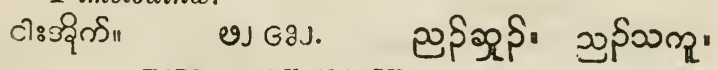

TOPSY-TURVEY FISH.

This is an odious looking, small, fresh-water hsh, with the general form of the river bull-head or miller's thumb, but it appears to be a cat-fish of the tribe with a second adipose dorsal fin. The ventral fins are placed far back under the second dorsal, the head is mailed, with four cirri on each jaw; the two on the upper one are very long, and two are very short. Its abdomen is enormous, as large as that of a sea-porcupine, and the natives say it always swims on its back, and hence they call it "the back-going fish."

Pimelodina.

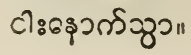

ขง ฆำ? 3?. 


\section{LARGE SILURE.}

The tribe of cat-fish characterized by the "tail and anal fin very long," contributes several species. One, which is said to grow as large as a man, has four cirri on the upper jaw and none on the lower; and the first ray of the dorsal fin is prolonged.

Silurus.

cी8uó.

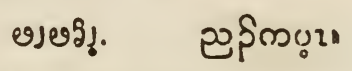

SMALL CAT-FISH.

A small cat-fish of the same tribe, has four cirri on the upper and four on the under jaw.
D. 1-5:
P. 1-5:
V. 6 :
A. 50 :
C. 18 .

\section{Silurus.}

cารฒำ.

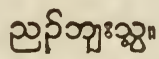

TWO-BARBULED SILURE.

A small fresh-water cat-fish, has only two cirri, resembling Lacepede's silure deux taches.

Silurus.

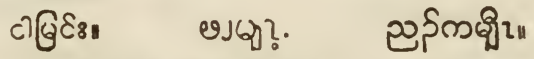

SMALL FRESH-WATER CAT-FISH.

A small fresh-water cat-fish of the genus silurus, from six to nine inches long, with strong spines on the pectoral fins, is very common.

Silurus.
cी:6rigg"
ง)
อุริ?"

FORK-TAILED CAT-FISH.

A small fresh-water silure, six inches long, with the caudal fins forked, is common.

Callichrus,
cา8ฐบวईะ॥
$\operatorname{ess} 09182$.

Buch.

\section{SILVERY CAT-FISH.}

A small pretty silvery cat-fish, with two long cirri to the upper jaw, is often brought to the bazars in Maulmain, which the natives call by the same names as the preceding.

Silurus,
cी:ฐพฺई81
$\operatorname{0jog182.~}$

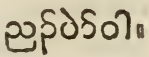


The Karens distinguish two allied species, which the Burmese call by the same name.

$$
\begin{aligned}
& \text { องชรเธอำรว่เ. }
\end{aligned}
$$

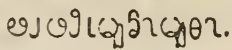

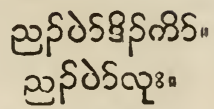

LARGE BARBULELESS CAT-FISH.

A large cat-fish found in the estuaries, with two dorsal fins and no cirri, is not rare. It is said to grow six feet long, and weigh more than a hundred pounds. There are two species that are called by the same name. One with wide truncated muzzle, the other with a pointed snout.

$$
\begin{aligned}
& \text { Ageniosus. }
\end{aligned}
$$

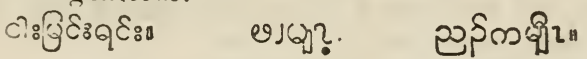

SMALL BARBULELESS CAT-FISH.

A small species of fresh-water cat-fish is also distinguished by being destitute of cirri.

$$
\text { Ageniosus. }
$$

PLOTOSUS CAT-FISH.

There are several species of cat-fish with the dorsal, caudal, and anal fins united, which are called by the same Burmese names, but the Karens distinguish three species. Plotosus.

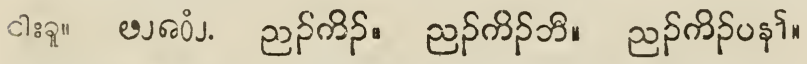

\section{CLARIAS CAT-FISH,}

This is a small fresh-water fish, that differs from all the preceding, by having the caudal fin distinct, characteristic of the genus clarias. The Burmese do not distinguish it from the preceding. A specimen that I sent Mr. Blyth he said was

$$
\begin{aligned}
& \text { Clarias magony. }
\end{aligned}
$$

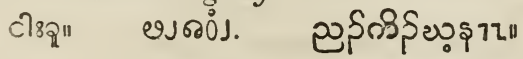

$$
\begin{aligned}
& \text { (Tavoy.) }
\end{aligned}
$$

LONG-HEADEN CAT-FISH.

A cat-fish with a prolonged flat head, the snout very broad, two barbules on the upper jaw which is longer than the lower, on which there are four barbules, is called cat-fish by the Burmese.

Sorubium.

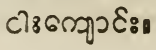

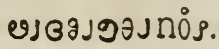


SMALL SORUBIUM.

A smaller species than the preceding, with the same generic chracteristic, is common, and other small species of pimelodince go by the same native names.
Sor ubium.

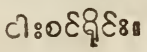
ชง ดรอร์?
బิ

SHARK-SNOUTED CAT-FISH.

This species has a long pointed cartilaginous snout, with the mouth opening below it like a small shark. It has two short cirri on the upper jaw, and four on the lower. There are two dorsal fins, and the dorsal and pectoral spines are serrated on both sides.

Sorubium.
cl:6९ุวर्ष
องรอํ.

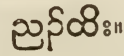

LARGE CAT-FISH.

A cat-fish which is sometimes six feet long and a foot wide, inhabits our estuaries.
cใฮู"
ององ.
已) $\left\{q q_{\text {n }}\right.$

OTHER CAT-FISH.

There are three or four other species, with distinet native names, which $I$ have not examined beyond ascertaining that they are cat-fish.
cl:จง8व्ठu์"
(a cured cat-fish in bazar.)
c) 8600 कर.
లుభ̊a
(a fresh-wnter fish.)

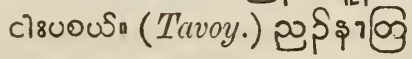
(an estuary species.)

\section{Cartilaginous Fish.}

We have no sturgeons among our cartilaginous fish, but the sharks and rays are very numerous, with one or more species of saw-fish, and torpedo.

SHARK.

Sharks are exceedingly numerous along the Coast. Between Tavoy and Mergui I have seen them gamboling 
around my boat by dozens. At Mergui, large quantities of shark's fins are exported by the Chinese as a delicacy. There are sereral species, but I have not studied them. Gigantic fossil teeth of a species of shark are found on the Arracan coast.

Squalus,

Linn.

cา80\$:11

อง 202.

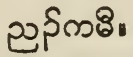

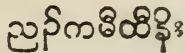

RHINEODON SHARK.

The natives describe to me a species like rhineodon, "with the mouih placed at the tip of the snout."

Rhineodon.

cी80ईุर्भि:

HAMMER-HEADED SHARK.

'The curious shark with a head like a hammer, accor: ding to an Englishman's imagination, but like a buffalo's horned-head, according to the Burmese, is also abundant.

Zygana.
cी:0ई:त्रो|

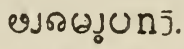

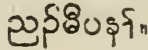

\section{SAW-FISH.}

A species of saw-fish, with its snout " produced into an osseous, flat, sword-shaped plate, armed with spines on the sides," frequents our waters. The bony snouts are sometimes seen two feet long, and are by some supposed to belong to the sword-fish.

Pristis.

c):osoरd.

องชอง 05.

SCATE.

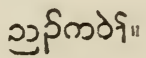

There are several species of scate or rays in our waters, and all, so far as I have observed them, belong to that section of the tribe that has the tail armed with serrated spines.

\section{Trigonina. cossmonis \\ ๓ะเบบ?}

\section{TORPEDO.}

The torpedo, or electrical fish, is said to be found on the Coast, but I have not met with it.

$$
\text { Torpedo? }
$$




\section{TORTOISE-FORMED FISEES.}

Of Swainson's order the Plectognathes, or tortoise-fornt. ed fishes, we have representatives, in the sea-porcupines, and the fishing frogs.

\section{FOUR-TOOTHED SEA-PORCUPINE.}

This is an odious looking fish, that has the power of inflating its abdomen to an enormous size, which compels it to turn on its back. It belongs to Linnæus' genus tetradon, so named from each jaw being divided into two parts so as to form four teeth ; and is called sea-porcupine, because several of the species are covered with spines. 'The species common off this Coast is perfectly smooth on the back, which is covered with bright, greenish-yellow spots, but the belly is inlaid with numerous small spines, like the thorns of a rose-tree. Authors who restrict the sea-porcupines to ihe genus diodon, would call this species square fish. It is nearly related to the American toad fish, which is deemed poisonous, but our fish is eaten by the poorer natives. The fin rays are,

D. 10: P. 16: A 10: C. 7 .

Lagocephalus,

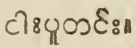
es $395000 \mathrm{~s}$.

Swain.

SMOOTH SEA-PORCCPINE.

The natives inform me that there is a smaller species than the preceding, which $I$ have not seen, in which the abdomen as well as the back is perfectly smooth.

Lisomus,?

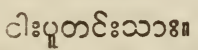

\section{อง $39100 ำ 00$ ง.}

Swain.

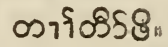

\section{FISHING FROG.}

An ugly little fish resembling a species of lophius, the angler, fishing frog, or sea devil, which I have not examined, frequents our Coast.

\section{Lophius?}

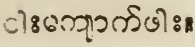

ขjอง?. 


\section{EEL TRIBE.}

The cels are not numerous in individuals, but in these Provinces, and in Arracan there have been found nine or ten species.

\section{COMMON EEL.}

The eel most usually seen in bazar, which belongs to the genus anguilla, with pectoral fins, is identical with a species described by Dr. M'Clelland, from Arracan, of which " the colour above is dark olive-green or brown, and white beneath."

$$
\begin{aligned}
& \text { Anguilla bicolor. } \\
& \text { cl8coरuई口 } \\
& \text { อง รวำ. } \\
& \text { ชิ }\left\{\infty^{\circ}\right.
\end{aligned}
$$

OTIER COMMON EELS.

The natives describe another species resembling the above, but for which they have no distinctive name. It is probably one of three other species that inhabit Arraean, two of which, Capt. Phayre sent Dr. M'Clelland from Sandoway.

$$
\begin{gathered}
\text { Anguilla arracana. } \\
\text { " } \quad \text { ncbuirostris. } \\
\text { nculos. }
\end{gathered}
$$

MURANA EEL.

Of the eels belonging to the Linnean genus murana, Dr. Al'Clelland received specimens of one species from Sandoway.

Tharodontis reticulatu.

$\mathrm{M}^{`} \mathrm{Clell}$.

SERPENT-HEAIREI) EEL.

There is a peculiar tribe of eels in India which are characterized by having the heart far back in the body, like a serpent, and not near the gills, as in ordinary eels. Their general appearance too is more that of a snake than an eel, but a large opening for the gills under the throat proves at a glance that it is a fish and not a serpent. The present species was first described by Buchannan, who said it had neither fins nor scales; and this is the first 
impression, but on closer examination it will be found to have scales, and narrow fringes may be seen near the tail, representing the dorsal and anal fins. It corresponds in all important respects with M'Clelland's description of $\boldsymbol{P}$. striatus, but the tail is rather shorter; there are no black spots on the back, and the under parts are orange-white, interspersed with dark patches or spots, of the same olive-green colour as the back.

Pneumabranchus striatus,

Unibranchapcrtura cuchia,

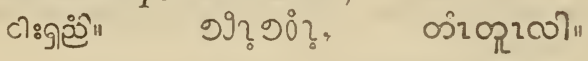

M'Clell.

Buchan.

PHAYRE'S SERPENT-YEARTED EEL.

This is a new species, more typical of the tribe than the preceding, and may be regarded as the serpent-hearted eel par excellence. Dr. M'Clelland received his specimens from Capt. Phayre of Arracan, and named the species after him. I have not identified the fish in these Provinces; but there is an eel which the natives say differs from the preceding in having a shorter head and being destitute of scales, which shows that it is either this species, or a species of ophisternon. To assist in the identification of this rare and curious species, I insert M'Clelland's description in full.

"In this singular species the intestinal aperture is placed at the posterior fifth of the length. The head is short, raised and round, larger in diameter than the body, the adjoining portion of which is, towards the head, augmented; the jaws are depressed, the upper jaw is rather more prominent than the lower, the muzzle is rounded, having two short tubular nostrils at the extremity. "The body is not compressed, but is slightly conical from the head to near the verit; the tail from thence becomes much compressed and very narrow. The tail is emarginated with an adipose duplicature of the skin like the blade of an oar.

"The outer band of teeth on the upper jaw expands in front on either side, without meeting the opposite corresponding band, thus leaving a narrow vacant space at the apex. 'There are three strong branchial arclies; 
with slight fleshy very short pectinated gills, like the teeth of a saw.

"There are five branchial rays on each side, the first larger and stronger than the others, and isolated from them, standing considerably in front. The branchial rays are strong and bony.

"There are no scales distinguishable in the skin, even with the microscope.

"The colour above is dusky-brown, minutely dotted with brownish black, the lower parts are of a somewhat lighter shade.

"The length of the specimen is about 20 inches.

"The stomach is an expansion of the csophagus into a long spindle-shaped, wide tube, tapering equally at either end, and contracting gradually behind into narrow intestine, which again gradually expands almost to the size of the stomach; the whole, including the œsophagus being one continuous straight tube. There seems to be no pyloric valve, the contraction of the first portion of the intestine answering the purpose of one."

Ophicardia Phayreana.

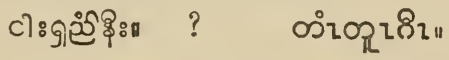

SERPENT-TRUNKED EEL.

Another eel from Arracan M'Clelland placed in his new genus ophisternon.

Ophisternon hepaticus.

CONGER EEL.

M'Clelland says there are no proper conger eels in India, the species that was referred to that genus by Buchannan, forming the type of a new genus, which he has named murænesox, the species of which he says, "occupy an equivalent place in the East, with the congers of the Western world." There are probably several species on the Coast. Captain Lloyd met with one four feet long off the islands on the Arracan coast.

Murcenesox cxodentala.

c)8 005350070 ก॥ 
OTHER SEA-EELS.

'There are several other species of sea-eels but $\mathbf{I}$ have not investigated them. The natives regard them all as related to the pelagic snakes, and some say their bite is poisonous, though not fatal.

Karens in the delta of the Irrawaddy distinguish several species.

Murøencsox.?

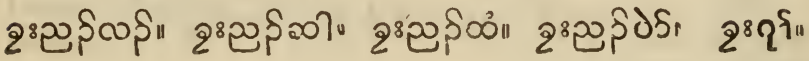




\section{ADVERTISEMENT.}

\section{Iit the Press, and shorlly will be published,}

\section{AN A P PENDIX}

TO THE PRECEDING WORK.

The author has not gone over all the ground he contemplated, but he has much exceeded the limits which he had originally marked out for himself, in the size of the book that he proposed to furnish at the subscription price. He had therefore to choose between making the latter part of the work a mere catalogue, which would be to make it comparatively valueless, or to treat the subjects in a manner uniform with each other, and close the work at the end of Ichthyologg. After consulting some of the subscribers most interested in the work, he has chosen the latter alternative, but any subscriber who $m$ ay be dissatisfied with this arrangment, will not be considered under any obligation to receive the copies for which he has subscribed.

The writer proposes to publish the remainder of his notes in the form of an Appendix, which will treat on Reptiles, Insects, Shells, and the Native Tribes. Systematic Catalogues will be added of the Minerals, Plants, Mammalia, Birds, Fishes, Reptiles, Insects, and Shells; and alphabetical indexes of the English, systematic', Burman, and Karen names that occur in the work. 


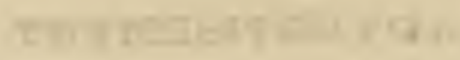





\section{New York Botanical Garden Library}

QH183.M38

Mason, Francis/The natural productions o

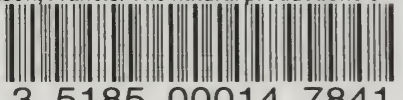

35185000147841 


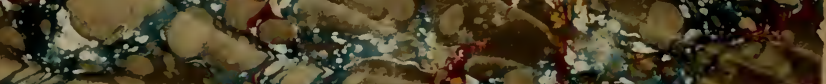

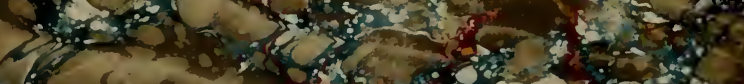

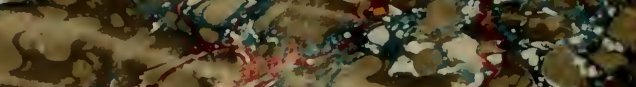

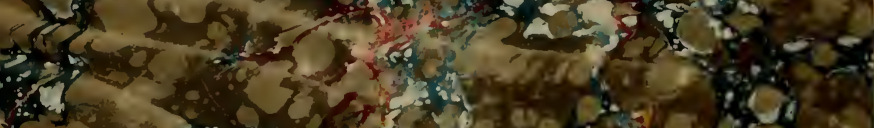

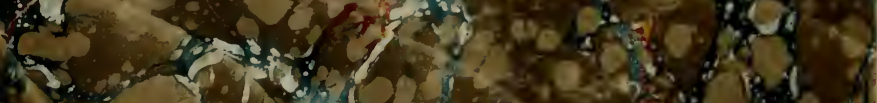
19.

42 a

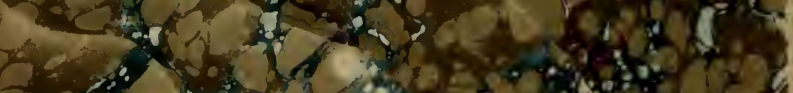

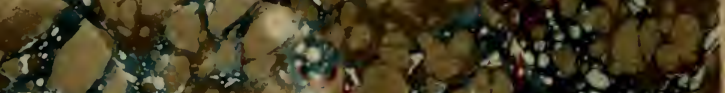

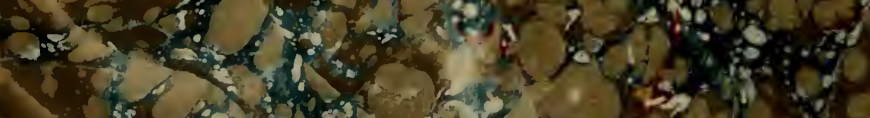

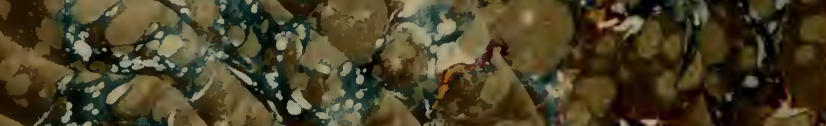

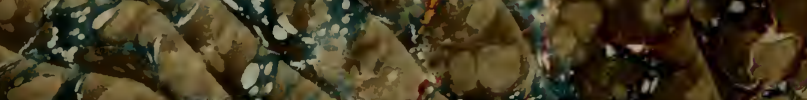

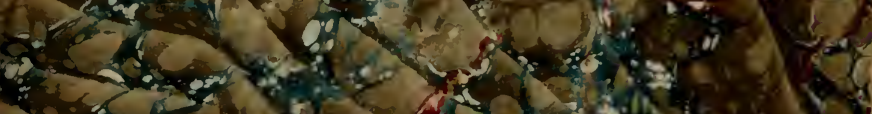

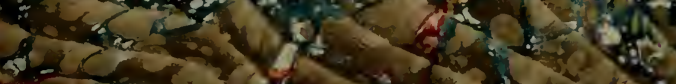

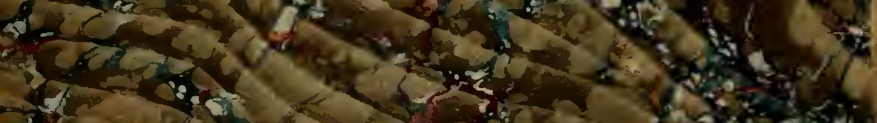

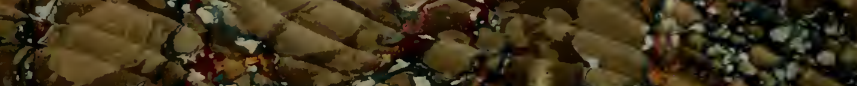

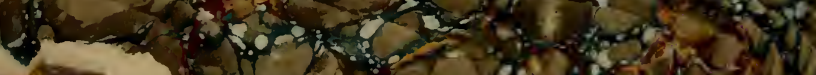

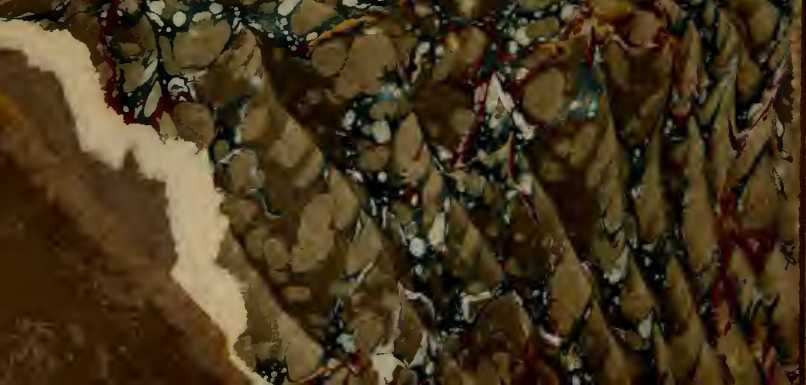

